UNIVERSIDAD NACIONAL DE LA PLATA

FACULTAD DE HUMANIDADES Y CIENCIAS DE LA

EDUCACIÓN

SECRETARÍA DE POSTRADO

MAESTRÍA EN LINGÜÍSTICA

\title{
DESDE EL PÚLPITO: UN ANÁLISIS DESDE LAS TEORÍAS DEL GÉNERO Y LA VALORACIÓN DE HOMILÍAS DE LAS MISAS DE TEDEUM DEL 25 DE MAYO EN LA ARGENTINA (1976-2010).
}

Cristina Inés HERAS

Directora: Dra. Luisa GRANATO

Año: 2012

Tesis presentada como requisito para la obtención del grado de Magíster. 


\section{AGRADECIMIENTOS}

En la realización de este trabajo hubo muchas personas que me ofrecieron su valiosa ayuda. Quisiera en primer lugar agradecer todo el apoyo, conocimiento y confianza que recibí de Luisa Granato, mi directora de tesis, quien fomentó en mí el interés por esta tarea fascinante, que supo esperarme cuando el trabajo no parecía tomar la forma deseada u otros intereses se interponían en la ardua tarea de escribir e intentar generar nuevos conocimientos y que también supo acompañarme desde la calidez que transmite en su permanente preocupación por el otro, su comprensión y, por sobre todas las cosas, su particular sentido del humor. A ella también le reconozco y agradezco el constante impulso a encarar la observación respetando la libertad y creatividad con las que estamos naturalmente dotados y a las que tanto tememos.

Les debo también un sentido agradecimiento a María Marta García Negroni quien empezó la dirección de mi tesis original que derivó después de unos años a otras vertientes de la lingüística; a Adriana Bolívar, quien también me dedicó parte de su valioso tiempo pero la distancia impidió que la tarea pudiera llevarse a cabo. A Tomás Grigera que me leyó con entusiasmo y asombro brindándome su sabia visión de las cosas y alentándome de un modo muy original cuando todo parecía estancarse. A los profesores de la Maestría que tanto me enriquecieron en lo personal y en la tarea docente. $Y$ muy especialmente a mi familia, a mis hijos que se vieron obligados a compartir a su madre con esta tesis durante años cruciales de sus vidas, a mis padres que cuidaron de ellos y al hacerlo también cuidaban de mí, a quien me dio la idea de embarcarme en esta aventura, a quien me acompaña en este tramo de mi camino, a quienes me dieron aliento cuando la voluntad flaqueaba e incluso a aquellos que me sugirieron dejar todo. Todas esas voces dispares, lejos de confundirme me ayudaron a escuchar esta voz interna que finalmente me alentó a concluir esta empresa que llevó mucho más tiempo de lo que habría deseado. 


\section{Índice}

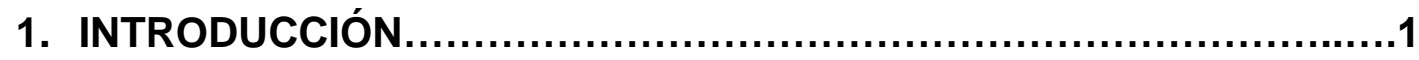

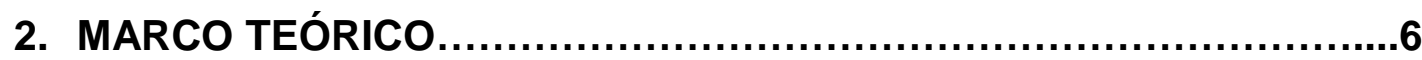

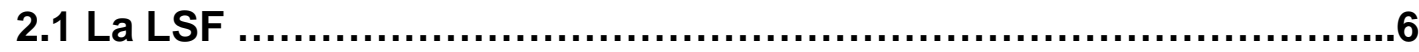

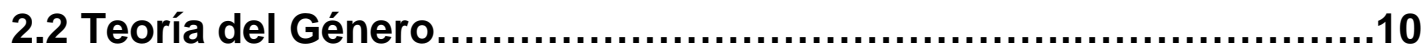

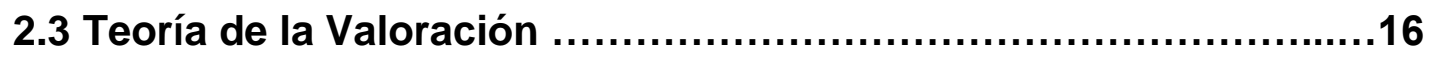

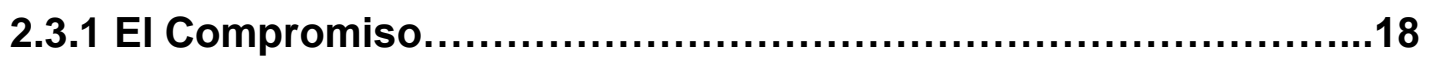

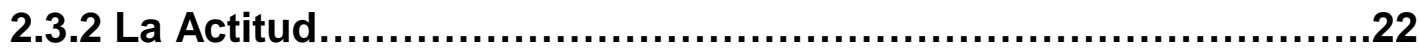

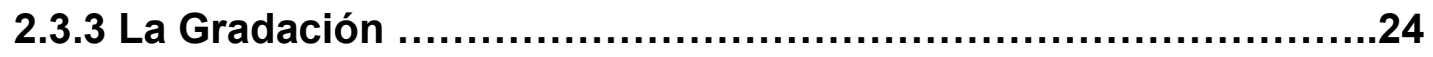

2.4 Estado de la Cuestión ........................................................ 26

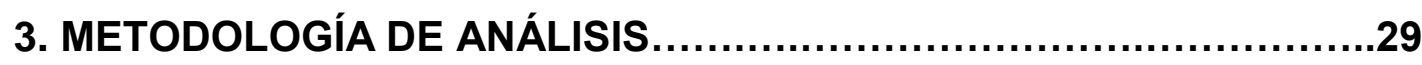

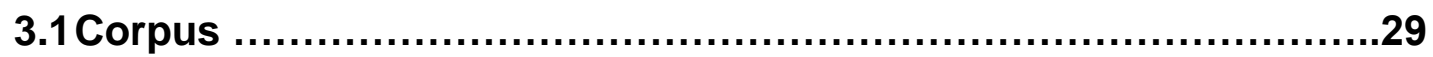

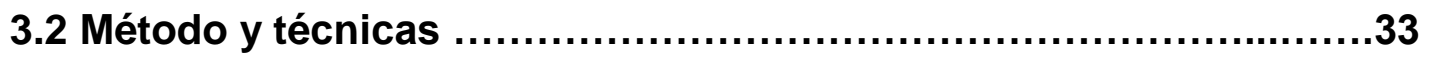

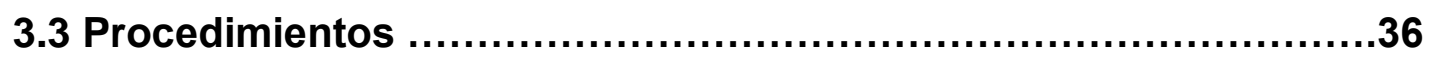

4. EL ESTUDIO …..............................................................

4.1. La homilía de Tedeum del 25 de mayo: su función social...........43

4.1.1 Valor comunicativo y funcional de la homilía de Tedeum..........45

4.2 Etapas constitutivas ....................................................... 54

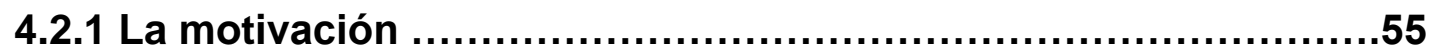

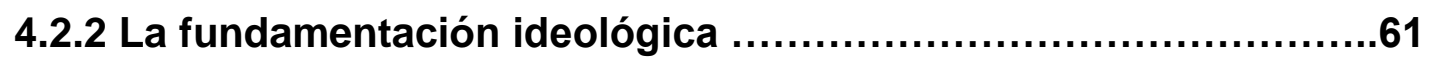

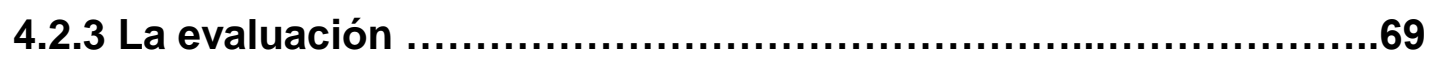

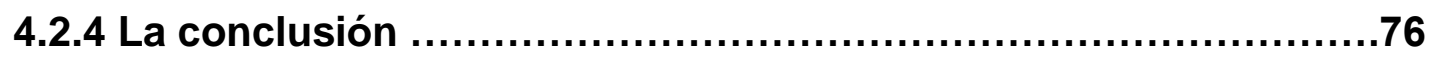

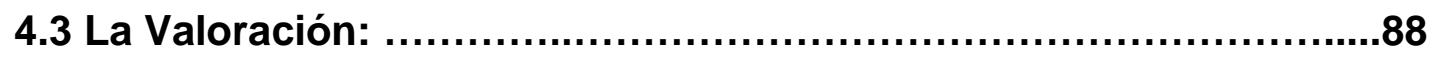

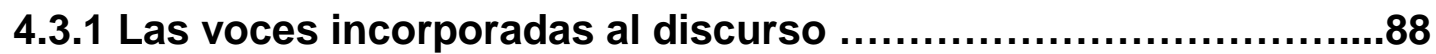

4.3.2 El emisor frente a su audiencia (heteroglosia y monoglosia).....100

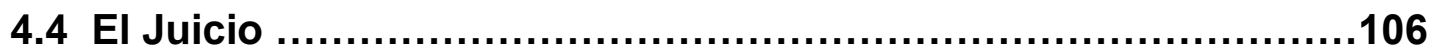

5. CONCLUSIONES ..........................................................121

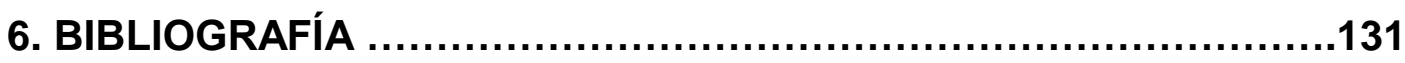

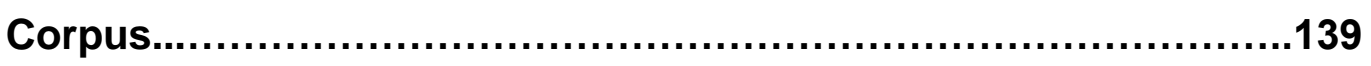




\section{INTRODUCCIÓN}

...We don' believe that ideational meanings simply translate a pre-existing "reality" into words; rather speakers and writers construe their experience of reality as discourse. ${ }^{1}$

Martin E Rose, 2003: 66

\section{La celebración del Tedeum y sus homilías.}

Las creencias religiosas forman parte esencial de la cultura de un grupo y las prácticas del mismo son importantes para la construcción de la identidad. Según Dürkheim (2001:360), "con los ritos, el grupo social se reafirma periódicamente. A través de ellos, los hombres se sienten unidos, además de por lazos de sangre, por una comunidad de intereses y de tradiciones y adquieren conciencia de la unidad moral".

La celebración del Tedeum es un canto de alabanza y de acción de gracias dirigido a Dios por su amor misericordioso. Este antiguo himno hunde sus raíces en una tradición de la Iglesia de más de 1600 años y de los pueblos cristianos. Utilizado en las ceremonias litúrgicas y en innumerables acontecimientos civiles, ha estado siempre presente en la vida de la Iglesia y de los pueblos a lo largo de los siglos, como así también de nuestra propia historia. Es considerada parte de las celebraciones patrias y ha marcado los hitos fundamentales de nuestra historia como Nación, razón por la cual no se discute que constituya parte de la tradición e idiosincrasia del pueblo argentino. $^{2}$

\section{Las tres dimensiones básicas de la predicación}

Maldonado (1993) señala que dentro del amplio espectro que ofrece la pastoral profética, hay que distinguir diversos géneros de predicación de la palabra de Dios. Básicamente, la Iglesia toma tres: la evangelización, la catequesis y la

\footnotetext{
${ }^{1}$ No creemos que los significados ideacionales simplemente traduzcan una "realidad" preexistente en palabras; más bien los hablantes y escritores construyen su experiencia de la realidad como discurso.

${ }^{2}$ Mons. Taussig (2010) "El Te Deum y la patria" Intervención en la Inauguración de la XXXV SEMANA TOMISTA -Congreso Internacional, sobre el tema PATRIA Y BIEN COMÚN Reflexiones en el Bicentenario 2010-2016, Buenos Aires, 13 de septiembre de 2010.
} 
homilía que forman un proceso unitario y sucesivo. La evangelización se refiere al primer anuncio de la Buena Nueva, la catequesis sistematiza y profundiza lo que se anunció en la evangelización; es una dimensión más didáctica de la predicación por la que se van presentando por partes los contenidos del mensaje. Finalmente, la homilía es la comunicación de la Buena Nueva dentro de la celebración litúrgica, que es su ámbito propio. La misma tiene como propósito que lo que se cree ya globalmente en la evangelización y se va entendiendo en profundidad en la catequesis, vaya calando en la mentalidad de los fieles y se lleve a la práctica en la vida, siguiendo el mensaje de las lecturas escuchadas en la celebración. Además de concebirse dentro de la celebración litúrgica, la homilía va dirigida no solo a la comunidad religiosa sino también a todos aquellos que busquen la superación personal y espiritual. Tiene como base, en la mayoría de los casos, las lecturas bíblicas escogidas para la celebración y como meta la interpretación que busca trasladar su contenido a las prácticas de vida, siguiendo el estilo de conducta que marca la Palabra de Dios. Es una exhortación que hace el ministro ordenado que preside la celebración acerca de la conveniencia de obedecer a los postulados de la doctrina cristiana presentándole el modelo a seguir. ${ }^{3}$

La Conferencia Episcopal Argentina cuenta con una gran variedad de géneros discursivos que se publican en forma escrita para dar a conocer la postura de la Iglesia frente a acontecimientos ocurridos tanto en el ámbito de lo civil como de lo religioso. Entre ellos, podemos mencionar las declaraciones, comunicados, cartas políticas, mensajes, documentos y las homilías, siendo estas últimas objeto de estudio en el presente trabajo.

Según lo define Mons. Marino, "la homilética constituye una de las formas más frecuentes y eficaces para el magisterio de un obispo, con una finalidad catequética y exhortativa, que en estas ocasiones han buscado aportar una luz orientadora en los múltiples problemas que se originan en la convivencia

\footnotetext{
${ }^{3}$ Luis Maldonado (1993)
} 
ciudadana, en la búsqueda del bien común y del recto ordenamiento de la vida social."4

Según lo expuesto, los aspectos definitorios de las homilías, podrían resumirse en, por un lado, su función didáctica y, por otro, su función exhortativa. Sin embargo, no refieren solo a temas de índole puramente religioso o teológico sino que en ellas se abordan problemas relacionados con la vida en sociedad. En la mayoría de los textos se hace alusión a los hechos históricos que se rememoran, al contexto histórico y político del momento en que se emite y también, aunque no en todos los casos, se hace una evaluación de las personas y acontecimientos. La temática abordada así como las decisiones de posicionamiento que toma el emisor frente a su audiencia hacen que los textos que componen el corpus de nuestro estudio sean sumamente interesantes para su análisis desde la perspectiva de la Lingüística Sistémico Funcional (en adelante, LSF), los estudios de género y la Teoría de la Valoración específicamente.

Nuestro objeto de estudio será, entonces, el discurso de las homilías de misas de Tedeum de 25 de mayo con presencia de las autoridades nacionales. En el presente trabajo se recopilan dieciocho homilías emitidas en un período de 34 años (1976/2010) en el que el país pasó por un golpe militar en el año 1976, la dictadura de las juntas que se fueron sucediendo a lo largo de siete años hasta finales del año 1983 y el posterior proceso de transición a la democracia y su consolidación hasta el año 2010.

Parte del análisis consistirá, entonces, en la observación de los rasgos que constituyen estos textos como especímenes de un mismo género discursivo teniendo en cuenta el posicionamiento del locutor frente a una audiencia que puede ubicarse en un espacio tanto antagónico como solidario, según el momento en que la celebración del Tedeum haya tenido lugar.

\footnotetext{
${ }^{4}$ Palabras de S.E.R. Mons. Antonio Marino, Obispo auxiliar de La Plata, en la presentación de la obra en la Feria del Libro de Buenos Aires, el pasado 9 de mayo de 2010.)
} 


\section{Las preguntas}

La lectura reiterada de los textos a analizar nos lleva a plantear los siguientes interrogantes:

- ¿Qué lugar pueden ocupar las homilías de Tedeum dentro de los discursos institucionales que se producen en nuestra cultura?

- ¿Constituye la homilía de Tedeum de 25 de mayo ante autoridades nacionales un género discursivo?

- ¿Qué función social cumplen las homilías de Tedeum de 25 de mayo en los niveles global y local?

- ¿Qué marcas deja el nivel léxico-gramatical en la construcción discursiva de los textos?

- ¿Cómo se introducen las voces externas al texto actual?

- ¿Qué recursos evaluativos se encontraron en los textos? ¿Cómo dan cuenta del posicionamiento del emisor frente a los actores y eventos evaluados?

\section{Objetivos.}

Siguiendo, entonces, los lineamientos planteados, proponemos el siguiente objetivo general:

(i) Definir y analizar las características salientes de los textos en estudio.

Mientras que los objetivos específicos de este trabajo son:

(i) identificar y caracterizar el marco institucional y los actores que participan en la producción de los textos.

(ii) Identificar las etapas que constituyen la secuencia típica de realización de las homilías de misas de Tedeum para determinar si los textos pueden constituir un género discursivo.

(iii) Identificar y describir la función global y las funciones específicas de cada una de las etapas constitutivas de los textos.

(iv) Identificar y caracterizar aspectos evaluativos salientes del discurso. 
Las hipótesis que subyacen a los propósitos señalados son las que se formulan a continuación:

(i) Las homilías de Tedeum de 25 de mayo constituyen un género discursivo que puede analizarse desde un punto de vista sistémicofuncional.

(ii) El discurso está construido mediante la inclusión de voces por parte del emisor quien pone de manifiesto qué tipo de relación mantiene con ellas, y cómo desea que esta relación sea percibida por la audiencia.

(iii) El locutor asume un compromiso respecto de su discurso y, a la vez, toma un posicionamiento frente a la audiencia que construye desde el consenso o el disenso.

(iv) El sistema de Juicio está constreñido por la situación particular en la que opera. El modo en que los emisores evalúan en su discurso la conducta humana, está determinado por la situación cultural e ideológica en la que se emiten los textos estudiados

Para lograr los objetivos propuestos, esta tesis se compone, además de esta introducción, de cinco capítulos: un primer capítulo en el que se expone y se procura justificar la elección del marco teórico; un segundo capítulo en el que se presenta el propósito de la tesis en mayor detalle y se lo formula tomando en cuenta las categorías descriptas en el capítulo previo; un cuarto capítulo, en el que se lleva a cabo el estudio del corpus; y un capítulo final en el que se formulan las conclusiones y comentarios finales. 


\section{MARCO TEÓRICO Y ESTADO DE LA CUESTIÓN}

En esta sección se hará una breve descripción del modelo general de la lengua que propone la Lingüística Sistémico Funcional (LSF) y una descripción más detallada del estudio de los géneros y la Teoría de la Valoración (Appraisal Theory) que se encuadran dentro de esta misma vertiente. Con la descripción de la LSF se espera contextualizar el estudio de género así como las evaluaciones en forma más acabada. Asimismo, se procura en esta sección justificar la elección de la LSF como marco teórico fundamental del análisis. Finalmente haremos referencia a la los estudios realizados sobre el tema.

\subsection{La Lingüística Sistémico Funcional}

La LSF concibe la lengua como un recurso multifuncional y estratificado (Matthiessen 1995:1-3). Este modelo entiende que cada estrato es parte de una red de sistemas o paradigmas interconectados (Matthiessen 1995:10-17) y que la relación entre estratos es una relación de realización en la que los significados o metafunciones realizan dimensiones contextuales, es decir, configuraciones situacionales específicas de campo, tenor y modo del texto, los cuales, a su vez, son realizados por los sistemas que conforman el estrato léxico- gramatical. Como se puede apreciar, la LSF (Eggins 1994, Halliday 1994, Halliday \& Martin 1996, Martin 1992, Matthiessen 1995 Thompson 1996, Martin y White 2005 entre otros) es un enfoque semántico y funcional de la lengua concebida como un recurso para fabricar significados. Los analistas que se adhieren a este abordaje distinguen tres tipos de significados que los hablantes construyen y que se dan en forma simultánea en todos los niveles gramaticales. Éstos son. (i) el significado ideacional que incluye el significado experiencial o significado sobre el mundo externo o interno al sujeto así como el significado sobre las relaciones lógicas en el mundo; (ii) el significado interpersonal que tiene que ver con las relaciones entre los participantes en una interacción y la actitud del hablante; y (iii) el significado textual o significado sobre el texto que se produce en una situación de interacción. Los significados están íntimamente vinculados con el contexto de situación, o sea con el 
contexto inmediato de producción del texto que Halliday define como "el entorno en el cual se intercambian los significados" ${ }^{5}$ (Halliday \& Hasan 1980:12). Asimismo, Halliday (1978) afirma que un modelo de lenguaje de este tipo puede relacionarse "en forma natural" con la organización del contexto, usando el significado ideacional para construir el campo (la acción social), el significado interpersonal para gestionar el tenor (estructura del rol) y el significado textual para desarrollar el modo (organización simbólica). Esta relación se describe en la figura 1 que grafica las metafunciones en el modelo contextual de lenguaje (círculo interno) en relación con el contexto social (círculo externo). Eggins y Martin (2003).

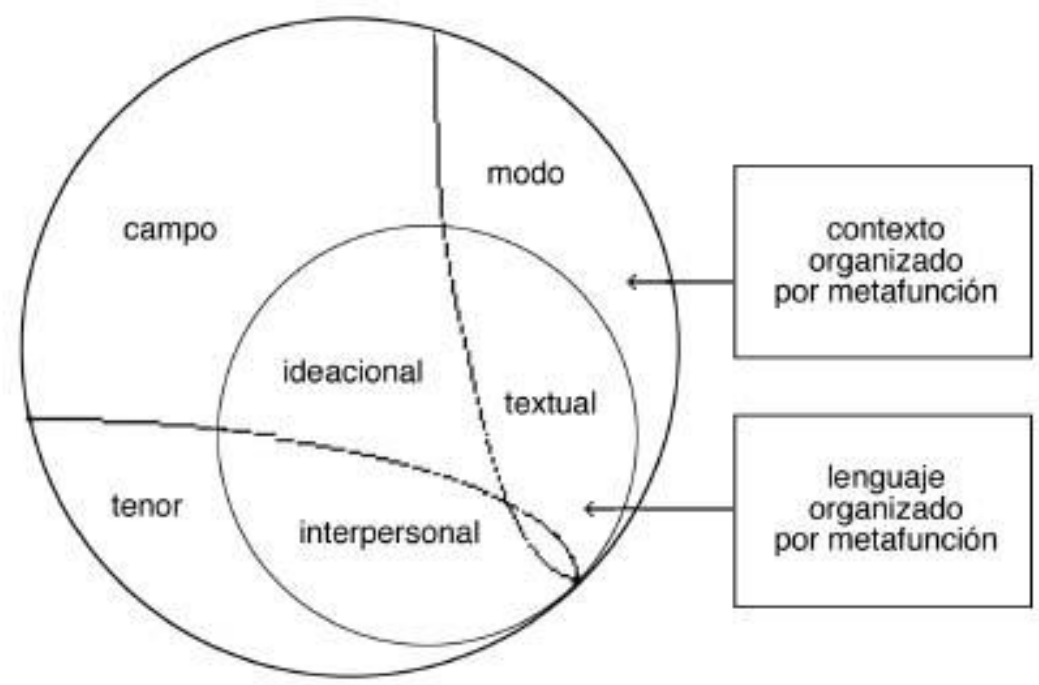

Gráfico 2. 1: Modelo estratificado del lenguaje en contexto Eggins y Martin (2003): 191

\section{El contexto}

Como ya dijimos, una teoría funcional del lenguaje busca establecer una relación entre el contexto y el texto. Desde esta perspectiva, entendemos que al abordar un texto para su análisis no podemos aislarlo de su contexto situacional, institucional, histórico, social, cognitivo, político que le sirve de

\footnotetext{
${ }^{5} \mathrm{Mi}$ traducción del original "the environment in which meanings are being exchanged"
} 
sustento. Sin embargo, "la realización de los significados en contexto a través del texto no es directa ya que la relación que se establece entre ambos es probabilística y no determinista y la posibilidad de alternativas es inherente a la relación dialógica entre lenguaje y contexto" (Eggins y Martin 1997:236).

El origen de la incorporación de la noción de contexto de situación a la teoría lingüística se remonta a la Escuela Lingüística de Praga (1929/1939) y a lo que se denominó "el contextualismo británico" cuyo referente más importante fue Firth (1957). Para elaborar su teoría, este autor se basó en las nociones de "contexto cultural" y "contexto de situación" propuestas por Malinowski (1923) y reelaboró el concepto de "contexto de situación", adecuándolo y precisándolo para el ámbito de la lingüística. Para Malinowski (1923, 1935), el contexto incluía el "contexto de situación" más inmediato del enunciado y el "contexto de cultura" más global. En este aspecto, la LSF, además, reconoce la influencia del trabajo de Hymes (1967) sobre etnografía de la comunicación (Halliday \& Hasan, 1989). La idea de una relación entre contexto y texto fue formalizada por primera vez en el concepto de registro el cual era considerado como "una variedad de acuerdo al uso en el sentido de que cada hablante tiene un espectro de variedades y elige entre ellas en diferentes momentos" ${ }^{6}$ (Halliday et al. 1964).

La LSF adopta una perspectiva socio-semántica de la lengua y bajo esta perspectiva, la lengua se entiende como un sistema semiótico que realiza y manifiesta las estructuras que conforman una sociedad y una cultura determinadas. No se trata de una visión determinista sino que lengua y contexto se determinan bi-direccionalmente (Halliday \& Hasan 1980:55; Halliday \& Martin 1993:24). El propio marco de análisis presenta una teoría sólida sobre el contexto. De hecho, la LSF describe tres estratos en el contexto: la situación (perspectiva lingüística), la cultura y la ideología (perspectiva social y, por lo tanto, más abstractos) (Martin 1992: 494-495). Si bien son muchos los autores que se han referido al concepto de cultura, dentro del enfoque de la Sistémica, el contexto de cultura se concibe como "un sistema de procesos

\footnotetext{
${ }^{6}$ Mi traducción del original en inglés: ... a variety according to use in the sense that each speaker has a range of varieties an chooses between them at different times.
} 
sociales" (Martin 1992:494). Los procesos sociales a los que hace referencia Martin (1992) son actividades culturalmente pautadas, que se realizan lingüísticamente y es a estas realizaciones que se las denomina géneros, objeto de estudio de la Teoría de Géneros desarrollada dentro del mismo marco teórico. En este sentido, Spencer-Oatey (2000), luego de incursionar en las definiciones del concepto de cultura a lo largo de la historia y de concluir que no hay acuerdo entre los antropólogos acerca de su naturaleza, propone la siguiente formulación:

Una cultura es un conjunto difuso de actitudes, creencias, convenciones de comportamiento, suposiciones básicas y valores compartidos por un grupo de personas, y que influye sobre la conducta de cada miembro y las interpretaciones que cada miembro hace de los significados de la conducta de los otros. ${ }^{7}$

Según esta definición, la cultura se manifiesta en diferentes estratos partiendo en su nivel más profundo con los valores y las suposiciones básicas, pasando por los niveles de las actitudes, creencias y convenciones sociales para finalmente llegar al nivel más superficial expresado en las manifestaciones conductuales. Lo que la autora comparte con la idea de contexto adoptada por los autores de la LSF es que el concepto de cultura se conforma tomando aspectos que influyen tanto en la conducta como en los significados que la gente atribuye a la conducta de los otros. Asimismo, se concibe a la cultura como un concepto "difuso" ya que es poco probable que los miembros de un grupo compartan actitudes, creencias o valores idénticos puesto que no hay un conjunto de características que pueda diferenciar en forma categórica y fehaciente un grupo social de otro. En el siguiente diagrama, Spencer-Oatey adapta el concepto de las manifestaciones de la cultura en diferentes capas de profundidad de G. Hofstede, Cultures and Organizations, New York: McGrawHill 1991, y Trompenaars y C. Hampden-Turner, Riding the Waves of Culture, London: Nicholas Brealey, 1997.

\footnotetext{
${ }^{7}$ Mi traducción del inglés: Culture is a fuzzy set of attitudes, beliefs, bahavioural conventions, and basic assumptions and values that are shared by a group of people, and that influence each member's bahaviour and each member's interpretations of the "meaning" of other people's bahaviour.(SpencerOatey 2000:4)
} 


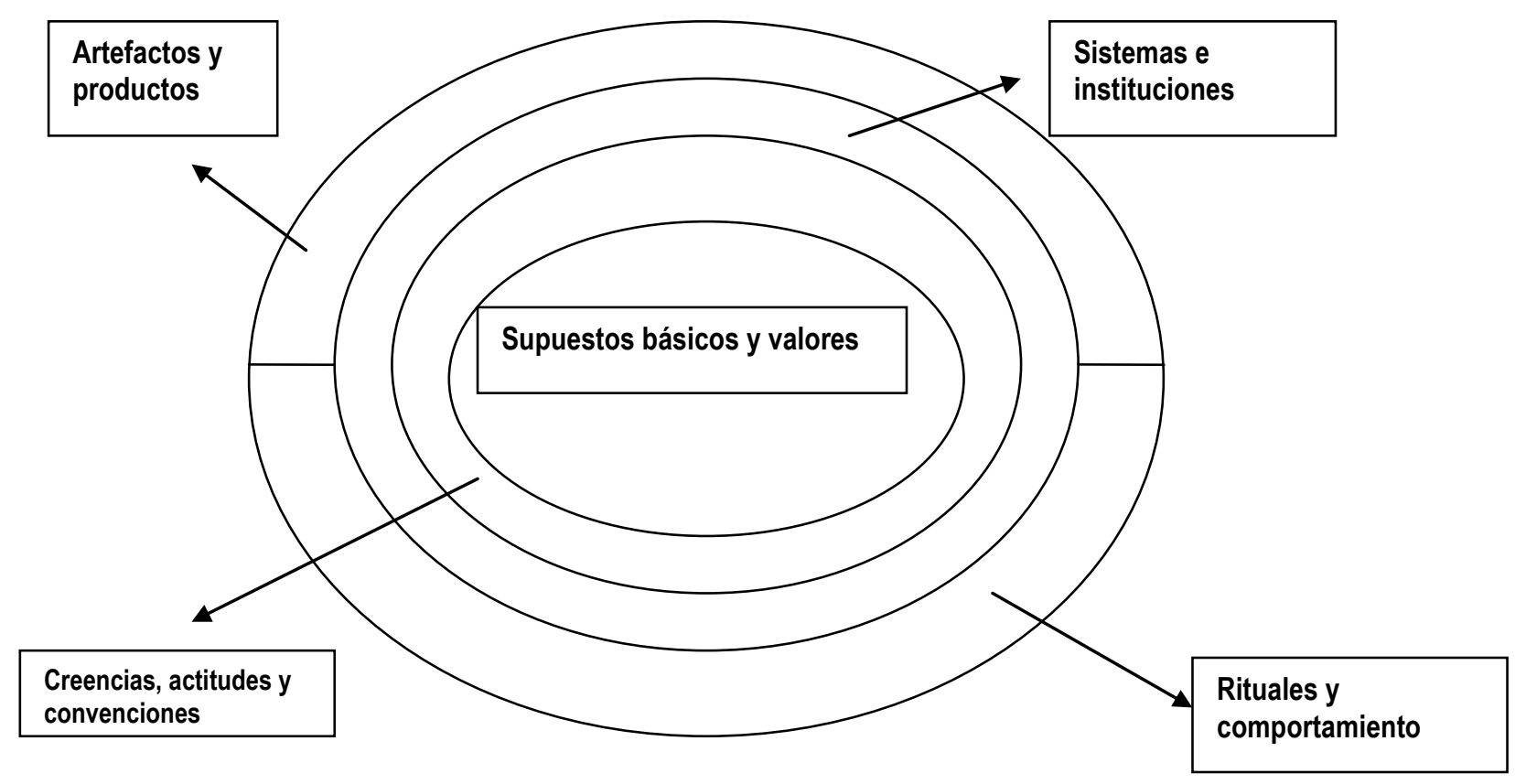

Gráfico 2. 2: Manifestaciones de la cultura en diferentes capas de profundidad. (Spencer- Oatey (2000) : 5.

Finalmente, la autora asocia la cultura con grupos sociales, de manera tal que las personas pueden pertenecer en forma simultánea a varios grupos y categorías que, a la vez, podrían interpretarse como agrupamientos culturales.

\subsection{Teoría del Género}

Mientras que en el registro el énfasis está puesto en el contexto de situación definido por las variables de campo, tenor y modo, la Teoría Funcional de Género se centra en factores sociales y culturales como los generadores de toda acción, incluyendo la acción lingüística (Taboada 2004: 12).

El estudio de los géneros discursivos y de las clases textuales en general se remonta a las primeras reflexiones sobre el tema de Mijail Bajtín ( 1981,1982) quien propone que los enunciados orales y escritos reflejan las esferas comunicativas donde se producen y que cada esfera comunicativa desarrolla clases estables de textos, a las que denomina géneros discursivos. Además, especifica qué aspectos son relevantes para dar cuenta de los géneros discursivos: su contenido, sus recursos léxicos y gramaticales, y su estructura 
(Bajtín 1982:248). Para poder elegir el abordaje teórico del presente trabajo, hemos revisado distintos modelos de análisis de los géneros discursivos y tipos textuales. Entre los autores consultados se encuentran Swales, 1990, 2001 y Bhatia $(1993,2004)$ que desarrollan su investigación desde la lingüística aplicada; Charaudeau, 2004 que lo hace desde una perspectiva semiótica discursiva; Heinemann 2000 y Heinemann y Viehweger 1991 que incorporan la descripción de rasgos internos al funcionamiento comunicativo de los textos desde la lingüística textual alemana o desde el análisis del discurso (van Dijk, 1997, 2002, 2008), entre otros.

Como ya mencionamos, nuestro interés está puesto en la estrecha relación entre contexto y texto. Halliday (1964) usó el término registro para referirse a "una variedad de acuerdo al uso en el sentido de que cada hablante tiene un espectro de opciones y escoge entre ellas en diferentes momentos." (Halliday et al. 1964: 77). Vale decir, que el registro se define a partir de los significados determinados por la situación (lo que está ocurriendo, quién está participando y qué rol está jugando el lenguaje) conjuntamente con las palabras y estructuras utilizadas en la realización de esos significados.

La Teoría del Género desarrollada en el marco de la LSF y siguiendo la propuesta de Halliday (1985), busca modelizar la estructura de constituyentes de los géneros o, según lo denomina Hasan (1984,1996: 53-54) establecer el potencial de estructura genérica que consiste en agregar al modelo sistémico original la especificación de una estructura semántica. El estudio de género dentro de la LSF se ha concentrado en las caracterizaciones estructurales a través de la identificación de etapas. Parte del análisis consiste en elaborar una fórmula que represente la secuencia típica de realización de la actividad descrita. La definición de género que maneja Hasan es cercana a la de registro de Halliday. En ambas propuestas, se considera conjuntamente la totalidad de las características contextuales como relevantes sin privilegiar el objetivo de la actividad social.

\footnotetext{
${ }^{8}$ Mi traducción: .... variety according touse in the sense that each speaker has a range of varieties and chooses between them at different times"
} 
A partir de los años 80, un grupo de investigadores pertenenciente a la vertiente Sistémico-Funcional desarrolló una teoría de las clases de textos que intenta distinguir entre el registro y el concepto de género discursivo de Bajtín. Los autores pertenecientes a lo que se denominó La Escuela de Género de Sydney, Australia (Martin 1985 , Martin 1992, Christie \& Martin 1997, Eggins \& Slade 1997) entienden al género de la siguiente manera:

Un género es una actividad que se desarrolla en etapas, con un objetivo y un propósito en la cual los hablantes se involucran como miembros de nuestra cultura (Martin 1984:155). ${ }^{9}$

De este modo, Martin (1984), principal exponente de la Escuela de Sydney, incorpora tres elementos principales al marco sistémico-funcional: En primer lugar, una estructura textual que se organiza en etapas con objetivos propios que gobiernan el género; en segundo lugar, una definición teleológica del género, vale decir que tiene un propósito en sí mismo; y, en tercer lugar, la incorporación de una dimensión de cultura que va más allá del contexto local o situacional. En la formulación de la Escuela de Sydney, el texto es la dimensión lingüística de una acción social con un objetivo determinado; se trata de una acción compleja, que implica la realización de ciertos pasos intermedios para obtener como resultado una estructura esquemática compuesta de partes o etapas que, además, persiguen objetivos específicos. Cada etapa de un género está orientada al éxito de los objetivos sociales que lo caracterizan y el género se organiza en un "orden global". Los textos resultantes son instancias particulares de un cierto tipo de interacción social o género (Véntola 1995:4). Según Véntola, el orden de los elementos puede variar y alguno de los elementos puede faltar, pero, a pesar de esto, estaremos en presencia de un mismo género siempre y cuando se lleve a cabo el mismo objetivo general (Véntola 1995:10). Las diferencias entre ejemplares de un mismo género pueden no deberse a la estructura genérica y la secuenciación sino a diferentes opciones de realización en los estratos inferiores del registro y la lengua. Otro aspecto que propone Martin es el diagrama de flujos que muestra una concepción dinámica del género (Martin 1995:553 en Moris y Navarro 2007) y pone el acento en el proceso de creación del texto, a diferencia de la propuesta

\footnotetext{
${ }^{9}$ Mi traducción: A genre is a staged, goal-oriented, purposeful activity in which speakers engage as members of our culture (Martin 1984:155).
} 
más estática y lineal de Hasan (cf.Hasan 1995:187 y ss.). En efecto, a diferencia de la autora, Martin y sus seguidores analizan el registro desde la perspectiva de la estratificación, como una estructura semiótica que realiza otra más general (Matthiessen 1993:225 y ss.). El gráfico a continuación muestra esta organización estratificada de la lengua y su contexto.

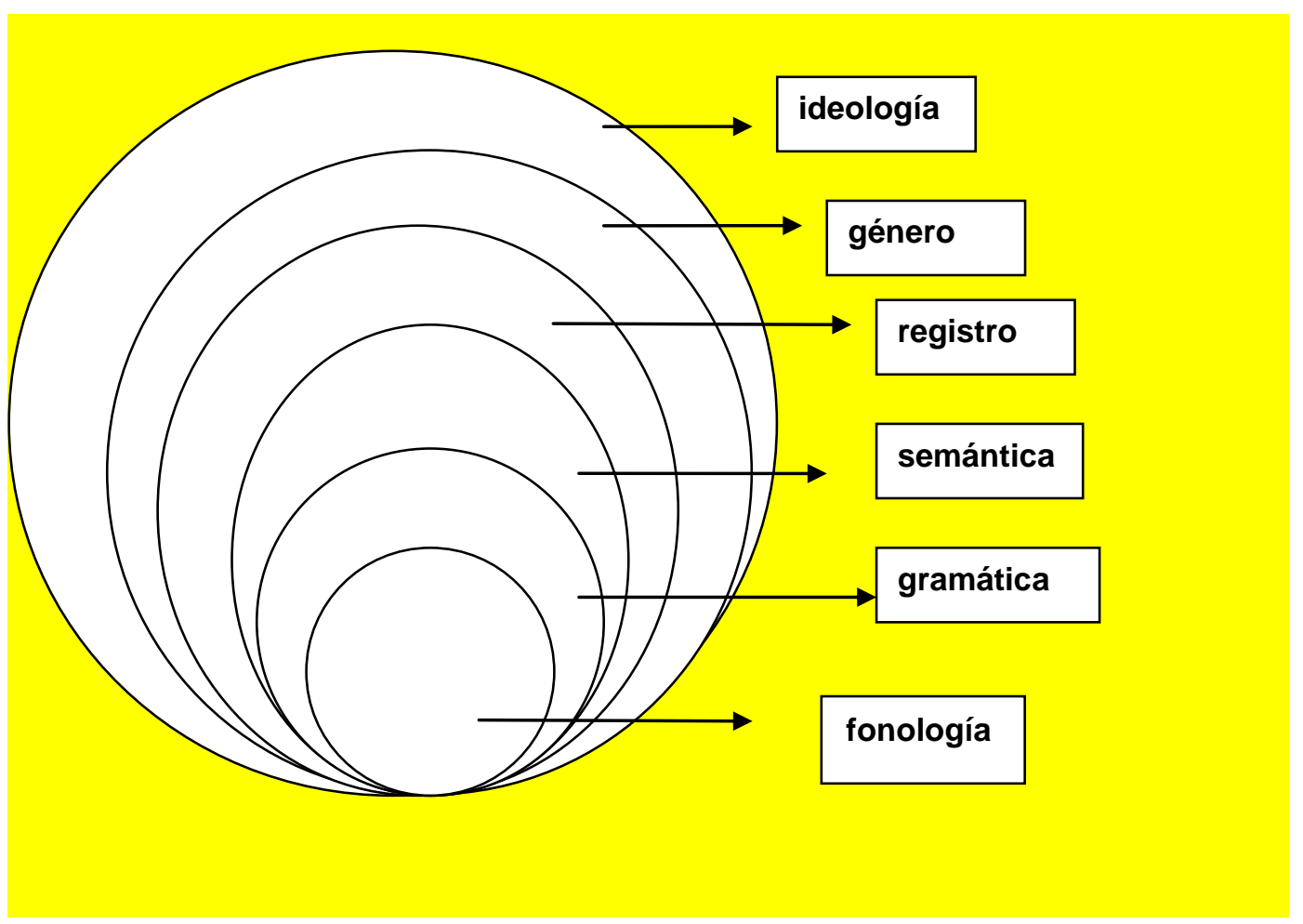

Gráfico 2.3 : Modelo de la lengua y su entorno semiótico (Martin 1992:496)

Como se puede observar, a la estratificación de contexto se le agrega el componente contextual general de la ideología que permite estudiar la distribución socio-histórica mediada por variables sociales de clase, edad, sexo, origen étnico de los géneros y registros. (Martin \& Rose 2003: 248). Este plano contextual superior permite incorporar al modelo una interpretación crítica de los planos comunicativos inferiores que, si bien se considera muy pertinente para el estudio de los textos que componen el corpus, en este trabajo solo se hace referencia tangencial del mismo.

La descripción que aquí se da de registro se asemeja a la descripción que Bajtín hace de géneros de la oralidad (speech genres) que se utilizan en diferentes esferas de la comunicación. (Taboada 2004). 
Al respecto, el lingüista ruso se expresa de la siguiente manera:

Aún en la conversación más libre, sin restricciones, emitimos nuestro discurso en formas genéricas definidas, a veces rígidas y trilladas, a veces flexibles, plásticas y creativas (la comunicación cotidiana también tiene a su disposición géneros creativos). Casi del mismo modo en que recibimos nuestra lengua madre, también recibimos los géneros conversacionales que manejamos con fluidez mucho antes de empezar a estudiar gramática. (...) si no existieran los géneros convesacionales y no tuviéramos dominio de ellos, si tuviéramos que inventarlos durante el proceso de habla y construir cada frase a voluntad por primera vez, la comunicación oral sería casi imposible. ${ }^{10}$ (Bajtín 1986: 78-79 en Taboada 2004)

De manera similar, Swales (1990) califica a la conversación y a la narración como pre-géneros.

Taboada (2004) señala que, si bien los géneros dan forma a nuestra comunicación cotidiana así como lo hacen las formas del lenguaje, existe una diferencia fundamental entre ambos: las formas del lenguaje son normativas, estables y obligatorias mientras que las formas genéricas son mucho más flexibles y pueden ser manipuladas para adaptarse a una situación o al propósito del hablante. Al respecto, Bajtín aclara que "no es lo mismo usar un género libremente y con creatividad que crear un género desde el principio; se debe tener pleno dominio de los géneros para poder manipularlos libremente." (Bajtín 1986:80 en Taboada 2004: 9). La autora hace referencia al concepto de género como una receta para producir un texto pero aclara que no es simplemente un esquema o marco para la acción. El género implica formas, características de hacer textos así como formatos característicos de relaciones interpersonales y significados ${ }^{11}$ (Threadgold 1989:96). Asimismo, Taboada sostiene que el género también permite un foco dual tanto sobre la visión

\footnotetext{
${ }^{10} \mathrm{Mi}$ traducción del original en inglés: Even in the most free, the most unconstrained conversation, we cast our speech in definite generic forms, sometimes rigid and trite ones, sometimes are flexible, plastic, and creative ones (everyday communication also has creative genres at its disposal). We are given these speech genres in almost the same way that we are given our native language, which we master fluently long before we begin to study grammar. (..) if speech genres did not exist and we had not mastered them, if we had to originate them during the speech process and construct each utterance at will for the first time, speech commuication would be almost impossible. (Bajtín 1986: 78-79 en Taboada 2004)

${ }^{11}$ Mi traducción del original en inglés: Genres are both products and processes-systems and performances. Each time a text is produced so as to realize and construct a situation - type it becomes the model for another text anda another situation-type. As a model, it functions like a static, finished product or a system according to which new texts can be constructed. Once the constructing begins it becomes again a dynamic process, a performance which will enevitably change the model with which it begins. This means that we have to teach the interpersonal and textual characteristic of genres, the probabilistic, dynamic aspects of their performance as well as their schematic structures. (Threadglold (1989: 100) en Taboada 2004:13)
} 
sinóptica del texto como producto como sobre la perspectiva dinámica del texto como proceso. Threadglold (1989: 100) lo define de la siguiente manera:

Los géneros son tanto "productos" como "procesos"- "sistemas" y "actuaciones" (performances). Cada vez que se produce un texto para realizar y construir un tipo de situación éste se transforma en modelo para otro texto y otro tipo de situación. Como modelo funciona como un producto estático y terminado o un sistema de acuerdo con el cual pueden construirse nuevos textos. Una vez que comienza la construcción, ésta se transforma nuevamente en un proceso dinámico, una actuación que inevitablemente va a cambiar el modelo con el que comienza. Esto significa que tenemos que hacer hincapié en las características interpersonales y textuales de los géneros, los aspectos probabilísticos y dinámicos de su actuación así como sus estructuras esquemáticas. (Threadglold (1989: 100) en Taboada 2004:13)

La definición operacional de género que propone Taboada, coincidente con la propuesta de Sydney, tiene que ver con aspectos de la determinación estructural de los textos. A un texto dado se lo percibe como perteneciente a un género por sus características estructurales, vale decir, las etapas en las que se estructura. Estas etapas están determinadas por la función del texto en una situación dada. El término amplio "función" abarca dos aspectos diferentes: el propósito comunicativo del texto y su función social.

Para resumir, podemos decir que La Teoría del Género (la vertiente de la Escuela de Sydney en particular) sugiere que los textos que cumplen diversas tareas en la cultura se desarrollan en forma diferente, a través de etapas o pasos (Eggins y Martin 1997:236). Martin (1986무) explica que, contrariamente a la propuesta de Halliday (1978) y Halliday y Hasan (1985), el modelo que él propone incluye la cuarta variable denominada género que domina a las variables tradicionales de campo, tenor y modo. Así, el género determina las etapas de un texto de acuerdo a propósitos tanto comunicativos como sociales y su influencia en el lenguaje utilizado está mediada a través del registro. (Taboada 2004: 25,26). Desde ese punto de vista, "registro y género son dos planos de realización en una visión semiótica social del texto, visión que sostiene que los textos no son codificaciones neutras de una realidad natural, sino construcciones semióticas de significados construidos socialmente" (Eggins y White 2003). Visto de este modo, el texto es tanto una realización de tipos de contexto como la escenificación de lo que interesa a los miembros de 
una cultura en situaciones determinadas. En el estudio de los textos veremos la aplicación del análisis semántico en el nivel léxico, gramatical y discursivo para descubrir las elecciones lingüísticas que escenifican esta relación semiótica entre lenguaje y contexto. También veremos que el análisis funcional del género no se limita a la descripción de los patrones lingüísticos detectados en los textos sino que el mismo favorece un análisis crítico, que busca revelar y explicar la forma en que los textos sirven a propósitos diversos en la construcción discursiva de la vida social (Martin y Eggins 2003:199). Asimismo, nos interesa enfatizar el hecho de que bajo la elección de géneros y la construcción de un texto coherente en términos de registro, existen posiciones e intereses a los que el discurso debe servir. Si bien el registro y el género constituyen dos perspectivas importantes para el texto en contexto, también se requiere una tercera dimensión 'crítica' que enfoca consideraciones ideológicas (Oteíza, 2006)

\subsection{Teoría de la Valoración ${ }^{12}$}

El estudio de la evaluación en el lenguaje se ha manifestado a través de de una gran variedad de perspectivas tanto en el discurso oral (Grimes, 1975; Labov,1972; Sinclair y Coulthard, 1975) como en el escrito ( Hoey,1983;Tadros, 1994; Winter 1994, entre otros).

La Teoría de la Valoración (Appraisal Theory) (Martin 1995ª,1995b,1997,2000; Martin y Rose, 2003; Martin y White 2005; White, 1998,2000,2002,2003,2004, entre otros) corresponde a una reorientación del trabajo de Halliday (1994) y su investigación sobre la modalidad desarrollada en el marco de la LSF (Halliday, 1985,1994; Eggins, 1994; Martin 1992, Matthiessen, 1995 y Thompson 1996 entre otros). Su objetivo ha sido presentar una reorganización abarcativa y sistemática de los recursos que pueden usarse para valorar la experiencia social. Oteíza 2009 hace hincapié acerca de lo que White 2003 sostiene en esta teoría. El autor señala que la misma busca dar respuesta a un creciente

\footnotetext{
${ }^{12}$ La traducción al español de los términos originales en inglés correspondientes a la Teoría de la Valoración fueron tomados de la traducción ralizada por Elsa Ghio (disponibles en http://www.grammtics.com/appraisal/).
} 
interés en la investigación reciente por explorar cómo los lenguajes construyen roles sociales y el potencial del lenguaje para operar retóricamente, para influir sobre creencias, actitudes, expectativas y modos de relacionarse. Dentro de este marco teórico, entonces, el análisis apunta a la descripción y explicación de los sistemas de opciones semánticas que ofrece el lenguaje para evaluar, adoptar posiciones, construir personas textuales o identidades discursivas, asumir roles, negociar relaciones, y transformar en "naturales" las posturas intersubjetivas que son, en definitiva, ideológicas. La Teoría de la Valoración se ocupa en particular de la expresión lingüística de la actitud, así como del conjunto de recursos que, en forma explícita, posicionan de manera interpersonal las "propuestas" y proposiciones textuales (Halliday, 1994 en Kaplan, 2007). Oteíza 2009 sostiene que desde la perspectiva dialógica de Bajtín, incorporada a la Teoría de la Valoración, las estrategias evaluativas pueden entenderse como una monoglosia o una heteroglosia $u$ orientaciones más o menos dialógicas que los autores adoptan para construir cierta solidaridad ideológica con sus lectores en relación a lo expuesto en el discurso. Para Bajtín, la solidaridad ideológica guarda relación con los estilos considerados como 'objetivos' o 'neutrales' que presuponen una especie de identificación entre el destinatario y el hablante generando una unidad de sus puntos de vista. Se considera la 'solidaridad ideológica' como el posicionamiento de los emisores en el discurso que da por sentado un mismo alineamiento ideológico por parte de su audiencia; es decir, supone que los receptores comparten las mismas creencias sobre el tema tratado. Las ideologías, por su parte, son entendidas como un sistema de creencias fundamentales 0 axiomáticas y relativamente estables, socialmente compartidas por los miembros de una colectividad de actores sociales (van Dijk, 1998, 2005).

\section{Los dominios semánticos de la Valoración}

Encuadrado en el concepto socio-lingüístico de registro (Halliday, 1978) los investigadores que trabajan con la Teoría de la Valoración ponen especial énfasis en la variable contextual de "tenor". Esta teoría divide los recursos evaluativos en tres grandes dominios semánticos: el Compromiso, la Actitud, y 
la Gradación. ${ }^{13}$ El Compromiso se refiere a los recursos lingüísticos que pueden utilizarse para posicionar la voz de los hablantes o productores de textos, la Actitud incluye los significados por los cuales los hablantes o productores de textos atribuyen un valor o una evaluación intersubjetiva a participantes, procesos y circunstancias y la Gradación está relacionada con la manera en que los emisores intensifican o disminuyen la fuerza de sus enunciados y agudizan o desdibujan el foco de sus categorizaciones semánticas ( Martin y White 2005).

El gráfico que reproducimos a continuación muestra los tres dominios semánticos de la Valoración y los subsistemas en los que se organizan.

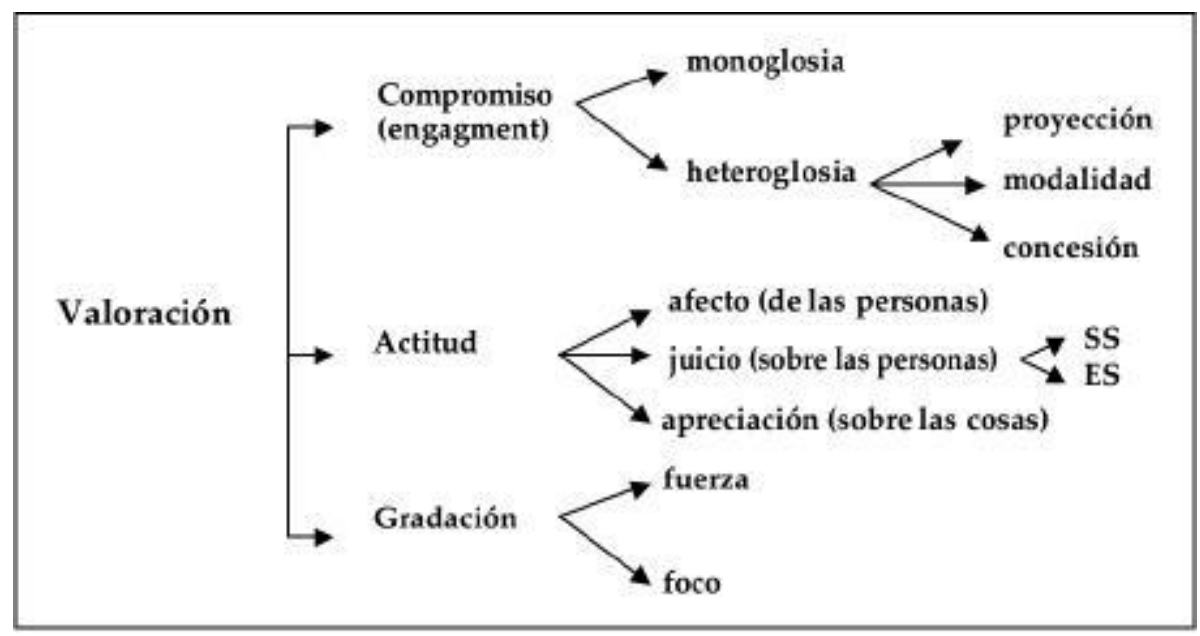

Gráfico 2. 4: Esquema general de la Teoría de la Valoración (Appraisal) Martin y Rose (2003:

54)

\subsubsection{El dominio semántico del Compromiso (Engagement)}

El subsistema de Compromiso nos permite un estudio más detallado y flexible en cuanto a la recuperación de los significados interpersonales inscritos 0 evocados en el discurso y la identificación de los recursos léxicos y gramaticales que los autores utilizan para subjetivizar sus voces, explícita (inscripción) o implícitamente (evocación), y establecer una solidaridad

\footnotetext{
${ }^{13}$ Si bien, de acuerdo a la tradición de la LSF, los nombres de los sistemas de la Valoración deberían escribirse en bastardilla, en el presente trabajo solo se escribe en mayúscula la letra inicial.
} 
ideológica con sus posibles lectores así como influir de forma indirecta y hacer que las creencias y supuestos parezcan naturales. (Oteíza, 2009: 222).

Como ya anticipáramos, las principales opciones en el dominio semántico del Compromiso se ubican en dos dimensiones contrapuestas: la monoglosia y la heteroglosia (White, 2003). White sostiene que para describir y explicar la función que cumplen los recursos de la Valoración dentro de la comunicación, es necesario considerarlos como fundamentalmente dialógicos o interactivos, es decir, que por medio de ciertos elementos lingüísticos -que han sido estudiados como modalizaciones, atenuaciones, intensificaciones, atribuciones, etc.- la voz del texto actúa para reconocer, comprometerse o alinearse con respecto a las posiciones que se presentan como alternativas a las que presenta el texto. Asimismo, White (2003) entiende que el escritor/hablante asume un compromiso con respecto a las proposiciones que emite, es decir que a la vez que toma un posicionamiento, también construye a su audiencia como en consenso o disenso con esas proposiciones.

La monoglosia puede definirse, de acuerdo con White (2000) y Martin y Rose (2003), como la orientación en el discurso en la que no se reconocen posiciones alternativas en relación a evaluaciones determinadas. La manifestación más acabada de la monoglosia es la afirmación categórica (bare assertion) ya que con este recurso no se da lugar a la diversidad de voces que se ponen en juego en todo acto de comunicación. Por esta razón, los enunciados monoglósicos no son considerados formas comunicativas neutras y no modalizadas por defecto, sino que la Teoría de la Valoración los concibe como una manera de adoptar posturas socio-semióticas de gran fuerza retórica e interpersonal, que entran en relaciones de tensión con posibles enunciados alternativos e incluso contradictorios (White 2003 en Kaplan 2007).

Por el contrario, con las emisiones heteroglósicas se reconoce la existencia de otras voces pero no siempre se dialoga con ellas. White (2003) subdivide las emisiones heteroglósicas en dos grandes grupos: las que abren el espacio al sostener posiciones y voces dialógicamente alternativas (expansión dialógica), y las que lo cierran al desafiar o restringir el alcance de las mismas 
(contracción dialógica). El siguiente gráfico muestra el sistema del Compromiso heteroglósico, que comprende los recursos de expansión y de contracción del espacio dialógico, con sus sub-categorías:

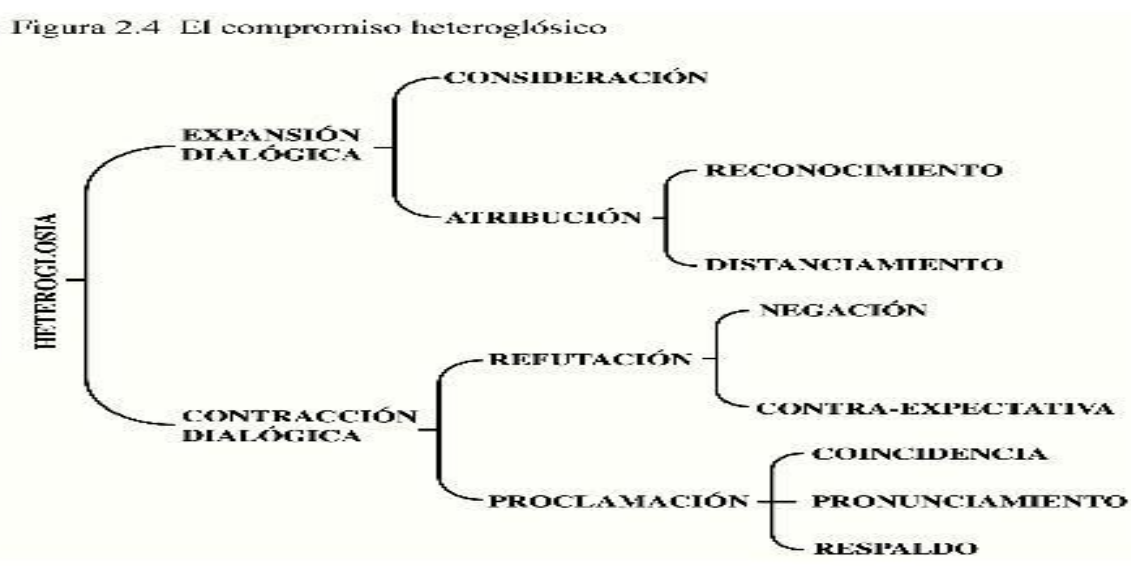

Gráfico 2.5: La heteroglosia en el discurso dentro del sistema del Compromiso.( White 2003: 272)

White (2003) y Martin y White (2005) dividen a los recursos de expansión dialógica en las siguientes categorías: (a) La "consideracion", con la que la voz textual del hablante o autor considera o invoca a otros puntos de vista diferentes del suyo, e indica que aunque esté muy comprometida con su evaluación, ésta no es sino una más entre varias otras posibles en ese contexto comunicativo. Martin y White (2005) incluyen en esta categoría a las modalidades epistémica y deóntica. (b) La "atribución" pertenece a los recursos de extravocalización. Martin y White (2005) incluyen dentro de ella a todas las expresiones que desvinculan la proposición de la voz que produce el texto, atribuyéndosela a una fuente externa. Los investigadores de la Teoría de 
la Valoración reconocen la afiliación con autores que han estudiado la atribución de la información en lengua inglesa, por ejemplo, Sinclair 1986, Tadros 1993, 1994, Caldas-Coulthard 1994, pero a la vez proponen un abordaje original de esta teoría en la cual lo prioritario es el estudio de la función dialógica de la atribución, más que la identificación de la fuente original de la proposición atribuida. Desde el punto de vista dialógico, la Teoría de la Valoración distingue entre el "reconocimiento" del discurso atribuido, y el "distanciamiento" respecto de este. El primero corresponde a construcciones enmarcadas en verbos de habla aparentemente no valorativos, como decir, preguntar, que simplemente admiten o reportan las palabras de voces externas. Con el segundo, la voz textual se distancia de la proposición referida, mediante verbos de reporte que expresan esa toma de distancia, como alegar, aducir. Dado el importante rol que cumple la atribución de la palabra en los textos analizados en el presente trabajo, pondremos especial énfasis en esta categoría en particular.

Por otro lado, con los recursos de contracción dialógica, los hablantes y autores se anticipan a cualquier duda o resistencia por parte de sus interlocutores o lectores. Según White (2003), y Martin y White (2005), estos recursos incluyen la "refutación" y la "proclamación". La "refutación" implica el rechazo directo o la contradicción de la posición dialógica opuesta. Esta categoría se subdivide, a su vez, en la "negación" y la "contra-expectativa". Luego de la monoglosia, la negación es el recurso que más contrae el espacio dialógico porque el emisor, como voz textual, reconoce e introduce en el discurso una posición positiva alternativa, para rechazarla al mismo tiempo. Con este recurso de confrontación y rechazo, el emisor contrae el espacio dialógico entre su voz y las otras posibles alternativas. Con la contraexpectativa, o concesión, el emisor también toma en consideración las posibles expectativas de los interlocutores, y las ajusta - y contradice - a medida que el texto se despliega. Hay aquí también una contracción del espacio dialógico. Este manejo de las expectativas se realiza por medio de conjunciones adversativas, adverbios y locuciones adverbiales de concesión, de contraste, de tiempo, de causa, así como de marcadores de lo inesperado. Muchas 
veces, la concesión puede acompañar a la negación, pues es considerada una forma de refutación.

La "proclamación", que se utiliza cuando la voz textual pretende señalar que está altamente comprometida con el punto de vista que emite, hecho que incrementa en el receptor el riesgo, desde el punto de vista interpersonal, de oponerse a esa postura. Esta categoría se subdivide en los recursos de "coincidencia", "pronunciamiento" y "respaldo". Con los valores de "coincidencia", los emisores representan sus proposiciones o propuestas (Halliday 2004 en Kaplan 2007) como "dadas" o irrefutables, ya que coincidirían con los conocimientos o creencias de la mayoría. Estos recursos tienen asimismo la función retórica de crear un acercamiento con los receptores (White 2003:272). Con el "pronunciamiento", los emisores se introducen directamente en el texto como la fuente responsable del enunciado. Estos recursos pueden tomar la forma de una intervención explícita del autor en el texto. Tanto la coincidencia como el pronunciamiento son recursos de intravocalización. El "respaldo", en cambio, es un recurso de extra-vocalización que representa el apoyo de los emisores a la veracidad o la validez del enunciado atribuido. Dentro de esta categoría, nuestro análisis se centrará más específicamente en los recursos de intravocalización de "coincidencia" y "pronunciamiento".

\subsubsection{El dominio semántico de la Actitud}

El otro dominio semántico relevante para nuestro estudio es el de la Actitud. Se clasifican como actitudinales todos los enunciados que transmiten una evaluación positiva o negativa, o que pueden ser interpretados como una invitación a los interlocutores a emitir sus propias evaluaciones positivas o negativas. Esta categoría se divide en los subsistemas de Afecto, Juicio y Apreciación (Martin y White 2005).

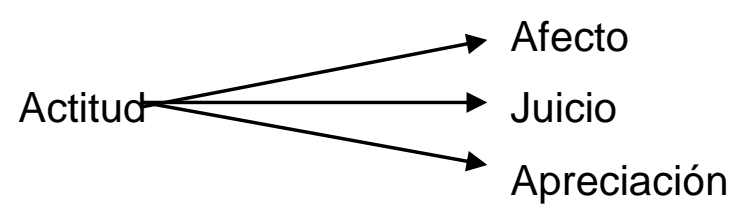

Gráfico 2.6: El subsistema de la Actitud. Martin y White (2005). 
White (2003) señala que la categoría Afecto puede considerarse como el sistema actitudinal básico, mientras que el Juicio y la Apreciación constituyen formas derivadas que surgen de la institucionalización de las emociones. En otras palabras, White sostiene que se podría considerar a la Apreciación como el sistema mediante el cual los sentimientos humanos hacia productos, procesos y entidades se institucionalizan como un conjunto de evaluaciones positivas o negativas. Con estos valores, se evalúan objetos, y constructos abstractos. Asimismo, el autor asevera que los seres humanos tomados como entidades, más que como participantes que tienen comportamiento, pueden ser evaluados mediante recursos de Apreciación. En el presente trabajo nos hemos detenido en el subsistema actitudinal del Juicio (Martin y White 2005) ya que esos significados se manifiestan con alta frecuencia en los textos analizados e inciden notablemente en su configuración. Este subsistema comprende significados que sirven para evaluar positiva o negativamente el comportamiento humano, en relación con un conjunto de normas institucionalizadas. Las normas sociales que se ponen en juego en estas evaluaciones de Juicio adoptan la forma de reglas, o de expectativas sociales y sistemas de valor condicionados por una cultura dada.

El Juicio puede clasificarse, según Martin y White (2005), en dos grandes categorías:(a) Juicios de estima social, subdivididos, a su vez, en aquellos relativos a la normalidad, la capacidad o la tenacidad demostrada en la conducta. Con estos valores de Juicio, se evalúa a las personas en cuanto corrientes, competentes, y decididas. Las personas evaluadas con juicios de estima social podrían ver aumentado o disminuido su prestigio dentro de su entorno social, sin ninguna otra consecuencia. (b) Juicios de sanción social, relacionados con la veracidad y la integridad. Se trata de la evaluación de la sinceridad y la ética en la conducta de los individuos. Las evaluaciones de sanción social podrían llegar a tener efectos mucho más severos, ya que lo que está implícito es el respeto o, por el contrario, la violación de reglas morales, legales o religiosas (Martin 2000). Como ya señalamos en otras oportunidades, para la Teoría de la Valoración (Martin y White 2005), el sistema de Juicio está constreñido por la situación cultural e ideológica particular en la que opera. La forma en que las personas evalúan en su discurso la moralidad, la capacidad, o 
cualquier otro rasgo de la conducta humana, está siempre determinada por la cultura que dichas personas están insertas, así como por sus experiencias y creencias individuales. Por eso, cabe siempre la posibilidad de que una misma conducta sea valorada de diferente manera según sea la posición ideológica de quien emite el juicio. Del mismo modo, una palabra específica no siempre tendrá el mismo valor como juicio sino que este valor estará determinado por su posición en el texto así como por los otros juicios que se hayan emitido previamente. Finalmente, los Valores de Juicio pueden realizarse mediante adverbios, atributos y epítetos, nombres con valores positivos o negativos y, a su vez, pueden ubicarse en una escala de mayor a menor grado. Cuando el juicio de valor se expresa mediante una determinada elección léxica, se habla de expresiones de juicio 'inscritas', porque la evaluación se 'inscribe' explícitamente en el texto. Sin embargo, la evaluación podría permanecer implícita o ser evocada de manera más indirecta mediante los llamados indicadores $\mathbf{o}$ indicios de Juicio. Con estos últimos, la descripción aparentemente fáctica, no evaluativa, de un hecho o una situación, puede desencadenar una evaluación actitudinal enjuiciatoria. Al respecto, Martin y White (2005:62) afirman que "la selección de significados ideacionales es suficiente para invocar evaluación, incluso en ausencia de léxico actitudinal que nos dice de manera directa como sentirnos". ${ }^{14}$ Los indicadores de Juicio pueden definirse, por lo tanto, como las interacciones que se producen entre significados ideacionales e interpersonales. Para Martin y White (2005), desconocer esta interacción implicaría admitir que los emisores seleccionan los significados ideacionales que desean transmitir sin tomar para nada en cuenta las actitudes que podrían generar en sus receptores. Y admitir esto, según los autores mencionados, es una posición insostenible para un analista del discurso.

\subsubsection{El dominio semántico de la Gradación}

Por último, según Martin y Rose (2008) el dominio semántico de la Gradación es un espacio relacionado con la manera en que los hablantes y productores

\footnotetext{
${ }^{14}$ Mi traduccion del inglés en el original: "(...) the selection of ideational meanings is enough to invoke evaluation, even in the absence of attitudinal lexis that tells us directly how to feel" (Martin y White 2005:62).
} 
de textos intensifican o disminuyen la fuerza de sus enunciados y gradúan el foco de sus categorizaciones semánticas. Los valores de fuerza se ubican en una escala de intensidad de baja a alta, y se identifican tanto con el aspecto léxico. El foco se define como el dominio de aplicación de las escalas de intensidad a categorías no susceptibles de gradación. Con estos recursos, se hace graduable algo que inherentemente no lo es (por ejemplo medio deshonesto, o un poco enfermo). Estos valores se utilizan para evaluar si las entidades poseen o bien un significado experiencial con límites claramente definidos o, en el otro extremo, imprecisos o desdibujados. Según White (2004 en Kaplan 2007:83), estos valores son equivalentes a lo que Lakoff (1972) denominó "evasivas".

\section{Reflexión final}

El propósito general de este trabajo, como se expresa en la Introducción, es el de estudiar y establecer la estructura que organiza el género de las homilías en estudio así como identificar y caracterizar aspectos evaluativos salientes. Si se reconsidera este hecho a la luz de la descripción del modelo de lengua sistémico-funcional que se ha presentado en esta sección, probablemente se advierta que este trabajo pretende poner en relación los distintos niveles mencionados a saber, la lengua, más específicamente el nivel léxico-gramatical $y$, dentro de éste el sistema de valoración con el contexto de situación y cultura, y el modo en que éste se manifiesta en el género analizado. Acordamos con Taboada 2004 que La Teoría Funcional del Género ha sido de gran utilidad como herramienta de investigación ya que concibe aspectos sociales y culturales como los factores que generan toda acción, incluyendo la acción lingüística, a través del concepto de género. Asimismo, al elegir la Teoría de la Valoración como parte del marco teórico del presente trabajo intentamos adentrarnos en el carácter interpersonal y dialógico de la comunicación. Sin duda, este enfoque resulta ser también una herramienta sumamente útil al momento de integrar aspectos funcionales en un análisis semántico-discursivo. Ambas teorías proponen un desarrollo muy completo que ofrece todos los elementos para dar cuenta de las evaluaciones, por un lado, y establecer las características de un género determinado, por el otro, construyendo así un 
punto de partida sumamente valioso. Otro hecho de relevancia en el presente abordaje tanto en la Teoría del Género como de la Valoración es la importancia que se atribuye no solo a aspectos contextuales y culturales sino también a la apertura ante la posibilidad de múltiples lecturas de los significados actitudinales teniendo en cuenta las creencias e ideología de quien produce un texto así como el entorno en el que ese texto se emite.

\section{4 Estado de la cuestión}

Entendemos que la homilía ha sido un género muy estudiado desde distintas vertientes teórico-analíticas en nuestro medio. De los trabajos que tenemos noticia, se destacan algunos en los que se aborda, además del análisis de las propiedades lingüístico-textuales que caracterizan a la homilía como género discursivo, la relación existente entre el discurso de la Iglesia católica y otros tipos de discurso. Los trabajos de Arnoux (2004), Arnoux y Blanco $(2003,2004)$ y Bonnin (2009) analizan "corpora" compuestos por homilías pronunciadas por actores sociales que ocupan lugares de relevancia dentro de la jerarquía de la estructura de la Iglesia Católica Argentina y que, dado el contexto en que se emiten, construyen sus textos con características del discurso religioso y el discurso político. Las autoras abordan los textos desde la perspectiva de la argumentación en la lengua y la polifonía (Ducrot 1990). Por su parte, Bonnin (2009) hace un análisis de un debate político entre un obispo católico y el presidente de la Nación, Raúl Alfonsín ocurrido dentro de una celebración religiosa en conmemoración del desembarco argentino en las islas Malvinas. El autor intenta explicar un caso en el que una homilía que habitualmente es de carácter monológico, se construye como un intercambio polémico más cercano al debate político. Este desplazamiento de la homilía hacia el discurso político en el que el locutor, violando una norma constitutiva del género homilético, construye una representación enunciativa del presidente como contradestinatario, habilita a que el mismo apele a ese carácter teóricamente dialógico del género para responder en el mismo ámbito. Asimismo, Bonnin (2010), hace un estudio sincrónico y diacrónico de tres géneros discursivos producidos por la Conferencia Episcopal Argentina (cartas políticas, 
declaraciones y comunicados) durante el proceso de transición a la democracia. Los resultados del análisis muestran cómo los géneros, analizados desde la vertiente de la lingüística textual alemana, se reorganizan por motivos tácticos adaptando un mismo sistema de creencias a nuevas circunstancias comunicativas dadas por la transición a la democracia. La homilía ha sido también estudiada desde el punto de vista de sus procedimientos argumentativos (Acebal 2002, 2006) y como género dentro del marco de la LSF (Acebal 2007 y 2010). En estos trabajos se han estudiado las relaciones entre el texto bíblico y la paráfrasis del mismo así como ciertos elementos de la contextualización del texto bíblico fuente. Si bien coincidente en parte con nuestra investigación, el autor hace un análisis de homilías católicas en general emitidas en la ciudad de Santa Fe, Argentina y no se detiene a desarrollar la estructura esquemática del género limitándose al análisis de la etapa que el autor denomina de actualización o aplicación. Por lo tanto, consideramos que el análisis detallado del género homilético de misas de Tedeum de 25 de mayo con la presencia de autoridades nacionales, llevado a cabo desde la misma perspectiva y la elaboración de nociones de acuerdo a las características particulares de los textos se justifica particularmente en una tesis de orientación cualitativa como la presente.

Se indagó acerca de la existencia de estudios de textos religiosos en general y homilías en particular en idioma inglés ya que se podrían haber leído sin dificultad pero solo se encontraron análisis de sermones y textos sagrados desde otros abordajes teóricos, como es el caso de un artículo de Mark Garner (2007) en el que se hace un análisis de sermones de un teólogo escocés, Robert Rollock (1555-1599). El autor parte de la premisa de que el sermón toma la forma del objetivo comunicativo del predicador y se propone explicar la relación entre el sermón como texto y su situación social histórica y teológica. (http://www.equinoxjournals.com/RRR/article/viewArticle/4416). Asimismo hemos encontrado en nuestra búsqueda en internet, otro estudio hecho en Cracovia por Ruta Nagucka (2002) de la Universidad Jagellonian quien aborda ciertos ítemes léxicos de homilías en Inglés antiguo e intenta una interpretación de los mismos tomando en cuenta el contexto en el que esos términos son utilizados así como la posición del propio autor. 
(http://ifa.amu.edu.pl/sap/files/38/24nagucka.pdf). Aparte de los trabajos mencionados, no tenemos noticia de estudios realizados desde la LSF en ningún discurso religioso. 


\section{METODOLOGÍA DE ANÁLISIS}

\subsection{Corpus}

Se entiende a la homilía como el paso intermedio entre la Palabra de Dios-la cual es transmitida por medio de una lectura bíblica como un pasaje ejemplary la realidad en la que se emite. La tarea del emisor consiste en recontexualizar el mensaje bíblico mediante la prédica y ofrecer a la audiencia una visión renovada y actualizada de los mismos valores expresados en las sagradas escrituras. Puesto que ha habido una notoria evolución en los estudios exegéticos, queda mucho librado a la interpretación que se pueda hacer de la lectura tomada de la Biblia al momento de su aplicación a la vida actual de la feligresía.

Hace años, el ministerio de la homilía se solía reservar en todas las misas a un canónigo específicamente preparado para la predicación a quien se lo denominaba canónigo magistral. En la actualidad, todo sacerdote ordenado tiene acceso a la homilía que dirige a sus fieles, sin embargo la mayoría de las homilías que componen el "corpus" al ser parte de la celebración oficial de la Revolución de Mayo, son pronunciadas o bien por el Arzobispo de Buenos Aires, o por obispos a cargo de las diócesis donde el o la presidente elige celebrar la misa de Tedeum.

En este trabajo, de acuerdo a lo expuesto en la introducción, se presenta un análisis del discurso de las Homilías de Tedeum de 25 de mayo en Argentina ante las autoridades nacionales. Los textos que componen el corpus fueron tomados de distintos medios escritos ya que, si bien se los da a conocer en forma oral, son textos redactados con anterioridad para ser leídos y luego publicados.

Los primeros textos, correspondientes a los años 1976, 1979 y 1980, fueron tomados del Boletín Eclesiástico disponible en la Biblioteca del Arzobispado de la ciudad de Buenos Aires. Las homilías correspondientes a los años 1987, 
1993, y 1996 se tomaron de los diarios La Nación y La Prensa consultados en su mayoría en la biblioteca de la Legislatura de la provincia de Buenos Aires en la ciudad de La Plata. Para poder transcribir los textos fue necesario tomar fotografías de los diarios que en los años mencionados reprodujeron las homilías en su totalidad. Los textos producidos a partir del año 1999 fueron tomados de Internet ya que a partir de ese año empiezan a publicarse en forma digital en la página de la Agencia Informativa Católica Argentina (AICA). Si bien mi intención era contar con todas las homilías no me fue posible encontrarlas ya que en los diarios solo hacían una reseña de la celebración y citaban algunos párrafos aislados. Por su parte, en el Boletín eclesiástico tampoco se reproducían las homilías de todos los años, hecho que me obligó a tomar solo las publicadas. La recolección de todos los textos que componen el corpus para el presente estudio, fue hecha entre los años 2007 y 2008.

En primer lugar, nos hemos concentrado en las homilías de las misas de Tedeum del 25 de mayo del año 1976, dos meses después del golpe de estado, las correspondientes a los años 1979 y 1980 momento en que el cuestionado accionar del gobierno de facto respecto de la desaparición de personas ya estaba difundido, especialmente en el exterior. Por tal motivo, la OEA envía en septiembre del año 1979 una delegación de la Comisión Interamericana por los Derechos Humanos que elabora un informe denunciando las aberrantes violaciones a los derechos humanos. En este momento, se instala el lema "los argentinos somos derechos y humanos" que el gobierno de facto ofrece como respuesta al informe de la Comisión. La Iglesia no ofreció apoyo alguno a la Comisión ya que la mayoría de los obispos y demás miembros de su cúpula jerárquica cooperaba en forma directa con la dictadura militar. ${ }^{15}$ Finalmente, para poder mostrar de qué manera el discurso de las homilías se va modificando según el contexto en el que se producen, tomamos homilías emitidas una vez recuperada la democracia y su posterior consolidación, durante la presidencia de Raúl Alfonsín (1987), Carlos Menem (1993,1996,1999), Fernando de la Rua $(2000,2001)$, Eduardo Duhalde (2002) Néstor Kirchner (2003-2007) y Cristina Fernández de Kirchner (2008-2010). 
Los textos completos se presentan en orden cronológico en el ANEXO. Como ya señalamos, las homilías fueron seleccionadas teniendo en cuenta tanto el contexto histórico en el que se pronunciaron como la disponibilidad de las mismas en su totalidad en medios escritos como diarios o boletines institucionales. En ningún caso hay certeza acerca de la autoría de los mismos, aunque en el análisis se le confiera al locutor el carácter de responsable, si no de su redacción al menos de su emisión.

El género en el que nos centramos es uno de los que la Iglesia argentina utiliza para tomar una postura crítica cuando el partido político opositor deja de cumplir dicha función, ya sea por falta de representatividad o por la misma acción del gobierno de turno (Di Stefano y Zanatta 2000). Podríamos decir que la Iglesia, más allá del lugar que ocupan los partidos políticos o agrupaciones de una determinada ideología, está siempre presente para hacer oír su voz muchas veces opositora.

En el siguiente cuadro se detalla el año, el celebrante, que , como ya dijimos, no necesariamente es el autor del texto, el presidente de la república presente en la celebración, el lugar donde se celebró la misa de Tedeum y la fuente de donde se tomó el texto. 


\begin{tabular}{|c|c|c|c|c|}
\hline \multicolumn{5}{|c|}{ HOMILÍAS DE TEDEUM DE 25 DE MAYO } \\
\hline AÑO & CELEBRANTE & AUTORIDAD & LUGAR & FUENTE \\
\hline 1976 & Mons. Horacio Bozzoli & $\begin{array}{l}\text { Junta Militar } \\
\text { Presidente J.R. } \\
\text { Videla }\end{array}$ & $\begin{array}{l}\text { Buenos } \\
\text { Aires }\end{array}$ & $\begin{array}{c}\text { Boletín } \\
\text { Eclesiástico } \\
\text { del Arzobisp } \\
\text { de Bs As. }\end{array}$ \\
\hline 1979 & $\begin{array}{c}\text { Cardenal Juan Carlos } \\
\text { Aramburu } \\
\text { Arzobispo de BA y } \\
\text { presidente de la } \\
\text { conferencia episcopal. }\end{array}$ & $\begin{array}{l}\text { Junta militar. } \\
\text { Presidente: J R } \\
\text { Videla }\end{array}$ & $\begin{array}{l}\text { Buenos } \\
\text { Aires }\end{array}$ & $\begin{array}{l}\text { Diario La } \\
\text { Nación }\end{array}$ \\
\hline 1980 & $\begin{array}{l}\text { Mons. Daniel J. Keegan } \\
\text { Rector de la catedral } \\
\text { metropolitana }\end{array}$ & $\begin{array}{l}\text { Junta Militar } \\
\text { Presidente: J.R. } \\
\text { Videla }\end{array}$ & $\begin{array}{l}\text { Buenos } \\
\text { Aires }\end{array}$ & $\begin{array}{l}\text { Diario La } \\
\text { Nación }\end{array}$ \\
\hline 1987 & $\begin{array}{c}\text { Sacerdote Rómulo } \\
\text { Puiggari }\end{array}$ & Alfonsín & $\begin{array}{l}\text { Buenos } \\
\text { Aires }\end{array}$ & $\begin{array}{c}\text { Diario La } \\
\text { Prensa }\end{array}$ \\
\hline 1993 & $\begin{array}{l}\text { Mons. Eduardo Mirás, } \\
\text { obispo auxiliar y vicario } \\
\text { general a cargo del } \\
\text { gobierno de la } \\
\text { arquidiócesis de Buenos } \\
\text { Aires }\end{array}$ & Carlos Menem & $\begin{array}{l}\text { Buenos } \\
\text { aires }\end{array}$ & $\begin{array}{c}\text { Boletín } \\
\text { Eclesiástico } \\
\text { del Arzobisp } \\
\text { de Bs As. }\end{array}$ \\
\hline 1996 & $\begin{array}{c}\text { Cardenal Antonio } \\
\text { Quarracino, arzobispo } \\
\text { de Buenos Aires y } \\
\text { primado de la Argentina }\end{array}$ & Carlos Menem & Buenos Aires & $\begin{array}{l}\text { Boletín } \\
\text { Eclesiástico } \\
\text { del Arzobisp } \\
\text { de Bs As. }\end{array}$ \\
\hline 1999 & Mons. Jorge Bergoglio & Carlos Menem & Buenos Aires & $\begin{array}{c}\text { Pagina web de } \\
\text { AICA }\end{array}$ \\
\hline 2000 & Mons. Jorge Bergoglio & De la Rua & Buenos Aires & $\begin{array}{l}\text { Pagina web de } \\
\text { AICA }\end{array}$ \\
\hline 2001 & Mons. Jorge Bergoglio & De la Rua & Buenos Aires & $\begin{array}{l}\text { Pagina web de } \\
\text { AICA }\end{array}$ \\
\hline 2002 & Mons. Jorge Bergoglio & Eduardo Duhalde & Buenos Aires & $\begin{array}{l}\text { Pagina web de } \\
\text { AICA }\end{array}$ \\
\hline 2003 & Mons. Jorge Bergoglio & Eduardo Duhalde & Buenos Aires & $\begin{array}{c}\text { Pagina web de } \\
\text { AICA }\end{array}$ \\
\hline 2004 & Mons. Jorge Bergoglio & Néstor Kirchner & Buenos Aires & $\begin{array}{c}\text { Pagina web de } \\
\text { AICA }\end{array}$ \\
\hline 2005 & Mons. Jorge Bergoglio & Néstor Kirchner & Buenos Aires & $\begin{array}{l}\text { Pagina web de } \\
\text { AICA }\end{array}$ \\
\hline 2006 & $\begin{array}{l}\text { Mons. Rubén H. Di } \\
\text { Monte. Arzobispo de } \\
\text { Mercedes-Luján }\end{array}$ & Néstor Kirchner & $\begin{array}{l}\text { Basílica de } \\
\text { Luján }\end{array}$ & $\begin{array}{c}\text { Pagina web de } \\
\text { AICA }\end{array}$ \\
\hline 2007 & $\begin{array}{c}\text { Eduardo María Taussig, } \\
\text { obispo de San Rafael }\end{array}$ & Néstor Kirchner & Mendoza & $\begin{array}{l}\text { Pagina web de } \\
\text { AICA }\end{array}$ \\
\hline 2008 & $\begin{array}{c}\text { Mons. Mario Antonio } \\
\text { Cargnello, arzobispo de } \\
\text { Salta, en }\end{array}$ & Cristina Fernández & $\begin{array}{l}\text { Iglesia } \\
\text { catedral de } \\
\text { la ciudad de } \\
\text { Salta. }\end{array}$ & $\begin{array}{c}\text { Pagina web de } \\
\text { AICA }\end{array}$ \\
\hline 2009 & $\begin{array}{l}\text { Mon. Marcelo Raúl } \\
\text { Martorell, obispo de } \\
\text { Puerto Iguazú }\end{array}$ & Cristina Fernández & $\begin{array}{l}\text { Puerto } \\
\text { Iguazú }\end{array}$ & $\begin{array}{l}\text { Pagina web de } \\
\text { AICA }\end{array}$ \\
\hline 2010 & $\begin{array}{c}\text { Mons. Agustín } \\
\text { Radrizzani, arzobispo } \\
\text { de Mercedes-Luján }\end{array}$ & Cristina Fernández & $\begin{array}{l}\text { Basílica de } \\
\text { Luján }\end{array}$ & $\begin{array}{c}\text { Pagina web de } \\
\text { AICA }\end{array}$ \\
\hline
\end{tabular}

Cuadro 3.1: locutor, audiencia, escenario y fuente de las homilías. 


\subsection{Método y técnicas}

El diseño de la investigación

La lectura detenida del corpus descrito nos llevó a escoger un método cualitativo de análisis. Este paradigma de investigación se consideró apropiado porque, por un lado, favorece el estudio de la construcción discursiva y el modo en que se despliega la evaluación en los textos. Por el otro, permite indagar cómo se construye el discurso religioso y se promueven determinadas lecturas sobre un evento en particular. Entendemos que con las técnicas cualitativas se puede acceder a los significados sociales, culturales e ideológicos, se actúa sobre contextos reales con la participación directa del investigador. Además, con la aplicación de dichas técnicas es posible adentrarse en el campo de la subjetividad y de la individualidad. Irene Vasilachis (1992) señala que las técnicas cualitativas permiten el examen directo del mundo empírico social, con la posibilidad de observarlo y analizarlo, de generar inquietudes, recopilar información, establecer relaciones, y de analizarlo a la luz de un referente teórico para plantear alternativas para la transformación del objeto.

Con un corpus relativamente acotado, es posible realizar un análisis exhaustivo del discurso con el cual pueden identificarse aspectos que tal vez pasarían inadvertidos en un estudio estadístico de grandes corpora. Como plantean Martin y Rose (2003), es importante analizar textos individuales, ya que lo que tiene de único un texto en particular puede ser lo verdaderamente relevante. En el mismo orden de ideas, van Dijk (1990) señala que el objetivo del análisis del discurso está relacionado con la producción de descripciones textuales y contextuales del discurso: "las dimensiones textuales dan cuenta de las estructuras del discurso en diferentes niveles de descripción. Las dimensiones contextuales relacionan estas descripciones estructurales con diferentes propiedades del contexto, como los procesos cognitivos y las representaciones o factores socioculturales" (van Dijk 1990: 45). De ahí que, a partir de los resultados obtenidos se pueda llegar a determinar, por ejemplo, que la aparición o desaparición de una etapa constitutiva del género pudo estar vinculada con problemas políticos o sociales de un momento dado, o con cambios en el modo como el productor del texto deseaba posicionarse respecto 
de su audiencia. Por su parte, Fairclough (1992, 1995, 1998, 2003), importante exponente del Análisis Crítico del Discurso, propone un modelo teórico de tres dimensiones para pensar el discurso y el análisis del discurso. Este modelo tridimensional consiste en conceptualizar y analizar cualquier "evento discursivo" en términos de tres facetas o dimensiones: (i) como un texto (pieza de lenguaje escrito o hablado), (ii) como un caso de práctica discursiva que involucra los procesos de producción e interpretación de textos, y como (iii) parte de una práctica social, en términos del marco situacional e institucional del evento discursivo. Según Fairclough (2003a) el análisis del discurso tomado como texto supone un estudio lingüístico detallado del texto (o los textos) que da cuenta del modo como sus distintos rasgos (gramaticales, fonológicos, de vocabulario, de estructura global, de cohesión) producen efectos de sentido en los planos de la (inter)acción, representación e identificación (Fairclough, 2003a). Sobre la base de estas miradas al análisis del lenguaje se ha llevado a cabo el presente trabajo.

Las técnicas utilizadas para realizar el presente estudio se encuadran en el paradigma de investigación "exploratorio-interpretativo" (Grotjahn 1987, en Nunan 1992), ya que se emplea un método no-experimental para la recolección del corpus. En efecto, las homilías se dan en un ámbito y un momento dados y no son generadas por el investigador y los resultados de la investigación provienen de un análisis interpretativo de los datos. Según Hernández Sampieri (1991), el diseño del método no-experimental utilizado en este estudio es de carácter "longitudinal de tendencia", ya que la muestra se tomó durante un período de 34 años y se estudian cambios a través del tiempo (longitudinal) dentro de una población particular (tendencia). La metodología que aquí propongo surgió originalmente con el estudio de las características genéricodiscursivas de las 18 homilías que componen el corpus. La metodología cualitativa fue utilizada para llevar a cabo un análisis descriptivo diacrónico de dichos textos lo que permitió comprender el modo como este género discursivo va cambiando en el transcurso del tiempo y cómo se manifiesta la evaluación en los textos tomando en cuenta el contexto de producción. Acordamos con Cameron et al (1998, en Mills 2003)- que los ítemes de la lengua son siempre multifuncionales, y, por lo tanto, difíciles de cuantificar. La tradición cualitativa 
sostiene que el conocimiento que se obtiene por medio de la investigación es parcial (no generalizable en términos cuantitativos) situado (específico de situaciones y períodos más que aplicables en forma universal) y relativo (relacionado con la visión del mundo y el sistema de valores del investigador) (Taylor 2001, en Mills 2003). Sin embargo, entendemos que la elección de un tipo de análisis de corpus cualitativo no excluye la posibilidad de utilizar ciertas técnicas simples de cuantificación, como el cómputo de frecuencias y proporciones. Silverman (2001), entiende que estas técnicas "permiten eliminar las persistentes dudas del investigador ( $\mathrm{y}$ del lector) respecto a cuan precisas son sus impresiones sobre los datos" (Silverman (2001: 241). ${ }^{16}$ Por otro lado, el análisis cuantitativo nos ofrece información estadísticamente significativa y resultados que pueden considerarse generalizables (McEnery \& Wilson 1996: 63). Mario Bunge (1995: 3) argumenta al respecto:

No puede haber oposición entre métodos cualitativos y cuantitativos ya que cantidad y cualidad son complementarias más que excluyentes. De hecho, toda cantidad es, o bien la "numerosidad" de un conjunto de ítemes que comparten cierta cualidad, o la intensidad de una cualidad. De ahí que en el proceso de la formación de un concepto la cualidad, precede a la cantidad.(las comillas son mías).

En resumen, nuestra investigación supone las siguientes características:

- Es de corte cualitativo con la utilización limitada de datos cuantitativos.

- Los textos escritos se analizan según los procedimientos analíticointerpretativos que se utilizan en el análisis lingüístico.

- Los datos cuantitativos se han obtenido a partir de los resultados del análisis cualitativo.

- Los resultados obtenidos suponen la realización de la triangulación entre la teoría, el método y los datos.

\footnotetext{
${ }^{16} \mathrm{Mi}$ traduccion del original en ingles: "the proper use of simple tabulations can remove the researcher's (and reader's) nagging doubts about the accuracy of their impressions about the data" (Silverman 2001:241).

${ }^{17} \mathrm{Mi}$ traduccion del original en ingles: There can be no opposition between quantitative and qualitative methods, since quantity and quality are mutually complementary rather than exclusive. Indeed, every quantity is either the numerosity of a collection of items sharing a certain quality, or the intensity of a quality. Hence, in the process of concept formation, quality precedes quantity.
} 


\subsection{Procedimientos}

El modelo de género que sirvió de referencia fue, como ya se mencionó en el capítulo de marco teórico, el propuesto por la Escuela de Sydney complementado por las propuestas de otros autores que trabajan de acuerdo a los lineamientos de la LSF como Taboada (2004) y Oteíza (2006). Asimismo, se adoptó de esta perspectiva la notación empleada para indicar la fórmula genérica.

Una vez ordenados los textos se les asignó una nomenclatura que consiste en el año de producción precedido por la letra "H". Se procedió luego a numerar las líneas que para para su referencia van precedidas por la letra "l". Así el código H 1986; I 24-46 indica que la cita corresponde a la sección de la Homilía del año 1986 comprendida entre las líneas 24 y 46.

Para analizar la estructura genérica en el presente trabajo, se procedió primero a la descripción de la situación de emisión, el emisor y su audiencia. Luego nos detuvimos en la definición de la función global del género así como en la identificación del modo en que el tipo textual construye una realidad social. En este paso se definieron, entonces, las prácticas sociales a las que refiere el texto y las actitudes y valores que se forman y reflejan en él.

Una vez establecida la función global de los textos, se los segmentó de acuerdo a las etapas que componen el género y se le asignó un valor funcional a cada una de ellas. Con el propósito de ver la conformación de los textos como exponentes de un género determinado se confeccionó una primera grilla en la que se detalla la presencia o ausencia de las etapas detectadas en la totalidad de los textos.

\begin{tabular}{|c|c|c|c|c|}
\hline Homilía (año) & Motivación & $\begin{array}{c}\text { Fundamentación } \\
\text { ideológica }\end{array}$ & Evaluación & Conclusión \\
\hline H 1996 & $\mathbf{X}$ & $\mathbf{X}$ & $\mathbf{X}$ & $\mathbf{X}$ \\
\hline
\end{tabular}


Luego, se asignó un color a cada etapa y se procedió a pintar cada una de ellas en la totalidad de los textos para facilitar la visualización del espacio que cada una de ellas ocupa. Una vez contabilizadas las líneas y obtenidos los porcentajes que cada etapa representa respecto de la totalidad de cada texto, se procedió a volcar los datos a una segunda grilla con los siguientes apartados.

\begin{tabular}{|c|c|c|c|c|c|c|l|l|l|}
\hline Homilía & $\begin{array}{c}\text { Cantidad de } \\
\text { líneas }\end{array}$ & \multicolumn{2}{|c|}{ Motivación } & \multicolumn{2}{|c|}{$\begin{array}{c}\text { Fundam. } \\
\text { ideológica }\end{array}$} & \multicolumn{2}{|c|}{ Evaluación } & \multicolumn{2}{|c|}{ Conclusión } \\
\hline & & líneas & $\%$ & líneas & $\%$ & líneas & $\%$ & líneas & $\%$ \\
\cline { 3 - 10 } & & & & & & & & & \\
\hline
\end{tabular}

Este análisis nos llevó a concentrarnos en la etapa de evaluación y clasificar los textos según tengan o no dicha etapa y al porcentaje de texto que se destina a la misma. A partir de estos datos, se hizo una interpretación de los aspectos contextuales que determinan las elecciones por parte del productor del texto. Fairclough $(1992,1995)$ señala que la dimensión del discurso como práctica social da cuenta de que todo evento discursivo es parte de una práctica social y está, como tal, inserto en un conjunto de situaciones, instituciones y macrocontextos que condicionan fuertemente los usos del lenguaje. Dichos condicionantes deben considerarse en diferentes niveles de abstracción: el nivel concreto de la situación social en que el evento discursivo ocurre, el nivel institucional del cual la situación social es parte, y el nivel más amplio de la sociedad como un entramado de diversas estructuras políticas, económicas y culturales (Fairclough, 1992,1995, 2000b). Estos conceptos guían la fase de interpretación en el estudio.

Finalmente, se estableció una fórmula estructural en una secuencia lineal en la cual el símbolo ${ }^{\wedge}$ denota el orden de las etapas mientras que las etapas opcionales aparecen expresadas entre paréntesis, teniendo en cuenta que los elementos obligatorios son los que definen el género y que, por lo tanto, constituyen elementos clave en su reconocimiento.

La segunda etapa de nuestro estudio surge del interrogante planteado acerca de la evaluación en los textos. La perspectiva teórico-metodológica empleada 
para explorar el aspecto evaluativo del discurso, fue la Teoría de la Valoración (Appraisal Theory), con especial interés en el subsistema del Compromiso y elementos de la 'noción de voz' tal como la concibe (Martin, 2000). Los autores de la Teoría de la Valoración se han concentrado tanto en el análisis cualitativo de textos como en el análisis de corpus procurando encontrar una sistematicidad en la realización léxico gramatical de los significados interpersonales, entre otros, como los ideacionales, experienciales y textuales que no forman parte de este estudio.

Si bien al mencionar el método y las técnicas elegidas queda implícita la utilización de ciertas herramientas de investigación que están íntimamente ligadas a las preguntas que nos hacemos al abordar los textos, mencionamos a continuación las que consideramos más importantes al momento de realizar la evaluación. Para su descripción más acabada hemos seguido a Gee (2011).

En primer lugar, tomamos la herramienta de la Intertextualidad (Intertextuality Tool) para responder al interrogante de cómo las estructuras gramaticales de atribución de la palabra se usan para referir a otros "textos" u otros estilos de lengua o "lenguajes sociales" y si esa intertextualidad genera una mezcla o alternancia entre las voces y los "lenguajes sociales". Esta herramienta fue utilizada en una primera aproximación en que nos concentramos en la incorporación de otros discursos al discurso actual de la homilía. Para ello, nos detuvimos en el análisis de verbos de reporte y ciertos rasgos léxicos como los marcadores de evidencia así como en el posicionamiento del locutor respecto de esas voces.

La segunda herramienta que tomamos fue la de Construcción de Identidades (Identities Building Tool), con la cual intentamos responder a la pregunta sobre qué identidades reconocibles socialmente está intentando tomar el locutor para que los otros la reconozcan. También se utilizó para analizar cómo el lenguaje que usa el hablante devela la identidad que el mismo le asigna a su audiencia respecto de la propia y qué identidades les "propone" asumir. Esta herramienta nos fue de gran utilidad en el análisis de la posición del emisor respecto de su audiencia y de los recursos léxico-gramaticales que el mismo utiliza para lograr 
sus objetivos. Aquí nos detuvimos en el discurso monoglósico y heteroglósico y, dentro de este último, en los recursos de expansión y contracción dialógica.

Finalmente, para poder estudiar las expresiones de Juicio, tanto de estima como de sanción social, que se manifiestan como inscritas o implícitas, recurrimos a la herramienta de "Construcción de Relevancia (Significance Building Tool). Con esta herramienta respondimos al interrogante de cómo se utilizan las palabras evaluativas y determinadas construcciones gramaticales para construir o mitigar la relevancia de ciertos eventos y no otros y hacia quién se dirigen los valores de juicio y con qué propósito.

Para ilustrar el subsistema de Juicio se adaptaron cuadros presentados por Martin y White (2005) de acuerdo a los requerimientos de los textos en estudio.

\begin{tabular}{|l|l|l|}
\hline \multicolumn{2}{|c|}{ Juicio de estima social } \\
\hline & Valoración positiva & Valoración negativa \\
\hline
\end{tabular}

\begin{tabular}{|l|l|l|}
\hline \multicolumn{3}{|c|}{ Juicio de sanción social } \\
\hline & Valoración positiva & Valoración negativa \\
\hline
\end{tabular}

En palabras de Piñuel (2002: 2), podríamos concluir que en el presente trabajo se llevan a cabo con diferentes énfasis un "...conjunto de procedimientos interpretativos de productos comunicativos (...) que proceden de procesos singulares de comunicación previamente registrados, y que, basados en técnicas de medida, a veces cuantitativas (estadísticas basadas en el recuento de unidades), a veces cualitativas (lógicas basadas en la combinación de categorías) tienen por objeto elaborar y procesar datos relevantes sobre las condiciones mismas en que se han producido aquellos textos". Pues, en el análisis categorial, la finalidad última consiste en re-velar, "des-ocultar", indagar en el mensaje, aquello que está oculto, recóndito, implícito, velado, latente, potencial: lo no dicho. (Bardín, 1977 citado en Piñuel y Gaitán, 1995). 
A los planteos metodológicos hechos en este apartado se han agregado principios y técnicas provenientes de otras posturas según las necesidades surgidas en el análisis. 


\section{EL ESTUDIO}

\section{Introducción}

Como ya se mencionó, la ceremonia de Tedeum es parte integrante de los actos tradicionales con los que las autoridades argentinas celebran las fechas patrias. Se trata de una celebración católica, cuya finalidad es dar gracias a Dios por los acontecimientos históricos rememorados en la fiesta patria, en este caso, por la Revolución de Mayo. En esta oportunidad, habitualmente, el presidente de la Nación camina con su gabinete los 150 metros que separan la Casa de Gobierno de la Catedral Metropolitana para asistir a esta ceremonia que es generalmente oficiada por la más alta autoridad eclesiástica nacional. Como parte de esta celebración, se lee un pasaje bíblico y se pronuncia una homilía ${ }^{18}$, es decir, un discurso orientado a la explicación e interpretación de la lectura.

Es de esperar que en la homilía se haga alusión tanto a los acontecimientos históricos rememorados como así también a la situación social, histórica o política en la que se la pronuncia. Asimismo, el destinatario en esta ocasión se complejiza, puesto que se habla tanto para el pueblo argentino que sigue la celebración a través de los medios masivos, como para un auditorio particular conformado por las más altas autoridades políticas del país y representantes de otros sectores. El orador parte entonces del hecho de que, en esta ocasión, su auditorio comprende también individuos que no están familiarizados con las lecturas bíblicas ni con las prácticas religiosas habituales de la Iglesia Católica. Esta heterogeneidad exige un trabajo más minucioso en la preparación de la homilía, labor que se inicia con la selección de la lectura bíblica sobre la cual se va a predicar y que no necesariamente coincide con el calendario del culto o la

\footnotetext{
${ }^{18}$ Este género de antigua tradición se revitaliza como práctica a partir del Concilio Vaticano II. En el artículo 52 de la Constitución "Sacrosanctum Concilium" (sobre la Sagrada Liturgia) se especifica: "Se recomienda encarecidamente, como parte de la misma Liturgia, la homilía, en la cual se exponen durante el ciclo del año litúrgico, a partir de los textos sagrados, los misterios de la fe y las normas de la vida cristiana. Más aún : en las Misas que se celebran los domingos y fiestas de precepto, con asistencia del pueblo, nunca se omita si no es por causa grave."
} 
agenda bíblica, ya que en estas ocasiones la selección se hace de modo tal que sirva de sustento a los temas que el escritor/locutor desea mencionar (Arnoux y Blanco, 2002).

Dentro de la celebración de la eucaristía, la homilía forma parte del conjunto de ritos que fortalecen la identidad de la comunidad eclesial. El celebrante, al exponer la ideología de la institución que representa, busca persuadir a la audiencia acerca de la conveniencia de seguir los postulados de la doctrina cristiana presentándole el modelo a imitar.

Si bien los manuales de predicación señalan que el texto bíblico es un componente esencial que oficia como disparador de la función interpretativa y como ilustración y prueba de lo ejemplar, los textos analizados no siempre responden a este esquema. En los casos en que la homilía se estructura en torno a un pasaje bíblico perteneciente a otra época y cultura, la función del orador consiste en hacer una interpretación que conmueva, que sea significativa y relevante a la audiencia. De este modo, la interpretación dependerá de la reformulación del pasaje bíblico, lo que los manuales de predicación señalan como "actualización". El hecho de "anclar" el discurso en el presente favorece, en cierto modo, que el mismo se desplace, a menudo, hacia la reflexión política. (Maldonado, 1993 en Arnoux y Blanco 2002)

En general, como ya se dijo, quien pronuncia una homilía de Tedeum es la autoridad máxima de la Iglesia. Sin embargo, el presidente puede elegir el lugar y el celebrante. De hecho, del año 2005 en adelante, tanto el presidente Néstor Kirchner como su sucesora, la presidente Cristina Fernández de Kirchner, optan por "sacar" la celebración del Tedeum de la catedral metropolitana logrando de este modo no tener que recibir críticas por parte del arzobispo de la ciudad de Buenos Aires y Cardenal primado, Jorge Bergoglio, quien tiene una postura sumamente crítica respecto de ambas gestiones. ${ }^{19}$ En efecto, los temas abordados en sus homilías versan sobre conductas indeseadas como la

${ }^{19}$ http://radiocristiandad.wordpress.com/2008/05/13/cristina-kirchner-tambien-esquiva-homiliade-bergoglio-por-tedeum-del-25-de-mayo/ (consultado 1/5/ 2008) 
corrupción, el abuso de poder, el enriquecimiento frente al empobrecimiento del pueblo, la insensibilidad frente al dolor, la falta de creatividad para afrontar problemas etc. Sin embargo, en las homilías posteriores, celebradas en ciudades del interior, así como las anteriores a este período, se observa que las mismas son más expositivas, prescriptivas e informativas, y versan sobre temas que escapan a lo religioso, además de no presentar las partes en las que se hace una crítica abierta al gobierno de turno, como se evidencia en las homilías emitidas en la catedral metropolitana por el arzobispo de Buenos Aires.

Las homilías en estudio están presentes en los medios y, con el paso del tiempo, se han ido transformando en forma cada vez más evidente en un acontecimiento más de la celebración del 25 de mayo en el que la lglesia se expresa públicamente frente a acontecimientos coyunturales. Es una oportunidad que le ofrecen los medios para exponer su ideología y confirmar su presencia en la vida institucional de la Nación.

\subsection{La homilía de Tedeum del 25 de mayo: su función social. ${ }^{20}$}

\subsubsection{Valor comunicativo y funcional de la homilía de Tedeum del 25 de mayo.}

El espacio de producción de las homilías, objeto de análisis de este estudio, está claramente asignado por la estructura que ofrece la Iglesia Católica como institución; no obstante, cada homilía establece un modo de inserción propio en dicho espacio. En este sentido, las homilías de Tedeum apuntan principalmente a exhortar y persuadir al destinatario de que lleve a cabo una acción específica, siempre teniendo en cuenta el marco de acción de gracias en el que se emiten. Además de la reflexión espiritual, se utiliza el espacio asignado dentro de la ceremonia religiosa para denunciar conductas no deseadas o mostrar modelos a seguir dentro de la realidad circundante. De distintos

\footnotetext{
${ }^{20}$ Nota: Los textos de las homilías se reproducen tanto en el anexo como en el cuerpo del trabajo tal y como aparecen en las fuentes consultadas.
} 
modos, observamos que todas las etapas constitutivas de la homilía colaboran con esta función global.

Los actores: Emisor, audiencia, los otros.

Aldazábal (2006) apunta que la audiencia de una homilía de Tedeum está integrada, por lo general, por los bautizados pero no siempre creyentes y evangelizados. Tampoco se puede asegurar que todos los que escuchan una homilía estén catequizados. Por eso, este género, en numerosas oportunidades, deberá complementar la evangelización o la catequesis, que deberían ser pasos previos, especialmente en celebraciones extraordinarias como casamientos, bautismos o misas de Tedeum. En estos casos, deberá anunciar la salvación que Dios ofrece por intermedio de Cristo, que es la Buena Nueva, además de invitar una y otra vez a la conversión a la fe, que con audiencias tan heterogéneas, no se puede dar por sentada.

En estas homilías, el auditorio no solo está compuesto por el Presidente de la Nación, su gabinete de ministros, altos mandos de las Fuerzas Armadas, y otros funcionarios. También están dirigidas al pueblo argentino, creyentes o no, puesto que casi en su totalidad son transmitidas por los canales de televisión y se reproducen en los diarios más importantes del país. Además, a partir del año 1999, comenzaron a difundirse también por internet. Vale decir, que el auditorio es muy amplio y este hecho hace que la función de la homilía se vea modificada respecto de la de aquellas que se emiten en misas ordinarias. En estos casos, observamos que el discurso, enunciado la mayoría de las veces por actores sociales que ocupan un lugar de mayor jerarquía dentro de la estructura institucional de la Iglesia, ya sea obispos, arzobispos o cardenales, toma características del discurso político al incorporar etapas en las que el emisor proyecta un posicionamiento ideológico muy definido y su discurso se tiñe de denuncia y juicios de valor.

Prueba fehaciente de este viraje hacia la esfera del discurso político son las líneas introductorias de las homilías de los años 2007, 2009 y 2010 en las que se enumeran todas las autoridades presentes en lugar de dirigirse a los 
feligreses como hermanos y hermanas, como vemos en la apertura de la homilía del año 2005, fórmula más habitual en este tipo de evento. En la homilía del año 2007 el locutor, continuando con el espíritu político de su discurso, se dirige a las autoridades y al Pueblo todo de la Patria, mientras que en los años 2009 y 2010 el encabezado toma un formato similar con el agregado en la última de un saludo a todos los presentes y a aquellos que siguen la celebración por cadena nacional. (ver anexo)

En el año 2008, en cambio, el emisor parece atenuar la fuerte intención política detrás de la homilía atribuyendo a la Providencia la presencia de la presidente de la nación, su gabinete y otros funcionarios en dicha celebración. De este modo, se evita la enumeración de funcionarios que se da en las homilías antes mencionadas acercando el formato de discurso político al religioso.

La Providencia ha querido que Salta fuera la sede de la celebración nacional presidida por la Excelentísima Señora Presidenta de la Nación, por el gabinete que la acompaña en su gobierno, por representantes de los poderes legislativo y judicial y por el cuerpo diplomático acreditado en nuestra patria.(H2008; I 13-16)

En las homilías de los años 1980 y 1987, los locutores hacen mención de los actores presentes en la celebración ubicándolos en distintas esferas según pertenezcan al Gobierno, a la Iglesia o a las Fuerzas Armadas:

Las máximas autoridades de la nación argentina y de la ciudad de Buenos Aires, el cardenal arzobispo primado y sus obispos auxiliares, los representantes de las naciones hermanas y los uniformes de las Fuerzas Armadas para la defensa de la patria-se posternan devotamente ante el cristo rey de la historia, tal cual lo vienen haciendo desde nuestro nacimiento como pueblo anheloso de libertad en 1810 y luego jurídicamente independiente en 1816, para dar gracias a Dios. (H 1980; I 27-32)

Aquí estamos hoy, ante nuestro señor, representantes del Gobierno y de la Iglesia, dos realidades, una política y otra sobrenatural y misteriosa. En rigor, representantes de dos aspectos de una misma realidad que es el Hombre... $(\mathrm{H}$ 1987 ; $65-67$ )

En el entrecruzamiento constante entre aspectos que obedecen al discurso religioso y al discurso político que se observa en los textos, nos hemos 
detenido en la elección de la primera persona tanto del singular como del plural que hace el emisor, para ubicarse en solidaridad o confrontación respecto de su audiencia. En la homilía del año 2004, el celebrante, tomando como punto de partida la lectura bíblica, denuncia a la clase dirigente desde la primera persona del singular pero atenuando la denuncia con la frase me parece:

Jesús, fiel al estilo profético que acompañaba su paso entre los hombres, realiza gestos simbólicos, ¿qué significa este dejar Nazaret su "patria"? Me parece ver aquí una fuerte protesta contra los que se sienten tan incluidos que excluyen a los demás. Tan clarividentes se creen que se han vuelto ciegos, tan autosuficientes son en la administración de la ley que se han vuelto inicuos. $(\mathrm{H}$ $2004 ; \mid 58-64)^{21}$

Del mismo modo, en la homilía del año 1996, el celebrante vuelve a hacer una denuncia en primera persona del singular, y nuevamente su posicionamiento polémico se atenúa con la construcción me pregunto:

Me pregunto si no sería bueno que los partidos políticos, todos, tradicionales o no, hayan ejercido o no el poder en alguna área del mismo, se preguntaran hasta dónde fueron instrumentos positivos para el bien de la sociedad entera, dejando de lado los intereses particulares y tratando de insuflar esfuerzos $y$ sacrificios alejándose siempre de la demagogia, con promesas a veces cómicas, la mentira , y el favoritismo y los slogans y frases hechas tan engañosos como partidistas, cuando no ideologizados.(H 1996; I 45-50)

En la homilía del año 2002, el locutor advierte acerca de cómo la deshonestidad de la clase dirigente (ellos) afecta al nosotros construido desde el púlpito:

Que no nos corten caminos las calculadoras intransigencias (en nombre de coherencias que no son tales). Que no sigamos revolcándonos en el triste espectáculo de quienes ya no saben cómo mentir y contradecirse para mantener sus privilegios, su rapacidad y sus cuotas de ganancia mal habidas, mientras perdemos nuestras oportunidades históricas, y nos encerramos en un callejón sin salida.(H2002; 93-97)

En el año 1999, el orador nuevamente hace mención a un ellos, blanco de críticas y denuncias, y a un nosotros que no coincide con el auditorio presente, sino que lo construye fusionando a la Iglesia y al pueblo argentino.

\footnotetext{
${ }^{21}$ Nota: En todos los ejemplos del presente análisis, el resaltado en negrita se agrega cuando es necesario señalar aspectos a los que la descripción se refiere.
} 
Los argentinos marchamos por nuestra historia acompañados por el don creado de las riquezas de nuestras tierras y por el Espíritu de Cristo reflejado en la mística y el esfuerzo de tantos que vivieron y trabajaron en este Hogar, en el testimonio silente de los que dan de su talento, su ética, su creatividad, su vida(...) Porque somos un pueblo capaz de sentir nuestra identidad más allá de las circunstancias y adversidades, somos un pueblo capaz de reconocernos en nuestros diversos rostros. Tanto talento no siempre se ha visto acompañado por proyectos con continuidad en el tiempo, ni logró convocar siempre la conciencia colectiva. Y, por ello, como los discípulos huidizos, podemos encontrarnos acaparados por cierta amargura en nuestra marcha, fatigados por problemas que no dejan vislumbrar la urgencia de un futuro que nunca parece llegar. (H 1999; I 58-71)

En el extracto anterior el locutor, posicionándose en solidaridad con los ciudadanos, hace una valoración altamente positiva del pueblo, digno de elogio, que padece la deshonestidad, corrupción y el abuso de poder por parte de la clase dirigente

En otras homilías, el pueblo es mencionado en tercera persona pero siempre se lo trae tanto para oponerlo a la actitud negativa de quienes se critica, como podemos apreciar en la homilía del año 2001 o para destacar sus virtudes, como se hace evidente en las homilías de los años 2003 y 2004 :

Nuestro pueblo lo bebe diariamente en el servicio de millones de personas que silenciosamente ponen el cuerpo al trabajo o a la búsqueda de él y no a la especulación, en el servicio de los que sostienen la convivencia y solidaridad callada y no los absurdos fantasmas de xenofobia propios de minorías ideológicas agitadoras de conflictos, en el servicio de los que -sufriendo la globalización de la pobreza- no han dejado de igualarse en la solidaridad de organizaciones comunitarias y manifestaciones culturales, espontáneas y creativas. Todos estos, mujeres y hombres de nuestro pueblo, que rechazan la desesperanza y se rebelan contra aquellas mediocridades, quieren decirle no a la anomia, no al sinsentido y a la superficialidad fraudesca (cuando no farandulera) que alienta el consumismo. $Y$ no, en fin, a quienes necesitan un pueblo pesimista y agobiado de malas noticias para obtener beneficios de su dolor. (H 2001; I 69-80)

El pueblo de nuestra Nación demuestra, una y otra vez, la clara voluntad de responder a su vocación de ser buenos samaritanos unos con otros: ha confiado nuevamente en nuestro sistema democrático a pesar de sus debilidades y carencias, y vemos cómo se redoblan los esfuerzos solidarios para volver a tejer una sociedad que se fractura. Nuestro pueblo responde con silencio de Cruz a las propuestas disolutorias y soporta hasta el límite la violencia descontrolada de quienes están presos del caos delincuencial. $(\mathrm{H}$ 2003; | 102-107) 
Pero gracias a Dios, nuestro pueblo también conoce el camino humilde del machacar diario, el mismo de tantos años de vida oculta. El de apostar al bien y sostener sin estar seguros del resultado. Conoce el silencio dolorido y pacífico pero - a la vez- rebelde, de muchos años de desencuentros, promesas falsas, violencias e injusticias expoliadoras. Sin embargo, encara diariamente sus tareas, con mucho desgaste social y un tendal de marginaciones. Año a año renueva su confiada espera marchando peregrino a tantos lugares donde Dios y su Madre lo esperan para el diálogo reconfortante, fortalecedor. $(\mathrm{H} 2004$; I 202-208)

En la homilía del año 2000 hemos notado, sin embargo, que el locutor se identifica mediante el uso de la primera persona del plural ya no con el pueblo sino con el auditorio presente que es el que tiene el poder de llevar a cabo el cambio que se está planteando:

$Y$, nosotros, animémonos a tocar: a tocar al marginado del sistema, viendo en él a hombres y mujeres que son mucho más que votantes potenciales. En el marco de las Instituciones republicanas demos poder y apoyo a aquellas organizaciones comunitarias que estrechan las manos y hacen participar, que privilegian la intimidad, la fraternidad, la lealtad a los principios y objetivos como una nueva "productividad". Así los jóvenes recuperarán horizontes concretos, descubrirán los futuros posibles dejando de lado enunciados vacíos, que ahondan las propias vaciedades. (H 2000; I 92-100)

Aquí, el incluirse entre aquellos que deben hacer un esfuerzo para mejorar las condiciones de vida implica su compromiso personal y, de este modo, agrega peso a sus palabras.

Como ya dijimos, en la predicación, se habla siempre de algo fundamental como es el camino para lograr la salvación del alma. A medida que se va desarrollando la exposición, se van identificando momentos en los que se persiguen distintos objetivos ya sea el de enseñar, conmover, criticar, denunciar, interpelar a la audiencia, y dialogar con Dios a través de la plegaria. En todo momento, el discurso se adapta a las expectativas de una audiencia heterogénea.

En el siguiente ejemplo, tomado de la Homilía del año 1979 se hace mención al espíritu de agradecimiento que convoca a los presentes.

Al celebrar un nuevo aniversario de la gran gesta de mayo nos hemos vuelto a reunir en esta histórica Iglesia Catedral para agradecer a Dios nuestro Señor 
los innumerables beneficios con que él ha colmado a nuestra querida patria Argentina.

¿Y como podría ser de otra manera?

De norte a sur, de este a oeste la extensión y fecundidad de su suelo, la variedad y la abundancia de sus recursos naturales, la belleza de sus paisajes, la benignidad de sus climas y sobre todo la capacidad y laboriosidad de sus habitantes son algunos de los tantos dones con que Dios en su bondad previsora ha bendecido nuestra patria.

Nunca habremos agradecido a Dios suficientemente por todos los bienes que, conciente o inconcientemente, a veces, disfrutamos. Por eso vamos a escuchar el Tedeum, el Himno de Acción de Gracias. Por eso vamos a oír "llenos están los cielos y la tierra de la majestad de tu Gloria, Padre de inmensa potestad". (H 1979; I 2-13)

En el fragmento tomado del año 1980, la atención está puesta en explicar la celebración de Pentecostés y la misión de la Iglesia en la historia del hombre

En el calendario de este año1980 coinciden la celebración litúrgica de Pentecostés y el 170 aniversario de nuestro grito patrio de libertad. Pentecostés es la efusión del Espíritu Santo sobre la Iglesia redimida por la sangre preciosa de Jesús salvador. Para usar una analogía así como las grandes obras de ingeniería llevan largos años de preparación-factibilidad, proyectos, construcción-hasta que llega el día solemne de su inauguración y puesta en marcha, algo así ocurre con la Iglesia, pueblo de Dios, pacientemente preparada y construida por Jesucristo durante su vida mortal.

Cuando Él retorna al Padre, envía al Espíritu Santo quien justamente pone a la Iglesia en actividad misionera para todo el tiempo que dura la historia humana, hasta que él vuelva al final de los tiempos para juzgar a los vivientes y a los muertos, a personas y a pueblos, como centro y Rey de la Historia, Sol indeclinable de la creación, Lucero indefectible en la noche de los tiempos. Como lo proclama con tanto lirismo el pregón pascual: "Cristo es ayer y hoy, es el principio y el fin, es la $A$ y $Z$, a quien sean el honor y la gloria, de quien son el tiempo y su historia, por los siglos de los siglos". (H 1980; I 2-15)

En las homilías de los años 1979 y 1993, se expresan conceptos canónicos acerca de la necesidad de Dios y de la religión para lograr objetivos tales como la paz, expresado en el primer párrafo reproducido a continuación o para hacer Patria en la homilía del año 1993:

Hermanos míos en Nuestro Señor Jesucristo: esta paz, que todos anhelamos, que todos queremos exige de nuestro esfuerzo, de nuestro sacrificio pero también exige comprender que sin la ayuda de Dios, con las solas fuerzas humanas no la podemos logar. Cristo es el Príncipe de la Paz. Por ello al unir nuestros corazones argentinos para agradecer al Creador y Padre todos los bienes que nos dio, al celebrar gozosamente y reconocidos aquella gesta gloriosa de nuestros próceres, el 25 de mayo de 1810, pidamos al divino Redentor la paz que él mismo nos trajo. Pidamos que Él borre de los hombres 
todo lo que pueda poner en peligro esta paz y transforme a todos en testigos de la verdad de la justicia y del amor fraterno.( H. 1979;l 51-59)

Por eso, en la noble tarea de legislar es preciso tener presente que no se puede hacer Patria sin atender a la ley del Señor. Nos dice Isaías que la Nación que no se someta a Dios será arruinada (Is. 60,12). (H 1993; I 76-78)

Temas y expresiones lingüísticas recurrentes.

Como ya señalamos anteriormente, si bien el discurso religioso propone la salvación, el arrepentimiento y reparación del daño hecho, las homilías más polémicas - especialmente las emitidas entre los años 1999 al 2004 por el cardenal Jorge Bergoglio en la catedral metropolitana - adoptan más claramente aspectos del discurso político ya que se manifiesta la crítica y denuncia de los aspectos negativos de los otros. En la homilía del año 2002, se hace referencia a la clase dirigente, que también es destinataria del mensaje:

Un triste pacto interior se ha fraguado en el corazón de muchos de los destinados a defender nuestros intereses, con consecuencias estremecedoras: la culpa de sus trampas acucia con su herida y, en vez de pedir la cura, persisten y se refugian en la acumulación de poder, en el reforzamiento de los hilos de una telaraña que impide ver la realidad cada vez más dolorosa. Así el sufrimiento ajeno y la destrucción que provocan tales juegos de los adictos al poder y a las riquezas, resultan para ellos mismos apenas piezas de un tablero, números, estadísticas y variables de una oficina de planeamiento.(H 2002; I 3642) y sigue: Debemos reconocer con dolor que, entre los propios y los opuestos hay muchos Zaqueos ${ }^{22}$, con distintos títulos y funciones; Zaqueos que intercambian papeles en un escenario de avaricia casi autoritaria, a veces con disfraces legítimos.(H 2002; líneas 109-111)

Estos deslizamientos hacia el discurso político no se limitan a la descalificación del otro sino que también toman forma de llamado de atención y advertencia acerca de las consecuencias que traerán esas conductas indeseables que perjudican a todos:

\footnotetext{
${ }^{22}$ Zaqueo fue tomado de la lectura para mostrar el prototipo del hombre rico, autosuficiente y avaro.
} 
Cuando el peligro de la disolución nacional está a nuestras puertas, no podemos permitir que nos arrastre la inercia, que nos esterilicen nuestras impotencias o que nos amedrenten las amenazas. (H 2002; líneas 82-84)

También la función de la homilía se ve expresada en la plegaria por la que se opta cuando la intención del emisor no es la de confrontar. Coincidiendo con los lineamientos de reconciliación planteados desde la misma Iglesia en el período de transición de dictadura a democracia, en la homilía del año 1980 el celebrante vuelve a unirse a la audiencia con un nosotros amplio que lo incluye, y se dirige a Dios en forma de oración.

Te damos gracias por el espíritu de reconciliación nacional-aún inconclusa y siempre en construcción- jurada en 1860 y que se encuentra expresada en el frontispicio de esta catedral en aquella escena de los hijos de Jacob reconciliándose entre sí tras sus querellas, ofensas y equivocaciones. Te damos gracias por la mediación providencial del Santo Padre Juan Pablo II, y te imploramos que conduzcas su gestión de paz al éxito anhelado por todos. (H1980; | 91-96)

Y continúa con un reconocimiento de culpas, necesario para recibir el perdón dentro de la concepción religiosa de reconciliación.

Te pedimos perdón por nuestras luchas entre hermanos, por la larga lista de reyertas fratricidas. Te pedimos perdón por nuestros períodos negros y rojos, por los accesos de ferocidad que periódicamente nos atacan y entenebrecen. Volvemos a darte gracias porque siempre nos das la oportunidad de reaccionar a tiempo, porque no nos castigas como merecemos por nuestras culpas sino que, cual padre amante, nos das aquel "una vez más" que nos rehabilita y redime.( H 1980; | 82-87)

Otro aspecto característico del discurso religioso es la reiteración de expresiones deónticas, que se manifiestan mediante el uso de perífrasis verbales del tipo "hay que", "ha de", "tener que" entre otras, expresadas en tercera persona o primera persona del plural y que aportan significados referidos a la obligación o necesidad (Gómez Torrego, 1997). Con dichas expresiones se deja en claro la conducta que se deberá seguir de acuerdo a los preceptos expresados en diferentes etapas de la homilía.

Pero, es indudable también que a la actitud agradecida ha de corresponder también la firme voluntad de hacer desarrollar, cada uno desde su propio rol y según sus posibilidades, las enormes potencialidades espirituales y materiales que el mismo Dios nos ha encomendado como vocación. (H1979;l 14-17) 
Y es obligación de todos el cumplimiento de la ley justa. Para ello, San Pedro en su primera carta nos aconseja ser obedientes a toda autoridad humana, por respeto al Señor (cnf. I Pe.2,13). (H 1993; 1127-129)

Después de Dios, nos enseña Santo Tomás de Aquino, el hombre en el orden natural está obligado y es deudor a sus padres y a su patria. $(\mathrm{H}$ $1976 ;$ I 12-13

"Tenemos que ser capaces de comprometernos, de alzar nuestra voz al cielo en una expresión de corazón sincero. Nuestra capacidad en un "manos a la obra". Trabajemos para que esa Paz se logre por la Paz que nace de un corazón nuevo. Todos debemos ser artífices de la Paz, con creatividad, renuncia y sacrificio."(H 1987; I 44-48)

Con la misma intención de marcar lo imperioso de llevar a cabo una acción determinada se utiliza también muy frecuentemente el imperativo en primera persona del plural, que morfológicamente coincide con el presente del subjuntivo, en el que el locutor queda incluido (Gómez Torrego, 1997). No existe por parte de la audiencia ni del celebrante la posibilidad de rechazar la invitación emanada de la autoridad eclesiástica, representante de Dios en la tierra:

Hoy, en el día de la Patria, demos gracias a Dios por ella y aprendamos la lección de esta palabra de Dios que meditamos: aprender, en la caridad, a rezar siempre a Dios por todos, uniéndonos a Dios por medio de la oración confiada para obtener la paz y la quietud en los corazones de cada uno, argentinos por nacimiento $o$ adopción, para que esa paz y quietud sea reflejada en nuestra sociedad (H 2006; I 67-71)

Además de los recursos ya mencionados, el efecto deóntico también se pone de manifiesto mediante el uso de afirmaciones categóricas, presentes en todos los textos.

El tiempo pascual es un llamado a renacer de lo alto. Al mismo tiempo es un desafío a hacer un profundo replanteo, a resignificar toda nuestra vida -como personas y como Nación- desde el gozo de Cristo resucitado para permitir que brote, en la fragilidad misma de nuestra carne, la esperanza de vivir como una verdadera comunidad. (H 2003; I 20-23).

La Iglesia, que es madre en el orden sobrenatural, siempre ha inculcado el verdadero amor a la patria siguiendo los ejemplos de N.S. Jesucristo, quien, además de amar profundamente a la patria terrena, se sometió a sus leyes. (H. 1976; I 27-30) 
Cabe aquí mencionar que todas las manifestaciones de discurso político que encontramos en las homilías analizadas siempre quedan ubicadas dentro del marco religioso del género. Se vuelve a la lectura bíblica, al magisterio de la Iglesia y a otras citas que remiten a conceptos que aportan claridad, complejidad o simplemente variedad a la explicación que se desarrolla en el discurso exegético.

Los deberes con Dios y con la Nación, nunca deberían entrar en conflicto. Saber que la Patria de un hombre no es su Dios, encauza el amor por ella y aleja la tentación de los nacionalismos ciegos y extremos, que son violencia; y la torpeza moral de la falsa prudencia que quiere cohonestar en la legislación, cualquier novedad en las costumbres sin juzgar su valor ético, como si el orden moral que la ley expresa, no fuera más que una formalidad. Tomás de Aquino enseña que la violencia del poderoso y la falsa prudencia del sabio corrompen la justicia. (H 1993; I 66-72)

Por esas razones el Concilio Vaticano II enseña que los ciudadanos deben cultivar, con magnanimidad y lealtad el amor a la patria, pero sin estrechez de espíritu, de modo que al mismo tiempo siempre miren por el bien de toda la familia humana (Cfr. G.S.75) e insiste que ese amor a la patria debe ser verdadero y eficaz (Cfr. A. G.15), de modo que en los cristianos su originalidad de ser hombres nuevos nacidos en Cristo debe manifestarse en la cultura $y$ tradiciones de su propia nación (Cfr. A. G. 21)."( H 1976; I 46-51)

Sin embargo, también hemos notado, que según el momento histórico en que la homilía es emitida y el lugar elegido por las autoridades para la celebración de la misa de Tedeum, la misma puede reflejar posturas diferentes y, siguiendo la intención del discurso político, orientar la función ya no hacia la crítica sino al elogio. Parecería que lo que el celebrante está leyendo hubiera sido escrito por el mismo gobierno pero que al ser pronunciado desde el púlpito cobra un carácter superior o sobrenatural, como si el poder político necesitara de la aprobación de la Iglesia para poner de manifiesto que su obrar se condice con los preceptos cristianos. Para decirlo en otras palabras, en algunas homilías, la Iglesia parece estar dando su bendición al accionar acertado del gobierno a quien se debe agradecimiento por las medidas tomadas. Clara prueba de ello, es la homilía del año 2005 en el primer Tedeum celebrado fuera de la catedral de Buenos Aires. Las autoridades eligen estratégicamente la provincia de Santiago del Estero ya que había sido intervenida unos meses antes, liberando al pueblo santiagueño del gobierno dictatorial del gobernador Juárez y su 
esposa. Este hecho histórico hace que haya allí un profundo agradecimiento de los habitantes de esa provincia que es explícitamente mencionado en una homilía compuesta por grandes fragmentos que no pudimos identificar con ninguna etapa constitutiva del género que nos ocupa; de hecho podría identificarse con un discurso emitido por un funcionario provincial:

También nos digna esta presencia de la Nación en este día, en esta etapa de la historia de Santiago. Hoy gozamos del funcionamiento de las instituciones democráticas elegidas por el pueblo soberano y juez. Esto es un fruto madurado por el mismo pueblo santiagueño que se puso de pie para reclamar justicia, cansado de años de arbitrariedad. (H 2005; $52-55)$

Función global

Del estudio realizado se desprende que la función global de las homilías es persuadir y exhortar tanto a la audiencia presente en la celebración así como al pueblo argentino a que actúe en concordancia con los preceptos emanados de la doctrina de la Iglesia. Asimismo, la Iglesia utiliza a la homilía para hacer presente su voz en los medios y, utilizando estrategias más cercanas al discurso político, se propone hacer oír la denuncia cuando el poder político no procede de acuerdo a los valores cristianos o el elogio según el contexto de situación en que se lleva a cabo la celebración. No hay lugar a dudas de que se trata de un género claramente religioso en el que se utilizan recursos del discurso político con el propósito de llegar a una audiencia presencial que, en su mayoría, pertenece a este ámbito.

\subsection{Etapas constitutivas}

Una vez establecida la descripción de la función global de las homilías de Tedeum, nos centraremos ahora en las distintas partes que constituyen el texto.

Siguiendo a Martin y Rose (2003, 2008), Eggins y Slade (1997) y Taboada (2004), un texto dado se percibe como perteneciente a un género por sus características estructurales, es decir, por las etapas que lo componen, y que 
dichas etapas están determinadas por su función en relación con la totalidad del texto en una situación dada. Ilustraremos las etapas que se manifiestan en todas las homilías de Tedeum analizadas y, por lo tanto, consideradas de carácter obligatorio: se trata de la motivación, la fundamentación ideológica, la evaluación y la conclusión. Asimismo, nos referiremos a lo que resulta optativo en algunos textos.

\subsubsection{La motivación}

La primera etapa identificada a la que nos vamos a referir es la motivación. Su función es iniciar el texto y dar a conocer las razones que llevan a emitir ese texto; en este caso, se trata de la conmemoración de la formación del primer gobierno patrio el 25 de mayo de 1810 con la celebración de una misa de acción de gracias (Te Deum). La motivación es utilizada como apertura en la mayoría de los casos, aunque, como pudimos ver en las homilías analizadas, puede también manifestarse en varias secciones a lo largo del texto:

... Como aquel día que hoy rememoramos en que la comuna se constituyó en Cabildo ... ( H 2002; I 143-144)

En esta etapa, se hace una breve reseña histórica de la fecha que se conmemora y el espíritu que inspiró a los próceres de Mayo así como las razones por las cuales se lleva a cabo dicha celebración de acción de gracias. Suele realizarse una reflexión acerca del concepto de patria y la íntima relación existente entre la identidad del ser nacional y el ser católico. En esta homilía se emiten juicios de valor positivo hacia los próceres de mayo y, mediante recursos de Apreciación positiva se evalúan objetos y constructos abstractos: la gesta de Mayo, la declaración de la Independencia, y al mismo Dios que al considerarse una entidad también puede ser evaluado en términos de Apreciación.

Celebramos el 166 aniversario de la gloriosa gesta de Mayo, cuando a pocos metros de esta histórica Catedral, nuestros próceres valientemente dieron los primeros y decisivos pasos del proceso de la emancipación, que madurado en la Asamblea del año XIII, culminó con la heroica declaración de la Independencia el 9 de julio de 1816. 
En este 25 de mayo, día de júbilo nacional, en que conmemoramos la gestación de nuestra patria independiente, nos hemos reunido, según una antigua y cristiana tradición, para entonar un himno de acción de gracias a Dios, pues Él es la fuente de todo bien, y por tanto también de este gran beneficio que es para el hombre su patria. (H 1976; I 1-8)

En el fragmento anterior, vemos que en el comienzo de la homilía se deja en claro la razón por la cual se está oficiando la celebración religiosa del Tedeum. En la misma, se explica la tradición cristiana de dar gracias a Dios por la patria independiente que comienza a gestarse el 25 de mayo de 1810 y se evalúa positivamente a las personas involucradas en dicha gesta, y a Dios, a quien se agradece por ser la fuente de todo lo ocurrido.

En el año 1993, además de los hechos que se conmemoran, el celebrante llama, mediante un interrogante, a la reflexión acerca del amor a la patria y a Dios:

La conmemoración del 25 de mayo vuelve a reunirnos en la catedral de Buenos Aires, testigo de la historia nacional, acaso con la esperanza de oír en este antiguo recinto el eco de aquellas jornadas de 1810.

Al venir a dar gracias a Dios por estos 183 años de emancipación, surge en nuestro interior una pregunta liminar: ¿Qué honramos al honrar a la Patria? Sentimos por ella una profunda pasión, tan nítida, que nunca se confunde con los otros amores que llevamos en el alma. Lo intuimos único y sabemos que, en la común escala de valores de todo ciudadano, está más allá de los otros sentimientos, relacionado inmediatamente con el mismo amor a Dios, como toda virtud reuniendo la multiplicidad de bien querer que brindamos a los demás.( H 1993;l 1-10)

Como dijimos anteriormente, en la mayoría de las homilías analizadas, la etapa de motivación cumple la función de apertura. En el fragmento tomado de la homilía del año 1976, vemos cómo el celebrante utiliza esta etapa para justificar la celebración y para exponer principios que son comunes a todos los presentes. Del mismo modo, en la apertura de la homilía del año 1979, el celebrante, con un discurso colmado de recursos tanto de Juicio, para evaluar la capacidad y laboriosidad de la gente como de Apreciación, para evaluar los recursos naturales, los paisajes, y belleza de la Argentina, convoca a la audiencia a dar gracias a Dios, a quien no se agradece suficientemente por los bienes recibidos. 
Al celebrar un nuevo aniversario de la gran gesta de mayo nos hemos vuelto a reunir en esta histórica Iglesia Catedral para agradecer a Dios nuestro señor los innumerables beneficios con que él ha colmado a nuestra querida patria Argentina.

¿Y como podría ser de otra manera?

De norte a sur, de este a oeste la extensión y fecundidad de su suelo, la variedad y la abundancia de sus recursos naturales, la belleza de sus paisajes, la benignidad de sus climas y sobre todo la capacidad y laboriosidad de sus habitantes son algunos de los tantos dones con que Dios en su bondad previsora ha bendecido nuestra patria.

Nunca habremos agradecido a Dios suficientemente por todos los bienes que, consciente $o$ inconscientemente, a veces, disfrutamos. Por eso vamos a escuchar el Tedeum, el Himno de Acción de Gracias. Por eso vamos a oír "llenos están los cielos y la tierra de la majestad de tu Gloria, Padre de inmensa potestad". (H1979; I 1-12)

Contrariamente a lo observado en el fragmento anterior, en la etapa de motivación de la homilía del año 1996 el locutor inicia el texto exponiendo, mediante afirmaciones categóricas y sin ningún tipo de evaluación, la razón de la celebración: recordar los acontecimientos de mayo.

Estamos recordando el centésimo octogésimo sexto aniversario de los acontecimientos de mayo cuando se dieron los primeros pasos para el ingreso argentino en el listado de las naciones libres. Ello aconteció y definitivamente el 9 de julio de 1816. (H 1996; 1 1-3)

En la homilía correspondiente a la celebración de 1980, la etapa de motivación también aparece tanto en la apertura (líneas 1 a 3) como más adelante en el texto (líneas 25 a 32) pero se utiliza para establecer un paralelo, debido a la coincidencia de fechas, entre el aniversario del primer gobierno patrio y la celebración de Pentecostés.

En el calendario de este año1980 coinciden la celebración litúrgica de Pentecostés y el 170 aniversario de nuestro grito patrio de libertad. Pentecostés es la efusión del Espíritu Santo sobre la Iglesia redimida por la sangre preciosa de Jesús salvador. (...)

Parécenos que esta escena se repite en esta solemnidad de Pentecostés y 25 de mayo bajo las bóvedas de esta histórica catedral. Las máximas autoridades de la nación argentina y de la ciudad de Buenos Aires, el cardenal arzobispo primado y sus obispos auxiliares, los representantes de las naciones hermanas y los uniformes de las Fuerzas Armadas para la defensa de la patria, se posternan devotamente ante el Cristo rey de la historia, tal cual lo vienen haciendo desde nuestro nacimiento como pueblo anheloso de libertad en 1810 y luego jurídicamente independiente en 1816, para dar gracias a Dios. $(\mathrm{H}$ $1980 ;$ I $2-4$ (...) 25-32) 
Si bien las homilías mencionadas, abren con la motivación, en aquellas de los años 1987 y 2001 esta etapa no inicia el texto, quedando desplazada al interior del mismo, con la particularidad de la homilía de 1987 que inicia con una cita bíblica y en la que, una y otra vez, se hace mención al motivo de la celebración a lo largo del texto: líneas 13 a 19; 65-67 y 71-72:

Hoy 25 de mayo, venimos para agradecer por nuestra Patria, que se fue configurando a partir de ese grito de libertad, en ese emprender un camino de autonomía, siendo forjadores y dueños de un propio destino...

Un destino de grandeza, que no rechaza ni se rebela con actitudes inmaduras contra una rica tradición recibida, sino que quiere asumirla y proyectarla hacia un futuro..., pero con libertad y la responsabilidad del que se siente dueño de una historia que nace, y es a partir de ese momento que se escribirán las grandes páginas de nuestra Patria.( H 1987; I 13-20)

Aquí estamos hoy, ante nuestro Señor, representantes del Gobierno y de la Iglesia, dos realidades, una política y otra sobrenatural y misteriosa. En rigor, representantes de dos aspectos de una misma realidad que es el Hombre. $(\mathrm{H}$ $1987 ;$ | 65-67)

Festejamos hoy el nacimiento de nuestra Patria, y es importante que reflexionemos y revaloricemos el concepto de Patria. (H 1987; I 71-72)

Por otro lado, en la homilía del año 2001 la apertura corresponde a un primer comentario acerca de la lectura bíblica elegida para la celebración y se hace una muy breve mención al motivo patrio:

En este día de la Patria, quiero detenerme en la enseñanza del Señor: "el que quiera ser grande que se haga servidor de Ustedes; y el que quiera ser el primero que se haga su esclavo: como el Hijo del Hombre, que no vino para ser servido sino para servir..."(Mt 20,26-28) (H 2001; I 24-27)

Como señalamos con anterioridad, además de exponer las razones por las cuales se celebra el Tedeum, en algunos casos se menciona en forma explícita la audiencia. En la homilía del año 1980, última del período de la dictadura militar, se hace una enumeración de las autoridades presentes que se cierra con la mención, no de los miembros sino de los uniformes de las Fuerzas Armadas para la defensa de la patria, que eran gobierno en esa celebración. 
Parécenos que esta escena se repite en esta solemnidad de Pentecostés y 25 de mayo bajo las bóvedas de esta histórica catedral. Las máximas autoridades de la nación argentina y de la ciudad de Buenos Aires, el cardenal arzobispo primado y sus obispos auxiliares, los representantes de las naciones hermanas y los uniformes de las Fuerzas Armadas para la defensa de la patria, se posternan devotamente ante el Cristo rey de la historia(...) (1980;1 25-30)

En cuanto a las homilías de los años 2007, 2009 y 2010, las mismas presentan un formato nuevo respecto de los textos anteriores analizados, puesto que el celebrante inicia su alocución enumerando a las autoridades presentes. Este hecho nos da la pauta del entorno de situación en el que se emite el texto así como la relevancia que el celebrante da a la audiencia presente que lo eligió para presidir la celebración. Hay, en estas líneas un indicio del reconocimiento, e indirectamente, de agradecimiento por parte del locutor. Reproducimos a continuación las líneas introductorias de las homilías mencionadas:

Sr. Presidente de la Nación y Sra. de Kirchner

Sr. Gobernador de la Provincia de Mendoza y Sra. de Cobos

Sr. Vicepresidente de la Nación

Sres. Presidentes de ambas cámaras legislativas de la Nación

Sres. Gobernadores

Sr. Nuncio Apostólico y Decano del Cuerpo Diplomático, S.E.R. Mons. Adriano

Bernardini

Sres. Embajadores

Autoridades Nacionales, Provinciales y Municipales

Pueblo todo de la Patria (H 2007; 4-12)

Señora Presidenta de la Nación

Señor Gobernador de la provincia de Misiones

Señor Intendente de la ciudad de Puerto Iguazú

Señores miembros de los Poderes Ejecutivo, Legislativo y Judicial

Señores Jefes de las Fuerzas Armadas y de Seguridad

Señor Nuncio Apostólico

Señores miembros del Cuerpo Diplomático en la Argentina

Señores representantes de Instituciones

Hermanos y hermanas (H 2009; 4 4-12)

Y continúa esta enumeración con:

Hoy se han reunido aquí las más altas autoridades del país, acompañadas por el cuerpo diplomático de naciones hermanas, ministros y representantes de otros credos y el pueblo de lguazú. Desde esta casa de oración, desde otras catedrales a lo ancho y largo del país y desde los hogares, nos unimos todos los que creemos en Dios y tenemos una visión trascendente de la vida para dar gracias a Dios, para presentarle nuestra realidad, nuestras necesidades. A Él confiamos nuestro futuro y le pedimos que nos bendiga para que sepamos encontrar los caminos que hagan grande a nuestra patria. 
Nos hemos reunido para rezar por la Argentina y por todos los que en ella habitan. (H 2009; líneas 22-30)

Señora Presidenta de la Nación Dra. Cristina Fernández de Kirchner, Excelentísimos Señores Presidentes de países amigos,

Su Excelencia Reverendísima Señor Nuncio Apostólico, Enviado Extraordinario de Su Santidad Benedicto XVI en Misión Especial para participar en los Actos Centrales de la Conmemoración de la Revolución de Mayo, Queridos hermanos en el Señor.

Al comenzar esta reflexión con ocasión del acontecimiento histórico para nuestra patria que conmemora los 200 años de su nacimiento, entre este 25 de mayo de 2010 y el 9 de julio de 2016, quiero dar un saludo especial a todos los presentes y a aquellos que nos siguen por cadena nacional, de parte de mis hermanos obispos, que desde todas las catedrales de la Argentina, dan gracias a Dios por este aniversario. (H 2010; | 1-13)

Vemos en la homilía del año 2009 que se menciona no sólo a los presentes, sino que se unen a la celebración, desde otras catedrales del país y desde los hogares, todos los que tienen una visión trascendente de la vida. Lo mismo ocurre en la homilía del año 2010, que el celebrante, en primera persona expresa su deseo de dar un saludo especial, en nombre de los obispos, a todos los presentes y a aquellos que nos siguen por cadena nacional.

A pesar de considerarla una etapa obligatoria del género, hemos observado que en la homilía del año 2002, la misma no está presente. A pesar de ello, podríamos pensar que el emisor da por sentado como conocimiento compartido el hecho de que la celebración se realiza conmemorando el 25 de mayo y que, de lo contrario, la misma no habría tenido lugar. Este hecho nos lleva a concluir que este género debe ser definido dentro de un contexto de situación que es la celebración de la misa de Tedeum. Los textos analizados no pueden ser tomados como textos escindidos de dicho cuadro contextual puesto que, como señalamos con anterioridad, los mismos forman parte esencial de la celebración eucarística.

La motivación es, por tanto, la etapa que indica la razón por la cual se está llevando a cabo la celebración del Tedeum además de dar indicios del entorno socio-histórico en que esa celebración se está desarrollando, ya sea mediante 
la mención de las autoridades presentes o de algún acontecimiento relevante a nivel local.

Se trata de una etapa breve con contenidos que se repiten en diecisiete de los textos que componen el corpus. No presenta rasgos léxico gramaticales de gran relevancia que haya llamado nuestra atención. Sin embargo, pudimos observar que en esta etapa se pone de manifiesto a quién se está dirigiendo el emisor, o qué auditorio se tuvo en cuenta al momento de la redacción del texto además de indicar el marco institucional en el que el mensaje se emite así como el espíritu que inspira dicho mensaje.

\subsubsection{La fundamentación ideológica}

La función de la etapa identificada como fundamentación ideológica reviste, en primer lugar, un carácter informativo. Se informa a la audiencia acerca de la doctrina, el magisterio, las creencias y valores que darán sustento a la interpretación de las escrituras y de la realidad circundante. En esta etapa, se trae por medio de citas la voz autorizada de las sagradas escrituras, de los padres de la Iglesia, del magisterio católico y de quienes el locutor considere funcionales a su propósito de sustentar sus argumentos, así como de acercar la realidad distante expresada en el fragmento de la Biblia al aquí y el ahora.

En el análisis de los textos que nos ocupan, nos hemos encontrado con dos formatos de homilías:

En primer lugar, nos referiremos a aquellas que, siguiendo con lo que indican los cánones que se establecen para la predicación, se basan en un pasaje bíblico que pasa a ser parte del texto, puesto que el celebrante desarrolla una homilía exegética a partir de dicha lectura, es decir, hace una explicación, comenta e interpreta el fragmento bíblico para la edificación de los fieles (Spiazzi 1965). A este grupo pertenecen las homilías pronunciadas entre los años 1999 al 2004. En estos casos, se toma el texto bíblico como un relato ejemplar y su interpretación cumple una función persuasiva. La homilía que sigue a la lectura bíblica se podría definir como una reformulación explicativa 
que hace uso de un conjunto de estrategias argumentativas para alcanzar la persuasión de los destinatarios mediante el despliegue de una serie de analogías entre el relato bíblico y la situación actual del país, hecho que le permite desplazarse hacia el discurso político sin abandonar el plano religioso que es el que, en definitiva, posibilita la derivación de normas de acción comunes y al mismo tiempo diferentes según los grupos identificados discursivamente ( Arnoux y Blanco 2002)

Como ya dijimos, la interpretación de los pasajes bíblicos por parte del locutor es utilizada como medio para persuadir, ganar voluntades y convencer antes de pasar a la etapa siguiente de interpelación, que es donde se completa el ciclo motivar-explicar-persuadir-interpelar. Vemos en los siguientes fragmentos cómo el locutor, partiendo del pasaje ejemplar, establece una relación con la realidad:

Como en la Jerusalén de entonces, cuando Jesús atravesaba la ciudad y aquel hombre llamado Zaqueo no lograba verlo entre tanta muchedumbre, algo nos impide ver y sentir su presencia. En la escena evangélica se nos da la clave en términos de altura y de abajamiento. De altura, porque Zaqueo se deja ganar el corazón por el deseo de ver a Jesús y, como era pequeño de estatura, se adelanta y trepa a un sicómoro. Ningún talento, ninguna riqueza puede reemplazar una chatura moral o en todo caso, si el problema no es moral- no hay salida para una mirada baja, sin esperanza, resignada a sus límites, carente de creatividad.(H2002; 27-34)

La parábola del Buen Samaritano nos muestra con qué iniciativas se puede rehacer una comunidad a partir de hombres y mujeres que sienten y obran como verdaderos socios (en el sentido antiguo de conciudadanos). Hombres y mujeres que hacen propia y acompañan la fragilidad de los demás, que no dejan que se erija una sociedad de exclusión, sino que se aproximan -se hacen prójimos- y levantan y rehabilitan al caído, para que el Bien sea Común. Al mismo tiempo la Parábola nos advierte sobre ciertas actitudes que sólo se miran a sí mismas y no se hacen cargo de las exigencias ineludibles de la realidad humana. $(\mathrm{H} 2003$; 35-42)

El segundo grupo queda conformado por aquellas homilías en las que no se hace referencia alguna al Evangelio sino que se toman temas en forma aleatoria respecto de los cuales el locutor emite juicios desde la postura de la institución que representa. A este grupo corresponden las homilías de los años 1976, 1979, 1980, 1987, 1993, 1996 y del 2005 al 2010. La función de esta 
etapa sigue siendo la misma pero la referencia ya no está dirigida exclusivamente a una lectura bíblica determinada que se utiliza como apertura de la prédica, sino que se van trayendo a lo largo del texto voces autorizadas que aportan a la última finalidad de acercar al auditorio a la comprensión de la doctrina de la Iglesia para ponerla en práctica.

En los siguientes fragmentos, extraídos de homilías que no toman como punto de partida la lectura del Evangelio, el locutor hace constante referencia a fragmentos de la fuente máxima de conocimiento doctrinal, La Biblia, para sustentar su prédica:

En el Evangelio proclamado hoy, Jesús nos advierte precisamente que todo el que peca es esclavo del pecado (cnf. Jn. 8,34). Sin dimensión ética no hay libertad. La experiencia nos enseña que la libertad se arraiga en un pueblo, cuando busca la prosperidad por el camino de la justicia y la fraternidad; cuando las oportunidades de calidad de vida son ofrecida $s$ a todos, como una obligación de la sociedad y no como un privilegio de pocos. (H 1993; I 59-65)

Por eso, en la noble tarea de legislar es preciso tener presente que no puede hacer Patria sin atender a la ley del Señor. Nos dice Isaías que la Nación que no se someta a Dios será arruinada (Is. 60,12).( H 1993;I 76-78)

En efecto, en la primera de ellas estaban inscriptos los primeros tres mandamientos: amar a Dios sobre todas las cosas, no tomar su santo nombre en vano, santificar las fiestas. En la segunda de ellas, los demás: no matar, no fornicar, no robar, no mentir, etc. Como gozne o bisagra, el mandamiento cuarto: "honrarás a tu padre y a tu madre". jJustamente, el que funda el amor a la patria, la tierra o herencia de los padres! $)^{23}$. (H 2007;। 154-161)

San Pablo en su primera carta a Timoteo enseñaba el valor de la oración en común cuando afirmaba: "Ante todo te recomiendo que se hagan peticiones, oraciones, súplicas y acciones de gracias por todos los hombres, por los soberanos y por todas las autoridades para que podamos disfrutar de paz y de tranquilidad" (1Tim. 2, 1-2) (H 2009;। 31-34)

La Biblia, libro santo respetado por toda la humanidad, integra en su relato histórico el devenir de un pueblo elegido entre todas las naciones de la tierra. Narra su relación con Dios, sus horas de gloria y sus horas de vergüenza. Los momentos de mayor exaltación nacional de este pueblo coinciden con el más exuberante entusiasmo religioso. Así lo expresan los cánticos de Moisés, de

\footnotetext{
${ }^{23} 23$ Cfr. Catecismo de la Iglesia Católica, ns. 2197-2199
} 
Debora y de David. Por el contrario, la depresión nacional del pueblo va acompañada de un acudimiento al Dios salvador, único que puede salvarlos. Este tema aparece persistente, casi obsesivo, en los grandes profetas. Solo Dios, Él solo, sólo Él, nadie fuera del Él, nadie más que Él, Él basta. "Él rompe los arcos, quiebra las lanzas, quema los escudos; es superior a todos los pueblos poderosos, más alto que la tierra". (Salmo 46) (H 1980; I 33-42)

Luego se continúa con la interpretación del pasaje escogido. Así vemos que en todos los casos la interpretación se orienta a lo que el hombre "debe ser" y se deja claramente explícita la colaboración de la Iglesia en la búsqueda del Bien Común. Como ya dijimos, un aspecto relevante del discurso religioso, que se observa en particular en esta etapa, es la reiteración de expresiones deónticas, que se manifiestan mediante el uso de perífrasis verbales del tipo "hay que", "ha de", "tener que", entre otras, que refieren tanto a la obligación como a la necesidad (Gómez Torrego, 1997). Con dichas expresiones, se deja en claro la conducta que se deberá seguir de acuerdo a los preceptos emanados del pasaje del evangelio o de las fuentes de doctrina escogidas por el locutor.

Estas expresiones deónticas están presentes en todas las homilías pero por razones de espacio transcribimos solo algunos fragmentos.

Debemos, por tanto, cultivar un sano amor a la patria. A ello estimula la Iglesia a sus hijos. Ella, al buscar la salvación, no sólo comunica la vida divina al hombre, sino también difunde la luz evangélica a los problemas de la sociedad civil y trata de proteger y elevar la dignidad y los valores morales de la persona humana. Por eso mismo consolida y da firmeza a la comunidad política donde la Iglesia vive; al predicar la verdad evangélica e iluminar, con su doctrina y el testimonio de sus buenos hijos, los diversos sectores de la actividad humana, la Iglesia anima el estilo de vida y busca el verdadero bien de la comunidad política. (H 1976; 37-44)

Remunerados todos los sectores que interviene en la producción, ha de reconocerse también a los trabajadores una parte de los beneficios para lo cual ha de tenerse en cuenta no sólo la suficiencia del salario, sino también la condición de la empresa, como así también el bien común, tanto nacional como internacional. La primacía del servicio sobre el lucro, ya que no puede justificarse este ultimo si no corresponde a un verdadero servicio. La primacía por último de las verdaderas y reales necesidades del hombre frente a una desmedida oferta de bienes innecesarios que una sociedad consumista ofrece. (H 1979;। 34-41)

Esto no dice que aquel deseo de libertad que fue la mística de Mayo y debe ser nuestro futuro, no se refiera exclusivamente a eventuales presiones extranjeras, sino también a las falsas opciones que puedan aparecer en la misma sociedad nacional e impliquen violencia, injusticia o desprecio por los 
derechos de alguno. Solamente con respeto, justicia y amor por los demás se perdura como Nación libre. (H 1993;l 47-51)

Además de las expresiones deónticas, esta etapa se caracteriza por su profusión de afirmaciones categóricas en las que se definen conceptos básicos como Patria o Nación:

Patria es a la vez lo hecho: historia forjada lentamente; el idioma que unifica y la sangre nueva que congrega distintas etnias y culturas. Es pasado que se hereda se transmite; pero también es futuro que se aborda en comunidad. $(\mathrm{H}$ 1993; | 21-23)

Patria es decir padres, país, tradiciones, cultura, paisaje, territorio, sentimientos que podemos calificar de naturales, tanto que frente a algún traidor a esas realidades o a quien reniega de ellas decimos que es un mal nacido. (LC. 23,27-31).(H 1996; | 73-77)

Una Patria que no es sólo un territorio geográfico o una mera suma de hechos históricos, sino que implica "fundamentalmente la comunidad de hombres; congregados para diversos aspectos, pero sobre todo por el vínculo de una misma cultura. Reunidos así por una idéntica concepción del hombre y del mundo y por una sola escala de valores, que se traducen en actitudes, costumbres e instituciones comunes" (H1987; I 73-77)

"Una Nación es fundamentalmente la comunidad de hombres convocados por diversos aspectos, pero, sobre todo, por el vínculo de la misma cultura" (1). Realidad "de orden principalmente espiritual: que impulsa a los hombres, iluminados por la verdad, a comunicarse entre sí los más diversos conocimientos; a defender sus derechos y cumplir sus deberes; a desear los bienes del espíritu; a disfrutar en común del justo placer de la belleza en todas sus manifestaciones; a sentirse inclinados continuamente a compartir con los demás lo mejor de sí mismos; a asimilar con afán, en provecho propio, los bienes espirituales del prójimo."(cfr. Juan XXIII, Pacem in terris, n.36)

(H 2005; 8-15)

Pudimos observar también en el segundo fragmento del año 1996, la presencia de juicios de valor emitidos hacia quienes no cumplen o reniegan de los preceptos planteados o las realidades mientras que en el fragmento tomado de la homilía de 2005 la definición, tomada de una carta encíclica del papa Juan XXIII, está claramente sesgada según los preceptos religiosos y apuntan a lo que es la función global del texto: persuadir. En esta instancia se va preparando el camino hacia la exhortación expresada en la etapa de conclusión. 
También en esta etapa se presentan definiciones de Tedeum así como de conceptos que surgen en la prédica:

\begin{abstract}
¿Qué expresa el Te Deum? ¿Por qué es tan significativo este himno? ¿Cuál es su valor?

Expresa la actitud más noble y bella que el hombre puede tener ante Dios, que la criatura puede manifestar a su Creador, como se esclarece en su título más antiguo y sus primeras palabras: iTe Deum laudamus! iA Ti, oh Dios, te alabamos! (H 2007; I 70-74)
\end{abstract}

En este sentido, el Catecismo de la Iglesia Católica nos dice que "la oración de alabanza, totalmente desinteresada, se dirige a Dios; canta para Él y le da gloria no sólo por lo que ha hecho sino porque Él es"(13).(H 2007;l 110-113)

El servicio es la inclinación ante la necesidad del otro, a quien -al inclinarmedescubro, en su necesidad, como mi hermano. Es el rechazo de la indiferencia y del egoísmo utilitario. Es hacer por los otros y para los otros. (...) Servicio, palabra grabada a fuego en lo hondo del corazón de nuestro pueblo. $(\mathrm{H} 2001$; I 30-35)

La Paz, para decirlo con palabras de Juan XXIII tomadas de la maravillosa encíclica "Pacem in Terris", será una palabra vacía si no está fundada en el orden moral y por tanto ha de estar cimentada sobre la verdad, construida con las normas de justicia, vivificada e integrada por la caridad y realizada, en fin, con la libertad.(H 1979; I 110-113)

Dentro del grupo de homilías que no toman como punto de partida un pasaje del evangelio, el locutor suele recurrir a las enseñanzas de "máximos doctores", en las que también predominan las afirmaciones categóricas, con el mismo propósito de sumar voluntades, persuadir e indicar el camino a seguir.

La teología católica incluye el patriotismo, el amor a la Patria, entre las manifestaciones de la virtud de piedad, lo que lleva a Santo Tomás de Aquino, el máximo doctor de la Iglesia, a afirmar: "después de Dios, son también principios de nuestro ser y gobierno los padres, que de ellos hemos nacido; y la Patria puesto que en ella nos hemos criado. Por tanto, después de Dios, a los padres y a la Patria es quienes más debemos". (H1996; 68-72)

Tomás de Aquino enseña que la violencia del poderoso y la falsa prudencia del sabio corrompen la justicia. (H 1993; 71-72)

Por eso también San Agustín, en inmortales palabras, expresó al comienzo de sus Confesiones: "A pesar de todo, el hombre, pequeña parte de tu creación, quiere alabarte. Tú mismo le incitas a ello, haciendo que encuentre sus delicias 
en tu alabanza, porque nos has hecho joh Señor! para Ti y nuestro corazón está inquieto mientras no descansa en Ti"(14). (H 2007; I 110-113)

Por otra parte, cuando no se alude a una lectura bíblica también suelen tomarse citas breves de la doctrina de la Iglesia donde se pone de manifiesto el sistema de creencias de dicha institución. En los siguientes fragmentos, tomados de las homilías de los años 1976, 1979 y 1993, se recurre a la voz autorizada de los Papas expresada en los documentos fundamentales de la Iglesia como las encíclicas o en mensajes a comunidades particulares con motivo de viajes apostólicos.

Pío XII se lamentaba que algunos en estos tiempos, temen mostrarse particularmente amantes de su patria y agregaba que este disminuido amor a la patria, a esta gran familia que Dios nos ha dado, es una señal de la actual desorientación de los espíritus (Cfr. AAS. 958, pág. 219) (H 1976; 32-35)

Resuenan todavía hoy aquellas palabras de Pío XI en la "Quadragessimo Agno": "No es justo que lo que es resultado de la eficaz colaboración del trabajo y el capital, es decir, el beneficio, se lo arrogue una sola de las partes". (H 1979 ; 32-34

Nos recordaba el Papa cuando estuvo en Tucumán, que la cultura anterior a la independencia , marcada por principios cristianos y por sentimientos caros a nuestra sociedad, dio lugar a un estilo de vida inspirado en ideales de justicia, fraternidad y amor (cnf. Tucum.5; Mensajes-Paulinas 1987) (H 1993; 40-43)

Asimismo, en los ejemplos que detallamos a continuación se manifiesta cómo, en esta etapa de explicación, se recurre a los documentos de la Iglesia para establecer paralelos con hechos de la historia que se traen a colación, como en este caso, para venerar a alguna figura local con la intención de destacar valores comunes a todos.

El servicio de Facundo de Zuviría. A este ilustre salteño le correspondió presidir el Congreso Constituyente de 1.853 que consagró nuestra Constitución Nacional dando origen al estado organizado que consolidó el crecimiento y la evolución de la Nación. Su figura invita a recrear nuestra fidelidad a la ley y a las instituciones de la patria. Es bueno recordarlo en este año del vigésimo quinto aniversario del regreso a la democracia en la Argentina, convencidos que, como nos enseña la lglesia, " una auténtica democracia no es sólo el resultado de un respeto formal de las reglas, sino que es el fruto de la aceptación convencida de los valores que inspiran los procedimientos democráticos: la dignidad de toda persona humana, el respeto de los derechos del hombre, la asunción del bien común como fin y criterio regulador de la vida 
política. Si no existe un consenso general sobre estos valores, se pierde el significado de la democracia y se compromete su estabilidad" (1 COMPENDIO DE DOCTRINA SOCIAL DE LA IGLESIA , N ${ }^{\circ}$ 407.) (H 2008;। 19-30)

En la homilía del año 2008 en la ciudad de Salta, se destaca la figura local de Facundo Zuviría así como en la homilía del 2005, en Santiago del Estero, el orador recurre a un autor argentino como punto de partida para su reflexión:

Escribía Eduardo Mallea: "Haberse originado es originarse constantemente, nacer es seguir naciendo, y si no sabemos cómo y para qué llevamos en nosotros tan constantes nacimientos, esta ignorancia adquirirá, bajo el aspecto de una vida que se perpetua, el valor de una muerte que se repite"24. O sea, recordar es necesario para seguir caminando, seguir naciendo en la vocación original de ser nación, en el esfuerzo cotidiano de cada ciudadano, en el insustituible compromiso de poner lo mejor de cada uno al servicio del bien común, con el sacrificio de todos, especialmente de quienes más saben, más tienen y más pueden. Como creyentes, agradeciendo a Dios la sabiduría y la fortaleza para esta aventura ciudadana.( $\mathrm{H}$ 2005; I 25-34

También se toman, como voces autorizadas, los documentos emitidos por la Conferencia Episcopal Argentina en la que se pone de manifiesto la postura de los obispos como voz oficial de la Iglesia en nuestro país:

Los obispos argentinos queremos situarnos en la línea de Aparecida que nos llama a ser discípulos y misioneros de Jesucristo en este tiempo de la historia. Somos conscientes de que el mandato de la caridad que nuestro Señor nos manda vivir, alcanza y abraza a todas las dimensiones de la existencia, a todas las personas, a todos los ambientes y a todos los pueblos y nuestra Nación Argentina no escapa a este mandato. ${ }^{25}$ (H 2009; I 50-54)

Como todo comienzo, fue modesto pero impredecible, ya que fue el inicio de un pueblo que sería la Nación Argentina. "Una Nación es fundamentalmente la comunidad de hombres convocados por diversos aspectos, pero, sobre todo, por el vínculo de la misma cultura" ${ }^{26}$ (H 2005; 11-13)

Se desprende del análisis realizado, que esta etapa cumple la función de informar acerca de fuentes de conocimiento y doctrina y persuadir por medio de

24 (3) Historia de una pasión argentina, Bs. As., Sudamericana, 1961, p. 21

${ }^{25}$ Cita presente en el texto original correspondiente a: Hacia el Bicentenario en justicia y solidaridad. CEA 1996 Asamblea Plenaria de Obispos.

${ }^{26}$ Cita presente en el texto original correspondiente a: CEA, Iglesia y Comunidad Nacional, n. 77 
la elección tanto de temas y voces como del posicionamiento desde donde se emite el discurso. Estos hechos, así como la elección de determinado léxico y patrones gramaticales hacen que esta etapa actúe como una suerte de bastión o fundamento ideológico sobre el cual se construirán las etapas que le siguen. En esta etapa, se sientan las bases que servirán de sustento al momento de evaluar tanto positiva como negativamente, hechos, personas o estado de cosas así como para interpelar y llamar a la acción.

\subsubsection{La evaluación}

Una vez analizadas las etapas de motivación y de fundamentación ideológica, pudimos identificar segmentos de carácter marcadamente evaluativo respecto de actores sociales (el gobierno, el pueblo, la actualidad o de la historia argentina), razón por la cual denominamos a esta etapa de evaluación. La misma se manifiesta de diversas maneras en los textos, según la postura tomada por el locutor y el contexto de situación.

Hemos observado en las homilías correspondientes al período del gobierno de facto (1976-1983) que la evaluación se reduce a unas pocas líneas donde el locutor, mediante el uso de nominalizaciones, transforma procesos y cualidades en cosas, con el propósito de no hacer mención directa de los participantes de los procesos o portadores de las cualidades referidas (Martin y Rose, 2003: 106,107). La motivación funcional del uso de la nominalización tiene dos ventajas textuales: por un lado al nominalizar las relaciones lógicas y las acciones, podemos organizar nuestro texto no en términos relativos a nosotros mismos sino en términos de ideas, razones, causas etc. Por otro lado, la nominalización nos permite acumular más contenido léxico por oración. Por lo tanto, al nominalizar verbos y otras categorías de palabras, se incrementa la densidad de contenido del texto. Además, la nominalización aporta cierto tono de prestigio y seriedad al texto que en definitiva lo hace más reflexivo y le da un tono de mayor autoridad. (Eggins 2004: 94) ${ }^{27}$ Los fragmentos que reproducimos a continuación ilustran este hecho:

\footnotetext{
${ }^{27}$ Mi traducción
} 
Pío XII se lamentaba que algunos en estos tiempos, temen mostrarse particularmente amantes de su patria y agregaba que este disminuido amor a la patria, a esta gran familia que Dios nos ha dado, es una señal de la actual desorientación de los espíritus (Cfr. AAS. 958, pág. 219) (H 1976; I 32-35)

Este mismo magisterio que ha rechazado sin ambigüedades y seguirá rechazando siempre al marxismo materialista y ateo realizador de una dialéctica de violencia, negador al mismo tiempo de la libertad individual y de toda trascendencia del hombre. (H 1979; 71-73)

Te pedimos perdón por nuestras luchas entre hermanos, por la larga lista de reyertas fratricidas. Te pedimos perdón por nuestros períodos negros y rojos, por los accesos de ferocidad que periódicamente nos atacan y entenebrecen. (H 1980; | 82-84)

A primera vista, es difícil identificar estos fragmentos como evaluativos, de hecho fueron identificados en un primer análisis con etapas de fundamentación ideológica pero, leídas con detenimiento pudimos observar que se trata de fragmentos evaluativos en los que se oculta en forma deliberada a quienes se evalúa. Se habla en los tres fragmentos de cualidades negativas de los hombres que no aman a la patria y cuyos espíritus están desorientados, aquellos que optan por el marxismo materialista que han tomado la violencia como camino y que niegan la libertad individual y la trascendencia del hombre. Asimismo, en el tercer fragmento, se está nominalizando a los hermanos que luchan entre sí y quienes tienen accesos de ferocidad y que atacan y entenebrecen. Vale decir, que se corre la evaluación hacia un campo más abstracto: en vez de hablar de personas se habla de figuras abstractas como el disminuido amor a la patria, el marxismo materialista o las reyertas fratricidas.

Este recurso de ocultamiento de los agentes también se sigue utilizando en las primeras homilías de democracia en las que paulatinamente comienzan a introducirse los participantes o actores sociales evaluados.

Nuestra historia reciente de confusión, violencia $\boldsymbol{y}$ desencuentro ha marcado a nuestra Patria con un gran dolor y sufrimiento, que aún cuesta superar. (H1987; I 57-58)

Todos sabemos en la hora actual el país tiene muchos problemas que resolver. Quizás no recordamos que ello no sucederá sin el esfuerzo de todos, sin 
egoísmos ni cerrazones mentales. No es con agravios como se resuelven los problemas, sino con apertura de mente y corazón. ( H 1993; I 62-65)

En el año 1987, el locutor se refiere a la historia reciente de la dictadura (19761983), la persecución, la lucha armada y la guerra de Malvinas. Si bien atribuye la confusión, violencia y desencuentro a la historia así como el dolor y sufrimiento a la Patria, en realidad son las personas las que se confunden, ejercen la violencia y no generan el encuentro así como las que padecen el dolor y, como consecuencia, sufren. Asimismo, son las personas, que no se mencionan, las que no pueden superar dicho estado de padecimiento.

En las homilías del año 1993 en adelante observamos cómo esta etapa de evaluación va cobrando fuerza al mismo tiempo que el actor evaluado comienza a ser mencionado en forma explícita:

La religión despierta y garantiza en el ciudadano la vocación patriótica y a la vez exige del funcionario un ejercicio estrictamente ético al servicio de la comunidad; y de los ciudadanos, el cumplimiento de toda la normativa que haya tenido legítimo origen y esté ordenada al bien común: porque toda ley justa trasciende lo legal, para obligar moralmente. (H 1993;l 136-140)

Nadie ignora la influencia y características de quien ha sido denominado "cuarto poder": el periodismo, digamos mejor, desde hace unos años, los Medios de Comunicación Masiva o Social. Ellos también debieran hacer su examen de conciencia tanto más porque es indiscutible su influencia. ¿La verdad, la honestidad el respeto, la decencia que evita tanto lo soez como la mentira y la calumnia, no son exigencias de la función que ha abrazado el que se siente o se cree inclinado a ser transmisor de la palabra escrita $u$ oral? $(H$ 1996; I 53-9)

Mientras que en el año 1993 se explicita a quién se va a evaluar mediante la inclusión de subtítulos en el texto escrito- noble tarea del legislador y los derechos de los ciudadanos-, en el año 1996, el locutor hace un llamado a un examen de conciencia y enumera a quienes, a su entender, deberían hacerlo: partidos políticos, empresarios y, en el fragmento reproducido, el periodismo. 
Desde el año 1999, la etapa de evaluación se va tornando más relevante llegando en el año 2004 a ocupar el 56 \% de la totalidad del texto (ver cuadro 5.2 en Conclusiones) Con la intención de modificar un estado de cosas los obispos, como locutores, se posicionan polémicamente con respecto a un "otro", a quien adjudican la identidad de adversario explícito o implícito y, al mismo tiempo, se alinean solidariamente con el pueblo que padece.

Esta etapa se caracteriza también por el empleo reiterado de procedimientos como la negación o el uso de conectores de concesión. Se expresa tanto en forma de denuncia de la conducta de quienes tienen acceso al poder o ejercen el poder político como de elogio al pueblo fiel a los preceptos de la Iglesia, pero que padece la injusticia y el maltrato de quienes los gobiernan.

$\mathrm{Si}$ bien encontramos las primeras manifestaciones de esta evaluación contrapuesta en la homilía del año 1999, es en aquella del año 2001 que observamos claramente cómo el locutor imprime un hondo dramatismo a su discurso mediante la repetición de frases como trabajo que y ubicando a su propia audiencia en su discurso como aquellos, los que o quienes. Vale decir, utiliza a su audiencia como blanco de acusaciones pero como si fueran los otros. El mismo locutor, en la última frase los que creen que se habla para otros indirectamente deja claro que si bien está refiriéndose a ellos en tercera persona no son más que ellos, su audiencia, el blanco de su denuncia.

Se nos invita a beber del cáliz del trabajo duro y solidario que, desde el principio, conoció el hombre de nuestra tierra. Trabajo que mestizó, a pesar de muchos desencuentros, a aborígenes y españoles. Trabajo que costó sangre para la independencia, que forjó la admiración del mundo en la dedicación de educadores, investigadores y científicos. Trabajo que despertó la conciencia social de millones de postergados, como avanzada en el continente, y que también probaron y prueban nuestras artes y letras cuando cantan nuestra a veces tímida alegría de ser argentinos. El cáliz del trabajo solidario en el servicio es la respuesta más genuina a la incertidumbre de un país lleno de potencialidades que no se realizan o se postergan una $y$ otra vez, indefinidamente, deteniendo su derrotero de grandeza. Es la respuesta a la incertidumbre de un país dañado por los privilegios, por los que utilizan el poder en su provecho a cuenta de la legitimidad representativa, por quienes exigen sacrificios incalculables, escondidos en sus burbujas de abundancia, mientras evaden su responsabilidad social y lavan las riquezas que el esfuerzo de todos producen; por los que dicen escuchar y no escuchan, por los que 
aplauden ritualmente sin hacerse eco, por los que creen que se habla para otros. $\left(\mathrm{H} 2001 ;\right.$ I 103-118) ${ }^{28}$

Vemos en los siguientes casos la evaluación negativa que se hace explícitamente de los gobernantes. Aquí el locutor toma distancia utilizando afirmaciones del tipo el legislador jamás debería, para hablar del "deber ser" del funcionario y estipular con un tono de indiscutida autoridad cuándo su tarea se dignifica o envilece.

...Aunque se acceda a la legislatura por medio de los distintos grupos políticos que tienen su particular orientación, el legislador jamás debería anteponer los intereses partidarios al bien común.

Su tarea se dignifica con la constante preocupación por el bien del hombre y el respeto a la igual dignidad de cada uno; se envilece, en cambio, con la parcialidad o la afrenta; con el uso de argucias formales para evitar el discurso serio de los problemas que aquejan a la Republica; y con la visión unilateral de la realidad. (H 1993; $79-87$ )

Tomamos la homilía del año 2004 para ilustrar la etapa de evaluación ya que al ser la más polémica de las que componen el corpus, se puede detectar con mucha más claridad; además vemos que gran parte del texto corresponde a esta etapa. En ella, el celebrante (Bergoglio) toma una postura sumamente crítica respecto del gobierno que, a su vez, lo había acusado de haber colaborado con la dictadura militar que tuvo lugar entre los años 1976 y $1983 .^{29}$ Teniendo en cuenta este contexto de situación, notamos una fuerte toma de posición con la elección de la primera persona (resaltado en el texto) en la que se manifiesta claramente la postura del emisor frente a la interpretación del pasaje del Evangelio y de los acontecimientos, así como del juicio emitido. De todas maneras, si bien esta posición se atenúa mediante la utilización de la expresión moralizadora me parece en la cláusula siguiente se vuelven a realizar afirmaciones categóricas enjuiciatorias. La postura, en este caso, es

\footnotetext{
${ }^{28}$ El subrayado es del autor. El resaltado es mío.

29 El periodista Horacio Verbitsky publica en el año 2005 El silencio en el que investiga la complicidad de la Iglesia Católica argentina con la detención-desaparición de personas durante la última dictadura( 1976-1983). Aquí, revela cómo fue vendida a la Marina una isla que era propiedad de la Iglesia y que sirvió para ocultar flagrantes violaciones a los derechos humanos cometidas por las Fuerzas Armadas.
} 
claramente más cercana a la audiencia que aquella detectada en el resto de las homilías.

Jesús, fiel al estilo profético que acompañaba su paso entre los hombres, realiza gestos simbólicos, ¿qué significa este dejar Nazaret su "patria"? Me parece ver aquí una fuerte protesta contra los que se sienten tan incluidos que excluyen a los demás. Tan clarividentes se creen que se han vuelto ciegos, tan autosuficientes son en la administración de la ley que se han vuelto inicuos. $(\mathrm{H}$ 2004 ; $58-62$ )

En la homilía del 2004 citada, el celebrante continúa la crítica de quienes ostentan el poder en primera persona del plural. El contexto deja en claro a quién se refiere; sin embargo, la opción del "nosotros" en referencia al género humano, opera como mitigador. La denuncia sigue estando pero la tensión disminuye:

Somos prontos para la intolerancia. Nos hallamos estancados en nuestros discursos y contradiscursos, dispuestos a acusar a los otros, antes que a revisar lo propio. El miedo ciego es reivindicador y lleva a menudo a despreciar lo distinto, a no ver lo complementario; a ridiculizar y censurar al que piensa diferente, lo cual es una nueva forma de presionar y lograr poder. No reconocer las virtudes y grandezas de los otros, por ejemplo, reduciéndolos a lo vulgar, es una estrategia común de la mediocridad cultural de nuestros tiempos. $(\mathrm{H} 2004$; I 105-111)

Una confusa cultura mediática mediocrizada nos mantiene en la perplejidad del caos y de la anomia, de la permanente confrontación interna y de "internas", distraídos por la noticia espectacular para no ver nuestra incapacidad frente a los problemas cotidianos. Es el mundo de los falsos modelos y de los libretos. La opresión más sutil es entonces la opresión de la mentira y del ocultamiento,...eso sí; a base de mucha información, información opaca y, por tal, equívoca. (H 2004; 190-195)

Los fragmentos arriba reproducidos son prueba fehaciente de la postura polémica adoptada por el locutor frente al poder político en el primero, mientras que en el fragmento siguiente la denuncia va dirigida a la prensa sensacionalista.

Como ya se dijo en la descripción inicial de esta etapa, también es aquí donde se reivindican las virtudes del pueblo con una evaluación altamente positiva. El pasaje reproducido a continuación se inicia con un conector adversativo pero que anuncia un discurso contrastante respecto del que se venía emitiendo. Con 
un tono mas reivindicativo que el anterior, el locutor se excluye a sí mismo y en parte a su audiencia ubicando al pueblo como un "tercero".

Pero gracias a Dios, nuestro pueblo también conoce el camino humilde del machacar diario, el mismo de tantos años de vida oculta. El de apostar al bien y sostener sin estar seguros del resultado. Conoce el silencio dolorido y pacífico pero - a la vez- rebelde, de muchos años de desencuentros, promesas falsas, violencias e injusticias expoliadoras. Sin embargo, encara diariamente sus tareas, con mucho desgaste social y un tendal de marginaciones. Año a año renueva su confiada espera marchando peregrino a tantos lugares donde Dios y su Madre lo esperan para el diálogo reconfortante, fortalecedor $(\mathrm{H} 2004 ; 202-$ 208)

Esta última es la etapa que hace que el discurso religioso, marcado por la explicación e interpretación de las escrituras y por la apelación, se desplace hacia el discurso político con predominio de lo argumentativo y polémico, en el cual se imponen criterios religiosos para apelar a la acción política. Sin embargo, a partir del año 2005, los Tedeums, con la presencia del presidente de la Nación, comienzan a celebrarse en distintas catedrales de diócesis del interior del país, estratégicamente elegidas por las mismas autoridades nacionales y, nuevamente, la etapa de evaluación negativa de la clase dirigente desaparece de las homilías de estas celebraciones. Los textos correspondientes a este año en adelante sufren una transformación importante, ya que al quedar alineadas la postura del locutor con la de su audiencia, toma relevancia el elogio al accionar del gobierno. Se deja de lado el "deber ser", no se identifican ya las posiciones de nosotros/ustedes/ellos, tan marcadas hasta el 2004, enmarcando el discurso en un "nosotros alineados" e ignorando la postura antagónica que imponía la crítica. Se empieza a hacer mención de caudillos y acontecimientos históricos locales, siempre apuntando al elogio de la democracia y las bondades de un gobierno democrático.

Partiendo del análisis realizado hasta aquí, estamos en condiciones de afirmar que esta es la etapa más sensible a los cambios que ocurren en el nivel del contexto de situación, puesto que es la que más modificaciones sufre a lo largo de los 34 años en los que las homilías analizadas fueron pronunciadas. Su función consiste en poner en relieve los valores que la Iglesia considera dignos de elogio y, desde esa postura, evaluar actores y acontecimientos involucrados 
tanto en la celebración del Tedeum como en la vida institucional del país. De esta manera, vemos que el pueblo argentino, que encarna los valores propugnados por la doctrina cristiana, es siempre pasible de elogio y depositario de juicios de valor positivo mientras que la clase dirigente y los sectores que poseen alguna porción de poder son condenados, ya que su accionar no se condice con esa doctrina. Ahora bien, en las homilías pronunciadas durante el gobierno de facto (1976, 1979 y 1980) y aquellas correspondientes a las misas celebradas en el interior del país (2005 al 2010), la etapa de evaluación sufre modificaciones: en el primer grupo, como ya señalamos, esta etapa se manifiesta en muy pocas líneas en las que no hay una mención directa de los personajes evaluados puesto que el locutor nominaliza cualidades, conductas y procesos. Siguiendo a Martin y Rose, 2003, consideramos que esta estrategia permite al escritor generalizar acerca de procesos sociales y, por lo tanto, dificulta la comprensión del texto ya que se desdibuja quién es responsable de una acción o conducta determinada. En el segundo grupo, los fragmentos destinados a la evaluación son muy breves y se limitan al elogio hacia valores encarnados por el gobierno democrático, que ya no se lo evalúa como enfrentado con el pueblo como en el período anterior (1999-2004) sino que se agrupan pueblo y gobierno como destinatarios de valores de juicio positivo.

Respecto de su estructura, pudimos observar que, salvo en las homilías mencionadas como las más polémicas, la evaluación se hace presente esparcida dentro de los textos y no condensada en párrafos o en grandes bloques de texto.

\subsubsection{La conclusión}

Finalmente, nos referimos a la etapa que hemos denominado conclusión. Una vez realizadas la explicación y exposición doctrinal y, desde ese espacio, haber hecho las críticas pertinentes, el texto se cierra con una exhortación e invitación a la acción de los destinatarios en respuesta a los problemas concretos planteados siguiendo los preceptos expuestos. Ésta es una etapa en la que el locutor va exponiendo el propósito perseguido utilizando frecuentemente 
locuciones conjuntivas consecutivas (de forma que, de manera que, así que, de modo que, así pues, solo asi) o construcciones preposicionales del tipo para que, para ello (Gómez Torrego, 1997: 237). Se establece así una relación de causa efecto entre cláusulas explicitando, por un lado, las condiciones para cambiar el estado de cosas y, por el otro, la conducta a seguir para la obtención de los fines deseados. Esta etapa puede desplegarse parcialmente a lo largo del texto o solamente como conclusión de la totalidad del mismo. Ésto se puede ver en la homilía del año 1979 en la que la etapa aparece en forma parcial a medida que el texto se va desplegando, mientras que en la homilía del año 2003 cobra gran relevancia ocupando los dos últimos párrafos. (Ver anexo)

A continuación, reproducimos fragmentos en los que se resaltan en negrita las locuciones conjuntivas consecutivas y las construcciones preposicionales. Las mismas son muestra de las conclusiones parciales que se van entretejiendo dentro de la etapa de fundamentación ideológica poniendo en evidencia el carácter prescriptivo del texto en la homilía del año 1976.

Para que, de acuerdo con las enseñanzas del Concilio Vaticano II los cristianos cultivemos verdadera y eficazmente el amor a nuestra patria, resulta obvio que en la situación presente "es deber de todos contribuir a la recuperación y salvación de la Argentina" (Carta Pastoral del Episcopado Argentino del 16-V786). Para ello nuestro Episcopado en su último documento nos invita a una profunda conversión de los espíritus y corazones que, por una parte, se esfuerce en hacer respetar siempre los derechos humanos $y$ hacer desaparecer la violencia fratricida, y por otra, haga del bien común el criterio rector de las conciencias de las autoridades y ciudadanos. Sólo así podrán los diversos sectores del país asumir, en la proporción debida a sus posibilidades, la necesaria cuota de austeridad y abnegación que hemos de soportar para superar la delicada situación actual, de modo que el sacrificio pedido no signifique para algunos la renuncia de no sólo un bien superfluo, mientras que para otros lo sea de la satisfacción de una necesidad impostergable. (H 1976;1 53-65)

Por su parte, en la homilía del año 1979 esta misma etapa de conclusión se presenta como una expresión de deseo también encabezada por las construcciones preposicionales con para o para que y se invita a la plegaria para alcanzar la paz. 
Al rememorar la revolución de mayo, esa página nunca suficientemente ponderada de nuestra historia, en este mundo cada vez más interdependiente, pidamos también que él ilumine con su luz la mente de los que gobiernan las naciones, para que junto al bienestar y prosperidad convenientes, procuren también a sus conciudadanos el don magnífico de la paz, que cristo finalmente encienda las voluntades de todos para estrechar los vínculos de la mutua caridad para fomentar la mutua comprensión. En fin, para perdonar sus agravios. Así, bajo su acción y amparo, todos los hombres se aúnen como hermanos y florezcan entre ellos y reine siempre la anhelada paz. (H1979; I 6067)

Mientras en las homilías mencionadas el acento está puesto en el "para qué" hemos notado que en otras, como las homilías de los años 2008 y 2009, el punto de partida de la conclusión es el "por qué" se debe obrar de determinada manera. Hemos resaltado las locuciones de causalidad por eso y por ello, muy recurrentes en todas las homilías analizadas que surgen del conocimiento de algo expresado en los siguientes fragmentos tanto por el verbo sabemos como creemos.

Trabajemos por continuar construyendo la Nación que queremos. "Sabemos que una Nación es una comunidad de personas que comparten muchos bienes, pero, sobre todo, una historia, una cultura y un destino común. Por ello debemos volver a la raíz del amor que teje la convivencia social, entendida como un llamado de Dios" (H 2008; I 83-86)

Creemos estar ante una oportunidad única. Podemos aprovecharla, privilegiando la construcción del bien común, o malgastarla con nuestros intereses egoístas y posturas intransigentes que nos fragmentan y dividen.

Por eso debe ser exigencia para todos nosotros: obispos, gobernantes y miembros de la comunidad con alguna responsabilidad pública el sentirnos responsables por el bien general(...) .( H 2009; I 89-94)

Asimismo, podemos apreciar que esta etapa se manifiesta también como una exhortación tanto en forma de invitación o advertencia, como así también de crítica, en las que predominan las afirmaciones categóricas y en algunos casos, el verbo "deber" que acentúa la idea de obligación así como las oraciones condicionales. En los fragmentos reproducidos a continuación, podemos observar cómo esta etapa refleja el tono con que el locutor emitió el resto del texto, ya sea de crítica en la homilía del año 2001, de prescripción en la del 2002 o de amenaza en el 2004: 
En este día de la Patria nuestro pueblo nos reclama y nos pide que no nos cansemos de servir, que sólo así ese nuevo vínculo social que anhelamos, será una realidad. Ya hemos probado hasta el hartazgo cómo se desgasta nuestra convivencia por el abuso opresor de algún sector sobre otro, con los internismos que dan la espalda a los grandes problemas, con equívocas lealtades, con los enfrentamientos sectoriales o ideológicos más o menos violentos. Estas dialécticas del enfrentamiento llevan a la disolución nacional, anulan el encuentro y la projimidad. El servicio nos invita a converger, a madurar, a crear -en definitiva- una nueva dinámica social: la de la comunión en las diferencias cuyo fruto es la serenidad en la justicia y la paz. Plural comunión de todos los talentos y todos los esfuerzos sin importar su origen. Comunión de todos los que se animan a mirar a los demás en su dignidad más profunda.

Ésta es la propuesta evangélica que hoy planteamos en la conmemoración de la fecha que es memoria viva de nuestras más hondas reservas morales como pueblo; propuesta que será, si la asumimos, el mejor homenaje a nuestros próceres y a nosotros mismos. (H 2001; | 169-182)

Vemos en esta homilía muy crítica cómo en la conclusión prevalecen las oraciones condicionales que, en definitiva, imponen una línea de pensamiento. La crítica está evidenciada en el texto como lo demuestra la utilización de expresiones como abuso opresor, internismos, dar la espalda, enfrentamientos sectoriales, violentos, etc. $Y$ como contrapartida, la evaluación positiva que sugieren los términos servicio, madurar, crear, comunión, justicia, paz, dignidad etc.

En la homilía del año 2002, se vuelve a la prescripción con expresiones como hay que o debemos y el uso del futuro para predecir lo que entonces sí ocurrirá. Hay una condicionalidad expresada a lo largo del párrafo.

La historia nos dice que muchos pueblos se levantaron de sus ruinas y abandonaron sus ruindades como Zaqueo. Hay que dar lugar al tiempo y a la constancia organizativa y creadora, apelar menos al reclamo estéril, a las ilusiones y promesas, y dedicarnos a la acción firme y perseverante. Por este camino florece la esperanza, esa esperanza que no defrauda porque es regalo de Dios al corazón de nuestro pueblo. Hoy, más que nunca, nos convoca la esperanza. Ella nos inspira y da fuerzas para levantarnos y dejarnos mirar por Dios, abajarnos en la humildad del servicio, y dar dándonos a nosotros mismos. Por momentos soñamos una convocatoria, la esperamos mágica $y$ encantadoramente. El camino es más sencillo: sólo debemos volver al Evangelio, dejarnos mirar como Zaqueo, escuchar el llamado a la tarea común, no disfrazar nuestros límites sino aceptar la alegría de compartir, antes que la inquietud del acaparar. $Y$ entonces sí que escucharemos, dirigida a nuestra Patria, la palabra del Señor: Hoy ha llegado la salvación a esta casa, porque el 
Hijo del Hombre vino a buscar y a salvar lo que estaba perdido (LC 19: 10) $(\mathrm{H}$ 2002; | 160-173)

La amenaza en la homilía de 2004 se manifiesta en el verbo debemos y por la frase final según la cual el solo hecho de no optar por lo propuesto desemboca indefectiblemente en tragedia.

La Palabra, como la historia, nos deja un código donde espejarnos. Pero, además, hay también espejismos. Hoy como siempre los argentinos debemos optar. No hacerlo es ya una opción, pero trágica. (H 2004; 244-246)

Por su parte, en la homilía del año 2000 esta misma etapa se manifiesta con un tono alentador, como si fuera un slogan político, con la expresión Podemos, sí podemos para luego pasar a la denuncia de quienes defraudan a los ancianos y entristecen a los jóvenes. La función de esta etapa de expresar el deseo de que ocurra un cambio y se imponga cierto orden de ideas se manifiesta en este y en varios textos con frases encabezadas por el término ojalá seguido del presente del subjuntivo para finalmente cerrar con la expresión de deseo de un cambio en tiempo futuro.

Podemos, sí podemos, no tenemos que dudar, podemos devolver una joven Argentina a nuestros mayores, a nuestros ancianos: esos hombres y mujeres que hoy, con tanta frecuencia, llegan al ocaso de su vida y no pueden tener "júbilo" porque han sido defraudados y se encuentran al borde del escepticismo. Con ellos tenemos una deuda, no sólo de justicia sino también de supervivencia para nuestros jóvenes, pues ellos son rescoldo de memoria. Ojalá nos animemos a devolverles una esperanzada Argentina, como el joven devuelto a su madre, para que ellos animen con su sonrisa de esperanza la vida de los jóvenes hoy entristecidos. Y entonces veremos que el que creíamos muerto se levantará, como leímos en el Evangelio, y comenzará a hablar. Entonces comprenderemos que "la esperanza no defrauda" (Rom. 5:5). (H 2000; | 124-134)

Hemos observado que esta homilía del año 2000 se cierra con un mensaje esperanzado, el mismo espíritu que se transmite en la totalidad de la homilía que, si bien tiene secuencias de opinión negativa, éstas se equilibran con otras positivas. Esto es así debido a que el locutor, el mismo Bergoglio, y su audiencia, el gabinete del presidente De la Rúa, no están enfrentados como en 
las homilías pronunciadas en los años posteriores durante la gestión del presidente Kirchner.

En los pasajes reproducidos a continuación, vemos cómo ese deseo presente en la etapa de la conclusión se expresa también mediante el uso de cláusulas en presente del subjuntivo encabezadas por la partícula que.

Aquel Mayo histórico, lleno de vaivenes e intereses en juego, supo congregar a todo el pueblo virreinal a una decisión común, iniciadora de otra historia. Quizás necesitemos sentir que la Patria de todos es un nuevo Cabildo, una gran mesa de comunión donde, no ya la nostalgia desolada, sino el reconocimiento esperanzador, nos impulse a proclamar como los discípulos de Emaús: "¿Acaso no ardía nuestro corazón mientras nos hablaba en el camino y nos explicaba las Escrituras?" Que arda nuestro corazón en deseos de vivir y crecer en este hogar propio sea la petición que acompañe esta acción de gracias al Padre y el compromiso de cumplir con su Palabra; convenciéndonos una vez más que el todo es superior a la parte, el tiempo superior al espacio, la realidad es superior a la idea y la unidad es superior al conflicto. (H 1999; I 192201)

Que nuestra Madre, María Santísima de Luján, que se ha quedado con nosotros y nos acompaña por el camino de nuestra historia como signo de consuelo y de esperanza, escuche nuestra plegaria de caminantes, nos conforte y nos anime a seguir el ejemplo de Cristo, el que carga sobre sus hombros nuestra fragilidad. (H 2003; I 198-201 cierre)

Que María, madre del Verbo Eterno y Madre de Jesús de Nazaret nos ayude en este camino de construir nuestro destino de patria y de nación. $(\mathrm{H} .2009$; I 105-106)

El recurso gramatical de subjuntivo es utilizado también para expresar advertencia, como vemos en el siguiente fragmento de cierre de la homilía del año 1996:

Es un hecho ya advertido en la inmediata post-guerra, la globalización que algunos llaman "mundialización". El mundo se ha convertido en una "gran aldea". Que ese fenómeno no desarraigue de nuestro espíritu el sentido de pertenencia y amor de Patria, el auténtico patriotismo. Pero nosotros tampoco nos enredemos en lo que llamaría problemáticas o rencillas "domésticas" o peleas barriales o presentarnos como los únicos e impolutos salvadores, que son maneras de descuidar los verdaderos serios problemas de la Nación. (H 1996; 1 109-115)

Hemos observado en repetidas oportunidades el uso de las perífrasis verbales hemos de, tenemos que, hay que para expresar tanto obligación como 
necesidad, poniendo así en relieve un carácter prescriptivo. Si bien estas construcciones se manifiestan en otras etapas, en ésta se dan especialmente cuando su función consiste en cerrar un texto con las mismas características de modo que su función específica contribuye a reforzar la función global de la totalidad del texto.

Todos los días hemos de comenzar una nueva etapa, un nuevo punto de partida. No tenemos que esperar todo de los que nos gobiernan: esto sería infantil, sino más bien hemos de ser parte activa en la rehabilitación y el auxilio del país herido. (H 2003; I 156-158)

Para esto hay que tocar al doliente, al que todos creen muerto. Hay que darle valor: "Joven, te lo mando, levántate". Para esto, como Cristo, hay que atreverse a renunciar al poder que acapara y enceguece, y aceptar ejercer la autoridad que sirve y acompaña. (2000; I 101-104)

Dentro de esta misma etapa se recurre al imperativo en $1^{\underline{a}}$ persona del plural tanto para invitar a seguir una conducta determinada, como para evitarla:

No confiemos en los repetidos discursos y en los supuestos informes acerca de la realidad. Hagámonos cargo de la realidad que nos corresponde sin miedo al dolor o a la impotencia, porque allí está el Resucitado. (H2003;1 169172)

Roguemos a la Virgen de Luján, Patrona de la patria, para que la conduzca por los caminos del desarrollo, la justicia y la paz. (H 1996; I 109-118)

Pidamos a Dios en este día de alabanza con sinceridad de corazón que nos haga ciudadanos de esta tierra pero también ciudadanos del cielo, para que la fe, la esperanza y el amor contenidos en los Evangelios abra en nuestros corazones un camino y una luz nueva y esperanzadora que nos lleve a privilegiar la construcción del bien común de nuestra patria (7).

Esta herencia que es viva en el corazón del pueblo, me impulsa a pedirles a todos los argentinos tres compromisos, que los obispos miembros de la Conferencia Episcopal propusimos a todo el pueblo de la patria en el andar de estos años nuestros:

1. Trabajemos por continuar construyendo la Nación que queremos. (...)

2. Renovemos nuestro esfuerzo por consolidar el sistema democrático desde el respeto a la constitución y a las instituciones de la patria. (...)

3. Apostemos con audacia creativa y confianza renovada a la amistad social y al diálogo como camino para construir la comunidad nacional. (H 2008; I 79121)

En otros casos, la conclusión toma forma de oración a Dios como en la homilía del año 1980, en la cual el celebrante, asumiendo el rol de intermediario entre 
la audiencia y Dios, transforma su alocución en una plegaria que alterna el pedido de perdón y la acción de gracias.

Oh! Cristo que presides a hombres y pueblos, que al final de los tiempos habrás de juzgar a vivientes y muertos, que escrutas los corazones humanos y a quien nada pasa desapercibido pero que mientras dura el tiempo de la historia eres paciente y tolerante, haces brillar sol sobre buenos y malos recibe las gracias que el pueblo argentino a través de sus hijos más representativos te tributa por la mediación de tu madre, la muy clemente, piadosa y dulce Virgen María. (H 1980; I 112-117)

Lo mismo ocurre con la homilía del año 2010 encuadrada en la celebración del bicentenario de la Revolución de Mayo

En el bicentenario que comenzamos a celebrar nos ponemos una vez en tus manos María de Luján, para que nos alcances de tu Hijo Jesús la fortaleza y la sabiduría que nos encaminen decididamente hacia la Patria de hermanos que soñamos. Por eso te pedimos nos concedas Señor:

Humildad para poder servirte en los pobres.

Esperanza para superar las dificultades.

Paciencia para saber construir con generosidad y alegría.

Hambre y sed de justicia para trabajar por un mundo nuevo.

Misericordia para sabernos perdonados.

Un corazón puro para descubrirte en todos.

Ser artesanos de la paz en cada día de nuestra vida.

En una palabra, no avergonzarnos nunca de creer en Ti y vivir con coherencia

el Evangelio.

Jesucristo Señor de la historia, te necesitamos. Sé nuestro Pastor y guíanos siempre. Amén. (H 2010; I 133-147)

Podría interpretarse que este recurso de la plegaria es utilizado por el locutor para tomar distancia de lo que sería un discurso más comprometido y, por lo tanto, más terrenal o mundano y controvertido como el que se produce en las homilías más críticas.

En la homilía de 2005 que tiene un propósito de elogio hacia el gobierno por parte del celebrante, encontramos una conclusión más orientada a acentuar valores positivos ya mencionados en otras etapas: 
En este día tan especial para la Nación, ofrezcamos todos, sin excepción, nuestro compromiso sincero y concreto por seguir gestando una Nación libre y soberana, donde ninguno de sus hijos sea excluido; respetuosa del derecho y con la cordura del diálogo en la resolución de sus conflictos. Para ello los creyentes ponemos nuestra mirada en el Señor para decir:

Jesucristo, Señor de la historia, te necesitamos. (Y continúa con una plegaria) (H 2005; I 64-68)

Asimismo, en una homilía como la del año 1976, prescriptiva en casi su totalidad, cuyo locutor está alineado al gobierno de facto y, por lo tanto elude la crítica a actores sociales concretos, encontramos una conclusión en la que se expresa el deseo de que todos contribuyan a la tan ansiada recuperación nacional. Con esta frase se está haciendo referencia al proceso de reorganización nacional que fue como se designó a la dictadura militar que se había instaurado por medio de un golpe de estado dos meses antes. Con esta conclusión el celebrante cierra su alocución:

Que Dios, Nuestro Señor, nos conceda a todos los argentinos la gracia de amar eficazmente a nuestra patria, de modo que cada uno en su puesto y según sus posibilidades, contribuya de verdad a la tan ansiada recuperación nacional, en la paz, justicia y amor. Así sea. (H 1976; I 67-70)

Lo mismo ocurre en la homilía del año 1979 con similares características a la anterior, en la que no se sabe bien a quién se está convocando:

Sí, vamos a cantar un himno de acción de gracias, pero ello debe comprometernos a todos a reubicar al hombre y en nuestro caso al hombre que habita este bendito suelo, como sujeto, centro, fin y fundamento de toda actividad política, económica, social, cultural y aún religiosa. (H 1979; I 82-85)

Luego del análisis detallado de esta etapa, podríamos concluir que, desde el punto de vista formal, la misma puede manifestarse en bloque al final de los textos o en frases que van indicando el curso de acción a seguir a modo de conclusiones parciales que en definitiva terminan desembocando en una conclusión más totalizadora en el cierre. En cuanto a su función, esta etapa de conclusión sirve al propósito de poner de manifiesto la exhortación y el llamado a la acción siguiendo los principios expresados en la homilía. También pudimos observar que esta etapa continúa con el tono de elogio, de plegaria, de crítica o simplemente de exposición doctrinal de la totalidad de la homilía a la que pertenece, para poner fin y sintetizar tanto los conceptos como el espíritu 
presentes en el texto. Se caracteriza también por una profusión de términos y construcciones que indican lo que hay que hacer para vivir de acuerdo a los preceptos de la Iglesia.

Como se ha podido observar, nuestro análisis está orientado siempre a la acción lingüística mediante la cual el locutor o escritor intenta establecer una determinada relación comunicativa con el oyente o lector. Cada una de las etapas descritas, como ya señalamos, cumple una función comunicativa que colabora, por así decirlo, con la función global del texto. De este modo, nuestra clasificación se fundamenta en la identificación de clases de acciones que se llevan a cabo y para ello necesitamos observar rasgos vinculados con el contexto de situación. Longacre y Levinsohn, 1978 en Ciapuscio 1994) proponen dos parámetros primarios para distinguir tipos de textos; ellos son: +/encadenamiento cronológico y +/- orientación hacia el agente. Obedeciendo a estos parámetros, podríamos decir que la primera etapa de motivación está marcada negativamente con respecto a ambos parámetros puesto que al tratarse de un texto expositivo no hay una sucesión temporal de acontecimientos y tampoco se hace referencia a participantes más que los sujetos históricos protagonistas de los acontecimientos referidos. Las etapas de fundamentación ideológica y conclusión son ambas de claro corte expositivo/ conductual que incluye la exhortación y la apología, aspectos relevantes del discurso religioso. El discurso de ambas etapas está marcado positivamente con respecto a la referencia al agente y negativamente respecto del encadenamiento temporal. En cuanto a la etapa de evaluación, nos encontramos con una marcada referencia personal u orientación hacia los agentes mientras que el orden de las intervenciones podría invertirse sin que este hecho afecte la función que esta sección del texto cumple.

Ahora bien, siguiendo esta clasificación, los autores consideran los parámetros secundarios de +- proyección y +- tensión según se trate de textos en los que se contempla o anticipa una determinada acción (proyección) o si reflejan cierta polémica. Dentro de los fragmentos expositivos que se dan en la etapa de motivación, no hay proyección ni tensión; sin embargo, en la etapa de evaluación en la que se refleja un conflicto o polarización de concepciones 
frente a la vida y aspectos doctrinales, la tensión es alta. En cambio, la etapa de fundamentación ideológica donde la información se presenta como inapelable y de manera objetiva, carece de tensión aunque sí tiene proyección hacia agentes, al igual que la etapa de conclusión en la que prevalece la exhortación. Si bien algo aproximativa y global, esta clasificación nos pareció de utilidad para los fines de ordenamiento de las etapas de acuerdo al tipo textual al que obedecen.

\section{Estructuración de los textos}

De las etapas arriba mencionadas, todas - la motivación, fundamentación ideológica, evaluación y conclusión - fueron identificadas como obligatorias. Hay, sin embargo, dos textos en todo el corpus que hemos considerado incompletos puesto que no presentan alguna de estas etapas pero que de todos modos pueden encuadrarse dentro del género.

Hemos visto que todas las etapas presentes hacen su aporte desde sus funciones particulares a la función global del texto de persuadir e instar al cambio mediante la exposición de la doctrina y la evaluación de actores y sus conductas. Siguiendo los lineamientos de la LSF, la estructura de la homilía quedaría expresada de la siguiente manera:

\section{HOMILÍA DE TEDEUM}

\section{Motivación ^ Fundamentación ideológica ^ Evaluación ^ Conclusión}

Cuadro 4.1 : Estructura genérica de la Homilía de Tedeum.

A modo de resumen, reproducimos a continuación un cuadro en el que se detalla la función global del género homilía de Tedeum de 25 de mayo así como las funciones particulares de cada una de sus etapas constitutivas: 
HOMILÍAS DE TEDEUM DE 25 DE MAYO Exhortar y persuadir al destinatario a que lleve a cabo una acción y/o modifique su conducta de acuerdo a los preceptos emanados de la doctrina de la Iglesia utilizando estrategias del discurso político: la denuncia y/o el elogio de los actores sociales involucrados en el acto de enunciación.

\begin{tabular}{cll}
\hline ETAPAS & \multicolumn{1}{c}{ FUNCIÓN } \\
\hline 1. MOTIVACIÓN & $\begin{array}{l}\text { Ubicar el discurso en tiempo y espacio. } \\
\text { Dar a conocer a quién se dirige y las } \\
\text { razones por las que se pronuncia una } \\
\text { homilía así como el espíritu que la } \\
\text { inspira. }\end{array}$ \\
\hline 2. FUNDAMENTACIÓN IDEOLÓGICA & $\begin{array}{l}\text { Dar cuenta de la doctrina, el magisterio, } \\
\text { las creencias y valores que ofician de } \\
\text { sustento a la interpretación tanto de las } \\
\text { escrituras como de la realidad } \\
\text { circundante para luego evaluar hechos, } \\
\text { personas o estado de cosas. }\end{array}$ \\
\hline 3. EVALUACIÓN DE ACTORES & $\begin{array}{l}\text { Evaluar actores sociales involucrados en } \\
\text { la celebración del Tedeum así como en } \\
\text { la vida institucional del país según los } \\
\text { valores que la lglesia considera dignos } \\
\text { de elogio o condena. }\end{array}$ \\
\hline 4.CONCLUSIÓN & $\begin{array}{l}\text { Exhortar y llamar a la acción de los } \\
\text { destinatarios con respecto a los } \\
\text { problemas planteados en la etapa de } \\
\text { evaluación siguiendo los preceptos } \\
\text { doctrinales expuestos } \\
\text { fundamentación ideológica. }\end{array}$ \\
\hline
\end{tabular}

Cuadro 4.2 : Función global y funciones específicas de cada etapa constitutiva de la homilías de Tedeum. 


\subsection{La Valoración}

\subsubsection{Las voces incorporadas al discurso}

En el capítulo anterior, se mostró el resultado del análisis de los textos con el propósito de identificar las etapas constitutivas del género homilía de misas de Tedeum. El segundo abordaje apunta al estudio de la marca del emisor en la construcción discursiva de los textos, para lo cual fue necesario profundizar en el análisis del lenguaje evaluativo. Es de relevancia especial para esta investigación la noción de las tres metafunciones del lenguaje —ideacional, interpersonal, y textual- que operan de manera simultánea (Halliday y Matthiessen 2004). La evaluación corresponde a la metafunción interpersonal del lenguaje, vale decir, al plano de la interacción, en el cual se negocian las relaciones sociales y se expresan los sentimientos. Hemos visto que desde la perspectiva del contexto, los distintos tipos de campo, tenor y modo condicionan el significado ideacional, interpersonal y textual mientras que las selecciones de estos significados construyen diferentes tipos de contexto (Eggins y Martin, 2003).

De acuerdo a lo planteado por White, 2003, nos hemos detenido en la categoría de la "proclamación", que, a su vez, se subdivide en los recursos de "coincidencia", "pronunciamiento" y "respaldo". Veremos cómo con los valores de "coincidencia", los emisores representan sus proposiciones o propuestas como irrefutables puesto que coincidirían con los conocimientos o creencias de la mayoría. En su mayoría, estos enunciados se expresan en los textos por medio de afirmaciones categóricas, y tienen la función retórica de crear un acercamiento con los receptores (White, 2003:272). Entendemos como receptores a los feligreses que comparten con el locutor la fe en Dios y la Iglesia, no coincidente en su totalidad con la audiencia presente. Con el "pronunciamiento", los emisores se introducen directamente en el texto como la fuente responsable del enunciado. Estos recursos pueden tomar la forma de una intervención explícita del autor en el texto, ya sea mediante el uso de la primera persona del singular o alguna expresión con la cual se deja en claro 
que es su opinión o punto de vista. Tanto la "coincidencia" como el "pronunciamiento" son recursos de intravocalización. El "respaldo", en cambio, es un recurso de extra-vocalización que representa el apoyo de los emisores a la veracidad o la validez del enunciado atribuido. Dentro de esta categoría, si bien haremos una referencia a recursos de intravocalización, nuestro análisis se centrará más específicamente en el recurso de "respaldo".

Respecto del tenor, aspecto que nos ocupa en especial aquí, las elecciones de significado interpersonal en nuestro corpus incluyen la presencia de pronombres de primera persona del plural, cuando los locutores/ escritores se hacen responsables de lo que están produciendo. Por otro lado, los textos ponen en evidencia el deseo del emisor de exponer su postura avalada por la institución que representa mediante fragmentos de discurso referido construidos, en gran parte, por afirmaciones categóricas. Estas afirmaciones, presentes en todas las etapas constitutivas de los textos, son característica determinante del género homilético. También hemos notado la recurrencia de enunciados en los que la voz textual se ubica en una posición de apertura hacia otras voces y posturas alternativas marcadas como posibles 0 autorizadas. En su mayoría, el emisor pone de manifiesto el tipo de relación que él establece con enunciados anteriores dentro de la misma esfera, vale decir, con los hablantes que hayan adoptado anteriormente una postura respecto del tema tratado en el texto. Esta relación que establece el emisor actual con los anteriores es, en gran medida, de respaldo, puesto que se refiere explícitamente a esas voces como fuente, o simplemente, para avalar su discurso.

Para la presente investigación, se adoptaron, asimismo, los términos "polifonía" y "monofonía" de Barros 2003 [1994]:5-6). Con el primero, se caracteriza un tipo de texto en el que se dejan entrever muchas voces, en contraposición a los textos monofónicos, que esconden los diálogos que los constituyen. Según las estrategias discursivas utilizadas, se producen textos donde las voces se muestran o, por el contrario, se ocultan bajo la apariencia de una sola voz. Barros señala que los textos son siempre dialógicos porque resultan de la oposición de muchas voces sociales, pero que no obstante pueden producir 
efectos de polifonía cuando esas voces, o algunas de ellas se dejan escuchar, o de monofonía, cuando el diálogo esta enmascarado y solo se oye una sola voz. Ducrot (1986) desarrolla la teoría polifónica de la enunciación a partir del concepto bajtiniano de polifonía, que el teórico ruso elaborara a partir de los textos literarios. En esta teoría, Ducrot impugna el postulado de la unicidad del sujeto hablante, y lo reemplaza por las nociones de sujeto hablante (ser empírico) y locutor (ser del discurso). ${ }^{30}$

Los fragmentos reproducidos a continuación ponen en evidencia cómo el locutor recurre al discurso atribuido como fuente de autoridad para reafirmar los conceptos expresados por él. Este tipo de cita directa se manifiesta en el texto introducida o bien por un verbo neutro como decir o como cita directa sin verbo anunciador de la cita (verba dicendi) (Calsamiglia Blacafort y Tusón Vals, 1999).

En este sentido, el Catecismo de la Iglesia Católica nos dice que "la oración de alabanza, totalmente desinteresada, se dirige a Dios; canta para Él y le da gloria no sólo por lo que ha hecho sino porque Él es"(13). (H 2007; I 107-109)

Toda otra opción termina o bien del lado de los salteadores o bien del lado de los que pasan de largo, sin compadecerse del dolor del herido del camino. Y "la patria no ha de ser para nosotros -como decía un poeta nuestro- sino un dolor que se lleva en el costado".(H 2003; I 31-34)

En este día de la Patria, quiero detenerme en la enseñanza del Señor: "el que quiera ser grande que se haga servidor de Ustedes; y el que quiera ser el primero que se haga su esclavo: como el Hijo del Hombre, que no vino para ser servido sino para servir..."(Mt 20,26-28) (H 2001; I 24-27) (el subrayado es del autor)

Sin embargo, en otros pasajes hemos notado que el emisor rechaza las posturas alternativas que él mismo menciona. En el siguiente párrafo, se deja explícito qué postura se rechaza para finalmente traer la voz que se autoriza. Dentro de la cita directa la negación abre otra voz que es la que no se alinea

\footnotetext{
${ }^{30}$ A su vez, Ducrot (1986) propone distinguir, en el interior de la noción de locutor, entre el "locutor como tal", responsable de la enunciación, y considerado únicamente en virtud de esta propiedad, y el "locutor como ser del mundo", que tiene entre sus propiedades, la de ser el origen del enunciado. Esta distinción no se toma en cuenta en la presente investigación.
} 
con lo que el magisterio de la Iglesia sostiene, vale decir, que dentro de esa voz incorporada se activa otra por medio de la negación. Recordemos que la vertiente Sistémica considera que toda negación supone una afirmación previa que es la que se rechaza:

Sí, este mismo magisterio que ha rechazado sin ambigüedades $y$ seguirá rechazando siempre al marxismo materialista y ateo realizador de una dialéctica de violencia, negador al mismo tiempo de la libertad individual y de toda trascendencia del hombre, ha rechazado también sin ambigüedades a la ideología liberal, que cree exaltar la libertad individual sustrayéndola a toda limitación, estimulándola con la búsqueda exclusiva del interés y del poder, y por ello si siempre ha defendido el derecho natural de propiedad privada, aún de los medios de producción, frente a los ataques socializantes, no con menos énfasis ha afirmado que "la propiedad privada no constituye para nadie un derecho incondicional y absoluto, que no hay ninguna razón para reservarse en uso exclusivo lo que supera a la propia necesidad cuando a los demás les falta lo necesario". (H 1979; I 71-81)

La última frase es una cita directa pero, aunque no se revela la fuente, todo hace pensar que fue tomada de algún documento del episcopado.

En el fragmento siguiente, la voz textual trae la voz de los Sumos Pontífices que reconoce como válida y, por otro lado, desautoriza la voz que afirmaría que se pueden defender los propios derechos "pisoteando los de los demás", o la que propone "tender muros en vez de puentes".

El 25 de mayo de 1810 nuestro Pueblo decidió comenzar a ser un Pueblo independiente. Cada pueblo tiene el derecho a su propia tierra con su soberanía y su libertad. Esto lo han dicho siempre los papas a todos y para todos. No se pueden defender los propios y legítimos derechos pisoteando los de los demás. Por eso ante las discusiones y / o pretensiones por una misma tierra, los papas se han pronunciado a favor de que cada Estado goce de la misma libertad, soberanía y seguridad. Y esto se hace tendiendo puentes y no muros. (H 2006; 60-66)

En la homilía del año 1979, el celebrante, utiliza la voz históricamente autorizada del orador sagrado, Lacordaire, no como respaldo sino para contradecirla y, de este modo, reafirmar su postura. Este tipo de cita no es habitual en este género que, como ya se mencionó con anterioridad, está construido mayormente sobre voces que dan respaldo a los conceptos expuestos. 
Finalmente la verdadera paz debe ser realizada con libertad. Pero una libertad que no significa ni se define como "hacer lo que se quiere", sino como el "derecho y la obligación de hacer lo que se debe hacer". Una libertad, en fin, que no permita se escuchen aquellas frases del célebre Lacordaire, quien decía: "entre el pobre y el rico, entre el débil y el fuerte, es la libertad la que oprime y la ley la que libera". (H 1979;46-50)

Justamente, como el discurso referido en este género cumple en gran medida la función de reconocimiento de otra fuente y aporta autoridad a los conceptos emitidos, tanto las citas directas como indirectas en las que se trae la voz autorizada de la jerarquía eclesiástica, están introducidos por verbos anunciadores de cita positivos como instar, enseñar, recordar, destacar y otras expresiones, que cumplen con la misma función. Este fenómeno se observa con alta frecuencia en todas las homilías del corpus. A continuación reproducimos fragmentos tomados de homilías de dictadura (1976, 1979), principios de democracia $(1987,1993)$ y del período más reciente $(2007)$ :

Por esas razones el Concilio Vaticano II enseña que los ciudadanos deben cultivar, con magnanimidad y lealtad el amor a la patria, pero sin estrechez de espíritu, de modo que al mismo tiempo siempre miren por el bien de toda la familia humana (Cfr. G.S.75) e insiste que ese amor a la patria debe ser verdadero y eficaz (Cfr. A.G.15), de modo que en los cristianos su originalidad de ser hombres nuevos nacidos en Cristo debe manifestarse en la cultura y tradiciones de su propia nación (Cfr. A.G. 21). (H 1976 ; 46-51)

La Paz, para decirlo con palabras de Juan XXIII tomadas de la maravillosa encíclica "Pacem in Terris", será una palabra vacía si no está fundada en el orden moral y por tanto ha de estar cimentada sobre la verdad, construida con las normas de justicia, vivificada e integrada por la caridad y realizada, en fin, con la libertad. (H 1979; I 115-118)

Nos toca vivir la enorme gracia de la visita del Santo Padre. El nos habló a los católicos. Pero destacó también que hablaba a todos los argentinos.

Nos dio su mensaje que se manifiesta en el orden político, social, económico y nos enseñó que "descubriendo a Cristo" descubrimos la dignidad más honda del Hombre, y que es en Cristo donde encontramos el sentido más profundo de todas las realidades temporales y de las relaciones entre los hombres.

(H.1987 I 38-43)

$Y$ no viene mal recordar a este respecto que recientemente, nuestro actual Sumo Pontífice, instaba a "la fidelidad a la democracia, ya que es la única que puede garantizar la igualdad y los derechos de todos". En efecto, se da una especie de dependencia recíproca entre democracia y justicia, que impulsa a todos a comprometerse de modo responsable para que se salvaguarde el derecho de cada uno, especialmente de los débiles o marginados. $(\mathrm{H}$ 2007; I 195-200) 
Vemos en los fragmentos arriba reproducidos que el locutor busca generar en la audiencia una actitud de escucha atenta no solo utilizando verbos para introducir las citas de encíclicas o documentos de la Iglesia, sino con expresiones con una gran cuota de autoridad como para decirlo con palabras de..., nos dio su mensaje o $Y$ no viene mal recordar y adjetivos como maravillosa. En todo momento Invita a sumar las voluntades de todos y a acordar con los conceptos expuestos.

También en la homilía del año 2008 se detectó cómo el locutor, cuya postura coincide con la del emisor citado, opta por fusionar el discurso atribuido con discurso actual sin hacer alusión alguna a la fuente, que sólo queda mencionada en la versión escrita con una nota al pie.

"Sabemos que una Nación es una comunidad de personas que comparten muchos bienes, pero, sobre todo, una historia, una cultura y un destino común. Por ello debemos volver a la raíz del amor que teje la convivencia social, entendida como un Ilamado de Dios" (2) CEA, La Nación que queremos, 28 de septiembre del 2002, № 5 (H 2008; I 86-89)

Otra forma de traer el discurso referido al texto actual es mediante la reformulación de las palabras originales, con lo cual se unifica la voz del locutor con aquella invocada. En el fragmento de la homilía del año 1976 citado a continuación, el locutor reproduce en estilo indirecto conceptos emanados del Concilio Vaticano II, de este modo se acerca a la audiencia ya que simplifica el discurso algo oscuro de los documentos de la Iglesia:

Por esas razones el Concilio Vaticano II enseña que los ciudadanos deben cultivar, con magnanimidad y lealtad el amor a la patria, pero sin estrechez de espíritu, de modo que al mismo tiempo siempre miren por el bien de toda la familia humana (Cfr. G.S.75) e insiste que ese amor a la patria debe ser verdadero y eficaz (Cfr. A.G.15), de modo que en los cristianos su originalidad de ser hombres nuevos nacidos en Cristo debe manifestarse en la cultura $y$ tradiciones de su propia nación (Cfr. A.G. 21). (H1976; I 46-51)

En la homilía del año 2003, vemos cómo el emisor reformula las palabras actuales del gaucho Martín Fierro, poema narrativo de género gauchesco, y, mediante el estilo indirecto, hace propia esa voz. 
La poética profecía del Martin Fierro debe prevenirnos: nuestros eternos y estériles odios e individualismos abren las puertas a los que nos devoran de afuera. ( H 2003; I 99-101)

En el siguiente fragmento, tomado de la homilía del año 2004 el emisor reformula los conceptos del mismo poema gauchesco y se apropia de esa voz:

La propuesta es liberarnos de nuestra mediocridad, esa mediocridad que es el mejor narcótico para esclavizar a los pueblos. No hacen falta ejércitos opresores. Parafraseando a nuestro poema nacional podemos decir que un pueblo dividido y desorientado ya está dominado. (H 2004;l 187-190)

Lo mismo ocurre en la homilía del año 1993 en la que se recurre a la cita indirecta para exponer las enseñanzas de Tomás de Aquino.

Tomás de Aquino enseña que la violencia del poderoso y la falsa prudencia del sabio corrompen la justicia. (H 1993; 71-73)

Sin embargo, en la homilía del año 1976, el emisor opta por la cita directa dotando al discurso, a nuestro entender, de una fuerza retórica mayor en el sentido que al ser discurso de una autoridad en una institución puramente tomista como la Iglesia Argentina, esas palabras cobran carácter de inapelables y, justamente son ubicadas debajo de las enseñanzas nada menos que de Dios.

Después de Dios, nos enseña Santo Tomás de Aquino, "el hombre en el orden natural está obligado y es deudor a sus padres y a su patria”. (H 1976; I 12-13)

Con la misma intención, en la homilía del año 2005 el locutor utiliza una cita textual de palabras de un reconocido escritor argentino, Eduardo Mallea, para construir su argumento, poco claro a nuestro entender, considerando el contexto de situación. Al optar por este tipo de reflexión de alto vuelo intelectual vemos que el locutor, sin proponérselo, llegará solo a aquel sector de la audiencia capaz de comprender su lenguaje metafórico.

Escribía Eduardo Mallea: "Haberse originado es originarse constantemente, nacer es seguir naciendo, y si no sabemos cómo y para qué llevamos en nosotros tan constantes nacimientos, esta ignorancia adquirirá, bajo el aspecto 
de una vida que se perpetúa, el valor de una muerte que se repite" (3). (H 2005; 22-25)

En algunos de los textos reproducidos hasta aquí, vemos que la extravocalización, o sea la apelación a la palabra tomada del Evangelio como la Palabra de Dios, es más fuerte que una afirmación categórica. La voz que se trae se confunde a veces con la del locutor. Si bien se incorpora una voz externa al discurso actual nunca se lo hace para traer posturas alternativas sino para dar mayor autoridad a la voz del locutor, quien asume, de este modo, una postura hegemónica.

Hemos visto hasta acá que aquellos fragmentos, coincidentes en su mayoría con la etapa de fundamentación ideológica, están construidos sobre voces externas tomadas de la doctrina, y responden más a una función dogmática y prescriptiva que los mencionados anteriormente. En términos de White (2003), hablamos de recursos de extra-vocalización de "respaldo". En los extractos reproducidos a continuación observamos cómo los emisores se introducen en el texto como fuente responsable del enunciado.

La Iglesia, que es madre en el orden sobrenatural, siempre ha inculcado el verdadero amor a la patria siguiendo los ejemplos de Nuestro Señor Jesucristo, quien, además de amar profundamente a la patria terrena, se sometió a sus leyes. (H. 1976;I 27-29)

Nuestro país vive hoy momentos muy especiales, trascendentales...las generaciones futuras esperan que seamos capaces de transitarlos con grandeza y que seamos así fieles a la herencia de los próceres. (H 1987; I 3436)

La parábola del Buen Samaritano es un ícono iluminador, capaz de poner de manifiesto la opción de fondo que debemos tomar para reconstruir esta Patria que nos duele. (H 2003; I 31,32)

En los tres casos, las afirmaciones categóricas expresan que lo expuesto es una creencia compartida. En el primer extracto, tomado de la homilía del año 1976, se hace una exposición acerca de la función de la Iglesia, en el segundo se menciona la situación del país y en el último se hace un paralelo entre la lectura del Buen Samaritano (Lc. 10, 25-37) y la conducta a seguir para la reconstrucción de la patria. 
Con la misma intención de exponer conceptos compartidos por todos los creyentes, el locutor hace referencia a pasajes de la Biblia pero ya no recurriendo a la afirmación categórica sino a la negación:

No tenemos derecho a la indiferencia y al desinterés o a mirar hacia otro lado. No podemos "pasar de largo" como lo hicieron los de la parábola. $(\mathrm{H} 2003$; I 186-7)

Zaqueo no optó por la resignación frente a sus dificultades, no cedió su oportunidad a la impotencia, se adelantó, buscó la altura desde donde ver mejor, y se dejó mirar por El Señor.(H 2002; I 70-72)

Otro recurso que utiliza con mucha frecuencia el locutor para dar a conocer que lo expuesto es conocimiento compartido por todos, es el de los marcadores de evidencia (Gili Gaya, 1980).

Todos saben que ante la entrada en el tercer milenio, el Papa ha convocado a la Iglesia para la celebración de un Jubileo en el año 2000; y en un documento ha lanzado las líneas para una cabal preparación durante los años que concluyen el sigo XX. ( H 1996; 29-31)

Es un hecho ya advertido en la inmediata post-guerra, la globalización que algunos Ilaman "mundialización". (H1996; I 109-110)

Sin duda que hay muchos valores cristianos que están en condiciones en nuestra querida Patria Argentina, y hoy más que nunca se exige prudencia y sabiduría para descubrirlos y respetarlos. (H 1987; 28-30)

Sabemos bien que la felicidad plena no se obtiene por el dinero, el poder, la fama, el placer o cualquiera de sus sustitutos (H 2007; । 92-93)

En los párrafos reproducidos a continuación, observamos cómo el locutor utiliza la primera persona del singular, hecho poco habitual puesto que un celebrante tiende a utilizar el plural mayestático ${ }^{31}$ que le confiere autoridad y transforma sus afirmaciones en enunciados inapelables. Sin embargo, esa primera persona del singular aparece atenuada con la expresión permítaseme o en mi insignificancia me permito que expresa que lo que va a exponer es una opinión suya como locutor pero que necesita pedir autorización a su audiencia. Es decir que la primera persona lo ubica como protagonista pero se hace

\footnotetext{
${ }^{31}$ RAE Disponible en : http://buscon.rae.es/draeI/SrvltObtenerHtml?origen $=$ RAE \&LEMA $=$ plural \&SUPIND $=0 \& C A R E X T=1000$ 0\&NEDIC=No [consulta 4/1/2012]
} 
necesaria la aprobación de los interlocutores, logrando de este modo un acercamiento con ellos.

\begin{abstract}
Permítaseme recordar en esta magna celebración eucarística, aquella permanente e invariable enseñanza del magisterio de la Iglesia que, desde los primeros padres hasta nuestros días, pasando por los grandes documentos pontificios ha proclamado con toda explicitud como lo ha hecho el Concilio Vaticano II, que "Dios ha destinado la tierra y cuanto en ella se contiene para uso de todos los hombres y de todos pueblos, de modo que los bienes creados la caridad."(H 1979; I 22-28)
\end{abstract}

En mi insignificancia me permito, a modo de conclusión, recordar el Salmo 46 que exalta el triunfo de Yahvé a toda esta solemne asamblea de gobernantes y obispos, de soldados y embajadores: el Señor es sublime y terrible. Emperador de toda la tierra; Dios es el Rey del mundo... de Dios son los grandes de la tierra...sólo Él es excelso..."(H 1980; I 108-111)

En la homilía del año 1996, Monseñor Quarracino utiliza la primera persona del singular para citarse a sí mismo, algo que no se observa en los otros textos. En modo similar al fragmento de la homilía del año 1980, utiliza el verbo permitir en forma reflexiva (me permito) pero no produce el mismo efecto ya que, en primer lugar, el permiso se lo concede a sí mismo, no lo pide, y en segundo lugar, sale de la autocita con la frase sigo pensando lo mismo para luego dirigirse a la audiencia formulando el interrogante ¿Será este nuestro pecado nacional?

\begin{abstract}
Mucho se ha escrito sobre la Argentina en los últimos cuarenta años; fueron autores nuestros y también extranjeros. Me he preguntado si de toda esa literatura se podrá extraer una imagen acabada, certera y justa. En este momento recuerdo que en alguna oportunidad tuve la ocasión de referirme a esta entrañable argentina como el país de las oportunidades perdidas $y$, con un lenguaje que yo mismo calificaba de excesivo, el país de las excelencias decapitadas o veneraciones hinchadas por excesivas. Aducía razones de lo primero, que no expondré aquí y ahora; con lo segundo quería decir que parecería que si alguien en distintos aspectos de la sociedad se constituía en figura destacada, de primer nivel, o se lo decapitaba-atacándolo- o se 10 rodeaba de olvido y silencio, 0 , por el contrario, se sobrevaloraban mediocridades. Me permito decir que, pasados unos años, sigo pensando lo mismo. ¿Será éste nuestro pecado nacional? Al menos merece un examen de conciencia. ( H 1996; I 16-27)
\end{abstract}

Nos hemos detenido en el aspecto retrospectivo del texto dentro de la perspectiva polifónica que tiene que ver con el traer voces anteriores al 
discurso presente. En el caso de la atribución de la información en las homilías, cuando el celebrante se atribuye la información a sí mismo puede estar citando de manera encubierta a fuentes que mantiene en reserva, o que, por convenciones del género, no es necesario explicitar ya que se suponen de público conocimiento.

Cuando el emisor decide traer a su discurso voces pasadas, no efectúa una simple reproducción de discurso, sino una reconstrucción más o menos fiel, donde siempre están su voz y su postura ideológica que se manifiestan tanto en las transformaciones efectuadas a las palabras originales como en el verbo anunciador de la cita elegido. Utilizando conceptos de Goffman tomados de Behavior in Public Places (1963), en las diferentes situaciones de interacción todo individuo se presenta a sí mismo, a través de sus acciones comunicativas. Dicha acción tiene como finalidad presentar un determinado perfil de persona caracterizada por ciertos atributos positivos. Su intención es que tal pretensión de identidad sea tomada seriamente y, con tal fin, busca gestionar y controlar lo más posible - mediante sus acciones y comportamientos - la imagen que los otros construyen de él. Por tanto, la acción social siempre es actuación, representación para un público, y esto constituye un aspecto esencial de su sentido social. Goffman describe el esfuerzo y las estrategias que activan los individuos para presentar una imagen idealizada de sí mismos, esto es, ventajosa para ellos y veraz para los otros. En esta perspectiva, el actor social, como tradicionalmente ha sido concebido por la sociología (como actor portador de roles), se convierte en un actor en el sentido propio de la metáfora dramatúrgica. $Y$ más en este caso en el que ese actor, el celebrante en las homilías, sigue un guión ya escrito en gran parte por otros.

También consideramos necesario mencionar las señales previas que los emisores proporcionan respecto de cómo esperan que sus receptores reaccionen frente a su discurso. Con esta anticipación, los emisores construyen y negocian la solidaridad de sus receptores modelo. Cabe señalar, que la relación de solidaridad que se construye en el discurso no significa, sin embargo, la búsqueda de la total conformidad de la audiencia sino que, en este 
contexto, significa tolerancia hacia la diversidad de voces y puntos de vista, tanto reales como potenciales, que se activan en el texto.

Luego del análisis de recursos de intravocalización y extra-vocalización en los textos, podemos concluir que cuando el locutor recurre a la atribución lo hace con una actitud de reconocimiento respecto del discurso atribuido y se apoya en dicho discurso para aumentar la credibilidad del propio. Las proposiciones referidas son introducidas, en su mayoría, con verbos anunciadores de cita positivos que apuntan a incorporar las palabras y puntos de vista de voces externas que contribuyen a la postura asumida por el locutor. Estos fragmentos son evaluativos, puesto que la postura valorativa se presenta a la audiencia como algo que se da por sentado; no hay nada novedoso aunque sí polémico o pasible de ser cuestionado, resistido o rechazado (Martin y White 2005:93). En algunas homilías, el locutor busca desafiar a la audiencia posicionándose él mismo en lo que considera que "debería ser" frente a lo que la audiencia "es". En otras, el emisor construye y negocia la solidaridad de sus receptores ideales. Esto se observa cuando el hablante deja explícita su postura actitudinal e invita a la audiencia a respaldarla y compartirla. Sin embargo, en las homilías más polémicas la solidaridad no se construye con la audiencia real, que queda ubicada en posición antagónica, alineada con los "otros". En este género, el punto de vista de los otros frecuentemente no es aceptado. La postura ideológica institucional planteada es inamovible, no admite voces disidentes, aunque se las mencione para presentarlas como anti-modelo. Éste se presenta dentro del texto mediante la negación: el locutor explicita qué es lo que no se desea, lo que no se condice con la doctrina. De hecho White (2003) se refiere a los recursos de negación y contra-expectativa como aquellos que permiten al productor del texto anticiparse a cualquier duda o resistencia que pueda surgir por parte de su interlocutor, la audiencia en este caso. 


\subsubsection{El emisor frente a su audiencia}

White $(2000,2003)$, inspirado en Bajtín $(1981,1982)$ y en el trabajo de Martin (1997) y su categoría del Compromiso (Engagement), desarrolla una perspectiva social y dialógica. White (2003) plantea que el uso de los diferentes recursos lingüísticos (modalidad, polaridad, evidencialidad, vacilación, concesión, intensificación, atribución y consecuencialidad) depende de factores intersubjetivos que guardan relación con el reconocimiento o no por parte del hablante de posiciones alternativas a sus propias construcciones monoglósicas o heteroglósicas. Esto implica, como lo expresa Martin (2003), considerar tanto los significados de poder como los de solidaridad en el discurso en relación con los significados interpersonales.

Si bien la Iglesia recomienda que la homilía sea un discurso en el que el destinatario sea lo más amplio e indiferenciado posible, algunos manuales para sacerdotes la describen como "[...] una conversación sui generis en voz alta. Una conversación especial porque es uno solo el que habla, pero lo hace en una disposición tal que pueda ser teóricamente y prácticamente interrumpido por cualquiera de sus oyentes sin necesidad de que esa interrupción equivalga a una interpelación hostil" (AA. VV. 1994:42 en Bonnin 2009). Entendemos, entonces, que los textos son dialógicos aunque la audiencia no interrumpa al locutor y quede exclusivamente en sus manos la decisión de abrir o cerrar el espacio que se destina a dicho intercambio.

Hemos señalado que las afirmaciones categóricas, según señala White (2003), tienen una gran carga intersubjetiva ya que niegan o suprimen la diversidad de voces en la que están ubicadas, pero sin recurrir a la negación explícita. La mayoría de los enunciados de las homilías en estudio contienen gran cantidad de afirmaciones categóricas que según White (2003) Martin y White (2005), son el recurso que más desactiva el potencial dialógico. Como recurso de los autores del género homilía, la cláusula declarativa contribuiría a reforzar en la audiencia las interpretaciones más aceptadas tanto de las lecturas bíblicas como de la realidad circundante y limitaría la posibilidad de otras posiciones y reflexiones más complejas. Es justamente por esta razón que la Teoría de la 
Valoración concibe a los enunciados monoglósicos como una manera de adoptar posturas socio-semióticas de gran fuerza retórica e interpersonal, que entran en relaciones de tensión con posibles enunciados alternativos e incluso contradictorios (White 2003 en Kaplan 2007).

(...) aquella permanente e invariable enseñanza del magisterio de la Iglesia que, desde los primeros padres hasta nuestro días, pasando por los grandes documentos pontificios ha proclamado con toda explicites como lo ha hecho el Concilio Vaticano II, que "Dios ha destinado la tierra y cuanto en ella se contiene para uso de todos los hombres y de todos los pueblos, de modo que los bienes creados deben llegar a todos en forma justa, según la regla de la justicia inseparable de la caridad. (H 1979; | 22-7)

Nos dio su mensaje que se manifiesta en el orden político, social, económico y nos enseñó que "descubriendo a Cristo" descubrimos la dignidad más honda del Hombre, y que es en Cristo donde encontramos el sentido más profundo de todas las realidades temporales y de las relaciones entre los hombres.( H 1987; I 40-43)

La oración es la prenda de esperanza que elevamos a Dios en todo momento de nuestra historia y de nuestra vida, ya que sabemos que Él nunca abandona a los que en Él se confían (H 2009; I 34-6)

Lo que se logra es el cierre del espacio dialógico enfatizando lo establecido, lo inapelable ante la frase: "Es palabra de Dios".

En cuanto a la postura heteroglósica, uno de los recursos utilizados para contraer el espacio dialógico que se manifiesta con más frecuencia en la etapa de evaluación es la negación y contra-expectativa o concesión. Mediante este recurso, el productor del texto se anticipa a cualquier duda o resistencia que pueda surgir por parte de sus interlocutores o lectores, las ajusta y luego las contradice (White 2003). Los fragmentos que se reproducen a continuación dan muestra de ello.

Zaqueo no optó por la resignación frente a sus dificultades, no cedió su oportunidad a la impotencia, se adelantó, buscó la altura desde donde ver mejor, y se dejó mirar por el Señor. (H 2002; I 74-76)

Como Cristo Redentor, que no tomó la gloria del joven revivido para sí, sino que lo devolvió a su ámbito, a su madre, así quienes detentamos alguna autoridad sirvamos a la comunidad. Cedamos el protagonismo a la comunidad, apoyando y sosteniendo a quienes se organizan en pos de sus fines. $(\mathrm{H} 2000$; 108-111) 
Como se señaló anteriormente, la negación es el recurso que más contrae el espacio dialógico y es en la etapa de evaluación de los textos analizados donde se manifiesta más frecuentemente. En los fragmentos citados, el emisor niega y por lo tanto se distancia de la creencia que podrían albergar algunos miembros de su audiencia respecto de las posibles actitudes a tomar frente a circunstancias dadas. En el primer fragmento, frente a la adversidad, el resignarse o ceder 0 , en el segundo, de tomar como propio el beneficio de poseer cierta autoridad.

En el párrafo reproducido a continuación, sin embargo, la negación cumple otra función ya que el locutor está reproduciendo un concepto emanado del magisterio de la Iglesia que es inapelable. Las frases no constituye para nadie y no hay ninguna razón no dejan espacio al interlocutor siquiera a pensar que el concepto expresado podría ser interpretado de otra manera. En definitiva, esa es la función de la doctrina o el magisterio: no dejar lugar a dudas.

(...) frente a los ataques socializantes, no con menos énfasis ha afirmado que " la propiedad privada no constituye para nadie un derecho incondicional y absoluto, que no hay ninguna razón para reservarse en uso exclusivo lo que supera a la propia necesidad cuando a los demás les falta lo necesario". (H19 79;। 78-81)

Del mismo modo, en los siguientes párrafos se evalúa un estado de cosas en el que la negación - siguiendo el patrón negación + conjunción adversativa sino está en directa contradicción con la expectativa que se invoca. Observamos que con dicho recurso se refuerza el juicio negativo con que se censura a la clase dirigente por su falta de credibilidad:

Hoy, en medio de los conflictos, este pueblo nos enseña que no hay que hacerle caso a aquellos que pretenden destilar la realidad en ideas, que no nos sirven los intelectuales sin talento, ni los eticistas sin bondad, sino que hay que apelar a lo hondo de nuestra dignidad como pueblo, apelar a nuestra sabiduría, apelar a nuestras reservas culturales . (H 1999; I 162-166) (El subrayado es del autor)

Todos sabemos que en la hora actual el país tiene muchos problemas que resolver. Quizás no recordamos que ello no sucederá sin el esfuerzo de todos, 
sin egoísmos ni cerrazones mentales. No es con agravios como se resuelven los problemas, sino con apertura de mente y corazón. (H 1996; I 104-107)

Hay casos extremos en que la contracción dialógica efectuada por la negación parecería producir efectos muy similares a la monoglosia. En los dos fragmentos tomados de las homilías del año 1999 y 1996 se niega lo que no debe ser para luego introducir el camino a seguir encabezado por la conjunción "sino". En la siguiente frase esta conjunción se reemplaza por los dos puntos que cumplen la misma función de anticipar lo que el locutor considera la conducta a seguir:

Hacer este examen de conciencia no es una expresión de masoquismo o un camino al pesimismo: creo que es un verdadero acto de patriotismo. (H 1996; 67-69)

La contra-expectativa o contraposición de segmentos dentro de la oración se manifiesta mediante el uso de conectores adversativos (pero, aunque, mas) así como locuciones adverbiales (sin embargo, no obstante) que operan como conectores del discurso (Gómez Torrego, 1997:237), con los cuales se establece el equilibrio entre aquello que "es" y no "debería ser" y lo que "debe ser". Esta estructura, que observamos en los extractos reproducidos a continuación, se repite con muy alta frecuencia en todos los textos del corpus en estudio.

Para esto, como Cristo, hay que atreverse a renunciar al poder que acapara y enceguece, y aceptar ejercer la autoridad que sirve y acompaña. Unos pocos tienen el poder de las finanzas y la técnica; otros ejercen el poder del Estado, pero sólo una comunidad activa, que se vuelve solidaria y trabaja mancomunada puede, en su creativa diversidad, impulsar la barca del bien común. ( H 2000; I 102-106)

La generosidad divina también se ha reflejado en el testimonio de vida de entrega y sacrificio de nuestros padres y próceres, del mismo modo que en millones de rostros humildes y creyentes, hermanos nuestros, protagonistas anónimos del trabajo y las luchas heroicas, encarnación de la silenciosa epopeya del Espíritu que funda pueblos.

Sin embargo, vivimos muy lejos de la gratitud que merecería tanto don recibido. ¿Qué impide ver esta llegada del Señor? ¿Qué torna imposible el; gustar y ver qué bueno es el Señor; (Sal. 34,9). ( H 2002; I 19-25)

Pero no hay que confundir el patriotismo con el chauvinismo que es la exageración de anteponer al propio país sobre todos los otros. Un patriotismo así acaba por ser patriotería. (H 1996; I 83-85) 
No obstante la crisis moral global que nos incluye, nuestra mirada es esperanzada y esperanzadora. (2009; I 87-88)

Así como los recursos arriba mencionados contraen el espacio dialógico, también pudimos observar la presencia de conjunciones y locuciones coordinantes consecutivas que operan en el mismo sentido. En los fragmentos reproducidos a continuación, vemos cómo las opciones del interlocutor se cierran cuando se indica en forma conclusiva el camino a seguir con afirmaciones absolutas:

Dice el salmista, y con él todos nosotros: "Te doy gracias Señor, de todo corazón..." y es justo y necesario que también hoy nosotros lo hagamos reconociendo a Dios como al que "hizo grandes cosas entre nosotros", porque Dios actúa en la historia. Y por tanto, la historia es el resultado conjunto de las acciones de los hombres, la acción de la naturaleza y la acción de Dios.

Por eso tiene sentido nuestra oración (súplica) y por eso tiene sentido nuestra acción de gracias. (H 1987; 3-9)

Como Cristo Redentor, que no tomó la gloria del joven revivido para sí, sino que lo devolvió a su ámbito, a su madre, así quienes detentamos alguna autoridad sirvamos a la comunidad. Cedamos el protagonismo a la comunidad, apoyando y sosteniendo a quienes se organizan en pos de sus fines. Así se quebrarán las barreras de la incomunicación que, paradójicamente, existe en este mundo supercomunicado. Así se acerca la cosa pública a sus verdaderos protagonistas, que ya no quieren hipotecar su suerte a sábanas de representantes desconocidos. (H 2000; | 108-114)

Pío XII se lamentaba que algunos en estos tiempos, temen mostrarse particularmente amantes de su patria y agregaba que este disminuido amor a la patria, a esta gran familia que Dios nos ha dado, es una señal de la actual desorientación de los espíritus (Cfr. AAS. 958, pág. 219)

Debemos, por tanto, cultivar un sano amor a la patria. A ello estimula la Iglesia a sus hijos (. H 1976; I 32-37)

Por ello el mismo San Pablo que nos dice: aquí no tenemos "morada permanente" proclama con orgullo su condición de israelita y proclama las posibilidades de salvación de su pueblo (2 Cor 11, 22/Rm.11,1 y sg)(H 1996; I 98-100)

Muchos de los problemas de hoy pueden tener su origen en el pasado, pero lo más importante es entender a dónde nos llevará la situación actual. Por eso a la gente le gustan las profecías y vaticinios, aunque la mayoría de las veces se trate de puras opiniones. La única profecía cierta es que Cristo es el sentido de toda la historia. En él debemos crecer como Patria. (H 2006; 72-75) 
Del análisis que hasta aquí se llevó a cabo, pueden extraerse algunas conclusiones. En primer lugar, el emisor muestra una tendencia muy marcada a contraer el espacio dialógico al evaluar a las personas y sus conductas de modo tal que el discurso tenga un efecto similar al de la monoglosia. Esto se logra mediante la negación y la concesión muy frecuentes en todos los textos. La mayoría de las evaluaciones, en especial las negativas, se presentan de manera casi absoluta, sin reconocer la posibilidad de un debate entre voces y puntos de vista diferentes en el espacio dialógico. Frente a la audiencia, el emisor se construye a sí mismo como poseedor de un estatus y de una autoridad moral que le permite no solo juzgar su conducta sino hacerlo de tal manera que ignora o suprime puntos de vista alternativos.

También estamos en condiciones de afirmar que, en las homilías más polémicas, el emisor asume el rol de representante de una voz social opositora a la de la clase dirigente que también se encuentra dentro de su audiencia. Nuestro análisis se centró en los recursos utilizados por el emisor quien, por un lado, evalúa negativamente al otro en el discurso y asume como propia la voz del pueblo que habitualmente no se escucha porque, a su entender, obedece a la moral cristiana. Este hecho marca una característica propia del género que nos ocupa puesto que, como ya expusimos en otras oportunidades, su función global es la de exhortar e invitar al cambio partiendo de una situación que se plantea como poco deseable y reñida con los dictados de la fe cristiana. Los argumentos, entonces, estarían estructurados tomando como punto de partida la denuncia de personas y conductas identificadas con la clase política, los medios o quienes ostentan el poder para luego mostrar el modelo a seguir encarnado en el pueblo. 


\subsection{El Juicio}

Así como nos referimos al dominio semántico del Compromiso para analizar el posicionamiento de la voz del hablante o productor de los textos que componen el corpus, también consideramos de sumo interés hacer una breve incursión en el dominio de la Actitud que incluye los significados por los cuales ese mismo hablante o productor evalúa a los participantes, procesos y circunstancias (Halliday, 1994). Nos centraremos, en particular, en el subsistema de Juicio puesto que los valores de juicio tienen una incidencia especial en los textos. Lo prescriptivo, o sea, la norma sobre cómo deben y no deben comportarse las personas, ocupa segmentos importantes en los textos. Particularmente en los textos más polémicos, los personajes pasibles de evaluación son las autoridades presentes en la celebración, y el pueblo que también conforma la audiencia aunque no en forma presencial.

Como ya dijimos, el subsistema actitudinal del Juicio (Martin y White 2005) comprende significados con los que se evalúa positiva o negativamente el comportamiento humano, en relación con un conjunto de normas institucionalizadas, hecho que se reitera en distintos fragmentos de las homilías analizadas, en particular aquellos que corresponden a la etapa de evaluación. Las normas sociales y morales que se ponen en juego en las evaluaciones de juicio dentro de los textos analizados adoptan la forma de reglas, o de expectativas sociales y sistemas de valor condicionados por la cultura generada dentro del marco institucional de la Iglesia. Así, con el Juicio se puede evaluar el comportamiento como moral o inmoral, legal o ilegal, socialmente aceptable o inaceptable, normal o anormal, etc. Tomando estos conceptos en cuenta, esta categoría de Juicio puede, a su vez, clasificarse en dos categorías: de "estima social" y los de "sanción social" (Martin y Rose 2005).

Como ya señalamos, el subsistema de Juicio está supeditado a la situación cultural e ideológica particular en la que se emite, vale decir, que el modo en que se evalúa la moralidad, la legalidad, la capacidad u otra característica de la 
conducta humana dentro de la homilía estará determinado por la cultura y posición ideológica del celebrante, que en el caso de la ceremonia del Tedeum es, en la mayoría de los casos, un representante de la voz oficial de la Iglesia, miembro de la Conferencia Episcopal. Sin embargo, el hecho de que la audiencia así como el celebrante y la postura de la Iglesia frente al gobierno vayan cambiando hace que ese discurso se vea modificado sustancialmente a lo largo de los años.

Homilías de 1976 a 1980

En las homilías que se emitieron entre los años 1976-1980, coincidentes con el gobierno de facto, los juicios son muy escasos y solo se orientan, cuando se puede identificar el sujeto evaluado, al pueblo y su relación con la patria, como podemos observar en la homilía del año 1976, o a aquellos que comulgan con otras ideologías como en la homilía del año 1979 en la que se hace referencia al marxismo o al liberalismo. Si bien entendemos que la evaluación se hace mediante recursos de Apreciación, ya que en apariencia se habla del constructo abstracto marxismo/ liberalismo, en definitiva está colaborando con el juicio emitido hacia personas. Vale decir, que cuando el locutor rechaza al marxismo materialista y ateo por ser realizador de una dialéctica de violencia, negador al mismo tiempo de la libertad individual y de toda trascendencia del hombre (H 1979; I 72-3), lo que interpretamos es que está hablando de los "miembros de la guerrilla", tildados por la iglesia como "marxistas" que ejercen la violencia y niegan la libertad así como la visión trascendente del hombre.

Recién en la última homilía de este período se identifica el sujeto evaluado - el pueblo o el papa- cuando se trata de juicios de elogio positivos mientras que no ocurre lo mismo cuando se trata de valores negativos de juicios de sanción social.

En los cuadros adaptados de Martin y Rose (2003) que presentamos a continuación, se pueden apreciar diferentes categorizaciones del subsistema de Juicio presentes en los texos correspondientes a este período: 


\begin{tabular}{|c|c|}
\hline \multicolumn{2}{|r|}{$\begin{array}{l}\text { Juicio de sanción social } \\
\qquad(1976-1980)\end{array}$} \\
\hline Quién & Valoración negativa \\
\hline 1976 & No se registra. \\
\hline $\begin{array}{l}1979 \\
\text { marxismo } \\
\text { materialista y la } \\
\text { ideología liberal }\end{array}$ & $\begin{array}{l}\text { Rechazado, ateo, violencia, negador de la libertad individual y de toda trascendencia del } \\
\text { hombre, interés del poder, ataques socializantes. }\end{array}$ \\
\hline $\begin{array}{l}1980 \\
\text { No se especifica }\end{array}$ & $\begin{array}{l}\text { Luchas entre hermanos, reyertas fratricidas, períodos negros y rojos, accesos de } \\
\text { ferocidad, atacan, entenebrecen. }\end{array}$ \\
\hline
\end{tabular}

Cuadro 4.3: Juicio sanción social:Valores negativos más representativos

\begin{tabular}{|l|l|l|}
\hline \multicolumn{3}{|c|}{$\begin{array}{c}\text { Juicio de estima social } \\
\text { (1976- 1980) }\end{array}$} \\
\hline Quién & Valoración positiva & Valoración negativa \\
\hline $\begin{array}{l}\mathbf{1 9 7 6} \\
\text { Aquellos }\end{array}$ & No se registra & $\begin{array}{l}\text { Lamentar, temer, disminuido amor a la patria, } \\
\text { desorientación de los espíritus }\end{array}$ \\
\hline $\mathbf{1 9 7 9}$ & No se registra & No se registra \\
\hline $\begin{array}{l}\mathbf{1 9 8 0} \\
\text { Nuestro pueblo } \\
\text { Padrentino/ Santo Juan Pablo } \\
\text { II }\end{array}$ & $\begin{array}{l}\text { Vibrar religiosamente, implora a } \\
\text { Dios, le alaba, canta, pide perdón, } \\
\text { da gracias. }\end{array}$ & No se registra \\
& $\begin{array}{l}\text { Espíritu de reconciliación nacional, } \\
\text { mediación providencial, gestión de } \\
\text { paz, éxito anhelado por todos. }\end{array}$ & \\
\hline
\end{tabular}

Cuadro 4.4: Juicio de estima social: Valores positivos y negativos más representativos

Homilías de 1987 a 1996

Este período de transición a la democracia se caracteriza por una incipiente aparición de valores de juicio dirigidos al pueblo, los próceres, la historia reciente y quienes ejercen el poder, como los partidos políticos, las agrupaciones y el periodismo. En gran parte se trata de fragmentos breves, especialmente si los comparamos con la etapa que le sigue, en los que predomina la evaluación negativa. En la homilía de 1996 no se registraron valores positivos, sin embargo podríamos decir que es el primer texto que presenta fragmentos de evaluación negativa hacia agentes explícitos, hecho que se va a ir consolidando en las homilías correspondientes al período 19992004. 
En los siguientes cuadros adaptados de Martin y Rose (2003) se identifican los recursos léxicos utilizados en los textos de este período para emitir los valores de Juicio.

\begin{tabular}{|l|l|}
\hline \multicolumn{2}{|c|}{$\begin{array}{c}\text { Juicio de sanción social } \\
\text { ( 1987-1996) }\end{array}$} \\
\hline Quién & \multicolumn{1}{c|}{ Valoración negativa } \\
\hline $\begin{array}{l}\text { Nuestra historia } \\
\text { reciente / nosotros/ } \\
\text { Patria }\end{array}$ & $\begin{array}{l}\text { Confusión, violencia, desencuentro, gran dolor, sufrimiento, cuesta superar. } \\
\text { Desorientados, abatidos. }\end{array}$ \\
\hline $\begin{array}{l}\mathbf{1 9 9 3} \\
\text { El poderoso / el } \\
\text { sabio }\end{array}$ & Violencia, falsa prudencia, corrompen la justicia. \\
\hline $\begin{array}{l}\mathbf{1 9 9 6} \\
\text { partidos políticos/ } \\
\text { clase empresaria/ } \\
\text { el periodismo/ } \\
\text { asociaciones } \\
\text { gremiales, } \\
\text { culturales, sociales }\end{array}$ & $\begin{array}{l}\text { Demagogia, mentira, favoritismos engañosos, ideologizados, herir, soez, mentira, } \\
\text { calumnia, agravios, egoísmos, cerrazones mentales. }\end{array}$ \\
\hline \begin{tabular}{l} 
Cuadro 4.5: Juicio de sanción social: Valores negativos más representativos \\
\hline
\end{tabular}
\end{tabular}

\begin{tabular}{|l|l|}
\hline \multicolumn{2}{|c|}{$\begin{array}{c}\text { Juicio de estima social } \\
\text { (1987-1996) }\end{array}$} \\
\hline Quién & \multicolumn{1}{c|}{ Valoración positiva } \\
\hline $\begin{array}{l}1987 \\
\text { nuestros próceres } \\
\text { de mayo }\end{array}$ & Iluminados, presencia, cristiana. \\
\hline $\begin{array}{l}1993 \\
\text { un pueblo }\end{array}$ & Libertad, prosperidad, justicia, fraternidad, oportunidades, calidad de vida, todos. \\
\hline 1996 & No se detecta \\
\hline
\end{tabular}

Cuadro 4.6: Juicio de estima social: Valores positivos más representativos

Homilías de 1999 a 2004

Para al análisis de la categoría Juicio, nos hemos detenido muy especialmente en las homilías más polémicas, correspondientes al período 1999 al 2004, ya que la construcción discursiva tanto de las autoridades como del pueblo los ubica en posición antagónica: mientras se evalúa negativamente a las autoridades, el pueblo es evaluado positivamente además de ocupar gran parte de los textos. Reproducimos a continuación fragmentos en los que se ponen en evidencia los valores de juicio tanto positivos como negativos dirigidos a los actores sociales mencionados: 
El pueblo de nuestra Nación demuestra, una y otra vez, la clara voluntad de responder a su vocación de ser buenos samaritanos unos con otros: ha confiado nuevamente en nuestro sistema democrático a pesar de sus debilidades y carencias, y vemos cómo se redoblan los esfuerzos solidarios para volver a tejer una sociedad que se fractura. Nuestro pueblo responde con silencio de Cruz a las propuestas disolutorias y soporta hasta el límite la violencia descontrolada de quienes están presos del caos delincuencial. $(\mathrm{H}$ 2003; 1 100-105)

Hemos visto avanzar en nuestra Patria las densas sombras del abandono, de la violencia utilizada para mezquinos intereses de poder y división, también existe la ambición de la función pública buscada como botín.( H 2003I 90-93)

El cáliz del trabajo solidario en el servicio es la respuesta más genuina a la incertidumbre de un país lleno de potencialidades que no se realizan o se postergan una y otra vez, indefinidamente, deteniendo su derrotero de grandeza. Es la respuesta a la incertidumbre de un país dañado por los privilegios, por los que utilizan el poder en su provecho a cuenta de la legitimidad representativa, por quienes exigen sacrificios incalculables, escondidos en sus burbujas de abundancia, mientras evaden su responsabilidad social y lavan las riquezas que el esfuerzo de todos producen; por los que dicen escuchar y no escuchan, por los que aplauden ritualmente sin hacerse eco, por los que creen que se habla para otros. (H 2001;l 110-118)

Los argentinos marchamos por nuestra historia acompañados por el don creado de las riquezas de nuestras tierras y por el Espíritu de Cristo reflejado en la mística y el esfuerzo de tantos que vivieron y trabajaron en este Hogar, en el testimonio silente de los que dan de su talento, su ética, su creatividad, su vida. (a) ;Este pueblo comprende hondamente lo que significa el amor a su tierra y la memoria de sus convicciones más profundas! En su religiosidad más íntima, en la siempre espontánea solidaridad, en sus luchas e iniciativas sociales, en su creatividad y capacidad de goce festivo y artístico, se refleja el Don de Vida del Resucitado. (b) Porque somos un pueblo capaz de sentir nuestra identidad más allá de las circunstancias y adversidades, somos un pueblo capaz de reconocernos en nuestros diversos rostros. Tanto talento no siempre se ha visto acompañado por proyectos con continuidad en el tiempo, ni logró convocar siempre la conciencia colectiva. $Y$, por ello, como los discípulos huidizos, podemos encontrarnos acaparados por cierta amargura en nuestra marcha, fatigados por problemas que no dejan vislumbrar la urgencia de un futuro que nunca parece llegar.(H 1999; I 58-71)

En la cita anterior, vemos varios indicios de juicio: (a) por un lado el elogio explícito al pueblo al que el locutor se refiere en tercera persona y (b) la incorporación del locutor, mediante el uso de la primera persona del plural al pueblo evaluado positivamente (somos un pueblo ...). Por otro lado, se detecta una expresión implícita de juicio en la cual una mención en apariencia fáctica, no evaluativa, de una situación de hecho como se expresa en: Tanto talento no 
siempre se ha visto acompañado por proyectos con continuidad en el tiempo, ni logró convocar siempre la conciencia colectiva desencadena una evaluación actitudinal no solo de quien está escuchando el mensaje sino también del pueblo al que se elogia por su amor a la tierra, su ética, talento, creatividad, solidaridad etc. pero que no encuentra respuesta en sus gobernantes. Hemos observado también el uso frecuente de la gradación para referirse al pueblo que está lleno de amargura, que es más que triste y fatigado por problemas, es decir, más que cansado, esperando con urgencia que es más que apuro ese futuro que nunca parece llegar oponiéndolo a su siempre espontánea solidaridad.

De acuerdo a lo expresado, podríamos concluir que desde el año 1999 hasta 2004 los juicios se caracterizan de la siguiente manera: estima y sanción social de normalidad, capacidad, tenacidad, veracidad e integridad moral positiva para evaluar al pueblo y de estima y sanción social de capacidad, tenacidad, veracidad e integridad moral negativa hacia las autoridades y grupos de poder.

Los siguientes cuadros adaptados de Martin y Rose (2003) muestran y ejemplifican diferentes categorizaciones del subsistema de Juicio presentes en los texos correspondientes al período 1999-2004:

\begin{tabular}{|l|l|}
\hline \multicolumn{2}{|c|}{$\begin{array}{c}\text { Juicio de estima y sanción social } \\
\text { (1999-2004) }\end{array}$} \\
\hline Quién & \multicolumn{1}{c|}{ Valoración positiva } \\
\hline $\begin{array}{l}\text { 1999: } \\
\text { Pueblo } \\
\text { argentino/los } \\
\text { argentinos/ } \\
\text { nuestros hombres } \\
\text { y mujeres }\end{array}$ & $\begin{array}{l}\text { Talento, ética, creatividad, amor a su tierra, religiosidad, solidaridad, capacidad de goce } \\
\text { festivo, acaparados de amargura, fatigados por problemas, trabajo fraterno, heroísmo, } \\
\text { amistad política de convivencia racial y social, de fe, grandeza, dignidad, Patria, familia, } \\
\text { rescoldo de memoria, dispuesto,memoria colectiva }\end{array}$ \\
\hline $\begin{array}{l}\text { 2000 } \\
\text { Marginados del } \\
\text { sistema/votantes } \\
\text { potenciales/ } \\
\text { nuestros jóvenes/ } \\
\text { comunidad/ } \\
\text { nuestros ancianos }\end{array}$ & $\begin{array}{l}\text { Esperanza, magnánimo, don de la libertad, heroicos, pacificar, dignidad, alegría, paz, } \\
\text { júbilo, vínculos, humildad, fraternidad, lealtad a los principios, productividad, revolución, } \\
\text { transformación social, audaz y esperanzadora iniciativa, sonrisa de esperanza. }\end{array}$ \\
\hline
\end{tabular}




\begin{tabular}{|c|c|}
\hline $\begin{array}{l}2001 \text { nuestro } \\
\text { pueblo/ la } \\
\text { sociedad/ cada } \\
\text { investigador, } \\
\text { docente, maestro, } \\
\text { productor, joven } \\
\text { /los más pobres y } \\
\text { todos los que } \\
\text { trabajan/ } \\
\text { aborígenes/ } \\
\text { inmigrantes/ todos } \\
\text { los credos/ niños }\end{array}$ & $\begin{array}{l}\text { Servicio, vínculo social, reserva espiritual, dignidad, capacidad de trabajo duro y solidario, } \\
\text { serenidad aguantadora y esperanzada, corazón común, darse, bien común, confianza, } \\
\text { deseo de heroísmo, grandeza, espontánea, creativa,silenciosamente, entrega, aman a su } \\
\text { tierra, } \\
\text { reserva cultural y moral de nuestro pueblo, escuchan la palabra, de verdad, comprenden } \\
\text { que no se habla para otros. } \\
\text { Resistencia a la opresión, serenidad esperanzada, fe comunitaria, logros, futuro, resistir, } \\
\text { alma artística, amor, familia, derechos. }\end{array}$ \\
\hline $\begin{array}{l}2002 \\
\text { La sociedad / los } \\
\text { Zaqueos } \\
\text { convertidos. }\end{array}$ & $\begin{array}{l}\text { Milagro,trabajo paciente, altura espiritual, bien común, dar, , corazón, generosa, acción } \\
\text { firma y perseverante, levantarse y dejarse mirar por Dios, humildad del servicio, grandeza, } \\
\text { conversión, conquista social, creatividad, celebración, escuchar y dialogar, ceder y } \\
\text { compartir , esperanza, alegría de compartir. }\end{array}$ \\
\hline $\begin{array}{l}2003 \\
\text { Hombres y } \\
\text { mujeres/comunidad } \\
\text { de argentinos/ } \\
\text { pueblo de nuestra } \\
\text { Nación / los } \\
\text { ciudadanos }\end{array}$ & $\begin{array}{l}\text { Lucha interna, identidad, clara voluntad, confiar, sistema democrático, silencio de Cruz, , } \\
\text { ponerse la patria al hombro. }\end{array}$ \\
\hline $\begin{array}{l}\mathbf{2 0 0 4} \\
\text { los pobres/ los } \\
\text { argentinos/los } \\
\text { pequeños/ } \\
\text { próceres, } \\
\text { prohombres, } \\
\text { artistas, científicos/ } \\
\text { cualquiera que } \\
\text { piense más allá del } \\
\text { discurso } \\
\text { dominante/ pueblo } \\
\text { fiel/ aborígenes/ } \\
\text { españoles/ criollos/ } \\
\text { inmigrantes. }\end{array}$ & $\begin{array}{l}\text { Despojo, lo sabio, luminosos, amor gratuito, solidario, desinteresado, confianza, entrega a } \\
\text { los demás, verdadera libertad, aceptación, verdades, virtudes y grandezas, sublimidad, } \\
\text { palabra sabia, sutil, sugerente, armonía de lo bello, trabajo modesto y humilde del talento. } \\
\text { Vitalidad, creatividad, intentos, reconstrucción, sendero humilde, sencillez, raíz de la } \\
\text { cultura, verdadera comida del espíritu, cimienta la comunión, pan, abrazar, misericordia, } \\
\text { sabiduría, comprende, perdona todo, pan, sapiencial constancia, humano concreta, crece, } \\
\text { trabajo del espíritu, sensible, creativo, amor a Dios, no se ata a razas, ayudar, disfrutar, } \\
\text { alegría, identidad. Humilde, machacar diario, apostar al bien, silencio, pacífico, confiada } \\
\text { espera, reconfortante y fortalecedor, proyectos claros, compromiso, reservas de memoria } \\
\text { cultural, comunitario, piadoso, laborioso, incansable. }\end{array}$ \\
\hline
\end{tabular}

Cuadro 4.7: Juicio de estima y sanción social: Valores positivos más representativos

\begin{tabular}{|l|l|}
\hline \multicolumn{2}{|c|}{$\begin{array}{l}\text { Juicio de estima y sanción social } \\
\text { (1999-2004) }\end{array}$} \\
\hline \multicolumn{1}{|c|}{ Quién } & \multicolumn{1}{c|}{ Valoración negativa } \\
\hline $\begin{array}{l}\mathbf{1 9 9 9} \\
\text { Proceso de globalización/ } \\
\text { poder económico/ quienes } \\
\text { tienen de poder político, } \\
\text { económico o cualquier tipo de } \\
\text { influencia/ los dirigentes }\end{array}$ & $\begin{array}{l}\text { Vacío, desconfianza, pérdida de compromiso, tibias propuestas, fracasos, odios, } \\
\text { violencia fratricida, tardía, cruelmente, burocracias ineficientes, conflictos, } \\
\text { cenizas tramposas del olvido, superficialidad, coyunturalismo inmediatista } \\
\text { perentoriedad del consumismo, vacío anomia, abandono, fracasos, privilegios, } \\
\text { abusos(1999). }\end{array}$ \\
\hline $\begin{array}{l}\text { El sistema y estructuras } \\
\text { extraños al ser genino del } \\
\text { pueblo }\end{array}$ & $\begin{array}{l}\text { Miedos, inseguridades (el sistema) sombra de la desconfianza, dobles } \\
\text { intenciones, ambición desmedida de poder, dinero, popularidad, } \\
\text { vacíos/vaciedad, sospecha, miedo, poder que acapara y enceguece, } \\
\text { macromanipulaciones, luchas intestinas, insaciabilidad de poder }\end{array}$ \\
\hline
\end{tabular}




\begin{tabular}{|c|c|}
\hline $\begin{array}{l}2001 \\
\text { "algunos"/ quienes utilizan } \\
\text { el poder en su provecho/ los } \\
\text { que dicen escuchar y no } \\
\text { escuchan }\end{array}$ & $\begin{array}{l}\text { Indiferencia, egoismo utilitario, economicista, consenso de intereses, ambigua } \\
\text { realidad, dormirse, odios internos, agonía, mediocridades, sometimiento, } \\
\text { postergación, divisiones,especulación, xenofobia, agitadores de conflictos, } \\
\text { marginación destructiva, violencia, postergan indefinidamente, incertidumbre, } \\
\text { violencia institucionalizada,dañado, privilegios, poderos, su } \\
\text { provecho,escondidos, evaden, lavan las riquezas. }\end{array}$ \\
\hline $\begin{array}{l}2002 \\
\text { Ambiciosos escaladores/ } \\
\text { quienes ya no saben cómo } \\
\text { mentir y contradecirs para } \\
\text { mantener sus privilegios, su } \\
\text { rapacidad y sus cuotas de } \\
\text { ganancia mal habidas/ } \\
\text { "Algunos"/ Zaqueos / }\end{array}$ & $\begin{array}{l}\text { Culpas, trampas, triste, herida, poder, narcotizar, destrucción, sacrificios, } \\
\text { incapacidad, saberes precarios, inexistente humanidad, encerrados, } \\
\text { contradicciones, impotencia, cortedad de miras, sin escrúpulos, soberbia, } \\
\text { amenazas, división, especulación, internismo faccioso, estabilidad consumista y } \\
\text { viajera, lavados que eluden obligaciones, desinformación, confundir, } \\
\text { desestabilizar, caos, ilusión, triste espectáculo, dolor, sorda guerra, inquietud de } \\
\text { acaparar, necios, enanos en el espíritu, mentira, exclusión }\end{array}$ \\
\hline $\begin{array}{l}2003 \\
\text { Los que nos gobiernan }\end{array}$ & $\begin{array}{l}\text { Máscaras, etiquetas, disfraces, la exclusión, sombras del abandono, violencia, } \\
\text { mezquinos intereses de poder y división, ambición, fractura, propuestas } \\
\text { disolutorias, violencia, caos delincuencial, indiferencia, ventajismo del } \\
\text { contrabando, especulación, expoliación, incapacidad, conflictividad, juego } \\
\text { mezquino de las descalificaciones, enfrentamientos, violento, esterilidad de } \\
\text { intelectualidades, ambición, engañar, impunidad del delito, desinformación, } \\
\text { sospecha, desconfianza, perplejidad, desesperanza, desaliento, dictadura, } \\
\text { odios y resentimientos. }\end{array}$ \\
\hline $\begin{array}{l}2004 \\
\text { los que se creen incluidos, } \\
\text { clarividentes, autosuficientes } \\
\text { en la administración de la ley } \\
\text { / elites ilustradas/ izquierdas } \\
\text { ateas/ derechas descreídas/ } \\
\text { los ciegos/ cultores de la } \\
\text { ceguera/ sectores privados/ } \\
\text { cultura mediática }\end{array}$ & $\begin{array}{l}\text { Excluyen, ciegos, inicuos, tácito enfrentamiento, desbarrancar, prejuicios, } \\
\text { facciosidad, cerrazón emocional, cegueras del alma, reclamos histriónicos } \\
\text { inmediatistas, posturas extremas, superficiales, caer, crisis, capricho, } \\
\text { encandilamientos efímeros, falsa ilusión, intolerancia, estancados, } \\
\text { contradiscursos, miedo ciego, despreciar, acusar, ridiculizar, censurar, presionar } \\
\text { y lograr poder, vulgar, mediocridad cultural, difamación, chisme, transgresión, } \\
\text { bastardear, amenaza, despreciar, perversión, goce marketinero de lo morboso, } \\
\text { vacío de identidad, terrible insatisfacción, despojo de lo identitativo, identidad de } \\
\text { cartón, maquillada, importada, adulaciones, justificativos demagógicos, } \\
\text { interpretaciones evasivas, odio, violencia, tirano asesino, desorientación, } \\
\text { inmadurez, cautividad, sangrantes heridas, indiferencia, intolerancia, } \\
\text { individualismo exacerbado, sectarismo, caos, anomia confrontación interna, } \\
\text { falsos modelos, opresión, mentira, ocultamiento, información opaca equívoca. } \\
\text { Confusión, paralizante, perplejidad, réditos de propaganda, descarnada, sin } \\
\text { esperanza, consumismo, exhibicionismo. }\end{array}$ \\
\hline
\end{tabular}

Cuadro 4.8: Juicio de estima y sanción social: Valores negativos más representativos.

Homilías de 2005 a 2010

Sin embargo, en las homilías pronunciadas a partir del año 2005 hay un viraje en el modo de evaluación y el elogio va dirigido tanto al gobierno como al pueblo. A partir de este año, las celebraciones tienen lugar en diócesis del interior del país: 2005 en Santiago del Estero, 2006 en Luján, 2007 en Mendoza, 2008 en Salta, 2009 en Puerto Iguazú y 2010 en Luján. En estas homilías, la etapa de evaluación negativa hacia el gobierno o bien desaparece por completo (como en la homilía del año 2006) o se ve modificada notablemente: son elogiadas tanto la ciudadanía como las autoridades por un celebrante que comulga con su ideología. Como ya lo hemos señalado con anterioridad, este hecho está íntimamente ligado a un cambio importante que 
se da en el contexto histórico que obedece a la decisión del gobierno nacional de elegir para la celebración del Tedeum aquellas diócesis cuyas autoridades estén de acuerdo con su política.

En el fragmento tomado de la misa de Tedeum del año 2005 celebrada en Santiago del Estero vemos claramente el juicio positivo que el hablante hace del gobierno de Néstor Kirchner.

También es digno de destacar que la Nación, por sus autoridades nacionales encabezadas por el Sr. Presidente de la República, eligiera el interior de la República para esta recordación llena de gratitud (H 2005:I 36-38)

No era habitual en las homilías anteriores que el celebrante mencionara la presencia de las autoridades y mucho menos que la agradeciera. Aunque la frase recordación llena de gratitud podría interpretarse por la misa de Tedeum que es de acción de gracias, también, conociendo el contexto se puede leer como un agradecimiento del pueblo santiagueño, que también es protagonista del cambio, al gobierno nacional por las medidas tomadas en su favor. El párrafo siguiente podría avalar esta segunda interpretación:

También nos digna esta presencia de la Nación en este día, en esta etapa de la historia de Santiago. Hoy gozamos del funcionamiento de las instituciones democráticas elegidas por el pueblo soberano y juez. Esto es un fruto madurado por el mismo pueblo santiagueño que se puso de pie para reclamar justicia, cansado de años de arbitrariedad.

Este pueblo reclamó dignidad y entró en diálogo, que ayuda a superar la cultura de la confrontación, de la sospecha, de la dialéctica del amigo-enemigo; diálogo en el que no solo expresó inquietudes sino que también imaginó soluciones, como la necesaria reforma de la Constitución Provincial. Diálogo diversificado, creativo y creciente, que es muestra de una ciudadanía también creciente, que quiere hacerse cargo de la historia, para que nunca más nadie se enseñoree de nuestro pueblo. (H 2005; 161-71)

Como podemos notar en este fragmento, es necesario entender las circunstancias ya que el juicio está evocado de manera más indirecta. Vemos que los indicios de juicio que aparecen en el texto podrían interpretarse como neutrales pero que tienen en la cultura la capacidad de provocar respuestas enjuiciatorias, en este caso, por un contenido social e ideológico compartido por el emisor, la audiencia y el mismo pueblo provincial del cual el locutor es parte. De este modo, las expresiones Hoy gozamos del funcionamiento de las 
instituciones democráticas elegidas por el pueblo soberano y juez y Este pueblo reclamó dignidad y entró en diálogo se leen como indicios de un juicio positivo del pueblo e indirectamente del gobierno nacional frente a lo que se estaba viviendo en Santiago antes de la intervención: la cultura de la confrontación, de la sospecha, de la dialéctica del amigo-enemigo. El juicio negativo hacia quienes gobernaban la provincia en forma dictatorial se explicita mediante la elección de léxico negativo. Este fragmento se remata con una afirmación categórica que termina de definir la postura enjuiciatoria: por un lado, del locutor quien busca, de este modo, acercarse al gobierno nacional que avaló la intervención de la provincia para liberar a ese pueblo de la opresión del gobernador Juárez y su esposa y, por el otro, del pueblo mismo que no quiere ni necesita gobiernos autoritarios:

Santiago no necesita tutores ni tiene dueños que le señalen arbitrariamente el derrotero de la historia, y menos que lo quieran imponer autoritariamente. (H 2005; I 72-73)

Finalmente, el locutor se aproxima a la audiencia en el párrafo final utilizando adjetivos como libre y soberana para mencionar la tarea del gobierno de seguir gestando una nación según la entendía el mismo Juan Domingo Perón quien hablaba de forjar una patria justa, libre y soberana:

En este día tan especial para la Nación, ofrezcamos todos, sin excepción, nuestro compromiso sincero y concreto por seguir gestando una Nación libre y soberana, donde ninguno de sus hijos sea excluido; respetuosa del derecho y con la cordura del diálogo en la resolución de sus conflictos. (H2005;l 75-78)

Podemos observar también el uso del término hijos de una Nación personificada, que anteriormente se había identificado con las autoridades nacionales, y a quien se elogia como respetuosa de los derechos de ese pueblo así como promotora del diálogo para resolver conflictos, ambas cualidades atribuibles a las personas. En estos casos y otros observados, la evaluación de objetos o constructos abstractos como la Nación, la Patria, el sistema democrático, etc. está encuadrada dentro de lo que se denomina el subsistema de Apreciación que en los textos analizados cumple la función de reforzar los valores de Juicio positivo hacia las personas y su conducta, 
aspecto en el que nos hemos concentrado en particular en el presente estudio. Observamos este fenómeno, por ejemplo, en la homilía del año 2007 en la cual el celebrante menciona los comicios que se llevarían a cabo en ese año y relaciona ese hecho con la necesidad de ser fieles a la democracia como garante de la defensa de los derechos de todos.

Estimo, pues, oportuno dar gracias a Dios por estar a las puertas de nuevas elecciones en el ejercicio de nuestra democracia, y que, con los logros y las dificultades que hemos experimentado en estos años, consolidemos la vida sana de la República como un anhelo común.

$Y$ no viene mal recordar a este respecto que recientemente, nuestro actual Sumo Pontífice, instaba a "la fidelidad a la democracia, ya que es la única que puede garantizar la igualdad y los derechos de todos. (H 2007; I 191199)

A nuestro entender, el juicio positivo hacia el gobierno democrático se ve reforzado por los valores positivos de Apreciación atribuidos, en forma general, a una democracia estable o a la consolidación de la vida sana de la República.

En el año 2008, a veinticinco años de la recuperación de la democracia, se vuelve a hacer un llamado a ejercer la fidelidad a la ley y a las instituciones democráticas e, indirectamente, se emite un juicio de valor positivo hacia las autoridades que en definitiva serían quienes respetan la dignidad y los derechos humanos y quienes asumen el bien común para regular la vida.

Su figura (de Facundo de Zuviría) invita a recrear nuestra fidelidad a la ley y a las instituciones de la patria. Es bueno recordarlo en este año del vigésimo quinto aniversario del regreso a la democracia en la Argentina, convencidos que, como nos enseña la Iglesia, "una auténtica democracia no es sólo el resultado de un respeto formal de las reglas, sino que es el fruto de la aceptación convencida de los valores que inspiran los procedimientos democráticos: la dignidad de toda persona humana, el respeto de los derechos del hombre, la asunción del bien común como fin y criterio regulador de la vida política. ( H 2008; I 67-73)

Con el mismo espíritu, en la homilía del año 2009 el celebrante invita a los creyentes a agradecer el regalo de una patria con una democracia estable:

$Y$ por eso es bueno reunirse en la iglesia y en todas las comunidades cristianas y que todos los que creemos en Dios agradezcamos juntos el regalo de una patria con una democracia estable que pretende forjar un bien común que pueda beneficiar a todos los hombres y a todos los sectores de la sociedad. (H 2009;l 60-63) 
Si bien el agradecimiento se dirige en forma global a la democracia, todas estas apreciaciones se relacionan con las personas que permiten la democracia y que se asocian con acciones del hombre. De hecho, el resto de la frase encabezada por el verbo pretende nos indica que son las personas las verdaderas destinatarias del elogio.

Finalmente en 2010, año en que se celebra el bicentenario del primer gobierno patrio, se cita el preámbulo de la Constitución nacional según la cual Dios es fuente de toda razón y justicia así como el proveedor de todo lo bueno que le ha ocurrido al pueblo argentino que además abraza ideales democráticos.

Nuestro Dios, "fuente de toda razón y justicia", como expresa el preámbulo de nuestra constitución, nos ha ayudado paternalmente a caminar, a progresar, a organizarnos, a superar conflictos, a abrazar los ideales democráticos, a recibir en nuestro suelo a todos los "hombres de buena voluntad", a cultivar el espíritu de tolerancia, a promover los amplios y variados caminos de la promoción humana.Por tanto, damos gracias a Dios por la vida de todos nuestros hermanos que habitan este bendito suelo. Riquezas humanas en las diversas razas, desde los aborígenes hasta las diferentes corrientes migratorias. Y gracias también por las riquezas naturales con que hemos sido beneficiados por el Creador en nuestro vasto territorio. (H 2010; | 44-52)

En este último segmento, en el que el locutor exhorta a su audiencia a agradecer a Dios, se encuadra la evaluación positiva hacia el pueblo argentino.

Los cuadros que se reproducen a continuación ilustran las manifestaciones de valores de Juicio en las homilías de este período en las cuales predomina la valoración positiva, aunque también se detecta muy escasa valoración negativa. Solo en la homilía del año 2006 no se ha registrado ningún valor de Juicio. 


\begin{tabular}{|c|c|}
\hline \multicolumn{2}{|r|}{$\begin{array}{l}\text { Juicio de sanción social } \\
\qquad(2005-2010)\end{array}$} \\
\hline Quién & Valoración negativa \\
\hline $\begin{array}{l}2005 \\
\text { tutores / dueños }\end{array}$ & $\begin{array}{l}\text { Arbitrariedad, privilegio, olvido de los más pobres, débiles y sufrientes. } \\
\text { Arbitrariamente, imponer autoritariamente, confrontación, sospecha, dialéctica del amigo- } \\
\text { enemigo }\end{array}$ \\
\hline 2006 & No se registran valores de Juicio \\
\hline 2009 & No se registran valores negativos \\
\hline $\begin{array}{l}2010 \\
\text { nosotros }\end{array}$ & $\begin{array}{l}\text { Súplica de perdón, errores, egoísmos, luchas fratricidas, fragilidad, excluimos, miserias, } \\
\text { mezquindades. }\end{array}$ \\
\hline \multicolumn{2}{|r|}{$\begin{array}{l}\text { Juicio de estima social } \\
(2005-2010)\end{array}$} \\
\hline Quién & Valoración neqativa \\
\hline $\begin{array}{l}2007 \\
\text { los argentinos }\end{array}$ & $\begin{array}{l}\text { Desencuentros, impidieron, frenaron, fidelidad a la democracia. } \\
\text { mera formalidad, perpetúa, diferencias, problemas. }\end{array}$ \\
\hline $\begin{array}{l}2008 \\
\text { No se especifica }\end{array}$ & involutivo, ley de la selva,"viveza criolla" \\
\hline \multicolumn{2}{|r|}{$\begin{array}{l}\text { Juicio de estima y sanción social } \\
\text { (2005-2010) }\end{array}$} \\
\hline Quién & Valoración positiva \\
\hline $\begin{array}{l}2005 \\
\text { Nuestro pueblo /el } \\
\text { mismo pueblo } \\
\text { santiagueño / la } \\
\text { ciudadanía }\end{array}$ & $\begin{array}{l}\text { Gozamos, instituciones democráticas, elegidas, soberano, juez, fruto, de pie, reclamar, } \\
\text { justicia, dignidad, diálogo, superar, ayuda, imaginar, soluciones, diversificado, creativo, } \\
\text { creciente, que es muestra de una también creciente, hacerse cargo, nunca más. }\end{array}$ \\
\hline 2006 & No se han identificado expresiones de juicio. \\
\hline 2007 & $\begin{array}{l}\text { Dar gracias a Dios, por estar a las puertas de nuevas elecciones en el ejercicio de nuestra } \\
\text { democracia, y que, con los logros y las dificultades que hemos experimentado en estos } \\
\text { años, consolidemos la vida sana de la República como un anhelo común. }\end{array}$ \\
\hline $\begin{array}{l}2008 \\
\text { Este pueblo/ } \\
\text { cada salteño y } \\
\text { para el pueblo el } \\
\text { pueblo de Salta, } \\
\text { hombre y mujer del } \\
\text { interior( gaucho) }\end{array}$ & $\begin{array}{l}\text { Madurado, civilidad, servicio, desinterés, proyección, encuentro, Cristo, dignidad, libertad, } \\
\text { libre, digno, profundo amor a la tierra, generoso, cordial, respetuoso, acogedor, valores, } \\
\text { cultura nacional, identidad, diálogo, eficaz, oportunidad, encontrar, escuchar, hablar, } \\
\text { avanzar. }\end{array}$ \\
\hline 2009 & $\begin{array}{l}\text { La democracia/ todos los que creemos en Dios / una patria con una democracia estable } \\
\text { Dar gracias a Dios, construir, mejorar, juntos, regalo, bien común, beneficiar, todos, } \\
\text { futuro,fe, educación, salud, inclusión, trabajar, más, mejor, derechos, ciudadanos, } \\
\text { esperanzada, esperanzadora, oportunidad, construcción. }\end{array}$ \\
\hline $\begin{array}{l}2010 \\
\text { Los padres de la } \\
\text { Patria/ quienes nos } \\
\text { dieron } \\
\text { independencia y } \\
\text { libertad /nuestro } \\
\text { pueblo/ nosotros } \\
\text { pueblos originarios } \\
\text { sucesivas } \\
\text { inmigraciones/ } \\
\text { nuestra nación } \\
\text { /mayores próceres/ } \\
\text { General Manuel } \\
\text { Belgrano /José de } \\
\text { San Martín }\end{array}$ & $\begin{array}{l}\text { Ciudadanos, convencidos, valores, dignifican, persona humana, razón y justicia, ayuda, } \\
\text { paternal, progresar, organizarnos, superar conflictos, abrazar ideales democráticos, } \\
\text { cultivar, espíritu, tolerancia, promoción humana, los valores cristianos, sabiduría, } \\
\text { enriquecieron, cultura, fe, amistad, amor, vida, búsqueda, respeto, dignidad, libertad, la } \\
\text { solidaridad, justicia, educación, familia, amor a la tierra, sensibilidad, ingenio popular, } \\
\text { heroicamente, grande, noble, convicciones cristianas, misericordiosos,perdón. }\end{array}$ \\
\hline
\end{tabular}

Cuadro 4.9: Juicio de estima y sanción social: Valores positivos y negativos más representativos 
Como se subrayó con anterioridad, los valores de juicio son los de mayor incidencia entre todos los valores de actitud codificados en el corpus, razón por la cual nos detuvimos en él. El estudio del subsistema Juicio en los textos que conforman la muestra nos ha permitido analizar cómo los emisores en las homilías de Tedeum evalúan la conducta de los actores sociales en base a un marco determinado de normas sociales y religiosas.

Si bien nos hemos detenido más en los valores de juicio explícitos que se manifiestan a través de adverbios, atributos y epítetos, sustantivos, frases nominales y verbos; también debemos tener en cuenta que el locutor utiliza indicadores de juicio. Con éstos, la descripción aparentemente fáctica de un hecho o situación puede desencadenar una evaluación actitudinal. En esta modalidad, se conduce al interlocutor - ya sea mediante fórmulas de contraexpectativa e intensidad, o con el uso de lenguaje evaluativo perteneciente al sistema de Afecto - hacia la elaboración de un juicio.

Un aspecto a considerar respecto del lenguaje evaluativo presente en la gran mayoría de los textos es, que aunque hay términos que, según nuestro entender son negativos, al encuadrarse en la ideología cristiana surten un efecto contrario. De este modo el sufrimiento, el dolor, la impotencia, valores tan rechazados en nuestra sociedad, son considerados valores de juicio positivo puesto que conducen a la superación personal y fortaleza espiritual: basta mencionar que el sufrimiento de Jesucristo y su muerte en la cruz hicieron posible su resurrección y la salvación, conceptos fundantes de la fe cristiana.

Según lo observado en nuestro análisis de la distribución de los valores positivos y negativos de juicios de estima social y de sanción social en la muestra y de cómo se distribuyen estos valores según los personajes evaluados, estamos en condiciones de concluir que en las homilías que se emitieron entre los años 1976-1980 los juicios son muy escasos y solo se orientan al pueblo respecto de sus sentimientos hacia la patria, o a quienes pertenecen a ideologías reñidas con la fe cristiana. Los valores detectados se encuadran dentro de la categoría de juicios de estima, tanto negativos como positivos, así como de sanción solo negativos. También detectamos casos de 
apreciación hacia cosas, entidades o constructos abstractos que acentúan los valores expresados en los juicios.

El período de transición a la democracia (1987-1996) presenta características del período anterior en el que las evaluaciones son escasas y, si las hay, no se identifica el sujeto evaluado y, por el otro lado, sienta las bases, especialmente en la evaluación negativa con sujetos concretos que se presenta en la última homilía, para las homilías más polémicas del período posterior.

En el período 1999 - 2004 la evaluación se polariza: al pueblo se lo valora con juicios positivos de estima social de tenacidad mientras que a "los otros" se los valora con juicios negativos de sanción social tanto de veracidad como de integridad moral. Sin embargo, a partir del año 2005 hasta el 2010 disminuyen drásticamente los juicios tanto de sanción como de estima negativos que con anterioridad se dirigían a las autoridades y grupos de poder y la gran mayoría de ellos se ubican dentro de los dominios semántico-discursivos de estima y sanción social positiva respecto de la capacidad, tenacidad, veracidad e integridad tanto de las autoridades como del pueblo argentino. Dentro de los valores positivos, predominan en primer lugar la tenacidad y luego la capacidad, no habiéndose encontrado evaluaciones que juzguen la conducta humana según criterios de normalidad. Este hecho se condice con el valor que se otorga al esfuerzo y la modificación de conductas poco deseables en busca de lo sublime en la doctrina cristiana. En cuanto al dominio de la sanción, la búsqueda de la Verdad por sobre todas las cosas propugnada por la misma doctrina, justifica que los valores positivos estén encuadrados en la categoría de la veracidad aunque la integridad moral también sea objeto de juicio.

En el análisis del sistema de Juicio nunca perdimos de vista que éste, según afirman Martin y White 2005, está constreñido por la situación cultural e ideológica particular en la que opera. La forma en que los locutores evalúan en su discurso la capacidad, tenacidad, veracidad e integridad $u$ otro rasgo de la conducta de las personas está siempre determinada por la cultura y la fe católica con la que se comulga. Aunque siempre cabe la posibilidad de que una misma conducta sea valorada de forma diferente, queda muy poco espacio para esa alternativa en nuestra cultura de fuerte raigambre cristiana. 


\section{CONCLUSIONES}

En este trabajo hemos presentado un análisis desde el punto de vista lingüístico de cómo se construye una realidad particular en el discurso de homilías de Tedeum. A continuación, me refiero a los resultados más relevantes que manifiestan de qué modo mediante la elección de un género y el uso particular del lenguaje, los autores codifican determinadas posturas ideológicas que crean una realidad determinada por el entorno que le proporciona la institución y el momento histórico en el que se emite.

\section{La ideología y la elección de género}

Aún cuando hemos analizado con bastante detalle los aspectos del género de los textos que componen el corpus, se hace necesario enfatizar el hecho de que bajo la elección de un género y la construcción de un texto coherente en términos de registro, existen posiciones e intereses a los que el discurso debe servir. Si bien el registro y el género constituyen dos perspectivas importantes para el texto en contexto, también fue necesaria una tercera dimensión 'crítica' que enfoca consideraciones ideológicas. Los autores de los textos analizados presentan a los asistentes al Tedeum una visión particular de la realidad, y una visión especial de los valores propiciados por la institución con la que comulgan.

Hemos observado en todos los textos que el posicionamiento del hablante ante la audiencia cumple funciones ideológicas poderosas. Se construye desde el púlpito una postura hegemónica respecto de quién ejerce el poder político, mediante elecciones temáticas de índole moral o ética inapelables, puesto que los valores cristianos se respetan como válidos dentro de la sociedad en general y no solo de la feligresía creyente.

Al comenzar nuestro trabajo, nos planteamos una serie de hipótesis que guiaron este estudio y que se comentarán a continuación: 
Hipótesis (i):

Las homilías de Tedeum de 25 de mayo constituyen un género discursivo que puede analizarse desde un punto de vista sistémico-funcional.

La primera hipótesis formulada se ha confirmado, puesto que hemos observado $y$ analizado en la totalidad de los textos que componen el corpus, que los mismos tienen una misma función global que se podría definir desde su propósito comunicativo, como un género que apunta a persuadir y a exhortar tanto a la audiencia presente en la celebración así como al pueblo argentino, a que actúe en concordancia con los preceptos emanados de la doctrina de la Iglesia. Se trata de un género claramente religioso en el que se utilizan recursos del discurso político, especialmente en los fragmentos evaluativos, con el propósito de llegar a una audiencia presencial que, en su mayoría, pertenece a ese ámbito.

Asimismo, la Iglesia utiliza este género para dar a conocer su postura frente a acontecimientos del ámbito político y social y, utilizando estrategias más cercanas al discurso político, hacer oír su elogio o condena hacia las autoridades según éstas actúen o no de acuerdo a los valores propugnados por la fe cristiana. De hecho, Monseñor Taussig afirma que "el Te Deum como celebración de la Palabra siempre es la ocasión profética de proyectar el Magisterio de la Iglesia al orden político y social, conforme a las necesidades que plantean las circunstancias." ${ }^{32}$

En cuanto al abordaje teórico del análisis, estamos en condiciones de confirmar que la lingüística Sistémico- Funcional resultó sumamente adecuada para el presente estudio puesto que presenta una teoría sólida sobre el contexto. Así pues, al abordar los textos para determinar su función global, siempre tuvimos en cuenta su contexto tanto de situación como de cultura así como también la ideología que les sirvió de sustento.

\footnotetext{
32 Intervención en la Inauguración de la XXXV SEMANA TOMISTA -Congreso Internacional, sobre el tema PATRIA Y BIEN COMÚN - Reflexiones en el Bicentenario 2010-2016, Buenos Aires, 13 de septiembre de 2010.
} 
Con el propósito de ver la conformación de los textos como exponentes de un género determinado, reproducimos a continuación una primera grilla en la que se detalla la presencia o ausencia de las etapas detectadas en la totalidad de los textos (ver cuadro 5.1 en página siguiente). La etapa de evaluación se encuentra, a su vez, subdividida según la misma se centre en la emisión de juicios de valoración positivos o negativos. Como se puede observar, la etapa de motivación solo está ausente en la homilía del año 2002. El resto de las etapas están presentes en todos los textos con la excepción de la homilía de 2006 en la que no se detectaron pasajes evaluativos ni de Juicio ni de Apreciación.

En el segundo cuadro, se ilustra la cantidad total de renglones que ocupa cada uno de los textos y cada una de las etapas y se muestran los porcentajes de líneas correspondientes a cada etapa respecto de la totalidad de líneas del texto. El propósito perseguido fue visualizar cuantitativamente la relevancia que se le quiso dar a cada etapa y cómo este hecho se traduce en un texto de corte más expositivo, informativo, persuasivo o argumentativo. Asimismo, a partir de estos datos, se hizo una interpretación de los aspectos contextuales que determinaron las elecciones por parte del productor del texto. Vemos aquí la dimensión del discurso como práctica social en la que se da cuenta de que todo evento discursivo está inserto en un conjunto de situaciones, instituciones y macro-contextos que condicionan fuertemente los usos del lenguaje.

Si bien las etapas identificadas son consideradas obligatorias en el presente estudio, existen dos casos, ya mencionados con anterioridad, en los que falta alguna de ellas (la motivación en el 2002 y la evaluación en el 2006) pero estos textos no dejan de ser por eso exponentes del género analizado, a lo sumo podrían considerarse textos incompletos. En otros casos, se han detectado pasajes que no obedecen a las características distintivas de ninguna de las etapas identificadas. 


\begin{tabular}{|c|c|c|c|c|c|c|}
\hline \multirow[t]{2}{*}{ No } & \multirow[t]{2}{*}{ Homilía } & \multirow{2}{*}{$\begin{array}{l}\text { MOTIVACIÓN } \\
\text { Celebración de Tedeum. } \\
\text { Conmemoración de } \\
\text { Fecha patria. }\end{array}$} & \multirow{2}{*}{$\begin{array}{l}\text { FUNDAMENTACIÓN } \\
\text { IDEOLÓGICA }\end{array}$} & \multicolumn{2}{|c|}{ EVALUACIÓN } & \multirow{2}{*}{$\begin{array}{l}\text { CONCLUSIóN } \\
\text { exhortación al cambio. } \\
\text { Conducta a seguir. }\end{array}$} \\
\hline & & & & $\begin{array}{l}\text { Valoración } \\
\text { negativa }\end{array}$ & $\begin{array}{c}\text { Valoración } \\
\text { positiva }\end{array}$ & \\
\hline 1 & $25 / 5 / 76$ & $\mathbf{X}$ & $\mathbf{X}$ & $\mathbf{X}$ & - & $\mathbf{X}$ \\
\hline 2 & $25 / 5 / 79$ & $\mathbf{X}$ & $\mathbf{X}$ & $\mathbf{X}$ & - & $\mathbf{X}$ \\
\hline 3 & $5 / 5 / 80$ & $\mathbf{X}$ & $\mathbf{X}$ & $\mathbf{X}$ & $\mathbf{X}$ & $\mathbf{X}$ \\
\hline 4 & $25 / 5 / 87$ & $\mathbf{X}$ & $\mathbf{X}$ & $\mathbf{X}$ & - & $\mathbf{X}$ \\
\hline 5 & $25 / 5 / 93$ & $\mathbf{X}$ & $\mathbf{X}$ & $\mathbf{X}$ & $\mathbf{X}$ & $\mathbf{X}$ \\
\hline 6 & $25 / 5 / 96$ & $\mathbf{X}$ & $\mathbf{X}$ & $\mathbf{X}$ & - & $\mathbf{X}$ \\
\hline 7 & $25 / 5 / 99$ & $\mathbf{X}$ & $\mathbf{X}$ & $\mathbf{X}$ & $\mathbf{X}$ & $\mathbf{X}$ \\
\hline 8 & $25 / 5 / 00$ & $\mathbf{X}$ & $\mathbf{X}$ & $\mathbf{X}$ & $\mathbf{X}$ & $\mathbf{X}$ \\
\hline 9 & $25 / 5 / 01$ & $\mathbf{X}$ & $\mathbf{X}$ & $\mathbf{X}$ & $\mathbf{X}$ & $\mathbf{X}$ \\
\hline 10 & $25 / 5 / 02$ & - & $\mathbf{X}$ & $\mathbf{X}$ & $\mathbf{X}$ & $\mathbf{X}$ \\
\hline 11 & $25 / 5 / 03$ & $\mathbf{X}$ & $\mathbf{X}$ & $\mathbf{X}$ & $\mathbf{X}$ & $\mathbf{X}$ \\
\hline 12 & $25 / 5 / 04$ & $\mathbf{X}$ & $\mathbf{X}$ & $\mathbf{X}$ & $\mathbf{X}$ & $\mathbf{X}$ \\
\hline 13 & $25 / 5 / 05$ & $\mathbf{X}$ & $\mathbf{X}$ & $\mathbf{X}$ & $\mathbf{X}$ & $\mathbf{X}$ \\
\hline 14 & $25 / 5 / 06$ & $\mathbf{X}$ & $\mathbf{X}$ & - & - & $\mathbf{X}$ \\
\hline 15 & $25 / 5 / 07$ & $\mathbf{X}$ & $\mathbf{X}$ & $\mathbf{X}$ & $\mathbf{X}$ & $\mathbf{X}$ \\
\hline 16 & $25 / 5 / 08$ & $\mathbf{X}$ & $\mathbf{X}$ & - & $\mathbf{X}$ & $\mathbf{X}$ \\
\hline 17 & $25 / 5 / 09$ & $\mathbf{X}$ & $\mathbf{X}$ & - & $\mathbf{X}$ & $\mathbf{X}$ \\
\hline 18 & $25 / 5 / 10$ & $\mathbf{X}$ & $\mathbf{X}$ & $\mathbf{X}$ & $\mathbf{X}$ & $\mathbf{X}$ \\
\hline
\end{tabular}

Cuadro 5.1: Etapas obligatorias y no obligatorias presentes en las homilías 


\begin{tabular}{|c|c|c|c|c|c|c|c|c|c|c|}
\hline \multirow[t]{2}{*}{ No } & \multirow[t]{2}{*}{ Homilía } & \multirow[t]{2}{*}{$\begin{array}{l}N^{\circ} \text { de } \\
\text { líneas }\end{array}$} & \multicolumn{2}{|c|}{ MOTIVACIÓN } & \multicolumn{2}{|c|}{$\begin{array}{l}\text { FUNDAMENTACIÓN } \\
\text { IDEOLÓGICA }\end{array}$} & \multicolumn{2}{|c|}{ EVALUACIÓN } & \multicolumn{2}{|c|}{ CONCLUSIÓN } \\
\hline & & & Líneas & $\begin{array}{l}\text { Porcentaje } \\
(\%)\end{array}$ & Líneas & $\begin{array}{l}\text { Porcentaje } \\
\quad(\%)\end{array}$ & Lineas & $\begin{array}{c}\text { Porcentaje } \\
(\%)\end{array}$ & Lineas & $\begin{array}{c}\text { Porcentaje } \\
(\%)\end{array}$ \\
\hline 1 & $25 / 5 / 76$ & 60 & 8 & 13,33 & 31 & 51,66 & 3 & 5 & 18 & 30 \\
\hline 2 & $25 / 5 / 79$ & 124 & 12 & 9,67 & 78 & 62,9 & $\mathbf{1 0}$ & 8,06 & 24 & 19,35 \\
\hline 3 & $25 / 5 / 80$ & 96 & 11 & 11,45 & 65 & 67,08 & 11 & 11,45 & 9 & 9,37 \\
\hline 4 & $25 / 5 / 87$ & 69 & 12 & 17,39 & 38 & 54,06 & 6 & 8,5 & 13 & 18,84 \\
\hline 5 & $25 / 5 / 93$ & 125 & 10 & 8 & 71 & 56,8 & 27 & 21,6 & 17 & 13,6 \\
\hline 6 & $25 / 5 / 96$ & 108 & 3 & 2,77 & 47 & 43,51 & 41 & 37,96 & 17 & 15,74 \\
\hline 7 & $25 / 5 / 99$ & 160 & 14 & 8,75 & 23 & 14,37 & 59 & 36,87 & 64 & 40 \\
\hline 8 & $25 / 5 / 00$ & 119 & 7 & 5,88 & 30 & 25,21 & 20 & 16,8 & 62 & 52,10 \\
\hline 9 & $25 / 5 / 01$ & 163 & 3 & 1,84 & 34 & 20,85 & 82 & 50,30 & 44 & 26,99 \\
\hline 10 & $25 / 5 / 02$ & 158 & ------- & - & 47 & 29,74 & 64 & 40,50 & 47 & 29,74 \\
\hline 11 & $25 / 5 / 03$ & 177 & 10 & 5,64 & 52 & 29,37 & 70 & 39,54 & 45 & 25,42 \\
\hline 12 & $25 / 5 / 04$ & 237 & 8 & 3,37 & 72 & 30,37 & 135 & 56,96 & 22 & 9,28 \\
\hline $13^{*}$ & $25 / 5 / 05$ & 85 & 4 & 4,70 & 26 & 30,58 & 14 & 16,47 & 27 & 31,76 \\
\hline 14 & $25 / 5 / 06$ & 88 & 14 & 15,9 & 62 & 71,45 & - & - & 12 & 13,63 \\
\hline 15 & $25 / 5 / 07$ & 239 & 28 & 11,71 & 176 & 73,64 & 8 & 3,34 & 27 & 11,29 \\
\hline $16^{*}$ & $25 / 5 / 08$ & 121 & 4 & $\mathbf{3 , 3}$ & 51 & 42,14 & 18 & 14,87 & 37 & 30,57 \\
\hline 17 & $25 / 5 / 09$ & 94 & 27 & 28,72 & 35 & 37,23 & 14 & 14,89 & 18 & 19,14 \\
\hline 18 & $25 / 5 / 10$ & 145 & 13 & 8,96 & 77 & 53,1 & 33 & 22,75 & 22 & 15,17 \\
\hline
\end{tabular}

Cuadro 5. 2: Etapas constitutivas, su longitud y porcentajes.

*Observaciones: En los textos correspondientes a las homilías de los años 2005 y 2008 hay fragmentos (14 líneas en el primero y 11 en el segundo) que no pertenecen a ninguna de las etapas identificad 
Hipótesis (ii):

El discurso está construido mediante la inclusión de voces por parte del emisor quien pone de manifiesto qué tipo de relación mantiene con ellas, y cómo desea que esta relación sea percibida por la audiencia.

La segunda hipótesis formulada también se ha confirmado, ya que cuando el emisor decide traer a su discurso voces pasadas no efectúa una simple reproducción de un discurso, sino una reconstrucción más o menos fiel, donde siempre están su voz y su postura ideológica que se manifiestan tanto en las transformaciones efectuadas a las palabras originales como en el verbo anunciador de la cita elegido. En efecto, en la mayoría de las ocasiones en las que el emisor incorpora otras voces, pone de manifiesto el tipo de relación que él establece con esos enunciados anteriores dentro de la misma esfera, vale decir, con quienes hayan adoptado anteriormente una postura respecto del tema tratado en el texto. Esta relación que establece el emisor actual con los anteriores es, en gran medida, de respaldo puesto que se refiere explícitamente a ellos como fuente de su discurso, o simplemente, para dar a conocer su influencia. Las proposiciones referidas son introducidas, en su mayoría, con verbos anunciadores de cita positivos que apuntan a incorporar las palabras y puntos de vista de voces externas que contribuyen a la postura asumida por el locutor y, de este modo, la dotan de aún mayor credibilidad. En el caso particular que se observa con las Sagradas Escrituras, observamos que la extravocalización, o sea la apelación a la palabra tomada del Evangelio como la Palabra de Dios, es más fuerte que una afirmación categórica. La voz genera una situación de contracción dialógica en cuanto a la relación emisor audiencia. La voz incorporada proporciona mayor autoridad a la voz del locutor, quien, desde un posicionamiento hegemónico, cierra el espacio dialógico con su interlocutor.

También nos hemos detenido en las señales que los emisores proporcionan respecto de cómo esperan que sus receptores reaccionen frente a su discurso. Con esta anticipación, los emisores construyen y negocian la solidaridad de sus 
receptores modelo. Cabe señalar, que la relación de solidaridad que se construye en el discurso no significa, sin embargo, la búsqueda de la total conformidad de la audiencia sino que, en este contexto, significa tolerancia hacia la diversidad de voces y puntos de vista, tanto reales como potenciales, que se activan en el texto.

Hipótesis (iii):

El locutor asume un compromiso respecto de su discurso y, a la vez, toma un posicionamiento frente a la audiencia que construye desde el consenso $o$ el disenso.

Con respecto a la tercera hipótesis, hemos observado que el emisor efectivamente asume un compromiso respecto de su discurso tomando un posicionamiento frente a la audiencia. Nos valimos de la Teoría de la Valoración que se ocupa en particular de la expresión lingüística de la actitud, así como del conjunto de recursos que, en forma explícita, posicionan de manera interpersonal las "propuestas" y proposiciones textuales (Halliday, 1994). Pudimos observar que desde la perspectiva dialógica de Bajtín, incorporada a la Teoría de la Valoración, las estrategias evaluativas pueden entenderse como orientaciones más o menos dialógicas que los autores adoptan para construir cierta solidaridad ideológica con sus interlocutores en relación a lo expuesto en el discurso. El posicionamiento del locutor de las homilías de Tedeum consiste en contraer el espacio dialógico respecto de su audiencia al evaluar a las personas, sus conductas y acontecimientos. La mayoría de las evaluaciones se presentan de manera casi absoluta, sin reconocer la posibilidad de un debate entre voces y puntos de vista diferentes en el espacio dialógico. También estamos en condiciones de afirmar que el emisor en las homilías más polémicas asume el rol de representante de una voz social opositora a la de la clase dirigente. Nuestro análisis se basó en los recursos utilizados por el emisor quien, por un lado, evalúa negativamente al otro discursivo y, por el otro, asume como propia la voz del pueblo que obedece a la moral cristiana. Este hecho marca una característica propia del género que nos ocupa puesto que, como ya expusimos en otras oportunidades, 
su función global es la de exhortar e invitar al cambio partiendo de una situación que se plantea como poco deseable y reñida con los dictados de la fe cristiana.

En algunos textos, el locutor busca desafiar a la audiencia posicionándose él mismo en lo que considera que "debería ser" frente a lo que la audiencia "es". En otros, el emisor construye y negocia la solidaridad de sus receptores ideales cuando deja explícita su postura frente a determinado tema e invita a la audiencia a respaldarla y compartirla. Sin embargo, en las homilías más polémicas la solidaridad no se construye con la audiencia real, que queda ubicada en posición antagónica, alineada con los "otros" sino con un receptor ideal. La postura ideológica institucional planteada es inamovible, no admite voces disidentes, aunque se las mencione para presentarlas como el modelo que no se debería imitar. Hemos observado que, con el uso frecuente de la negación como de la contra-expectativa el locutor se anticipa a cualquier duda o resistencia que pueda surgir por parte de la audiencia y de este modo, pone de manifiesto la validez de la postura asumida.

Hipótesis (iv):

El sistema de Juicio está constreñido por la situación particular en la que opera. El modo en que los emisores evalúan en su discurso la conducta humana, está determinado por la situación cultural e ideológica en la que se emiten los textos estudiados.

La cuarta hipótesis también se habría confirmado. Con referencia a los elementos evaluativos, nuestro interés se concentró principalmente en los valores de Juicio, puesto que son los de mayor incidencia entre todos los valores de actitud codificados en el corpus. El estudio del subsistema de Juicio en los textos que conforman la muestra nos ha permitido analizar cómo los emisores en las homilías de Tedeum evalúan la conducta de los actores sociales en base a un marco determinado de normas sociales y religiosas. Estos aspectos son los que dan cuenta del posicionamiento que el emisor adopta respecto de los actores y eventos evaluados. 
La comparación de los resultados obtenidos en el estudio puso en evidencia las diferencias que se detectaron en las homilías pertenecientes a los distintos períodos en los que se agruparon. Según lo observado, podemos concluir que en las homilías pertenecientes al primer período (1976-1980), al segundo (1987-1996) así como en aquellas emitidas entre los años 2005-2010, los juicios son más escasos respecto de las homilías más polémicas pertenecientes al período 1999-2004. Este hecho es coincidente con la cantidad de líneas destinadas a la etapa de evaluación (ver cuadro 5.2) que en este período disminuyen drásticamente, hecho que se revierte en el período identificado como el más polémico comprendido entre los años 1999 - 2004.

En cuanto a los sujetos evaluados en el primer período, los valores de juicio están orientados mayoritariamente al pueblo respecto de sus sentimientos hacia la patria, mientras que en el segundo período, a medida que la etapa de evaluación va cobrando más relevancia - de $8,5 \%$ a $37,96 \%$ - el sujeto evaluado también se va identificando y, recién en la última homilía de este período, se concretan los sujetos evaluados en forma negativa ( partidos políticos, clase empresaria, el periodismo, asociaciones gremiales, culturales etc.). Asimismo, hemos observado que en este período (1987-1996) el locutor recurre a la evaluación de apreciación hacia cosas, entidades o constructos abstractos con la intención de reforzar los valores expresados en los juicios hacia las personas. Pudimos también observar que el período más polémico que comprende las homilías de los años 1999 al 2004, se caracteriza por una evaluación marcadamente polarizada entre los juicios positivos tanto de estima como de sanción social orientados al pueblo y los juicios negativos de estima y de sanción para evaluar a los "otros". En cuanto al período final ( 2005-2010), notamos que los juicios tanto de sanción como de estima negativos que en el período anterior se dirigían a las autoridades y grupos de poder, ahora se ubican dentro de los dominios de estima y sanción social positiva respecto de la capacidad, tenacidad, veracidad e integridad tanto de las autoridades como del pueblo argentino. De ello se deduce que el emisor, en esta ocasión, concede mayor importancia a la evaluación de la conducta de los personajes en base a principios éticos codificados en leyes y normas, puesto que hay un constante elogio de las instituciones, de la fidelidad a la democracia y lo bueno 
de su permanencia en el tiempo. Por el contrario, los aspectos sociales relativos a las fortalezas o debilidades en lo que concierne a la gestión en sí tienen menos relevancia.

Además de los valores de Juicio explícitos en el corpus, hemos detectado indicadores de Juicio, mediante los cuales la descripción aparentemente fáctica de un hecho o situación puede desencadenar una evaluación actitudinal. De este modo, el emisor, mediante el uso de fórmulas de contra-expectativa e intensidad así como de lenguaje evaluativo perteneciente al sistema de afecto, conduce al interlocutor hacia la elaboración de un juicio.

Este trabajo constituye un abordaje al estudio de género de las homilías de Tedeum así como de sus aspectos evaluativos. Se fueron señalando en distintos apartados de esta tesis, características distintivas no solo del género sino también de los distintos contextos en los que los textos en estudio fueron emitidos. Se hizo asimismo una detallada observación de los recursos utilizados para valorar la experiencia social. En este sentido, el análisis apuntó a la descripción y explicación de los sistemas de opciones semánticas que ofrece el lenguaje para evaluar, adoptar posiciones, construir personas textuales o identidades discursivas, asumir roles, negociar relaciones, y considerar como naturales las posturas intersubjetivas adoptadas. Queda, sin embargo, abierto el camino para profundizar el estudio del género así como de posicionamiento y evaluación en otras homilías o exponentes de otros discursos religiosos. Hay, también, aspectos de la teoría de la Valoración que quedaron por explorar ya sea en el mismo corpus o en otros textos del mismo género que se emitan en contextos históricos diferentes. 


\section{BIBLIOGRAFÍA}

AA.VV. (1994). El arte de la homilía. Barcelona: Centre de Pastoral Liturgica.

Acebal, M (2007): "La paráfrasis del texto bíblico en la homilía católica. Aportes al género y variaciones de su realización", en Actas del Congreso Internacional: Transformaciones culturales Debates de la teoría, la crítica y la lingüística. Buenos Aires: Edición digital.

Acebal, M (2010). "Las estrategias de adecuación en las homilías católilcas. Aportes de la lingüística sistémico funcional al análisis de las estrategias discursivas", en El discurso en español y portugués. Estudios desde una perspectiva sitémico-funcional. Fernández, M. D Ghio, E (compiladoras). Santa Fe, Argentina: Universidad Nacional del Litoral.

Aldazábal, J (2006). El ministerio de la Homilía. Centro de Pastoral Litúrgica. Disponible en:http://books.google.com.ar/books?id=iChX6ThESYC\&pg=PA159\&dq=la+homilia +como $+g \% C 3 \% A 9 n e r o+$ discursivo $\& \mid r=\&$ source $=$ gbs toc $\mathrm{r} \& \mathrm{cad}=4 \# \mathrm{~V}=$ onepage $\& \mathrm{q}=\& \mathrm{f}=$ false. [Consulta: 30 octubre 2008]

Arnoux, E (2003): "La reformulación interdiscursiva en el Análisis del discurso", en Actas del Congreso "Análisis del discurso y enseñanza de la lengua". Lima: Universidad Ricardo Palma.

Arnoux, E y M.I. Blanco (2002): "Otras formas de persuasión. La interpretación de textos bíblicos", en Actas del Congreso Internacional "La argumentación", Buenos Aires: Universidad de Buenos Aires, Instituto de Lingüística.

Arnoux, E y M.I. Blanco (2004) "Polifonía institucional y eficacia persusiva en los discursos oficiales de la Iglesia Católica Argentina frente a la crisis", en Homenaje a Oswald Ducrot. Buenos Aires: Eudeba.

Bajtín, M. M. (2005 [1982, 1979]). "El problema de los géneros discursivos", en Estética de la creación verbal. 248-293. Buenos Aires: Siglo XXI Editores

Barros, D. L. P. (2003). "Dialogismo, polifonia e enunciacăo", en D. L. P de Barros y J. L. Fiorin (Orgs.), Dialogismo, polifonia, intertextualidade: em torno de Bakhtin 1-9. (2a. ed., 1a ed., 1994). Săo Paulo: Editora da Universidade de Săo Paulo.

Bhatia, V. (1993). Analysing genre-language use in professional settings. London: Longman.

Bhatia, V. (2004). Worlds of Written Discourse. A Genre-based view. London: Continuum.

Bonnin, J.E.(2006) "Géneros y tradiciones discursivas en un caso de intersección entre el discurso político y el religioso", en Actas del Congreso 
Internacional: Transformaciones culturales: Debates de la teoría, la crítica y la lingüística. Buenos Aires: Edición digital.

Bonnin, J. E (2009) "Los usos políticos de la homilía y los límites del dialogismo religioso", en Granato, Luisa y María L. Móccero Actas del IV Coloquio Argentino de la IADA (International Association for Dialogue Analysis). 83-92. La Plata. Universidad Nacional de La Plata. Edición digital.

Bonnin, J. E (2010) "Los géneros discursivos en la estrategia del episcopado católico argentino: Aspectos políticos del discurso religioso entre el autoritarismo y la democracia (1965-1990)". Revista Signos [online]. 2010, vol.43, n.72: 9-30. [consulta: 5- 2- 2011]

Bunge, Mario. (1995ª) Sistemas sociales y filosofía. Buenos Aires: Sudamericana.

Caldas-Coulthard, C.R. ( 1994) "On Reporting Reporting: The Representation of Speech in Factual and Fictional Narratives", in M. Coulthard (ed.) Advances in Written Text Analysis. 295-308. London: Routledge.

Calsamiglia, H., y A. Tuson (1999). Las cosas del decir: Manual de análisis del discurso. Barcelona: Ariel.

Charaudeau, P. 2004. "La problemática de los géneros. De la situación a la construcción textual". Revista Signos. Estudios de Lingüística, 37 (56): 23 -39.

Christie, F., \& Martin, J.K. (Eds.). (1997). Genre and Institutions: social processes in the workplace and school. London: Pinter.

Ciapuscio, G. (1994) Tipos textuales. Buenos Aires: Eudeba.

Ciapuscio, G. (2000) "Hacia una tipología del discurso especializado". Discurso y Sociedad, 2 ( 2): 39-71.

Ciapuscio, G. (2005). "La noción de género en la Lingüística Sistémico Funcional y en la Lingüística Textual". Revista Signos, 38 (57). 31-48. [ Consulta: 12-3- 2010]

Di Stefano, R. y L. Zanatta (2000) Historia de la Iglesia Argentina: Desde la Conquista hasta fines del siglo XX. Buenos Aires: Grijalbo Mondadori

Ducrot, O. (1986) El decir y lo dicho. Buenos Aires: Paidós.

Ducrot, O. (1990) Polifonía y argumentación. Cali: Universidad del Valle.

Durkheim, É (2001) Formas elementales de la vida religiosa. México: Ed.Coyoacán.

Eggins, S. (2004 [ 1994]). An Introduction to Systemic Functional Linguistics. London: Pinter. 
Eggins, S., \& Slade, D. (1997). Analysing Casual Conversation. London: Cassell.

Eggins, S y J.R. Martin (1997) "El contexto como género: una perspectiva lingüística funcional". Revista Signos [online]. 2003, vol.36, n 54. 185-205. [consulta18-12-10-].

Eggins, S. y J. R. Martin. (1997) "Géneros y registros del discurso", en Teun A. van Dijk. (Ed) El discurso como estructura y proceso. Volumen I. 335-371. Barcelona: Gedisa.

Eggins S. y J.R. Martin (2003) "El contexto como género: Una perspectiva lingüístico-funcional”. Revista Signos, 36(54). 185-205. [consulta: 5- 12- 2009]

Fairclough, N. (1992). Discourse and Social Change. Cambridge: Polity Press.

Fairclough, N. (1995). Media Discourse. London: Edward Arnold.

Fairclough, N. (1998). "Political discourse in the media: An analytic framework.". en A. Bell y P. Garrett, Approaches to Media Discourse. 142-162. Oxford y Malden: Blackwell Publishers.

Fairclough, N. (2000a) "Language and Neo-Liberalism". Discourse \& Society, 11(2): 147-148.

Fairclough, N. (2003a) Analysing Discourse. Textual Analysis for Social Research. London: Routledge.

Firth, J. R. (1957a) "Ethnographic analysis and language with reference to Malinowski's views." En R. W. Firth (Ed.), Man and Culture: an evaluation of the work of Bronislaw Malinowski. 137-167. London.: Longman.

Gee, J.P. (2011). How to do Discourse Analysis. A Toolkit. New York and London: Routledge.

Gili Gaya, S (1980) Curso superior de sintaxis española. Marcadores conversacionales de modalidad epistémica que se usan con enunciados declarativos. Barcelona: Vox.

Goffman, E. (1963) Behaviour in Public Places. Notes on the Social Organization of Gathering. Glencoe: Macmillan.

Goffman, E. (1967) Interaction Ritual: Essay on Face-to Face Bahaviour. New York: Doubleday Anchor.

Gómez Torrego, L. (1997) Gramática didáctica del español. Madrid: Ed. SM

Grimes, Joseph E. (1975). The thread of discourse. The Hague: Mouton 
Halliday, M. A. K. (1978). Language as a Social Semiotic: the social interpretation of language and meaning. London: Edward Arnold.

Halliday, M. A. K. (1985a). An Introduction to Functional Grammar. London: Edward Arnold.

Halliday, M. A. K. (1985b). Spoken and Written Language. Geelong, Vic.: Deakin University Press. [reeditado por Oxford University Press, 1989]. [consulta: 15- 12- 2010]

Halliday, M. A. K. (2004). An Introduction to Functional Grammar (3a ed. revisada por C. Matthiessen). London: Arnold.

Halliday, M. A. K. y Hasan, R. (1976). Cohesion in English. London: Longman.

Halliday, M. A. K., \& Hasan, R. (1989 [1985, 1980]). Language, Context and Text: Aspects of Language in a Social-semiotic Perspective. Oxford: Oxford University Press.

Halliday, M. A. K., \& Martin, J.R. (1993). Writing Science: Literacy and Discursive Power. London: Falmer Press.

Hasan, R. (1984/ 1996:54) "The Nursery tale as a genre" Nottingham Linguistic Circular 13. 71-102.

Heinemann, W. (2000) Textsorten. Zur Diskussion um Basisklassen des Kommunizierens. Rückschau und Ausblick [Clases textuales. Para la discusión sobre las clases de base del comunicar. Retrospectiva y panorama], en K. Adamzik (Ed.), Textsorten. Reflexionen und Analysen [Clases de textos. Reflexiones y análisis] Stauffenburg, Tübingen. (Traducción de Guiomar Ciapuscio, mimeo, UBA, s/f.)

Heinemann, W. y D. Viehwegger (1991) Textlinguistik: eine Einführung [Lingüística del texto: una introducción], Max Niemeyer, Tübingen. Citado y traducido fragmentariamente en Ciapuscio 1994.

Hernández Sampieri, R (1991) Metodología de la investigación. México: Mc Graw Hill.

Hoey, M. (1983). On the Surface of Discourse. London: George Allen and Unwin.

Hymes, D. (1967). "Models of the interaction of language and social setting". Journal of Social Issues 23, 8-28. [consulta: 4- 9- 2009]

Kaplan, N. (2004): "Nuevos desarrollos en el estudio de la evaluación en el lenguaje: la teoría de la valoración". Boletín de Lingüística. Vol.22, jul.-dic.52-78 
Kaplan, N (2007) "La teoría de la valoración: un desarrollo de los estudios sobre la evaluación en el lenguaje", en Bolívar, A. (compiladora) Análisis del discurso ¿Por qué y para qué?63-86. Caracas: El Nacional

Labov, W. (1972) Language in the Inner City: Studies in the Black English Vernacular. Philadelphia: University of Pennsylvania Press.

Lakoff, G. (1972). "Hedges: A study in meaning criteria and the logic of fuzzy concepts", en J.N. Levi y G. C. Phares (Eds.), Papers from 8th Regional Meeting of the Chicago Linguistic Society. 183-228. Chicago: University of Chicago.

Maldonado, L (1993) La homilía. Predicación. Liturgia. Comunidad. Buenos Aires: Ed. Paulinas.

Mallimaci, F. (1992). "El catolicismo argentino: Del liberalismo integral a la hegemonía militar", en AAVV, 500 Años de Cristianismo en la Argentina. Pgs. 197-365. Buenos Aires: CEHILA-Nueva Tierra.

Malinowski, B. (1923). "The problem of meaning in primitive languages". en C. K. Ogden \& I.A.Richards (Eds.), The Meaning of Meaning. 296-336. New York: Harcourt Brace y World.

Malinowski, B. (1935). Coral Gradens and their Magic. (Vol. 2). London: Allen and Unwin.

Martin, J. R. (1992). English Text: System and Structure. Amsterdam/ Philadelphia: John Benjamins. [consulta: 5- 9- 2009]

Martin, J. R. (1995a). "Interpersonal meaning, persuasion, and public discourse: Packing semiotic punch". Australian Journal of Linguistics, 15, 3367.

Martin, J. R. (1995b). "Reading positions/positioning readers: Judgement in English." Prospect: a Journal of Australian TESOL, 10(2), 27-37.

Martin, J. R. (1997). "Analysing genre: Functional parameters", en F. Christie, y J. R. Martin (Eds.), Genres and institutions: Social processes in the workplace and school . 3-39. London: Cassell.

Martin, J. R. (2000). "Beyond Exchange: Appraisal Systems in English", en S. Hunston y G.Thompson (Eds.), Evaluation in Text: Authorial stance and the construction of discourse. 142-175. Oxford: Oxford University Press.

Martin, J. R. (2003). "Introduction". Text, 23(2). Special Issue: Negotiating heteroglossia: Social perspectives on evaluation, 1-11.

Martin, J. R., y D. Rose (2003) Working with Discourse: Meaning beyond the Clause. London: Continuum. 
Martin, J. R., y D. Rose (2008) Genre Relations: Mapping Culture London/Oakville: Equinox Publishing Ltd.

Martin, J. R., y White, P. R. R. (2005). The Language of Evaluation: Appraisal in English. Hampshire y New York: Palgrave Macmillan.

Matthiessen, C.M.I.M (1995) Lexicogrammatical Cartography. Tokyo: International Language Sciences Publishers.

McEnery, T \& A. Wilson (1996) Corpus Linguistics. Edinburgh: Edinburgh University Press.

Mignone, E. (1986) Iglesia y dictadura. Buenos Aires: Ediciones del Pensamiento Nacional.

Mills, S. (2003) Gender and Politeness. Cambridge. CUP.

Nunan, D. (1992). Research Methods in Language Learning. Cambridge: CUP

Oteíza Silva, T (2006) El discurso pedagógico de la historia. Un análisis lingüístico sobre la construcción ideológica de la historia de Chile (1970-2001). Santiago de Chile: Frasis.

Oteíza Silva, T (2009) "Solidaridad ideológica en el discurso de la historia: Tensión entre orientaciones monoglósicas y heteroglósicas". Revista Signos [online]. 2009, vol.42, n.70. 219-244

Piñuel, J L (2002). "Epistemología, metodología y técnicas del análisis de contenido". Estudios de Sociolingüística 3(1), 1-42.

Piñuel, J.L. y J.A. Gaitán (1995) Metodología general. Conocimiento científico e investigación en la comunicación social. Madrid: Síntesis.

Samaja, J. (1999) Epistemología y Metodología. Elementos para una teoría de la investigación científica. Buenos Aires: Eudeba, $3^{\circ}$ ed.

Silverman, D. (2001) Interpreting Qualitative Data. London. Sage.

Sinclair, J. (1986). "Fictional worlds", en M. Coulthardt (Ed.), Talking About Text, Discourse Analysis Monograph No 13, ELR. 43-60. Birmingham: University of Birmingham.

Sinclair, J. y Coulthard, M. (1975). Towards an Analysis of Discourse. Cambridge: Cambridge University Press.

Spencer-Oatey, H (ed) (2000) Culturally Speaking. Managing Rapport through Talk Across Languages. New York \& London: Continuum.

Spiazzi, Raimondo (1965) Teologia Pastorale, Didattika Kerigmatica e Omiletica. Roma: Mariettti. 
Swales , J. (1990). Genre Analysis. Cambridge: Cambridge University Press.

Taboada, M.T. (2004) Building Coherence and Cohesion, Amsterdam/Philadelphia: John Benjamins.

Tadros, A. (1993) "The pragmatics of text averral and attribution in academic texts", en M. Hoey (Ed.), Data, description, discourse. 98-114. London: Harper Collins.

Tadros, A. (1994). "Predictive categories in expository prose"., en M. Coulthard (Ed.), Advances in Written Text Analysis. 69-82. London: Routledge.

Threadgold, T. (1989). "Talking about genre: Ideologies and incompatible discourses." Journal of Cultural Studies, 3(3), 101-127. [consulta: 5- 3- 2011]

van de Mieroop, D (2008) "Co-constructing identities in speeches: How the construction of an 'other' identity is defining for the 'self' identity and vice versa". Pragmatics, 2008, vol.18,no.3, 491-509.

van Dijk, T. (1990). La noticia como discurso: Comprensión, estructura y producción de la información. Barcelona: Paidós.

van Dijk, T. (1997). "Cognitive context models and discourse", en M. Stamenow (Ed.). Language Structure, Discourse and the Access to Consciousness. 189226. Amsterdam/ Philadelphia: John Benjamins.

van Dijk, T. (1998) Ideology a Multidisciplinary Approach. London: Sage.

van Dijk, T. (2002) "Tipos de conocimiento en el procesamiento del discurso", en G. Parodi (Ed.), en Lingüística e interdisciplinariedad: Desafíos del nuevo milenio. Ensayos en Honor a Marianne Peronard. 43-66. Valparaíso: Ediciones Universitarias de Valparaíso.

van Dijk, T. (2003) Ideología y discurso. Barcelona: Ariel Lingüística.

van Dijk, T. (2005). "Ideología y análisis del discurso". Utopía y praxis latinoamericana, 29, 9-36.

van Dijk, T. (2008) Discourse and Context. A Sociocognitive Approach. Cambridge: Cambridge University Press.

Vasilachis de Gialdino I (1992) Enfermedades y accidentes laborales. Un análisis sociológico y jurídico, Buenos Aires: Abeledo Perrot.

Ventola, E. (1995). "Generic and register qualities of texts and their realization", en P. H. Fries \& M.Gregory (Eds.), Discourse in Society: Systemic-functional Perspectives. 3-28. Norwood, NJ:Ablex Publishing Corporation. 
White P.R:R. (2003a). "Appraisal- The Language of evaluation and stance", en Bulcaen, C: (ed) The Handbook of Pragmatics. 66-91. Amsterdam/Philadelphia: John Benjamins.

White, P.P:R. ( 2003b)"Beyond modality and hedging". Text 23 (2) 259-284.

White, P (2004). [en línea]. "The Appraisal website; The Language of attitude, arguability and interpersonal positioning" Disponible en http://grammatics.com/appraisal/index.html [consulta: 12 -10- 2008]

Winter, E. (1994). "Clause relations as information structure: Two basic structures in English", en M. Coulthard (Ed.), Advances in Written Text Analysis 45-78. London: Routledge. 
CORPUS *33

Las homilías anteriores al año 1999 fueron tomadas del Boletín Eclesiástico del Arzobispado de Buenos Aires y de los diarios La Nación y La Prensa. A partir del año 1999 las homilías se encuentran publicadas en la página web del Arzobispado de Buenos Aires (http://www.arzbaires.org.ar/Homilias.htm ) 


\section{Homilía Tedeum 25 de mayo 1976*}

3 Celebramos el 166 aniversario de la gloriosa gesta de Mayo, cuando a pocos metros de esta histórica Catedral, nuestros próceres valientemente dieron los primeros y decisivos pasos del proceso de la emancipación, que madurado en la Asamblea del año XIII, culminó con la heroica declaración de la Independencia el 9 de julio de 1816.

En este 25 de mayo, día de júbilo nacional, en que conmemoramos la gestación de nuestra patria independiente, nos hemos reunido, según una antigua y cristiana tradición, para entonar un himno de acción de gracias a Dios, pues Él es la fuente de todo bien, y por tanto también de este gran beneficio que es para el hombre su patria.

Después de Dios, nos enseña Santo Tomás de Aquino, el hombre en el orden natural está obligado y es deudor a sus padres y a su patria. En el principio de nuestra vida, inmediatamente después de Dios y en colaboración con El, se encuentran los padres y la patria. Los padres, de quienes hemos nacido, la patria, en la que hemos nacido. Como no se elige a los propios padres, de suyo tampoco se elige la propia patria, se la tiene de nacimiento, se la recibe de las manos de Dios con un gran patrimonio que viene del pasado y que ya desde su niñez es para el hombre un elemento primordial que nutrirá su vida, influyendo en toda su educación y experiencia humana. Por eso, enseña el mismo Santo Doctor, la patria, así como los padres, es digna de piedad filial, es decir, de un verdadero amor, gratitud, respeto y veneración.

Dios, los padres, la patria. Aquí está la idea profunda de la paternidad, que en Dios se verifica de modo eminente, de la cual participan los padres y que también se realiza en su debida proporción, en la patria, como lo indica su mismo nombre.

La Iglesia, que es madre en el orden sobrenatural, siempre ha inculcado el verdadero amor a la patria siguiendo los ejemplos de N.S. Jesucristo, quien, además de amar profundamente a la patria terrena, se sometió a sus leyes. Recordemos también que este amor a la patria, de suyo natural, es sublimado en el cristiano por la gracia de Dios.

Pío XII se lamentaba que algunos en estos tiempos, temen mostrarse particularmente amantes de su patria y agregaba que este disminuido amor a la patria, a esta gran familia que Dios nos ha dado, es una señal de la actual desorientación de los espíritus (Cfr. AAS. 958, pág. 219)

Debemos, por tanto, cultivar un sano amor a la patria. A ello estimula la Iglesia a sus hijos. Ella, al buscar la salvación, no sólo comunica la vida divina al hombre, sino también difunde la luz evangélica a los problemas de la sociedad civil y trata de proteger y elevar la dignidad y los valores morales de la persona humana. Por eso mismo consolida y da firmeza a la comunidad política donde la Iglesia vive; al predicar la verdad evangélica e iluminar, con su doctrina y el testimonio de sus buenos hijos, los diversos sectores de la actividad humana, la Iglesia anima el estilo de vida y busca el verdadero bien de la comunidad política.

Por esas razones el Concilio Vaticano II enseña que los ciudadanos deben cultivar, con magnanimidad y lealtad el amor a la patria, pero sin estrechez de espíritu, de modo que al mismo tiempo siempre miren por el bien de toda la familia humana (Cfr. G.S.75) e

\footnotetext{
${ }^{*}$ * Homilía tomada del Boletín Eclesiástico del Arzobispado de Buenos Aires . Mayo 1976. Año XIX-N ${ }^{\circ}$ 198
} 
49 insiste que ese amor a la patria debe ser verdadero y eficaz (Cfr. A.G.15), de modo que 50 en los cristianos su originalidad de ser hombres nuevos nacidos en Cristo debe 51 manifestarse en la cultura y tradiciones de su propia nación (Cfr. A.G. 21).

Para que, de acuerdo con las enseñanzas del Concilio Vaticano II los cristianos cultivemos verdadera y eficazmente el amor a nuestra patria, resulta obvio que en la situación presente "es deber de todos contribuir a la recuperación y salvación de la Argentina" (Carta Pastoral del Episcopado Argentino del 16-V-786). Para ello nuestro Episcopado en su último documento nos invita a una profunda conversión de los espíritus y corazones que, por una parte, se esfuerce en hacer respetar siempre los derechos humanos y hacer desaparecer la violencia fratricida, y por otra, haga del bien común el criterio rector de las conciencias de las autoridades y ciudadanos. Sólo así podrán los diversos sectores del país asumir, en la proporción debida a sus posibilidades, la necesaria cuota de austeridad y abnegación que hemos de soportar para superar la delicada situación actual, de modo que el sacrificio pedido no signifique para 64 algunos la renuncia de no sólo un bien superfluo, mientras que para otros lo sea de la 65 satisfacción de una necesidad impostergable.

66

67 Que Dios, Nuestro Señor, nos conceda a todos los argentinos la gracia de amar 68 eficazmente a nuestra patria, de modo que cada uno en su puesto y según sus 69 posibilidades, contribuya de verdad a la tan ansiada recuperación nacional, en la paz, 70 justicia y amor. Así sea. 


\section{Homilía Tedeum 25 de mayo de 1979}

$\mathrm{Al}$ celebrar un nuevo aniversario de la gran gesta de mayo nos hemos vuelto a reunir en esta histórica Iglesia Catedral para agradecer a Dios nuestro señor los innumerables beneficios con que él ha colmado a nuestra querida patria argentina. ¿Y como podría ser de otra manera?

De norte a sur, de este a oeste la extensión y fecundidad de su suelo, la variedad y la abundancia de sus recursos naturales, la belleza de sus paisajes, la benignidad de sus climas y sobre todo la capacidad y laboriosidad de sus habitantes son algunos de los tantos dones con que dios en su bondad previsora ha bendecido nuestra patria.

Nunca habremos agradecido a Dios suficientemente por todos los bienes que, consciente o inconscientemente, a veces, disfrutamos. Por eso vamos a escuchar el Tedeum, el Himno de Acción de Gracias. Por eso vamos a oír "llenos están los cielos y la tierra de la majestad de tu Gloria, Padre de inmensa potestad".

Pero, es indudable también que a la actitud agradecida ha de corresponder también la firme voluntad de hacer desarrollar, cada uno desde su propio rol y según sus posibilidades, las enormes potencialidades espirituales y materiales que el mismo dios nos ha encomendado como vocación.

Ésto supone una clara toma de conciencia, de que el único Dominus, el único Señor, el único dueño de los bienes es Dios y que nosotros, los hombres, no somos sino administradores de ellos que hemos de dar cuenta al mismo Dios del recto uso de los mismos bienes.

Permítaseme recordar en esta magna celebración eucarística, aquella permanente e invariable enseñanza del magisterio de la Iglesia que, desde los primeros padres hasta nuestro días, pasando por los grandes documentos pontificios ha proclamado con toda explicites como lo ha hecho el Concilio Vaticano II, que "Dios ha destinado la tierra y cuanto en ella se contiene para uso de todos los hombres y de todos los pueblos, de modo que los bienes creados deben llegar a todos en forma justa, según la regla de la justicia inseparable de la caridad.

\section{Trabajo y capital}

Resuenan todavía hoy aquellas palabras de Pío XI en la "Quadragessimo Agno": "No es justo que lo que es resultado de la eficaz colaboración del trabajo y el capital, es decir, el beneficio, se lo arrogue una sola de las partes". Remunerados todos los sectores que interviene en la producción, ha de reconocerse también a los trabajadores una parte de los beneficios para lo cual ha detenerse en cuenta no sólo la suficiencia del salario, sino también la condición de la empresa, como así también el bien común, tanto nacional como internacional. La primacía del servicio sobre el lucro, ya que no puede justificarse este ultimo si no corresponde a un verdadero servicio. La primacía por último de las verdaderas y reales necesidades del hombre frente a una desmedida oferta de bienes innecesarios que una sociedad consumista ofrece.

Pero la paz, la convivencia ordenada, fructífera y propia de la dignidad de los hombres, se vivifica e integra en el amor. Donde hay desunión, más allá de la multiplicidad y las legitimas y diferentes opciones, no reina la paz. Reinan la división y la discordia como generadoras de enfrentamientos.

Finalmente la verdadera paz debe ser realizada con libertad. Pero una libertad que no significa ni se define como "hacer lo que se quiere", sino como el " derecho y la obligación de hacer lo que se debe hacer". Una libertad, en fin, que no permita se 
escuchen aquellas frases del célebre Lacordaire, quien decía: "entre el pobre y el rico, entre el débil y el fuerte, es la libertad la que oprime y la ley la que libera".

Hermanos míos en Nuestro Señor Jesucristo: esta paz, que todos anhelamos, que todos queremos exige de nuestro esfuerzo, de nuestro sacrificio pero también exige comprender que sin la ayuda de Dios, con las solas fuerzas humanas no la podemos lograr. Cristo es el Príncipe de la Paz. Por ello al unir nuestros corazones argentinos para agradecer al creador y padre todos los bienes que nos dio, al celebrar gozosamente y reconocidos aquella gesta gloriosa de nuestros próceres, el 25 de mayo de 1810, pidamos al divino redentor la paz que él mismo nos trajo. Pidamos que él borre de los hombres todo lo que pueda poner en peligro esta paz y transforme a todos en testigos de la verdad de la justicia y del amor fraterno.

Al rememorar la revolución de mayo, esa página nunca suficientemente ponderada de nuestra historia, en este mundo cada vez más interdependiente, pidamos también que él ilumine con su luz la mente de los que gobiernan las naciones, para que junto al bienestar y prosperidad convenientes, procuren también a sus conciudadanos el don magnífico de la paz, que cristo finalmente encienda las voluntades de todos para estrechar los vínculos de la mutua caridad para fomentar la mutua comprensión. En fin, para perdonar sus agravios. Así, bajo su acción y amparo, todos los hombres se aúnen como hermanos y florezcan entre ellos y reine siempre la anhelada paz.

\section{Marxismo y liberalismo}

Sí, este mismo magisterio que ha rechazado sin ambigüedades y seguirá rechazando siempre al marxismo materialista y ateo realizador de una dialéctica de violencia, negador al mismo tiempo de la libertad individual y de toda trascendencia del hombre, ha rechazado también sin ambigüedades a la ideología liberal, que cree exaltar la libertad individual substrayéndola a toda limitación, estimulándola con la búsqueda exclusiva del interés y del poder, y por ello si siempre ha defendido el derecho natural de propiedad privada, aún de los medios de producción, frente a los ataques socializantes, no con menos énfasis ha afirmado que "la propiedad privada no constituye para nadie un derecho incondicional y absoluto, que no hay ninguna razón para reservarse en uso exclusivo lo que supera a la propia necesidad cuando a los demás les falta lo necesario".

Sí, vamos a cantar un himno de acción de gracias, pero ello debe comprometernos a todos a reubicar al hombre y en nuestro caso al hombre que habita este bendito suelo, como sujeto, centro, fin y fundamento de toda actividad política, económica, social, cultural y aún religiosa.

Este mismo Creador y Padre, a quien dirigimos nuestra plegaria agradecida, nos ha enviado a su único hijo Jesucristo quien, al asumir nuestra naturaleza humana, en la persona del Verbo compartiendo en todo nuestra condición menos en el pecado mediante su misterio pascual de muerte y resurrección, hizo resplandecer con nueva luz la eminente dignidad de la persona humana.

A partir de la encarnación del verbo de Dios no sólo todos los hombres tienen la misma igualdad esencial de naturaleza, el mismo origen divino y el mismo destino sobrenatural, sino que también todos hemos sido constituidos hijos adoptivos de Dios hermanados en el mismo Jesucristo.

Es a esta luz que el Sumo pontífice JPII a quien hemos agradecido su mediación en el conflicto austral, al inaugurar la III Conferencia General del Episcopado latinoamericano en Puebla de los Ángeles, llamada a renovar la evangelización en el presente y en el futuro de nuestros países, después de recordar a todos los pastores de la 
99 Iglesia y haber declarado magistralmente la verdad sobre Jesucristo y la verdad sobre la 100 misión de la Iglesia, ha proclamado señeramente que la verdad completa sobre el ser 101 humano constituye el fundamento de la Enseñanza social de la Iglesia, así como es la 102 base de la verdadera liberación. A la luz de esta verdad no es el hombre un ser sometido

103 a los procesos económicos o políticos sino que esos procesos están ordenados al hombre 104 y sometidos a Él.

105

106

107

108 Se ha dicho que hay que ganar la paz. Ello es muy cierto. La paz no es la mera ausencia 109 de lucha armada. La `paz no es únicamente la ausencia de violencia que es ciertamente 110 antievangélica y no cristiana. La paz, tranquilidad en el orden, o humana convivencia 111 organizada y fecunda, debe tener también como fundamento que todo ser humano es 112 persona es decir una naturaleza dotada de inteligencia y de voluntad libre y que por 113 tanto, de esta misma naturaleza directamente nacen, al mismo tiempo, derechos y 114 deberes que, al ser universales e inviolables son también absolutamente inalienables.

115 La Paz, para decirlo con palabras de Juan XXIII tomadas de la maravillosa encíclica 116 "Pacem in Terris", será una palabra vacía si no está fundada en el orden moral y por 117 tanto ha de estar cimentada sobre la verdad, construida con las normas de justicia, 118 vivificada e integrada por la caridad y realizada, en fin, con la libertad.

119 Fundamentada sobre la verdad : la cual supone que cada habitante reconozca y respete 120 debidamente los recíprocos derechos y las correspondientes obligaciones desechando 121 toda mentira. Que el criterio de verdad no sea la propia utilidad o el puro provecho 122 personal.

123 Construida con las normas de la justicia: esa justicia que implica no sólo dar a cada uno 124 lo suyo sino también la recta distribución de los beneficios y de las cargas, haciendo 125 recaer los sacrificios no sobre los que menos pueden sino, primeramente, sobre los que 126 más pueden sobrellevarlos.

127 Sobre la justicia que reconoce aquellas grandes e irrenunciables primacías que se 128 desprenden nítidamente de las enseñanzas sociales de la Iglesia: el primado abandono 129 de lo moral sobre lo económico, ya que la economía como las demás actividades debe 130 estar al servicio del hombre y todo lo que se refiere al hombre debe someterse al orden 131 moral. La primacía del trabajo sobre el capital, porque el primero es expresión de la 132 persona humana, necesario y tarea creadora con Dios mientras que el segundo, el capital 133 es un mero instrumento de la producción.. Lo que requiere, conforme lo indica también

134 la doctrina social de la Iglesia, que la generación del trabajo sea suficiente para que el 135 trabajador y su familia puedan llevar una vida digna de personas humanas en el aspecto 136 material, cultural y espiritual.

137 Fuente: Diario La Nación 26 de mayo de 1979.

138 Titulada: Una homilía de hondo contenido. 


\section{Homilía Tedeum 25 de mayo de 1980}

2 En el calendario de este año1980 coinciden la celebración litúrgica de Pentecostés y el

3170 aniversario de nuestro grito patrio de libertad. Pentecostés es la efusión del Espíritu

4 Santo sobre la Iglesia redimida por la sangre preciosa de Jesús salvador. Para usar una

5 analogía así como las grandes obras de ingeniería llevan largos años de preparación-

6 factibilidad, proyectos, construcción-hasta que llega el día solemne de su inauguración y

7 puesta en marcha, algo así ocurre con la iglesia, pueblo de Dios, pacientemente

8 preparada y construida por Jesucristo durante su vida mortal.

9 Cuando Él retorna al Padre, envía al Espíritu Santo quien justamente pone a la Iglesia

10 en actividad misionera para todo el tiempo que dura la historia humana, hasta que él pueblos, como centro y Rey de la Historia, Sol indeclinable de la creación, Lucero indefectible en la noche de los tiempos. Como lo proclama con tanto lirismo el pregón pascual: "Cristo es ayer y hoy, es el principio y el fin, es la A y Z, a quien sean el honor y la gloria, de quien son el tiempo y su historia, por los siglos de los siglos".

\section{El hombre diminuto}

Tal es la celebración de Pentecostés que hoy celebra la Iglesia católica. Frente al Cristo resucitado y victorioso cual lo hemos descrito, el hombre aparece diminuto, aún el más grande por su jerarquía o por su eminencia personal. En la Basílica de San Pablo de Roma hay un espléndido mosaico del Cristo Pentocrator, que se despliega en toda su majestad dominando la asamblea en actitud bendiciente. La figura aparece como aniquilada, cual humilde adorador rezando en tierra al pie del Cristo, majestad de espectaculares proporciones. Parécenos que esta escena se repite en esta solemnidad de Pentecostés y 25 de mayo bajo las bóvedas de esta histórica catedral. Las máximas autoridades de la nación argentina y de la ciudad de Buenos Aires, el cardenal arzobispo primado y sus obispos auxiliares, los representantes de las naciones hermanas y los uniformes de las Fuerzas Armadas para la defensa de la patria-se posternan devotamente ante el cristo rey de la historia, tal cual lo vienen haciendo desde nuestro nacimiento como pueblo anheloso de libertad en 1810 y luego jurídicamente independiente en 1816, para dar gracias a Dios.

La Biblia, libro santo respetado por toda la humanidad, integra en su relato histórico el devenir de un pueblo elegido entre todas las naciones de la tierra. Narra su relación con Dios, sus horas de gloria y sus horas de vergüenza. Los momentos de mayor exaltación nacional de este pueblo coinciden con el más exuberante entusiasmo religioso. Así lo expresan los cánticos de Moisés, de Debora y de David. Por el contrario, la depresión nacional del pueblo va acompañada de un acudimiento al Dios salvador, único que puede salvarlos. Este tema aparece persistente, casi obsesivo, en los grandes profetas. Solo Dios, Él solo, sólo Él, nadie fuera del Él, nadie más que Él, Él basta. "Él rompe los arcos, quiebra las lanzas, quema los escudos; es superior a todos los pueblos poderosos, más alto que la tierra”. (Salmo 46)

\section{Momentos fuertes}

A semejanza de ese pueblo elegido, nuestro pueblo argentino ha vibrado religiosamente en los momentos fuertes de su historia. En sus fechas memorables este pueblo implora a Dios, le alaba, le canta, le pide perdón y le da gracias. Es lo que hacemos en este día y en este momento. 
Oh, Dios Padre por medio de tu hijo Jesús y en Espíritu Santo te damos gracias. Te damos gracias en primer lugar por habernos dado a España como madre patria, por sus reyes visionarios Fernando e Isabel los Católicos que comprendieron e impulsaron la empresa colombina y por todos los grandes monarcas que los sucedieron, por sus valientes fundadores de pueblos, colonizadores, gobernadores, virreyes, misioneros de tu evangelio y sagrados obispos que ornaron nuestras tierras desde el 1500 al 1800.

Te damos gracias por los hijos de aquellas razas bravías que poblaron esta tierra antes de su descubrimiento y colonización; y por las corrientes migratorias que vinieron a poblarla y civilizarla: españoles e italianos, franceses y alemanes, hebreos y árabes, irlandeses y polacos, ucranianos y japoneses, escandinavos y magyares, esclavos y armenios...Todos.

Te damos gracias por la lucidez de nuestros antepasados que llegado el momento preciso ni antes ni después supieron-no sin dolor y sangre- emanciparnos del rey terrenal pero no del Dios eterno.

Te damos gracias por nuestros mares y ríos, por nuestras pampas y sierras por nuestra cordilleras nevadas y nuestros valles, por nuestras cosechas y ganado, por el rocío de nuestro cielo y la fertilidad de nuestra tierra y por todas las riquezas que duermen bajo su suelo esperando que la industriosidad del hombre las despierte.

\section{Apasionamientos}

Te damos gracias por los padres fundadores de nuestra nación: los civiles, los hombres de la espada y los hombres de la cruz. Por aquellos que entre los argentinos son indiscutibles: San Martín, Belgrano, Brown, Fray Mamerto Esquiú; y también por aquellos que no acostumbramos nombrar en público porque el apasionamiento de su hora aún hoy nubla y distorsiona su figura-pero que igualmente amaron, sirvieron y murieron por su patria argentina. Te damos gracias por el 25 de mayo de 1810 que señaló el momento en que buscamos nuestra identidad como pueblo y por el 9 de julio de 1816 cuando publicamos a la faz de la tierra aquella identidad dolorosamente descubierta, como cuando en un parto el hijo se desprende del seno materno, o en una familia el joven se emancipa del hogar paterno que sigue amando, para formar su propia familia.

82 Te pedimos perdón por nuestras luchas entre hermanos, por la larga lista de reyertas 83 fratricidas. Te pedimos perdón por nuestros períodos negros y rojos, por los accesos de 84 ferocidad que periódicamente nos atacan y entenebrecen.

85 Volvemos a darte gracias porque siempre nos das la oportunidad de reaccionar a tiempo, 86 porque no nos castigas como merecemos por nuestras culpas sino que, cual padre

\section{Reconciliación inconclusa}

Te damos gracias por el espíritu de reconciliación nacional-aún inconclusa y siempre en construcción- jurada en 1860 y que se encuentra expresada en el frontispicio de esta catedral en aquella escena de los hijos de Jacob reconciliándose entre sí tras sus querellas, ofensas y equivocaciones. Te damos gracias por la mediación providencial del Santo Padre Juan Pablo II, y te imploramos que conduzcas su gestión de paz al éxito anhelado por todos.

En fin, te damos gracias porque hace ya 350 años obraste en los pagos de Luján aquel portento aquella ternura que hizo que tu madre, la Virgen María, en una humilde imagen de terracota se expresara como nuestra patrona; y porque los colores azul y 
100 blanco de su túnica y manto-más que el azul y blanco de nuestro cielo-inspiraran la 101 creación de nuestra bandera que ornamentan este sitio sagrado, nuestras plazas, nuestros 102 edificios, nuestros cuarteles y nuestros templos y pende sobre nuestros pechos como en 103 aquellas inolvidables jornadas del mundial 78 cuando argentina toda entera se envolvió 104 en sus amados colores.

105

\section{Recuerdo}

107

108 En mi insignificancia me permito, a modo de conclusión, recordar el Salmo 46 que 109 exalta el triunfo de Yahvé a toda esta solemne asamblea de gobernantes y obispos, de 110 soldados y embajadores: el Señor es sublime y terrible. Emperador de toda la tierra; 111 Dios es el Rey del mundo... de Dios son los grandes de la tierra...sólo Él es excelso..."

112 Oh! Cristo que presides a hombres y pueblos, que al final de los tiempos habrás de 113 juzgar a vivientes y muertos, que escrutas los corazones humanos y a quien nada pasa 114 desapercibido pero que mientras dura el tiempo de la historia eres paciente y tolerante, 115 haces brillar sol sobre buenos y malos recibe las gracias que el pueblo argentino a través

116 de sus hijos más representativos te tributa por la mediación de tu madre, la muy 117 clemente, piadosa y dulce Virgen María.

118 Fuente: Diario La Prensa. 26 de mayo de 1980.

119 Titulada: "El pueblo ha vibrado religiosamente en los momentos fuertes de su historia" 


\section{$1 \quad$ Homilía Tedeum 25 de mayo 1987}

2

Dice el salmista, y con él todos nosotros: "Te doy gracias Señor, de todo corazón..." y es justo y necesario que también hoy nosotros lo hagamos reconociendo a Dios como al que "hizo grandes cosas entre nosotros", porque Dios actúa en la historia. Y por tanto, la historia es el resultado conjunto de las acciones de los hombres, la acción de la naturaleza y la acción de Dios.

Por eso tiene sentido nuestra oración (súplica) y por eso tiene sentido nuestra acción de gracias.

\section{Vocación de país grande}

Hoy 25 de mayo, venimos para agradecer por nuestra Patria, que se fue configurando a partir de ese grito de libertad, en ese emprender un camino de autonomía, siendo forjadores y dueños de un propio destino...

Un destino de grandeza, que no rechaza ni se rebela con actitudes inmaduras contra una rica tradición recibida, sino que quiere asumirla y proyectarla hacia un futuro..., pero con libertad y la responsabilidad del que se siente dueño de una historia que nace, y es a partir de ese momento que se escribirán las grandes páginas de nuestra Patria.

Y Dios la fue guiando y acompañando, y sobre todo bendiciendo. Cuánta responsabilidad nos cabe... La Patria es un don que recibimos y que deseamos fructificar. La Argentina no puede traicionar esa vocación de país grande y líder que Dios le puso, ni a tantos hombres que dieron su vida para hacer de nuestra Patria una gran Nación.

Sin duda que por ser histórica la cultura es una realidad dinámica, susceptible de trasformaciones, pero que más allá del modo y profundidad de la reformulación que de esa escala de valores se replantee en una nación, siempre tiene que ajustarse a ciertas normas, y también que la misma identidad y continuidad histórica de la nación, exige que se mantengan características esenciales incorporadas a la nacionalidad. Sin duda que hay muchos valores cristianos que están en condiciones en nuestra querida Patria Argentina, y hoy más que nunca se exige prudencia y sabiduría para descubrirlos y respetarlos.

\section{Momento difícil}

Nuestro país vive hoy momentos muy especiales, trascendentales...las generaciones futuras esperan que seamos capaces de transitarlos con grandeza y que seamos así fieles a la herencia de los próceres.

Es éste un momento difícil pero a la vez grande y trascendente.

Nos toca vivir la enorme gracia de la visita del Santo Padre. El nos habló a los católicos. Pero destacó también que hablaba a todos los argentinos.

Nos dio su mensaje que se manifiesta en el orden político, social, económico y nos enseñó que "descubriendo a Cristo" descubrimos la dignidad más honda del Hombre, y que es en Cristo donde encontramos el sentido más profundo de todas las realidades temporales y de las relaciones entre los hombres.

Tenemos que ser capaces de comprometernos, de alzar nuestra voz al cielo en una expresión de corazón sincero.

Nuestra capacidad en un "manos a la obra"

Trabajemos para que esa Paz se logre por la Paz que nace de un corazón nuevo. Todos debemos ser artífices de la Paz, con creatividad, renuncia y sacrificio. 
51 Y vuelven a decir con las palabras de Juan Pablo II:

52 "Una profunda reconciliación fraterna que hunda sus raíces en la reconciliación de cada 53 uno con Dios nuestro Padre, que destierre siempre los odios y rencores en esta hermosa 54 y hospitalaria tierra argentina, de modo que triunfe en todos los corazones la Justicia y 55 la Paz de Cristo".

56 Y todo con humildad de corazón asumiendo cada uno la responsabilidad que tenemos 57 en los errores y omisiones que nos tienen que hacer capaces de aprender para volver a 58 empezar.

59 Nuestra historia reciente de confusión, violencia y desencuentro ha marcado a nuestra 60 Patria con un gran dolor y sufrimiento, que aún cuesta superar.

61 Así como nuestros próceres de mayo que caminaron por la historia iluminados por la 62 presencia cristiana, hoy seguimos el camino. A veces un poco desorientados y 63 abatidos...como los discípulos de Emaús sin reconocer la presencia del Señor en 64 nuestra historia.

65 Que podamos como ellos, al final expresar con fe "Señor, quédate con nosotros" sigue 66 acompañando la historia de nuestra Patria...

67 Aquí estamos hoy, ante nuestro señor, representantes del Gobierno y de la Iglesia, dos 68 realidades, una política y otra sobrenatural y misteriosa. En rigor, representantes de dos 69 aspectos de una misma realidad que es el Hombre.

\section{Revalorizar el concepto de Patria}

Festejamos hoy el nacimiento de nuestra Patria, y es importante que reflexionemos y revaloricemos el concepto de Patria.

Una Patria que no es sólo un territorio geográfico o una mera suma de hechos históricos, sino que implica "fundamentalmente la comunidad de hombres congregados para diversos aspectos, pero sobre todo por el vínculo de una misma cultura. Reunidos así por una idéntica concepción del hombre y del mundo y por una sola escala de valores, que se traducen en actitudes, costumbres e instituciones comunes" (77)

"La cultura otorga a la Nación su propia identidad, y así una soberanía fundamental" (79)

83 Somos depositarios de ideales, valores, dones que cortaron vidas y esfuerzo de generaciones, y por tanto, somos responsables de que con nuestro trabajo hacerlos fructificar en realidades de paz, justicia, libertad, prosperidad. 


\section{Homilía de Tedeum del 25 de mayo de $1993^{*}$}

La conmemoración del 25 de mayo vuelve a reunirnos en la catedral de Buenos Aires, testigo de la historia nacional, acaso con la esperanza de oír en este antiguo recinto el eco de aquellas jornadas de 1810.

Al venir a dar gracias a Dios por estos 183 años de emancipación, surge en nuestro interior una pregunta liminar: ¿Qué honramos al honrar a la Patria? Sentimos por ella una profunda pasión, tan nítida, que nunca se confunde con los otros amores que llevamos en el alma. Lo intuimos único y sabemos que, en la común escala de valores de todo ciudadano, está más allá de los otros sentimientos, relacionado inmediatamente con el mismo amor a Dios, como toda virtud reuniendo la multiplicidad de bien querer que brindamos a los demás.

\section{Qué es la Patria}

Parece fácil definirla, pero son tantos los conceptos que encierra que nada resulta más difícil. Tal vez nos ayude la intuición de los poetas, para decir en una sola frase que Patria es el suelo natal y la tierra soñada. Afirmación que suena a raigambre a tradiciones; a un modo de ser y de vivir común a todos; a valores recibidos que se transmiten a las generaciones nuevas. Pero suena también a prospectiva; a futuro; a deseo de no agonizar en el inmovilismo de las realidades que fueron, sino a fundar en ellas el desarrollo: aquel horizonte mejor que buscamos para hacerla más noble aún y cada vez más adecuada a las condiciones de los tiempos.

Patria es a la vez lo hecho: historia forjada lentamente; el idioma que unifica y la sangre nueva que congrega distintas etnias y culturas. Es pasado que se hereda se transmite; pero también es futuro que se aborda en comunidad.

En su seno se conjugan los criterios fundantes y los aportes de la modernidad, para inserir en ellos las verdades a las que nunca renunció, sobre la dignidad del hombre y su igualdad esencial; el derecho inalienable a la vida, a la educación, a la justa distribución de los bienes de la tierra y los frutos de la economía; y a la plena participación política. Todas surgen del convencimiento de que el hombre está llamado a ser hijo de Dios y a vivir según esa lúcida conciencia.

\section{Independencia marcada por principios cristianos}

Por eso nos convoca a preservar los valores que la sustentan desde el momento en que el pueblo comenzó la gestión de auto gobierno y marcó el hito inicial de su camino hacia la independencia. Entonces asumió un estilo de vida no impuesto por otros, sino elegido por sí misma.

Nos recordaba el Papa cuando estuvo en Tucumán, que la cultura anterior a la independencia, marcada por principios cristianos y por sentimientos caros a nuestra sociedad, dio lugar a un estilo de vida inspirado en ideales de justicia, fraternidad y amor (cnf. Tucum.5; Mensajes-Paulinas 1987)

La Argentina bebió en esas fuentes; y nuestros próceres tuvieron la sabiduría de crear un nuevo esquema político, soberano y libre, sin renunciar en sus realizaciones a los valores arraigados ya en el corazón de los habitantes

\footnotetext{
*Homilía pronunciada por Su Excia. Rvma. Mons. Eduardo V. Mirás, obispo auxiliar y vicario general a cargo del gobierno de la arquidiócesis de Buenos Aires en la Catedral metropolitana durante la Celebración Litúrgica del 25 de mayo de 1993. Tomada del Boletín Eclesiástico del Arzobispado de Buenos Aires. Mayo 1993. Año XXXVI-N 330
} 
47 Esto no dice que aquel deseo de libertad que fue la mística de Mayo y debe ser nuestro 48 futuro, no se refiera exclusivamente a eventuales presiones extranjeras, sino también a 49 las falsas opciones que puedan aparecer en la misma sociedad nacional e impliquen 50 violencia, injusticia o desprecio por los derechos de alguno. Solamente con respeto, 51 justicia y amor por los demás se perdura como Nación libre. Nos dice la Sabiduría de 52 Ben Sirac en la Sagrada Biblia, que la soberanía se transfiere de una Nación a otra, a

\section{Sin dimensión ética no hay libertad}

Es necesario asumir la "libertad con que nos liberó Cristo", nos dice Pablo (Gal.5,1). Esa que es amor. Porque sólo es libre quien intenta el bien para sí mismo buscándolo para todos. El egoísmo, la falta de solidaridad, la avaricia, la corrupción, siempre serán esclavitud. En el Evangelio proclamado hoy, Jesús nos advierte precisamente que todo el que peca es esclavo del pecado ( cnf. Jn. 8,34). Sin dimensión ética no hay libertad. La experiencia nos enseña que la libertad se arraiga en un pueblo, cuando busca la prosperidad por el camino de la justicia y la fraternidad; cuando las oportunidades de calidad de vida son ofrecidas a todos, como una obligación de la sociedad y no como un privilegio de pocos.

Los deberes con Dios y con la Nación, nunca deberían entrar en conflicto. Saber que la Patria de un hombre no es su Dios, encauza el amor por ella y aleja la tentación de los nacionalismos ciegos y extremos, que son violencia; y la torpeza moral de la falsa prudencia que quiere cohonestar en la legislación, cualquier novedad en las costumbres sin juzgar su valor ético, como si el orden moral que la ley expresa, no fuera más que una formalidad. Tomás de Aquino enseña que la violencia del poderoso y la falsa prudencia del sabio corrompen la justicia.

\section{Noble tarea del legislador}

Por eso, en la noble tarea de legislar es preciso tener presente que no puede hacer Patria sin atender a la ley del Señor. Nos dice Isaías que la Nación que no se someta a dios será arruinada (cnf. Is. 60,12).

Esta prevención corresponde especialmente a quienes el pueblo elige para establecer el marco legal que haga posible y digna la vida en sociedad. Aunque se acceda a la legislatura por medio de los distintos grupos políticos que tienen su particular orientación, el legislador jamás debería anteponer los intereses partidarios al bien común.

Su tarea se dignifica con la constante preocupación por el bien del hombre y el respeto a la igual dignidad de cada uno; se envilece, en cambio, con la parcialidad o la afrenta; con el uso de argucias formales para evitar el discurso serio de los problemas que aquejan a la Republica; y con la visión unilateral de la realidad.

\section{Los derechos de los ciudadanos}

El individuo se fue haciendo cada vez más conciente de que la sociedad tenía para con él determinados compromisos en el orden político y social: y que las instituciones de la Nación gozaban de grandes posibilidades para satisfacerlos.

Esa mayor conciencia dio como resultado a lo largo del tiempo la corrección de inveterados abusos. Y así, tímidamente al principio, fueron apareciendo en el País instrumentos que hacían efectivo el reconocimiento de los derechos de los ciudadanos, 
como instrucción pública, la salud, el salario justo, el descanso dominical, cuya finalidad no se agota en lo cultural, porque también contribuye a la unidad y convivencia familiar, y a la amistad social; la libertad de expresión y el voto de la mujer. Leyes perfectibles como toda obra humana que sin embargo deberían ser irrevocables en cuanto involucran a toda la comunidad y responden al bien de la sociedad misma. Otras conquistas sectoriales podrían requerir nuevo análisis, si las prerrogativas de un grupo social, hicieran peligrar la equidad que requiere el resguardo del bien común. Porque la ley siempre tiene como objetivo último el beneficio de toda la comunidad.

\section{La corrupción hace imposible la armonía social}

Este día de reflexión nos recuerda que aquel 25 de mayo de 1810 fue el comienzo de nuestro existir como Nación soberana, frente al concierto de los pueblos; pero también el origen de nuestra igualdad política en la comunidad nacional. El necesario marco del bien común, que no es la suma de los bienes particulares sino el bien de la sociedad misma, regula la acción de cada uno para que se consolide en armonía el siempre frágil entretejido social que, tanto el desborde personal o sectorial, como la corrupción, harían imposible.

La urdimbre de la sociedad se hace con las obligaciones que cada individuo tiene con el todo. Por eso debemos reconocer que no hay Patria sin lealtad ciudadana. Y es imposible la lealtad sin el cumplimiento de la ley justa que, en definitiva, tiene su fundamento en la misma naturaleza del hombre y en los mandamientos de Dios. El profeta Jeremías nos enseñan que la lealtad se pierde cuando la Nación no escucha la voz de Dios ni cumple con su ley (cnf. Jer.7,28).

\section{Es obligación de todos el cumplimiento de la ley justa}

Es responsabilidad irrenunciable de la autoridad legítima el ordenamiento de la diversidad y la recapitulación de los diferentes puntos de vista para que todos se sientan protagonistas sin que las apetencias distintas y a veces contradictorias de los ciudadanos acaben debilitando a la Nación. Y es obligación de todos el cumplimiento de la ley justa. Para ello, San Pedro en su primera carta nos aconseja ser obedientes a toda autoridad humana, por respeto al Señor (cnf. I Pe.2,13). Y el cuarto mandamiento nos obliga a la gratitud con el País, como nos obliga con nuestros propios padres. El hombre es deudor de la sociedad; y la sociedad nacional no sobrevive sin e amor activo de los ciudadanos por ella. Amor que trascienda la declamatorio y se exprese en actitudes que la engrandezca. El mandamiento de piedad para con la Patria. Y para el cristiano esto es una virtud porque la piedad está incluida en la religión.

La religión despierta y garantiza en el ciudadano la vocación patriótica y a la vez exige del funcionario un ejercicio estrictamente ético al servicio de la comunidad; y de los ciudadanos, el cumplimiento de toda la normativa que haya tenido legítimo origen y esté ordenada al bien común: porque toda ley justa trasciende lo legal, para obligar moralmente.

Hoy venimos a dar gracias a dios por la Patria y a elevar nuestra plegaria por su prosperidad. No dudamos en ofrecer al Señor, en nombre de todos los ciudadanos del País el compromiso de ser fieles a la herencia de nuestros mayores y de imaginar y forjar para la Argentina un mañana más próspero y más justo, atentos a la voluntad de Dios, fuente de toda razón y justicia y garantía definitiva de todos los derechos del hombre. 


\section{Homilía de Tedeum del 25 de mayo de $1996{ }^{*}$}

Estamos recordando el centésimo octogésimo sexto aniversario de los acontecimientos de mayo cuando se dieron los primeros pasos para el ingreso argentino en el listado de las naciones libres. Ello aconteció y definitivamente el 9 de julio de 1816.

En todo ese proceso hay dos elementos insustituibles. El primero, fue que como hija mayor por su voluntad la Argentina quiso independizarse la Madre Patria, España; el segundo, su voluntad de no querer independizarse de Dios y de la Iglesia Católica, lo que no significaba irrespeto a otras confesiones religiosas. Es verdad que esos dos elementos fueron luego enturbiados por grupos, ideología y corrientes, por un lado antihispánicos y anticatólicos, por otro. Pese a ello la población no perdió la fe en la que fue evangelizada y cabe recordar que fue un presidente argentino quien estableció el 12 de octubre como el Día de la Raza.

Mucho se ha escrito sobre la Argentina en los últimos cuarenta años; fueron autores nuestros y también extranjeros. Me he preguntado si de toda esa literatura se podrá extraer una imagen acabada, certera y justa. En este momento recuerdo que en alguna oportunidad tuve la ocasión de referirme a esta entrañable argentina como el país de las oportunidades perdidas y, con un lenguaje que yo mismo calificaba de excesivo, el país de las excelencias decapitadas o veneraciones hinchadas por excesivas. Aducía razones de lo primero, que no expondré aquí y ahora; con lo segundo quería decir que parecería que si alguien en distintos aspectos de la sociedad se constituía en figura destacada, de primer nivel, o se lo decapitaba-atacándolo- o se lo rodeaba de olvido y silencio, o, por el contrario, se sobrevaloraban mediocridades. Me permito decir que, pasados unos años, sigo pensando lo mismo. ¿Será éste nuestro pecado nacional? Al menos merece un examen de conciencia.

Todos saben que ante la entrada en el tercer milenio, el Papa ha convocado a la Iglesia para la celebración de un Jubileo en el año 2000; y en un documento ha lanzado las líneas para una cabal preparación durante los años que concluyen el sigo XX. En esas líneas figura como preparación un examen de conciencia aquí en la Argentina, que algunos medios han utilizado como reto lanzado al rostro de la Iglesia.

No hace muchos días el Episcopado Nacional reunido en Asamblea Plenaria, ha dado a conocer su examen de conciencia. Dígase de paso que el Episcopado ha sido uno de los primeros, si no el primero, en publicar un documento preparatorio siguiendo puntualmente los diversos ítems que el Santo Padre nos recuerda respecto a dicho examen de conciencia, ahora, en este día especial de la Patria, me permito señalar que estaría bien que en los umbrales del próximo siglo, hicieran también su examen de conciencia las diversas estructuras del ser y quehacer nacional; para ver fallos y logros durante este siglo, y así asegurar los segundos y corregir los primeros en el transcurso del Tercer Milenio.

\footnotetext{
** Homilía pronunciada por Su Excia. Rvma. Cardenal Antonio Quarracino, arzobispo de Buenos Aires y primado de la Argentina, en la Catedral metropolitana durante la Celebración Litúrgica del 25 de mayo de 1996.Tomada del Boletín Eclesiástico del Arzobispado de Buenos Aires. Mayo 1996. Año XXXIX-No 363
} 
Me pregunto si no sería bueno que los partidos políticos, todos, tradicionales o no, hayan ejercido o no el poder en alguna área del mismo, se preguntaran hasta dónde fueron instrumentos positivos para el bien de la sociedad entera, dejando de lado los intereses particulares y tratando de insuflar esfuerzos y sacrificios alejándose siempre de la demagogia, con promesas a veces cómicas, la mentira, y el favoritismo y los slogans $\mathrm{y}$ frases hechas tan engañosos como partidistas, cuando no ideologizados.

¿Sería superfluo que la clase empresaria, en sus diversos ámbitos, examinara si el interés de sus correspondientes empresas aportaron al desarrollo del país, sin dejar de cumplir con sus obligaciones y procurando no herir los derechos de sus colaboradores y obreros?

Nadie ignora la influencia y características de quien ha sido denominado "cuarto poder": el periodismo, digamos mejor, desde hace unos años, los Medios de Comunicación Masiva o Social. Ellos también debieran hacer su examen de conciencia tanto más porque es indiscutible su influencia. ¿La verdad, la honestidad el respeto, la decencia que evita tanto lo soez como la mentira y la calumnia, no son exigencias de la función que ha abrazado el que se siente o se cree inclinado a ser transmisor de la palabra escrita u oral?

También le cabe el examen de su acción a las diversas asociaciones, sean de carácter obrero, gremial, cultural y social, para ver si sus acciones o reacciones correspondieron y corresponden a los fines para los cuales fueron creadas y advirtiendo que sus creadores nunca las antepusieron al bien del país y de su pueblo. Hacer este examen de conciencia no es una expresión de masoquismo o un camino al pesimismo: creo que es un verdadero acto de patriotismo.

La teología católica incluye el patriotismo, el amor a la Patria, entre las manifestaciones de la virtud de piedad, lo que lleva a Santo Tomás de Aquino, el máximo doctor de la Iglesia, a afirmar: "después de Dios, son también principios de nuestro ser y gobierno los padres, que de ellos hemos nacido; y la Patria puesto que en ella nos hemos criado. Por tanto, después de Dios, a los padres y a la Patria es quienes más debemos".

Patria es decir padres, país, tradiciones, cultura, paisaje, territorio, sentimientos que podemos calificar de naturales, tanto que frente a algún traidor a esas realidades o a quien reniega de ellas decimos que es un mal nacido. Jesucristo por a amor a su Patria lloró ante la visión de la cercana destrucción de Jerusalén, la capital, en su Pasión se preocupa por los males que de ahí se seguirán para su pueblo (Lc. 23,27-31).

Mas no hay que confundir el patriotismo con el chauvinismo que es la exageración de anteponer al propio país sobre todos los otros. Un patriotismo así acaba por ser patriotería. Que no es lo mismo que nacionalismo, palabra y concepto que fue degradado por lamentables excesos en el que se cae cuando se coloca a la Nación o al Estado como término absoluto de los ideales y norma suprema de conducta. Este exceso es tan repudiable como aquel otro negativo que algunas veces se ha expresado en frases como esta "mi Patria es el mundo"; o peor "mi Patria es donde como".

El sentimiento patriótico de un ciudadano católico debe llevarlo a amar a su Patria sin cerrar los ojos a las glorias y valores de otros países, agradecer a Dios que hayan existido y tomar ejemplo de ellas para su propio bien. Y no se diga, como alguna vez se ha dicho, que el católico porque espera y tiene en el alma la esperanza de la Patria 
95 Futura, de la eternidad de Dios, donde no existirán diferencias, en el cielo, se evade de

96 la patria terrenal y sus problemas y exigencias.

97

98 Por ello el mismo San Pablo que nos dice: aquí no tenemos "morada permanente" 99 proclama con orgullo su condición de israelita y proclama las posibilidades de salvación

100 de su pueblo (2 Cor 11, 22/Rm.11,1 y sg)

$101 \mathrm{Al}$ agradecer a Dios todos los dones con que enriqueció a nuestra Patria, nuestra súplica 102 debe dirigirse al presente y al futuro.

103

104 Todos sabemos en la hora actual el país tiene muchos problemas que resolver. Quizás 105 no recordamos que ello no sucederá sin el esfuerzo de todos, sin egoísmos ni cerrazones

106 mentales. No es con agravios como se resuelven los problemas, sino con apertura de 107 mente y corazón.

108

109 Es un hecho ya advertido en la inmediata post-guerra, la globalización que algunos 110 llaman "mundialización". El mundo se ha convertido en una "gran aldea". Que ese 111 fenómeno no desarraigue de nuestro espíritu el sentido de pertenencia y amor de Patria, 112 el auténtico patriotismo. Pero nosotros tampoco nos enredemos en lo que llamaría 113 problemáticas o rencillas "domésticas" o peleas barriales o presentarnos como los 114 únicos e impolutos salvadores, que son maneras de descuidar los verdaderos serios 115 problemas de la Nación.

117 Roguemos a la Virgen de Luján, Patrona de la patria, que la conduzca por los caminos 118 del desarrollo, la justicia y la paz.. 


\section{$1 \quad$ Homilía de Tedeum 25 de mayo de 1999}

2 Ese mismo día, dos de los discípulos iban a un pequeño pueblo llamado Emaús, situado

3 a unos diez kilómetros de Jerusalén. En el camino hablaban sobre lo que había

4 ocurrido. Mientras conversaban y discutían, el mismo Jesús se acercó y siguió

5 caminando con ellos. Pero algo impedía que sus ojos lo reconocieran.

6 El les dijo: "¿Qué comentaban por el camino?". Ellos se detuvieron, con el semblante 7 triste, y uno de ellos, llamado Cleofás, le respondió: "¡Tú eres el único forastero en 8 Jerusalén que ignora lo que pasó en estos días!". "¿Qué cosa?", les preguntó. Ellos 9 respondieron: "Lo referente a Jesús, el Nazareno, que fue un profeta poderoso en obras 10 y en palabras delante de Dios y de todo el pueblo, y cómo nuestros sumos sacerdotes y 11 nuestros jefes lo entregaron para ser condenado a muerte y lo crucificaron. Nosotros 12 esperábamos que fuera él quien librara a Israel. Pero a todo esto ya van tres días que 13 sucedieron estas cosas. Es verdad que algunas mujeres que están con nosotros nos han 14 desconcertado: ellas fueron de madrugada al sepulcro y al no hallar el cuerpo de 15 Jesús, volvieron diciendo que se les habían aparecido unos ángeles, asegurándoles que 16 él está vivo. Algunos de los nuestros fueron al sepulcro y encontraron todo como las 17 mujeres habían dicho. Pero a él no lo vieron".

Jesús les dijo: "¡Hombres duros de entendimiento, cómo les cuesta creer todo lo que anunciaron los profetas! ¿No era necesario que el Mesías soportara esos sufrimientos para entrar en su gloria?" Y comenzando por Moisés y continuando con todos los profetas, les interpretó en todas las Escrituras lo que se refería a él. Cuando llegaron cerca del pueblo adonde iban, Jesús hizo ademán de seguir adelante. Pero ellos le insistieron: "Quédate con nosotros, porque ya es tarde y el día se acaba". El entró y se quedó con ellos. Y estando a la mesa, tomó el pan y pronunció la bendición; luego lo partió y se lo dio. Entonces los ojos de los discípulos se abrieron y lo reconocieron, pero él había desaparecido de su vista. Y se decían: "¿No ardía acaso nuestro corazón, mientras nos hablaba en el camino y nos explicaba las Escrituras?".

En ese mismo momento, se pusieron en camino y regresaron a Jerusalén. Allí encontraron reunidos a los Once y a los demás que estaban con ellos, y estos les dijeron: "Es verdad, jel Señor ha resucitado y se apareció a Simón!". Ellos, por su parte, contaron lo que les había pasado en el camino y cómo lo habían reconocido al partir el pan. Del Evangelio de san Lucas (Cap.24, vers.13-35)

Una nueva celebración del incipiente comienzo de la conciencia patriótica, aquel Mayo de los argentinos, nos congrega para dar gracias por los dones de Dios Padre, dones por los que nuestros padres supieron - dura y trabajosamente - vivir, luchar y morir. Dar gracias lejos de la nostalgia estéril o del recuerdo formal desaprensivo, y dejar que este mismo Dios Padre nos sacuda en este fin del milenio y nos invite a buscar un nuevo horizonte. Dar gracias porque todavía resuena en esta Catedral ( también 'solar de mayo' ) aquella invitación del Santo Padre en su visita a nuestra Patria : "¡Argentina, Levántate!", a la que todo habitante de este suelo está invitado, más allá de su origen, y con la sola condición de tener buena voluntad para buscar el bien de este pueblo. Aquel ¡Argentina, Levántate!", invitación que hoy queremos volver a escuchar, constituía un diagnóstico y una esperanza. Levantarse es signo de resurrección, es llamado a 
revitalizar la urdimbre de nuestra sociedad. La Iglesia en la Argentina sabe que éste es un pedido de nueva evangelización de su propia vida interna pero - que a la vez - se extiende a toda la sociedad.

En el pasaje del Evangelio que acabamos de oír hay una pedagogía del Señor que nos puede dar luz para que seamos fieles a nuestra misión de padres, gobernantes, pastores... para que seamos fieles a nuestro 'ser pueblo'. Una pedagogía de la cercanía y del acompañamiento. El relato se refiere a los dos discípulos de Emaús y nos muestra su caminar que, más que andar, era huida. Efectivamente escapan de la alegría de la Resurrección, mascullan sus amarguras y desilusiones, y no pueden ver la nueva Vida que el Señor ha venido a ofrecerles. Acudiendo a la frase papal mencionada podríamos decir que no se habían levantado de su adormecimiento interior y - por tanto - estaban incapacitados de ver ese Don de vida que marchaba a su lado y que esperaba ser hallado.

Los argentinos marchamos por nuestra historia acompañados por el don creado de las riquezas de nuestras tierras y por el Espíritu de Cristo reflejado en la mística y el esfuerzo de tantos que vivieron y trabajaron en este Hogar, en el testimonio silente de los que dan de su talento, su ética, su creatividad, su vida. ; Este pueblo comprende hondamente lo que significa el amor a su tierra y la memoria de sus convicciones más profundas ! En su religiosidad más íntima, en la siempre espontánea solidaridad, en sus luchas e iniciativas sociales, en su creatividad y capacidad de goce festivo y artístico, se refleja el Don de Vida del Resucitado. Porque somos un pueblo capaz de sentir nuestra identidad más allá de las circunstancias y adversidades, somos un pueblo capaz de reconocernos en nuestros diversos rostros. Tanto talento no siempre se ha visto acompañado por proyectos con continuidad en el tiempo, ni logró convocar siempre la conciencia colectiva. Y, por ello, como los discípulos huidizos, podemos encontrarnos acaparados por cierta amargura en nuestra marcha, fatigados por problemas que no dejan vislumbrar la urgencia de un futuro que nunca parece llegar.

La fatiga y la desilusión no permiten ver el peligro principal. El actual proceso de globalización parece desnudar agresivamente nuestras antinomias: un avance del poder económico y el lenguaje que lo asiste, que - en un interés y uso desmedido - ha acaparado grandes ámbitos de la vida nacional; mientras - como contrapartida - la mayoría de nuestros hombres y mujeres ve el peligro de perder en la práctica su autoestima, su sentido más profundo, su humanidad y sus posibilidades de acceder a una vida más digna. Juan Pablo II, en su Exhortación Apostólica 'Ecclesia in America' se refiere al aspecto negativo de esta globalización diciendo : "...si la globalización se rige por las meras leyes del mercado aplicadas según las conveniencias de los poderosos, lleva consecuencias negativas : ...la atribución de un valor absoluto a la economía, el desempleo, la disminución y el deterioro de ciertos servicios públicos, la destrucción del ambiente y de la naturaleza, el aumento de la diferencia entre ricos y pobres y la competencia injusta que coloca a las naciones pobres en una situación de inferioridad cada vez más acentuada..." ( $\left.n^{\circ} 20\right)$. Junto a estos problemas planteados ya en el plano internacional nos encontramos también con una cierta incapacidad de encarar problemas reales. Entonces, a la fatiga y la desilusión parecería que sólo se pueden contraponer tibias propuestas reivindicativas o eticismos que únicamente enuncian principios y acentúan la primacía de lo formal sobre lo real. O, peor aún, una creciente desconfianza 
91

92

93

94

95

96

97

98

99

100

101

102

103

104

105

106

107

108

109

110

111

112

113

114

115

116

117

118

119

120

121

122

123

124

125

126

127

128

129

130

131

132

133

134

135

y pérdida de interés por todo compromiso con lo propio común que termina en el 'sólo querer vivir el momento' en la perentoriedad del consumismo. No nos podemos permitir ser ingenuos: la sombra de una nube de desmembramiento social se asoma en el horizonte mientras diversos intereses juegan su partida, ajenos a las necesidades de todos. El vacío y la anomia pueden despuntar como oscuras consecuencias de un abandono de nosotros mismos y atentan contra nuestra continuidad. ¿Quedaremos los argentinos, como los discípulos de Emaús, presos del amargo asombro, de la murmuración quejumbrosa? ¿O seremos capaces de dejarnos sacudir por el llamado del Resucitado a los discípulos desolados, y reaccionar, hacer memoria de la palabra profética, memoria de aquellos momentos salvíficos, constructivos de nuestra historia?

\section{III}

Como en la Pasión de Cristo nuestra historia está llena de encrucijadas, de tensiones y conflictos. Sin embargo, este pueblo de fe supo cargar al hombro su destino cada vez que en la solidaridad y el trabajo forjó una amistad política de convivencia racial y social que marca nuestro estilo de vida. Los argentinos supimos 'ser parte', sentirnos 'parte de', supimos acercarnos y acompañarnos. Desde su capacidad de creatividad individual y colectiva y desde su ímpetu de espontánea organización popular, nuestro pueblo ha conocido momentos fundantes de cambios civiles, políticos y sociales; logros culturales y científicos que nos sacaron del aislamiento y demostraron nuestros valores. Momentos que, en definitiva, nos dieron un sentido de identidad más allá de nuestra compleja composición étnica e histórica. Momentos en los que privó una conciencia de trabajo fraterno, a veces poco elaborado, pero siempre sentido y vivido hasta el heroísmo. Por eso el llamado es a dejar el estéril historicismo manipulado por intereses o ideologismos o por meros criticismos destructivos. La historia apuesta a la verdad superior, a rememorar lo que nos une y construye, a los logros más que a los fracasos. Y mirando al dolor y al fracaso, que nuestra memoria sea para apostar a la paz y al derecho... y si miramos a los odios y violencias fratricidas, que nuestra memoria nos oriente a que predomine el interés común. Los últimos años, tardía y cruelmente, nos han sacudido y la silenciosa voz de tantos muertos clama desde el cielo pidiendo no repetir los errores. Sólo eso dará sentido a sus trágicos destinos. Como a los discípulos caminantes y temerosos hoy se nos pide caer en la cuenta de que tanta cruz cargada no puede ser en vano.

El llamado a la memoria histórica también nos pide profundizar nuestros logros más profundos, aquellos que no aparecen en la mirada rápida y superficial. No otro fue el esfuerzo de estos últimos tiempos por afirmar el sistema democrático superando las divisiones políticas, que parecían un hiato social casi insalvable : hoy se busca respetar las reglas y se acepta el diálogo como vía de convivencia cívica. Dejar la nostalgia y el pesimismo y, como los discípulos de Emaús, dar lugar a nuestra sed de encuentro : "Quédate con nosotros porque ya es tarde y el día se acaba". El Evangelio nos marca el rumbo : sentarnos a la mesa y dejarnos convocar por el gesto profundo de Cristo. El pan bendecido se debe compartir. El mismo que es fruto del sacrificio y del trabajo, que es imagen de la vida eterna, pero que debe realizarse ya.

\section{IV}

En efecto, hermanos, no es una mera invitación a compartir, no es sólo reconciliar opuestos y adversidades : sentarse a partir el pan del Resucitado es animarse a vivir de 
136 otra manera. Nos desafía ese pan hecho con lo mejor que podemos aportar, con la 137 levadura que ya fue puesta en tantos momentos de dolor, de trabajo y de logros. El 138 llamado evangélico de hoy nos pide refundar el vínculo social y político entre los 139 argentinos. La sociedad política solamente perdura si se plantea como una vocación a 140 satisfacer las necesidades humanas en común. Es el lugar del ciudadano. Ser ciudadano 141 es sentirse citado, convocado a un bien, a una finalidad con sentido... y acudir a la cita. 142 Si apostamos a una Argentina donde no estén todos sentados en la mesa, donde 143 solamente unos pocos se benefician y el tejido social se destruye, donde las brechas se 144 agrandan siendo que el sacrificio es de todos, entonces terminaremos siendo una 145 sociedad camino al enfrentamiento.

146 Desde lo profundo de nuestra conciencia de pueblo solidario, este llamado a compartir 147 el pan tiene su honda efervescencia. En la retaguardia de la superficialidad y del 148 coyunturalismo inmediatista (flores que no dan fruto) existe un pueblo con memoria 149 colectiva que no renuncia a caminar con la nobleza que lo caracteriza : los esfuerzos y 150 emprendimientos comunitarios, el crecimiento de las iniciativas vecinales, el auge de 151 tantos movimientos de ayuda mutua, están marcando la presencia de un signo de Dios 152 en un torbellino de participación sin particularismos pocas veces visto en nuestro país. 153 En la retaguardia hay un pueblo solidario, un pueblo dispuesto a levantarse una y otra 154 vez. Un pueblo que no sólo acude a la necesidad de supervivencia, no sólo ignora las 155 burocracias ineficientes, sino que quiere refundar el vínculo social; un pueblo que está 156 llevando, casi sin saberlo, la virtud de ser socios en la búsqueda del bien común. Un 157 pueblo que quiere conjurar la pobreza del vacío y la desesperanza. Un pueblo con 158 memoria, memoria que no puede reducirse a un mero registro. Aquí está la grandeza de 159 nuestro pueblo. Advierto en nuestro pueblo argentino una fuerte conciencia de su 160 dignidad. Es una conciencia que se ha ido moldeando en hitos significativos. Nuestro 161 pueblo tiene alma, y porque podemos hablar del alma de un pueblo, podemos hablar de 162 una hermenéutica, de una manera de ver la realidad, de una conciencia. Hoy, en medio 163 de los conflictos, este pueblo nos enseña que no hay que hacerle caso a aquellos que 164 pretenden destilar la realidad en ideas, que no nos sirven los intelectuales sin talento, ni 165 los eticistas sin bondad, sino que hay que apelar a lo hondo de nuestra dignidad como 166 pueblo, apelar a nuestra sabiduría, apelar a nuestras reservas culturales. Es una 167 verdadera revolución, no contra un sistema, sino interior; una revolución de memoria y 168 ternura : memoria de las grandes gestas fundantes, heroicas... y memoria de los gestos sencillos que hemos mamado en familia. Ser fieles a nuestra misión es cuidar este 'rescoldo' del corazón, cuidarlo de las cenizas tramposas del olvido o de la presunción de creer que nuestra Patria y nuestra familia no tienen historia o la han comenzado con nosotros. Rescoldo de memoria que condensa, como la brasa al fuego, los valores que nos hacen grandes : el modo de celebrar y defender la vida, de aceptar la muerte, de cuidar la fragilidad de nuestros hermanos más pobres, de abrir las manos solidariamente ante el dolor y la pobreza, de hacer fiesta y de rezar; la ilusión de trabajar juntos y - de nuestras comunes pobrezas - amasar solidaridad.

177 Para que esta fuerza que todos llevamos dentro y que es vínculo y vida se manifieste, es 178 necesario que todos, y especialmente quienes tenemos una alta cuota de poder político, 179 económico o cualquier tipo de influencia, renunciemos a aquellos intereses o abusos de 180 los mismos que pretendan ir más allá del común bien que nos reúne; es necesario que asumamos, con talante austero y con grandeza, la misión que se nos impone. 
182 Nuestro pueblo, que sabe organizarse espontánea y naturalmente en la comunidad 183 nacional protagonista de este nuevo vínculo social, pide un lugar de consulta, control y 184 creativa participación en todos los ámbitos de la vida social que le incumben. Los 185 dirigentes debemos acompañar esta vitalidad del nuevo vínculo. Potenciarlo y 186 protegerlo puede llegar a ser nuestra principal misión. No resignemos nuestras ideas, 187 utopías, propiedades ni derechos, sino renunciemos solamente a la pretensión de que 188 sean únicos o absolutos. Todos estamos convidados a este encuentro, a realizar y 189 compartir este fermento nuevo que - a la vez - es memoria revivificante de nuestra 190 mejor historia de sacrificio solidario, de lucha libertaria y de integración social.

$191 \mathrm{~V}$

192 Aquel Mayo histórico, lleno de vaivenes e intereses en juego, supo congregar a todo el 193 pueblo virreinal a una decisión común, iniciadora de otra historia. Quizás necesitemos 194 sentir que la Patria de todos es un nuevo Cabildo, una gran mesa de comunión donde, 195 no ya la nostalgia desolada, sino el reconocimiento esperanzador, nos impulse a 196 proclamar como los discípulos de Emaús: "¿Acaso no ardía nuestro corazón mientras 197 nos hablaba en el camino y nos explicaba las Escrituras?" Que arda nuestro corazón en 198 deseos de vivir y crecer en este hogar propio sea la petición que acompañe esta acción 199 de gracias al Padre y el compromiso de cumplir con su Palabra; convenciéndonos una 200 vez más que el todo es superior a la parte, el tiempo superior al espacio, la realidad es 201 superior a la idea y la unidad es superior al conflicto.

202 Jorge Mario Bergoglio, s.j.

20325 de mayo de 1999 
1 Homilía de Tedeum del 25 de mayo de 2000

2

Enseguida, Jesús se dirigió a una ciudad llamada Naím, acompañado de sus discípulos y de una gran multitud. Justamente cuando se acercaba a la puerta de la ciudad, llevaban a enterrar al hijo único de una mujer viuda, y mucha gente del lugar la acompañaba. Al verla, el Señor se conmovió y le dijo: "No llores". Después se acercó y tocó el féretro. Los que lo llevaban se detuvieron y Jesús dijo: "Joven yo te lo ordeno, levántate". El muerto se incorporó y empezó a hablar. Y Jesús se lo entregó a su madre. Todos quedaron sobrecogidos de temor y alababan a Dios, diciendo: "Un gran profeta ha aparecido en medio de nosotros y Dios ha visitado a su Pueblo". El rumor de lo que Jesús acababa de hacer se difundió por toda la Judea y en toda la región vecina. (Evangelio según San Lucas, 7:11-17)

Desde el llamado del Santo Padre a la celebración del Gran Jubileo, este año, para todo cristiano, ha quedado preñado de esperanza. En el 2000 no vivimos un convencional aniversario sino que celebramos la permanencia del mismo Cristo entre nosotros. Hacemos memoria de su gracia transformadora de la humanidad y también hacemos memoria de la resistencia de nuestra naturaleza. La primera, para agradecer y alabar; la segunda, para reconocer y pedir perdón. A todo esto lo llamamos conversión.

Como dice el Evangelio, "un gran profeta ha aparecido en medio de nosotros y Dios ha visitado a su pueblo" (Lc. 7:16 b). Hay júbilo porque Dios está con nosotros y entre nosotros y, a pesar de la resistencia al amor que es el pecado, El nos ofrece el gozo de sentirnos redimidos, de sentirnos llamados a amar de nuevo, como El nos enseñó. Se nos invita a comenzar un tiempo nuevo: es el recomenzar de Cristo quien, a pesar de "conocer lo que hay en el interior del hombre", sigue confiando en el don de la libertad, en la chispa de amor que el Espíritu infunde en nuestros corazones.

Estoy seguro de que el anhelo de todos los argentinos es poder llegar a este nuevo aniversario de Mayo con la misma esperanza jubilar que hoy alienta a millones en el mundo. Júbilo de Cristo encarnado en la fe y en el dolor de nuestro pueblo, esperanza de revivir aquellos aires heroicos que, más allá de los errores e intereses contradictorios, supieron conjugarse para comenzar la aventura de una nueva Nación. La esperanza ahonda el alma y la pacifica, pues, al abrir -magnánimos- el corazón, confiados en la promesa hecha, en la palabra dada, los hombres se liberan de las suspicacias y pesimismos de su razón inmediata e incluso del peso de ciertas evidencias. El que vive de lo que espera muestra la dignidad de ser imagen y semejanza del Padre. Su alegría se hace gratuita, no depende del éxito ni de los resultados más inmediatos.

Cimentada así la profunda alegría que perdura como paz, el júbilo es el que -en definitiva- construye los vínculos más allá de las diferencias y los condicionamientos. Los argentinos queremos renacer en la promesa de los mayores que comenzaron la patria, y para esto necesitamos imperiosamente de la esperanza que haga brotar la alegría, pues de ella surgirán los vínculos que derribarán miedos e inseguridades, distancias que hoy parecen insalvables. Esperanza para la alegría, alegría para el vínculo.

Para esta misma fecha, hace un año, destaqué la necesidad de refundar el vínculo social entre los argentinos, un vínculo esperanzador: Un vínculo que acerque la dolorosa brecha entre los que tienen más y los que tienen menos. Que acerque a los jóvenes que no encuentran su propio proyecto social. Un vínculo que nos reavive el 
amor a una niñez con frecuencia despreciada y empobrecida. Que nos alarme frente a cada persona que pierde su trabajo. Que nos haga solidarios e integradores para con los inmigrantes desposeídos y de buena voluntad, que llegan y deben seguir llegando. Un vínculo que nos haga especialmente cuidadosos de los ancianos que han desgastado su vida por nosotros y hoy merecen celebrar y recuperar sus puestos de sabios y maestros transmitiéndonos esperanza.

Refundar con esperanza nuestros vínculos sociales: esto no es un frío postulado eticista y racionalista. No se trata de una nueva utopía irrealizable ni mucho menos de un pragmatismo desafectado y expoliador. Es la necesidad imperiosa de convivir para construir juntos el bien común posible, el de una comunidad que resigna intereses particulares para poder compartir con justicia sus bienes, sus intereses, su vida social en paz. Tampoco se trata solamente de una gestión administrativa o técnica, de un plan, sino que es la convicción constante que se expresa en gestos, en el acercamiento personal, en un sello distintivo, donde se exprese esta voluntad de cambiar nuestra manera de vincularnos amasando, en esperanza, una nueva cultura del encuentro, de la projimidad; donde el privilegio no sea ya un poder inexpugnable e irreductible, donde la explotación y el abuso no sean más una manera habitual de sobrevivir. En esta línea de fomentar un acercamiento, una cultura de esperanza que cree nuevos vínculos, los invito a ganar voluntades, a serenar y convencer.

Ya vimos en el Evangelio a nuestro Señor Jesucristo iniciando el vínculo esperanzado de un nuevo pueblo. La imagen de Jesús resucitando al hijo de la viuda es una imagen fuerte -con la fuerza del drama, no de la tragedia- y hay en ella muerte y vida resucitada. No se disfraza el dolor ni se atenúa la esperanza. La clave está en ese Jesús que se conmueve, que se acerca, que toca el dolor y la muerte y los convierte en vida nueva. No dejó que aquel luto del joven muerto aplastara la esperanza: "No llores", le dijo a la madre y tocó el dolor. A veces me pregunto si no marchamos, en ciertas circunstancias de la vida de nuestra sociedad, como en un triste cortejo, y si no insistimos en ponerle una lápida a nuestra búsqueda como si camináramos a un destino inexorable, enhebrado de imposibles; y nos conformamos con pequeñas ilusiones desprovistas de esperanza.

Debemos reconocer, con humildad, que el sistema ha caído en un amplio cono de sombra: la sombra de la desconfianza, y que algunas promesas y enunciados suenan a cortejo fúnebre: todos consuelan a los deudos pero nadie levanta al muerto. ¡Levántate! es el llamado de Cristo en su Jubileo. ¡Levántate Argentina! como nos dijo en su última visita el Santo Padre, como lo soñaron y realizaron nuestros próceres fundadores. Pero hasta no reconocer nuestras dobles intenciones no habrá confianza ni paz. Hasta que no se efectivice nuestra conversión no tendremos alegría y gozo. Porque la ambición desmedida, ya sea de poder, de dinero o de popularidad, sólo expresa un gran vacío interior. Quienes están vacíos no trasmiten paz, gozo y esperanza sino sospecha. No crean vínculos.

¡Toca, Señor, a nuestra Argentina aún joven, no replegada sobre sí sino abierta a sus vecinos. Muéstranos tu gesto de amor que nos haga perder el miedo! Y, nosotros, animémosnos a tocar: a tocar al marginado del sistema, viendo en él a hombres y mujeres que son mucho más que votantes potenciales. En el marco de las Instituciones republicanas demos poder y apoyo a aquellas organizaciones comunitarias que estrechan las manos y hacen participar, que privilegian la intimidad, la fraternidad, la lealtad a los principios y objetivos como una nueva "productividad". Así los jóvenes recuperarán horizontes concretos, descubrirán los 
futuros posibles dejando de lado enunciados vacíos, que ahondan las propias vaciedades.

Para esto hay que tocar al doliente, al que todos creen muerto. Hay que darle valor: "Joven, te lo mando, levántate". Para esto, como Cristo, hay que atreverse a renunciar al poder que acapara y enceguece, y aceptar ejercer la autoridad que sirve y acompaña. Unos pocos tienen el poder de las finanzas y la técnica; otros ejercen el poder del Estado, pero sólo una comunidad activa, que se vuelve solidaria y trabaja mancomunada puede, en su creativa diversidad, impulsar la barca del bien común, ser la custodia de la ley y la convivencia.

Como Cristo Redentor, que no tomó la gloria del joven revivido para sí, sino que lo devolvió a su ámbito, a su madre, así quienes detentamos alguna autoridad sirvamos a la comunidad. Cedamos el protagonismo a la comunidad, apoyando y sosteniendo a quienes se organizan en pos de sus fines. Así se quebrarán las barreras de la incomunicación que, paradójicamente, existe en este mundo supercomunicado. Así se acerca la cosa pública a sus verdaderos protagonistas, que ya no quieren hipotecar su suerte a sábanas de representantes desconocidos.

Creemos que estas iniciativas comunitarias son los signos esperanzadores de una alegría participativa. Aquí se gesta una verdadera revolución interior y -a la veztransformación social que escapa a las "macromanipulaciones" de los sistemas y estructuras extraños al ser genuino del pueblo. Estas iniciativas brindan una inmejorable salida frente al suicidio social que provoca toda filosofía y técnica que expulsa la mano de obra, que margina la ternura del afecto familiar, que negocia los valores propios de la dignidad del hombre. Sólo hace falta la audaz y esperanzadora iniciativa de ceder terreno, de renunciar al protagonismo fútil; la iniciativa de dejar las luchas intestinas desgastantes, el plus de insacibilidad de poder. Podemos, sí podemos, no tenemos que dudar, podemos devolver una joven Argentina a nuestros mayores, a nuestros ancianos: esos hombres y mujeres que hoy, con tanta frecuencia, llegan al ocaso de su vida y no pueden tener "júbilo" porque han sido defraudados y se encuentran al borde del escepticismo. Con ellos tenemos una deuda, no sólo de justicia sino también de supervivencia para nuestros jóvenes, pues ellos son rescoldo de memoria. Ojalá nos animemos a devolverles una esperanzada Argentina, como el joven devuelto a su madre, para que ellos animen con su sonrisa de esperanza la vida de los jóvenes hoy entristecidos. Y entonces veremos que el que creíamos muerto se levantará, como leímos en el Evangelio, y comenzará a hablar. Entonces comprenderemos que "la esperanza no defrauda" (Rom. 5:5). 


\section{Homilía de Tedeum del 25 de mayo de 2001}

"Entonces la madre de los hijos de Zebedeo se acercó a Jesús, junto con sus hijos y se postró ante él para pedirle algo. "¿Qué quieres?, le preguntó Jesús. Ella le dijo: "Manda que mis dos hijos se sienten en tu Reino, uno a tu derecha y el otro a tu izquierda". "No saben lo que piden", respondió Jesús. "¿Pueden beber el cáliz que yo beberé?. "Podemos", le respondieron. "Está bien, les dijo Jesús, ustedes beberán mi cáliz. En cuanto a sentarse a mi derecha o a mi izquierda, no me toca a mí concederlo, sino que esos puestos son para quienes se los ha destinado mi Padre.

Al oír esto, los otros diez se indignaron contra los dos hermanos. Pero Jesús los llamó y les dijo: "Ustedes saben que los jefes de las naciones dominan sobre ellas y los poderosos les hacen sentir su autoridad. Entre Ustedes no debe suceder así. Al contrario, el que quiera ser grande, que se haga servidor de Ustedes; y el que quiera ser el primero que se haga su esclavo: como el Hijo del hombre, que no vino para ser servido, sino para servir y dar su vida en rescate por una multitud". (Mt. 20: 20-28)

1.- Queda claro que no es cosa novedosa ni comienza en nuestra época ese primer impulso ante quien tiene poder: el de obtener algún favor. Acabamos de escuchar en el Evangelio cómo la madre de Juan y de Santiago le pidió a Jesús que tuviera en cuenta a sus hijos. Lo que sí resulta novedoso es la respuesta del Señor: "No saben lo que piden. ¿Pueden beber el cáliz que yo beberé?". ¿De qué cáliz se trata? El Señor habla del cáliz del servicio y de dar la vida hasta el punto de derramar la sangre por los que se ama. Y más novedoso aún resulta el cambio de actitud que logró el Señor en los apóstoles, pues verdaderamente cambiaron, no su ansia de grandeza sino el camino para encontrarla y pasaron de la veleidad de los pequeños acomodos al deseo grande del verdadero poder: el poder servir por amor. En este día de la Patria, quiero detenerme en la enseñanza del Señor: "el que quiera ser grande que se haga servidor de Ustedes; y el que quiera ser el primero que se haga su esclavo: como el Hijo del Hombre, que no vino para ser servido sino para servir..."(Mt 20,26-28)

$\underline{\text { Servicio, }}$, palabra venerada y manipulada a la vez; palabra que expresa una de las riquezas más originales del camino andado por la humanidad en Jesucristo, que no vino a ser servido sino a servir, que se abajó para lavarnos los pies... El servicio es la inclinación ante la necesidad del otro, a quien -al inclinarme- descubro, en su necesidad, como mi hermano. Es el rechazo de la indiferencia y del egoísmo utilitario. Es hacer por los otros y para los otros. Servicio, palabra que suscita el anhelo de un nuevo vínculo social dejándonos servir por el Señor, para que luego, a través de nuestras manos, su amor divino descienda y construya una nueva humanidad, un nuevo modo de vida. $\underline{\text { Servicio, }}$ palabra grabada a fuego en lo hondo del corazón de nuestro pueblo. De esa reserva espiritual heredada de nuestros abuelos brotan nuestra dignidad, nuestra capacidad de trabajo duro y solidario, nuestra serenidad aguantadora y esperanzada. Del servicio como valor central, surgen, si uno sabe remover en el rescoldo de nuestro corazón común (porque los pueblos tienen un corazón común) aquellas grandes actitudes que mantienen integrada a nuestra sociedad. Me pregunto si comprendemos hoy, mejor que aquellos incipientes discípulos, que se nos ha dado una maravillosa oportunidad, un don que sólo Dios puede dar: el de darnos y darnos por entero.

2.- El servicio no es un mero compromiso ético, ni un voluntariado del ocio sobrante, ni un postulado utópico... Puesto que nuestra vida es un don, servir es ser fieles a lo que 
somos: se trata de esa íntima capacidad de dar lo que se es, de amar hasta el extremo de los propios límites... o, como nos enseñaba con su ejemplo la Madre Teresa, servir es "amar hasta que duela". Las palabras del Evangelio no van dirigidas sólo al creyente y al practicante. Alcanzan a toda autoridad tanto eclesial como política, ya que sacan a la luz el verdadero sentido del poder. Se trata de una revolución basada en el nuevo vínculo social del servicio. El poder es servicio. El poder sólo tiene sentido si está al servicio del bien común. Para el gozo egoísta de la vida no es necesario tener mucho poder. A esta luz comprendemos que una sociedad auténticamente humana, y por tanto también política, no lo será desde el minimalismo que afirma "convivir para sobrevivir" ni tampoco desde un mero "consenso de intereses diversos" con fines economicistas. Aunque todo esté contemplado y tenga su lugar en la siempre ambigua realidad de los hombres, la sociedad será auténtica sólo desde lo alto..., desde lo mejor de sí, desde la entrega desinteresada de los unos por los otros. Cuando emprendemos el camino del servicio renace en nosotros la confianza, se enciende el deseo de heroísmo, se descubre la propia grandeza.

3.- Teniendo en cuenta esta realidad resulta obvio que dormirse en los contubernios de poder, empeñarse en negar las necesidades, no enfrentar las contradicciones, acentuar los odios internos, no hace sino prolongar una agonía de mediocridades. Y aunque, admitiendo las dificultades que se nos imponen desde fuera más allá de nuestra voluntad, siempre seremos nosotros los últimos responsables de nuestro propio sometimiento y postergación. Mientras algunos pretenden sacar rédito acentuando las divisiones y desviando el foco de atención de los grandes desafíos, una vez más desde las reservas más profundas de nuestro pueblo surge la valoración intuitiva del llamado evangélico que hoy hemos escuchado: ¡beber el cáliz del servicio! Nuestro pueblo lo bebe diariamente en el servicio de millones de personas que silenciosamente ponen el cuerpo al trabajo o a la búsqueda de él y no a la especulación, en el servicio de los que sostienen la convivencia y solidaridad callada y no los absurdos fantasmas de xenofobia propios de minorías ideológicas agitadoras de conflictos, en el servicio de los que sufriendo la globalización de la pobreza- no han dejado de igualarse en la solidaridad de organizaciones comunitarias y manifestaciones culturales, espontáneas y creativas. Todos estos, mujeres y hombres de nuestro pueblo, que rechazan la desesperanza y se rebelan contra aquellas mediocridades, quieren decirle no a la anomia, no al sinsentido y a la superficialidad fraudesca (cuando no farandulera) que alienta el consumismo. Y no, en fin, a quienes necesitan un pueblo pesimista y agobiado de malas noticias para obtener beneficios de su dolor.

4.- Desde la disposición al servicio, sacudidos por la miseria y desprotección, desgarrados por la violencia y las drogas, bombardeados por la presión del escapismo de todo tipo y forma, queremos renacer de nuestras propias contradicciones. Aceptamos el cáliz doloroso y sacamos nuestras mejores reservas como pueblo con poca prensa y menos propaganda. En cada esfuerzo solidario individual y comunitario de una extensa red de organizaciones sociales, en cada investigador y estudioso que apuesta a la búsqueda de la verdad (aunque otros relativicen o callen), en cada docente y maestro que sobrevive a la adversidad, en cada productor que sigue apostando al trabajo, en cada joven que estudia, trabaja y brinda su compromiso formando una familia nueva. En los más pobres y en todos los que trabajan o fatigosamente buscan trabajo, que no se dejan arrastrar por la marginación destructiva ni por la tentación de la violencia organizada sino que, silenciosamente y con la entrega que sólo concede la fe, siguen amando a su tierra. Ellos han probado un cáliz que, en la entrega y el servicio, se ha hecho bálsamo y 
esperanza. En ellos se manifiesta la gran reserva cultural y moral de nuestro pueblo. Ellos son los que escuchan la palabra, los que se ahorran los aplausos rituales, los que de verdad se hacen eco y comprenden que no se habla para otros.

5.- En este día patrio quisiera que nos planteáramos la pregunta: ¿estamos dispuestos a beber el "cáliz" de los "cristos silenciosos" de nuestro pueblo? ¿Beber de la copa de los sinsabores y dolores de nuestros límites y miserias como nación pero -a la vezreconocer allí mismo el vino alegre del con-formarnos al modo de ser del pueblo al que pertenecemos? ¿Animarnos a servir sin simulaciones ni mediocridades para sentirnos dignos y satisfechos de ser lo que somos?

Se nos invita a beber del cáliz del trabajo duro y solidario que, desde el principio, conoció el hombre de nuestra tierra. Trabajo que mestizó, a pesar de muchos desencuentros, a aborígenes y españoles. Trabajo que costó sangre para la independencia, que forjó la admiración del mundo en la dedicación de educadores, investigadores y científicos. Trabajo que despertó la conciencia social de millones de postergados, como avanzada en el continente, y que también probaron y prueban nuestras artes y letras cuando cantan nuestra a veces tímida alegría de ser argentinos. El cáliz del trabajo solidario en el servicio es la respuesta más genuina a la incertidumbre de un país lleno de potencialidades que no se realizan o se postergan una y otra vez, indefinidamente, deteniendo su derrotero de grandeza. Es la respuesta a la incertidumbre de un país dañado por los privilegios, por los que utilizan el poder en su provecho a cuenta de la legitimidad representativa, por quienes exigen sacrificios incalculables, escondidos en sus burbujas de abundancia, mientras evaden su responsabilidad social y lavan las riquezas que el esfuerzo de todos producen; por los que dicen escuchar y no escuchan, por los que aplauden ritualmente sin hacerse eco, por los que creen que se habla para otros. Las reglas de juego de la realidad global de estos tiempos son un cáliz amargo, pero esto debe redoblar la entrega y el esfuerzo ético de una dirigencia que no tiene derecho a exigir más a los de abajo si el sacrificio no baja desde arriba: "...el que quiera ser grande , que se haga servidor de Ustedes". "Servir a" imponiéndose al "Servirse de".

6.- No menos que el trabajo solidario como servicio hoy también es primordial sacar, del rescoldo de la amargura, la brasa cálida de la serenidad esperanzada. En efecto, desde lo profundo de nuestras reservas, en las vivencias de fe comunitaria de nuestra historia y sin dejar de verse afectada por nuestras miserias, deben volver a nuestra memoria tantas formas culturales de religiosidad y arte, de organizaciones comunitarias y de logros individuales o grupales. Porque en el rescate de nuestras reservas, de nuestro buen ser heredado, está la piedra de arranque del futuro.

Así como no podemos prometer amor hacia adelante sin haberlo recibido, no podemos tampoco sentirnos confiados en ser argentinos si no rescatamos los bienes del pasado. Y esto sin resentimientos estériles, sin revisionismos simplistas, sin escrutar pequeñeces perdiendo de vista las grandezas que ayudan a construir los valores referenciales que necesita toda sociedad. No olvidemos que cuando una sociedad se complace en burlarse de su intimidad y permite que se banalice su capacidad creativa, entonces se opaca y la posibilidad de ser libres se desgasta por una superficialidad que ahoga. Y cuando dichas actitudes son propuestas a una comunidad cuyas necesidades básicas están seriamente agredidas, surgen entonces las lógicas reacciones de violencia, adicciones y la marginalidad cultural y social. 
140 Rescatar nuestra memoria significa, por el contrario, contemplar los brotes de un alma 141 que se resiste a su opresión. En nuestro pueblo existen manifestaciones populares 142 artísticas donde anida el sentimiento y la humanización; hay una vuelta a la fe y a la 143 búsqueda espiritual ante el fracaso del materialismo, el cientificismo y las ideologías; 144 las organizaciones espontáneas de la comunidad son formas vigentes de socialización y 145 búsqueda del bien común. Estas propuestas populares, emergentes de nuestra reserva 146 cultural, trascienden los sectarismos, los partidismos y los intereses mezquinos. Ahora 147 también, como en la Argentina de ayer y de siempre, se vislumbran objetivos comunes 148 que solidarizan a aborígenes y españoles, a criollos e inmigrantes, y a todos los credos, 149 en pos del bien común.

150 A esto llamamos serenidad porque construye con el bien solidario y la alegría creativa, 151 esperanzadora; porque apunta más allá de los intereses y los logros; es el despunte del 152 amor como vínculo social privilegiado, que se gusta por sí mismo. Serenidad que nos 153 aleja de la violencia institucionalizada y es el antídoto contra la violencia desorganizada 154 o promovida. Y será esa misma serenidad la que nos animará a defender unánimes 155 nuestros derechos, sobre todo los más urgentes: el derecho a la vida, el derecho a recibir 156 educación y atención de salud (que ninguna política puede postergar) y la irrenunciable 157 responsabilidad de fortalecer a los ancianos, ayudar a promover a la familia (sin la cual 158 no hay humanización ni ley) y a los niños, hoy alevosamente postergados y 159 despreciados.

160 7.- En este día de la patria, el Señor nos convoca a dejar todo servilismo para entrar en 161 el territorio de la servicialidad, ese espacio que se extiende hasta donde llega nuestra 162 preocupación por el bien común y que es la patria verdadera. Fuera del espacio de la 163 servicialidad no hay patria sino una tierra devastada por luchas de intereses sin rostro.

164 En este día de la Patria, el Señor nos anima a no tener miedo de beber el cáliz del 165 servicio. Si el servicio nos iguala, desalojando falsas superioridades, si el servicio 166 achica distancias egoístas y nos aproxima -nos hace prójimos- no tengamos miedo: el 167 servicio nos dignifica, devolviéndonos esa dignidad que clama por su lugar, por su 168 estatura y sus necesidades.

169 En este día de la Patria nuestro pueblo nos reclama y nos pide que no nos cansemos de 170 servir, que sólo así ese nuevo vínculo social que anhelamos, será una realidad. Ya 171 hemos probado hasta el hartazgo cómo se desgasta nuestra convivencia por el abuso 172 opresor de algún sector sobre otro, con los internismos que dan la espalda a los grandes 173 problemas, con equívocas lealtades, con los enfrentamientos sectoriales o ideológicos 174 más o menos violentos. Estas dialécticas del enfrentamiento llevan a la disolución 175 nacional, anulan el encuentro y la projimidad. El servicio nos invita a converger, a 176 madurar, a crear -en definitiva- una nueva dinámica social: la de la comunión en las 177 diferencias cuyo fruto es la serenidad en la justicia y la paz. Plural comunión de todos 178 los talentos y todos los esfuerzos sin importar su origen. Comunión de todos los que se 179 animan a mirar a los demás en su dignidad más profunda.

180 Ésta es la propuesta evangélica que hoy planteamos en la conmemoración de la fecha 181 que es memoria viva de nuestras más hondas reservas morales como pueblo; propuesta 182 que será, si la asumimos, el mejor homenaje a nuestros próceres y a nosotros mismos.

183 Card. Jorge Mario Bergoglio s.j. 25 de mayo de 2001 


\section{$1 \quad$ Homilía Tedeum 25 de mayo 2002}

"Jesús entró en Jericó y atravesaba la ciudad. Allí vivía un hombre muy rico llamado Zaqueo, era jefe de los publicanos.

El quería ver quién era Jesús, pero no podía a causa de la multitud, porque era de baja estatura. Entonces se adelantó y subió a un sicómoro para poder verlo, porque iba a pasar por allí. Al llegar a ese lugar, Jesús miró hacia arriba y le dijo: Zaqueo, baja pronto, porque hoy tengo que alojarme en tu casa. Zaqueo bajó rápidamente y lo recibió con alegría.. Al ver esto, todos murmuraban, diciendo: Se ha ido a alojar en casa de un pecador;. Pero Zaqueo dijo resueltamente al Señor: Señor, voy a dar la mitad de mis bienes a los pobres, y si he perjudicado a alguien, le daré cuatro veces más;. Y Jesús le dijo: Hoy ha llegado la salvación a esta casa, ya que también este hombre es un hijo de Abraham, porque el Hijo del hombre vino a buscar y a salvar lo que estaba

(Del Evangelio de Nuestro Señor Jesucristo según San Lucas 19,1-10) perdido."

14 Quizás como pocas veces en nuestra historia, esta sociedad malherida aguarda una nueva llegada del Señor. Aguarda la entrada sanadora y reconciliante de Aquél que es Camino, Verdad y Vida. Tenemos razones para esperar. No olvidamos que su paso y su presencia salvífica han sido una constante en nuestra historia. Descubrimos la maravillosa huella de su obra creadora en una naturaleza de riqueza incomparable. La generosidad divina también se ha reflejado en el testimonio de vida de entrega y sacrificio de nuestros padres y próceres, del mismo modo que en millones de rostros humildes y creyentes, hermanos nuestros, protagonistas anónimos del trabajo y las luchas heroicas, encarnación de la silenciosa epopeya del Espíritu que funda pueblos.

Sin embargo, vivimos muy lejos de la gratitud que merecería tanto don recibido. ¿Qué impide ver esta llegada del Señor? ¿Qué torna imposible el; gustar y ver qué bueno es el Señor; (Sal. 34,9) ante tanta prodigalidad en la tierra y en los hombres? ¿Qué traba las posibilidades de aprovechar en nuestra Nación, el encuentro pleno entre el Señor, sus dones, y nosotros? Como en la Jerusalén de entonces, cuando Jesús atravesaba la ciudad y aquel hombre llamado Zaqueo no lograba verlo entre tanta muchedumbre, algo nos impide ver y sentir su presencia. En la escena evangélica se nos da la clave en términos de altura y de abajamiento. De altura, porque Zaqueo se deja ganar el corazón por el deseo de ver a Jesús y, como era pequeño de estatura, se adelanta y trepa a un sicómoro. Ningún talento, ninguna riqueza puede reemplazar una chatura moral o en todo caso, si el problema no es moral- no hay salida para una mirada baja, sin esperanza, resignada a sus límites, carente de creatividad.

En esta tierra bendita, nuestras culpas parecen haber achatado nuestras miradas. Un triste pacto interior se ha fraguado en el corazón de muchos de los destinados a defender nuestros intereses, con consecuencias estremecedoras: la culpa de sus trampas acucia con su herida y, en vez de pedir la cura, persisten y se refugian en la acumulación de poder, en el reforzamiento de los hilos de una telaraña que impide ver la realidad cada vez más dolorosa. Así el sufrimiento ajeno y la destrucción que provocan tales juegos de los adictos al poder y a las riquezas, resultan para ellos mismos apenas piezas de un tablero, números, estadísticas y variables de una oficina de planeamiento. A medida que tal destrucción crece, se buscan argumentos para justificar y demandar más sacrificios escudándose en la repetida frase; no queda otra salida; pretexto que sirve para narcotizar sus conciencias. Tal chatura espiritual y ética no sobreviviría sin el refuerzo de aquellos que padecen otra vieja enfermedad del corazón: la incapacidad de sentir culpa. Los ambiciosos escaladores, que tras sus diplomas internacionales y su lenguaje técnico, por 
lo demás tan fácilmente intercambiable, disfrazan sus saberes precarios y su casi 49 inexistente humanidad.

50 Como a Zaqueo puede hacérsenos consciente nuestra dificultad para vivir con altura espiritual: sentir el peso del tiempo malgastado, de las oportunidades perdidas, y surgirnos dentro un rechazo a esa impotencia de llevar adelante nuestro destino, encerrados en nuestras propias contradicciones. Ciertamente, es habitual que, frente a la impotencia y los límites, nos inclinemos a la fácil respuesta de delegar en otros toda la representatividad e interés por nosotros mismos. Como si el bien común fuera una ciencia ajena, como si la política -a su vez- no fuera una alta y delicada forma de ejercer la justicia y la caridad. Cortedad de miras para ver el paso de Dios entre nosotros, para sentirnos gratificados y dignos de tantos dones, y no tener escrúpulos en hacerlos valer sin renunciar a nuestra histórica vocación de apertura no invasiva a otros pueblos hermanos.

Como nosotros también Zaqueo sufría esa cortedad de miras. Sin embargo sucede el milagro: el personaje evangélico se eleva sobre su mediocridad y encuentra la altura donde subirse. Porque del dolor y de los límites propios es de donde mejor se aprende a crecer y de nuestros mismos males es desde donde nos surge una honda pregunta: ¿Hemos vivido suficiente dolor para decidirnos a romper viejos esquemas, renunciar a actitudes necias tan arraigadas y dar rienda suelta a nuestras verdaderas potencialidades? ¿No estamos ante la oportunidad histórica de revisar antiguos y arraigados males que nunca terminamos de plantear, y trabajar juntos? ¿Hace falta que más sangre corra al río, para que nuestro orgullo herido y fracasado reconozca su derrota?

Zaqueo no optó por la resignación frente a sus dificultades, no cedió su oportunidad a la impotencia, se adelantó, buscó la altura desde donde ver mejor, y se dejó mirar por El Señor. Sí, dejarse mirar por el Señor, dejarse impactar por el dolor propio y el de los demás; dejar que el fracaso y la pobreza nos quiten los prejuicios, los ideologismos, las modas que insensibilizan, y que; de ese modo- podamos sentir el llamado: Zaqueo baja pronto. Esta es la segunda clave de este pasaje evangélico: Zaqueo responde a un Jesús que lo llama a abajarse. Bajarse de sus autosuficiencias, bajarse del personaje inventado por su riqueza, bajarse de la trampa montada sobre sus pobres complejos. En efecto, ninguna altura espiritual, ningún proyecto de grandes esperanzas, puede hacerse real si no se construye y se sostiene desde abajo: desde el abajamiento de los propios intereses, desde el abajamiento al trabajo paciente y cotidiano que aniquila toda soberbia.

Hoy como nunca, cuando el peligro de la disolución nacional está a nuestras puertas, no podemos permitir que nos arrastre la inercia, que nos esterilicen nuestras impotencias o que nos amedrenten las amenazas. Tratemos de ubicarnos allí donde mejor podamos enfrentar la mirada de Dios en nuestras conciencias, hermanarnos cara a cara, reconociendo nuestros límites y nuestras posibilidades. No retornemos a la soberbia de la división centenaria entre los intereses centralistas, que viven de la especulación monetaria y financiera, como antes del puerto, y la necesidad imperiosa del estímulo y promoción de un interior condenado ahora a la curiosidad turística. Que tampoco nos empuje la soberbia del internismo faccioso, el más cruel de los deportes nacionales, en el cual, en vez de enriquecernos con la confrontación de las diferencias, la regla de oro consiste en destruir implacablemente hasta lo mejor de las propuestas y logros de los oponentes. Que no nos corten caminos las calculadoras intransigencias (en nombre de 
coherencias que no son tales). Que no sigamos revolcándonos en el triste espectáculo de quienes ya no saben cómo mentir y contradecirse para mantener sus privilegios, su rapacidad y sus cuotas de ganancia mal habidas, mientras perdemos nuestras oportunidades históricas, y nos encerramos en un callejón sin salida. Como Zaqueo hay que animarse a sentir el llamado a bajar: bajar al trabajo paciente y constante, sin pretensiones posesivas sino con la urgencia de la solidaridad.

Hemos vivido mucho de ficciones, creyendo estar en los primeros mundos, nos atrajo el becerro de oro de la estabilidad consumista y viajera de algunos, a costa del empobrecimiento de millones. Cuando oscuras complicidades de dentro y fuera, se convierten en coartadas de actitudes irresponsables que no vacilan en llevar las cosas al límite sin reparar en daños: negocios sospechosos, lavados que eluden obligaciones, compromisos sectoriales y partidarios que impiden una acción soberana, operativos de desinformación que confunden, desestabilizan y presionan hacia el caos; cuando sucede esto de poco nos sirve la tentación ilusoria de exigir chivos expiatorios en aras del supuesto surgimiento de una clase mejor, pura y mágica. Sería subirse a otra ilusión. Debemos reconocer con dolor que, entre los propios y los opuestos hay muchos Zaqueos, con distintos títulos y funciones; Zaqueos que intercambian papeles en un escenario de avaricia casi autoritaria, a veces con disfraces legítimos.

Lo mejor es dejar que el Zaqueo que hay dentro de cada uno de nosotros se deje mirar por el Señor, y acepte la invitación a bajar. Este llamado del Evangelio es memoria y camino de esperanza. Aquel que busca y se deja alcanzar por lo sublime da lugar a una alegría nueva, a una posibilidad de redención. Y Zaqueo se redime, accede alegre a la invitación del único que nos puede reconciliar, Dios mismo. Accede a sentarse a la mesa de todos, a la de la amistad social. Nadie le pidió a aquel publicano que fuera lo que no podía ser, sino que simplemente se bajara del árbol. Se le pide que se avenga a la Ley de ser uno más, de ser hermano y compatriota, que cumpla la ley.

Esto hay que lograr: hacer cumplir la ley, que nuestro sistema funcione, que el banquete al que se nos convoca en el Evangelio sea ese lugar de encuentro y convivencia, de trabajo y celebración que queremos, y no un café al paso; para los intereses; golondrina; del mundo; esos que llegan, extraen y parten. La ley es la condición infranqueable de la justicia, de la solidaridad y de la política, y ella nos cuida, al bajar del árbol, de no caer en la tentación de la violencia, del caos, del revanchismo. Asumamos el dolor de tanta sangre vertida inútilmente en nuestra historia. Abramos los ojos a tiempo: una sorda guerra se está librando en nuestras calles, la peor de todas, la de los enemigos que conviven y no se ven entre sí, pues sus intereses se entrecruzan manejados por sórdidas organizaciones delincuenciales y sólo Dios sabe qué más, aprovechando el desamparo social, la decadencia de la autoridad, el vacío legal y la impunidad.

No es el momento de tener miedo y vergüenza de nosotros mismos, todos somos un poco Zaqueo, y todos tenemos enormes talentos y valores. Miramos con nostalgia las riquezas naturales, la brillantez de tantos compatriotas dispersos, la silenciosa e increíble resistencia de un pueblo humilde que defiende sus reservas y se niega a ceder su fe y sus convicciones, que lucha contra el desgaste. Ahora o nunca, busquemos la refundación de nuestro vínculo social, como tantas veces lo reclamamos con toda la sociedad y, como este publicano arrepentido y feliz, demos rienda suelta a nuestra grandeza: la grandeza de dar y darnos. La gran exigencia es la renuncia a querer tener toda la razón; a mantener los privilegios; a la vida y la renta fácil, a seguir siendo 
140 necios, enanos en el espíritu. Como en el llamado evangélico, en numerosas 141 oportunidades nos hemos dejado visitar por Dios. Allí lo grande y sublime ha surgido de 142 nosotros. Hay en toda la sociedad un anhelo ya propuesto, insoslayable, de participar y 143 controlar su propia representación, como aquel día que hoy rememoramos en que la 144 comuna se constituyó en Cabildo.

145 Además del subirse para ver a Jesús y abajarse luego para seguir su invitación hay una 146 tercera clave en el texto evangélico: el dar, el darse reparando el mal cometido. Zaqueo 147 se anima a devolver lo mal habido y a compartir. Como el Zaqueo convertido, este 148 pueblo, siente el deseo de dar la mitad; y devolver el cuádruplo. Quiere rescatar del 149 fondo de su alma el trabajo y la solidaridad generosa, la lucha igualitaria y la conquista 150 social, la creatividad y la celebración. Sabemos bien que este pueblo podrá aceptar 151 humillaciones, pero no la mentira de ser juzgado culpable por no reconocer la exclusión 152 de veinte millones de hermanos con hambre y con la dignidad pisoteada. Si Zaqueo, 153 antes de dejarse mirar por Jesús, ideaba la forma de que sus deudores se hundieran cada 154 vez más, no podía entonces reclamar supuestas obligaciones éticas ni castigos 155 ejemplares. Una vez convertido debe reconocer su estafa usurera, y devolver lo que 156 robó. Contemplemos el final de la historia: Un Zaqueo avenido a la ley, viviendo sin 157 complejos ni disfraces junto a sus hermanos, viviendo sentado junto al Señor, deja fluir 158 confiado y perseverante sus iniciativas, capaz de escuchar y dialogar, y sobre todo de 159 ceder y compartir con alegría de ser.

160 La historia nos dice que muchos pueblos se levantaron de sus ruinas y abandonaron sus 161 ruindades como Zaqueo. Hay que dar lugar al tiempo y a la constancia organizativa y 162 creadora, apelar menos al reclamo estéril, a las ilusiones y promesas, y dedicarnos a la 163 acción firme y perseverante. Por este camino florece la esperanza, esa esperanza que no 164 defrauda porque es regalo de Dios al corazón de nuestro pueblo. Hoy, más que nunca, 165 nos convoca la esperanza. Ella nos inspira y da fuerzas para levantarnos y dejarnos 166 mirar por Dios, abajarnos en la humildad del servicio, y dar dándonos a nosotros 167 mismos. Por momentos soñamos una convocatoria, la esperamos mágica y 168 encantadoramente. El camino es más sencillo: sólo debemos volver al Evangelio, 169 dejarnos mirar como Zaqueo, escuchar el llamado a la tarea común, no disfrazar 170 nuestros límites sino aceptar la alegría de compartir, antes que la inquietud del acaparar. 171 Y entonces sí que escucharemos, dirigida a nuestra Patria, la palabra del Señor: Hoy ha 172 llegado la salvación a esta casa, porque el Hijo del Hombre vino a buscar y a salvar lo 173 que estaba perdido (Lc 19: 10)

174 Homilía del Cardenal Jorge Mario Bergoglio, S.J - Arzobispo De Buenos Aires y 175 Primado de la Argentina 


\section{Homilía Tedeum 25 de mayo de 2003}

"Y entonces, un doctor de la ley se levantó y le preguntó a Jesús para ponerlo a prueba: "Maestro, ¿qué tengo que hacer para heredar la Vida Eterna?" Jesús le preguntó a su vez: "¿Qué está escrito en la ley? ¿Qué lees en ella?" Él le respondió: "Amarás al Señor, tu Dios, con todo tu corazón, con toda tu alma, con todas tus fuerzas y con todo tu espíritu, y a tu prójimo como a ti mismo". " Has respondido exactamente, le dijo Jesús; obra así y alcanzarás la vida". Pero el doctor de la Ley, para justificar su intervención, le hizo esta pregunta: "¿Y quién es mi prójimo?". Jesús volvió a tomar la palabra y le respondió: "Un hombre bajaba de Jerusalén a Jericó y cayó en manos de unos ladrones, que lo despojaron de todo, lo hirieron y se fueron, dejándolo medio muerto. Casualmente bajaba por el mismo camino un sacerdote: lo vio y siguió de largo. También pasó por allí un levita: lo vio y siguió su camino. Pero un samaritano que viajaba por allí, al pasar junto a él, lo vio y se conmovió. Entonces se acercó y vendó sus heridas, cubriéndolas con aceite y vino; después lo puso sobre su propia montura, lo condujo a un albergue y se encargó de cuidarlo. Al día siguiente sacó dos denarios y se los dio al dueño del albergue, diciéndole: "Cuídalo, y lo que gastes de más, te lo pagaré al volver" ¿Cuál de los tres te parece que se portó como prójimo del hombre asaltado por los ladrones?" "El que tuvo compasión de él", le respondió el doctor. Y Jesús le dijo: "Ve, y procede tú de la misma manera".(Lc. 10, 25-37)

El tiempo pascual es un llamado a renacer de lo alto. Al mismo tiempo es un desafío a hacer un profundo replanteo, a resignificar toda nuestra vida -como personas y como Nación- desde el gozo de Cristo resucitado para permitir que brote, en la fragilidad misma de nuestra carne, la esperanza de vivir como una verdadera comunidad. Desde este misterio de alegría íntima y compartida, sentimos resurgir un sol de Mayo al que los argentinos, como siempre, deseamos ver como un recuerdo que es destello de resurrección. Es el esperanzado llamado de Jesucristo a que resurja nuestra vocación de ciudadanos constructores de un nuevo vínculo social. Llamado nuevo, que está escrito, sin embargo, desde siempre como ley fundamental de nuestro ser: que la sociedad se encamine a la prosecución del Bien Común y, a partir de esta finalidad, reconstruya una y otra vez su orden político y social.

La parábola del Buen Samaritano es un ícono iluminador, capaz de poner de manifiesto la opción de fondo que debemos tomar para reconstruir esta Patria que nos duele. Ante tanto dolor, ante tanta herida, la única salida es ser como el Buen Samaritano. Toda otra opción termina o bien del lado de los salteadores o bien del lado de los que pasan de largo, sin compadecerse del dolor del herido del camino. Y "la patria no ha de ser para nosotros -como decía un poeta nuestro- sino un dolor que se lleva en el costado". La parábola del Buen Samaritano nos muestra con qué iniciativas se puede rehacer una comunidad a partir de hombres y mujeres que sienten y obran como verdaderos socios (en el sentido antiguo de conciudadanos). Hombres y mujeres que hacen propia y acompañan la fragilidad de los demás, que no dejan que se erija una sociedad de exclusión, sino que se aproximan -se hacen prójimos- y levantan y rehabilitan al caído, para que el Bien sea Común. Al mismo tiempo la Parábola nos advierte sobre ciertas actitudes que sólo se miran a sí mismas y no se hacen cargo de las exigencias ineludibles de la realidad humana.

Desde el comienzo de la vida de la Iglesia, y especialmente por los Padres capadocios, el buen samaritano fue identificado con el mismo Cristo. Él es el que se hace nuestro prójimo, el que levanta de los márgenes de la vida al ser humano, el que lo pone sobre sus hombros, se hace cargo de su dolor y abandono y lo rehabilita. El relato del buen Samaritano, digámoslo claramente, no desliza una enseñanza de ideales abstractos, ni se circunscribe a la funcionalidad de una moraleja ético-social. Sino que es la Palabra viva 
del Dios que se abaja y se aproxima hasta tocar nuestra fragilidad más cotidiana. Esa Palabra nos revela una característica esencial del hombre, tantas veces olvidada: que hemos sido hechos para la plenitud de ser; por tanto no podemos vivir indiferentes ante el dolor, no podemos dejar que nadie quede "a un costado de la vida", marginado de su dignidad. Esto nos debe in-dignar. Esto debe hacernos bajar de nuestra serenidad para "alterarnos" por el dolor humano, el de nuestro prójimo, el de nuestro vecino, el de nuestro socio en esta comunidad de argentinos. En esa entrega encontraremos nuestra vocación existencial, nos haremos dignos de este suelo, que nunca tuvo vocación de marginar a nadie.

El relato se nos presenta con la linealidad de una narración sencilla, pero tiene toda la dinámica de esa lucha interna que se da en la elaboración de nuestra identidad, en toda existencia "lanzada al camino" de hacer patria. Me explico: puestos en camino nos chocamos, indefectiblemente, con el hombre herido. Hoy y cada vez más ese herido es mayoría. En la humanidad y en nuestra patria. La inclusión o la exclusión del herido al costado del camino define todos los proyectos económicos, políticos, sociales y religiosos. Todos enfrentamos cada día la opción de ser buenos samaritanos o indiferentes viajantes que pasan de largo. Y si extendemos la mirada a la totalidad de nuestra historia y a lo ancho y largo de la Patria, todos somos o hemos sido como estos personajes: todos tenemos algo de herido, algo de salteador, algo de los que pasan de largo y algo del Buen Samaritano. Es notable cómo las diferencias de los personajes del relato quedan totalmente transformadas al confrontarse con la dolorosa manifestación del caído, del humillado. Ya no hay distinción entre habitante de Judea y habitante de Samaria, no hay sacerdote ni comerciante; simplemente están dos tipos de hombre: los que se hacen cargo del dolor y los que pasan de largo, los que se inclinan reconociéndose en el caído, y los que distraen su mirada y aceleran el paso. En efecto, nuestras múltiples máscaras, nuestras etiquetas y disfraces se caen: es la hora de la verdad, ¿nos inclinaremos para tocar nuestras heridas? ¿Nos inclinaremos a cargarnos al hombro unos a otros? Este es el desafío de la hora presente, al que no hemos de tenerle miedo. En los momentos de crisis la opción se vuelve acuciante: podríamos decir que en este momento, todo el que no es salteador o todo el que no pasa de largo, o bien está herido o está poniendo sobre sus hombros a algún herido.

La historia del buen Samaritano se repite: se torna cada vez más visible que nuestra desidia social y política está logrando hacer de esta tierra un camino desolado, en el que las disputas internas y los saqueos de oportunidades nos van dejando a todos marginados, tirados a un costado del camino. En su parábola, el Señor no plantea vías alternativas, ¿qué hubiera sido de aquel malherido o del que lo ayudó, si la ira o la sed de venganza hubieran ganado espacio en sus corazones? Jesucristo confía en lo mejor del espíritu humano y con la Parábola lo alienta a que se adhiera al amor de Dios, reintegre al dolido y construya una sociedad digna de tal nombre.

La Parábola comienza con los salteadores. El punto de partida que elige el Señor es un asalto ya consumado. Pero no hace que nos detengamos a lamentar el hecho, no dirige nuestra mirada hacia los salteadores. Los conocemos. Hemos visto avanzar en nuestra Patria las densas sombras del abandono, de la violencia utilizada para mezquinos intereses de poder y división, también existe la ambición de la función pública buscada como botín. La pregunta ante los salteadores podría ser: ¿Haremos nosotros de nuestra vida nacional un relato que se queda en esta parte de la parábola? ¿Dejaremos tirado al herido para correr cada uno a guarecerse de la violencia o a perseguir a los ladrones? 
¿Será siempre el herido la justificación de nuestras divisiones irreconciliables, de nuestras indiferencias crueles, de nuestros enfrentamientos internos? La poética profecía del Martin Fierro debe prevenirnos: nuestros eternos y estériles odios e individualismos abren las puertas a los que nos devoran de afuera El pueblo de nuestra Nación demuestra, una y otra vez, la clara voluntad de responder a su vocación de ser buenos samaritanos unos con otros: ha confiado nuevamente en nuestro sistema democrático a pesar de sus debilidades y carencias, y vemos cómo se redoblan los esfuerzos solidarios para volver a tejer una sociedad que se fractura. Nuestro pueblo responde con silencio de Cruz a las propuestas disolutorias y soporta hasta el límite la violencia descontrolada de quienes están presos del caos delincuencial.

La Parábola nos hace poner la mirada, redobladamente, en los que pasan de largo. Esta peligrosa indiferencia de pasar de largo, inocente o no, producto del desprecio o de una triste distracción, hace de los personajes del sacerdote y del levita un no menos triste reflejo de esa distancia cercenadora, que muchos se ven tentados a poner frente a la realidad y a la voluntad de ser Nación. Hay muchas maneras de pasar de largo que se complementan: una ensimismarse, desentenderse de los demás, ser indiferente, otra: un solo mirar hacia afuera. Respecto a esta última manera de pasar de largo, en algunos es acendrado el vivir con la mirada puesta hacia fuera de nuestra realidad, anhelando siempre las características de otras sociedades, no para integrarlas a nuestros elementos culturales, sino para reemplazarlos. Como si un proyecto de país impostado intentara forzar su lugar empujando al otro; en ese sentido podemos leer hoy experiencias históricas de rechazo al esfuerzo de ganar espacios y recursos, de crecer con identidad, prefiriendo el ventajismo del contrabando, la especulación meramente financiera y la expoliación de nuestra naturaleza y -peor aún- de nuestro pueblo. Aún intelectualmente, persiste la incapacidad de aceptar características y procesos propios, como lo han hecho tantos pueblos, insistiendo en un menosprecio de la propia identidad. Sería ingenuo no ver algo más que ideologías o refinamientos cosmopolitas detrás de estas tendencias; más bien afloran intereses de poder que se benefician de la permanente conflictividad en el seno de nuestro pueblo.

Inclinación similar se ve en quienes, aparentemente por ideas contrarias, se entregan al juego mezquino de las descalificaciones, los enfrentamientos hasta lo violento, o a la ya conocida esterilidad de muchas intelectualidades para las que "nada es salvable si no es como lo pienso yo". Lo que debe ser un normal ejercicio de debate o autocrítica, que sabe dejar a buen recaudo el ideario y las metas comunes, aquí parece ser manipulado hacia el permanente estado de cuestionamiento y confrontación de los principios más fundamentales. ¿Es incapacidad de ceder en beneficio de un proyecto mínimo común o la irrefrenable compulsión de quienes sólo se alían para satisfacer su ambición de poder?

Tácitamente los "salteadores del camino" han conseguido como aliados a los que "pasan por el camino mirando a otro lado". Se cierra el círculo entre los que usan y engañan a nuestra sociedad para esquilmarla, y los que supuestamente mantienen la pureza en su función crítica, pero viven de este sistema y de nuestros recursos para disfrutarlos afuera o mantienen la posibilidad del caos para ganar su propio terreno. No debemos llamarnos a engaño, la impunidad del delito, del uso de las instituciones de la comunidad para el provecho personal o corporativo y otros males que no logramos desterrar, tienen como contracara la permanente desinformación y descalificación de todo, la constante siembra de sospecha que hace cundir la desconfianza y la perplejidad. El engaño del "todo está mal" es respondido con un "nadie puede arreglarlo". Y, de esta 
144 manera, se nutre el desencanto y la desesperanza. Hundir a un pueblo en el desaliento es 145 el cierre de un círculo perverso perfecto: la dictadura invisible de los verdaderos 146 intereses, esos intereses ocultos que se adueñaron de los recursos y de nuestra capacidad de opinar

pensar.

148 Todos, desde nuestras responsabilidades, debemos ponernos la patria al hombro, porque los tiempos se acortan. La posible disolución la advertimos en otras oportunidades, en esta misma fecha patria. Sin embargo muchos seguían su camino de ambición y superficialidad, sin mirar a los que caían al costado: esto sigue amenazándonos.

152 Miremos finalmente al herido. Los ciudadanos nos sentimos como él, malheridos y 153 tirados al costado del camino. Nos sentimos también desamparados de nuestras 154 instituciones desarmadas y desprovistas, ayunos de la capacidad y la formación que el 155 amor a la patria exigen.

156 Todos los días hemos de comenzar una nueva etapa, un nuevo punto de partida. No 157 tenemos que esperar todo de los que nos gobiernan: esto sería infantil, sino más bien 158 hemos de ser parte activa en la rehabilitación y el auxilio del país herido. Hoy estamos 159 ante la gran oportunidad de manifestar nuestra esencia religiosa, filial y fraterna para 160 sentirnos beneficiados con el don de la Patria, con el don de nuestro pueblo, de ser otros 161 buenos samaritanos que carguen sobre sí el dolor de los fracasos, en vez de acentuar 162 odios y resentimientos. Como el viajero ocasional de nuestra historia, sólo falta el deseo 163 gratuito, puro y simple de querer ser Nación, de ser constantes e incansables en la labor 164 de incluir, de integrar, de levantar al caído. Aunque se automarginen los violentos, los que sólo se ambicionan a sí mismos, los difusores de la confusión y la mentira. Y que otros sigan pensando en lo político para sus juegos de poder, nosotros pongámonos al servicio de lo mejor posible para todos. Comenzar de abajo y de a uno, pugnar por lo más concreto y local, hasta el último rincón de la patria, con el mismo cuidado que el viajero de Samaria tuvo por cada llaga del herido. No confiemos en los repetidos discursos y en los supuestos informes acerca de la realidad. Hagámonos cargo de la realidad que nos corresponde sin miedo al dolor o a la impotencia, porque allí está el Resucitado. Donde había una piedra y un sepulcro, estaba la vida esperando. Donde había una tierra desolada nuestros padres aborígenes y luego los demás que poblaron nuestra Patria, hicieron brotar trabajo y heroísmo, organización y protección social.

175 Las dificultades que aparecen enormes son la oportunidad para crecer, y no la excusa 176 para la tristeza inerte que favorece el sometimiento. Renunciemos a la mezquindad y el 177 resentimiento de los internismos estériles, de los enfrentamientos sin fin. Dejemos de 178 ocultar el dolor de las pérdidas y hagámonos cargo de nuestros crímenes, desidias y 179 mentiras, porque sólo la reconciliación reparadora nos resucitará, y nos hará perder el 180 miedo a nosotros mismos. No se trata de predicar un eticismo reivindicador, sino de 181 encarar las cosas desde una perspectiva ética, que siempre está enraizada en la realidad. 182 El samaritano del camino se fue sin esperar reconocimientos ni gratitudes. La entrega al 183 servicio era la satisfacción frente a su Dios y su vida, y por eso, un deber. El pueblo de 184 esta Nación anhela ver este ejemplo en quienes hacen pública su imagen: hace falta grandeza de alma, porque sólo la grandeza de alma despierta vida y convoca.

186 No tenemos derecho a la indiferencia y al desinterés o a mirar hacia otro lado. No 187 podemos "pasar de largo" como lo hicieron los de la parábola. Tenemos responsabilidad 188 sobre el herido que es la Nación y su pueblo. Se inicia hoy una nueva etapa en nuestra 189 Patria signada muy profundamente por la fragilidad: fragilidad de nuestros hermanos 
190 más pobres y excluidos, fragilidad de nuestras instituciones, fragilidad de nuestros

191 vínculos sociales...

192 ¡Cuidemos la fragilidad de nuestro Pueblo herido! Cada uno con su vino, con su aceite y
193 su cabalgadura.

194 Cuidemos la fragilidad de nuestra Patria. Cada uno pagando de su bolsillo lo que haga 195 falta para que nuestra tierra sea verdadera Posada para todos, sin exclusión de ninguno. 196 Cuidemos la fragilidad de cada hombre, de cada mujer, de cada niño y de cada anciano, 197 con esa actitud solidaria y atenta, actitud de projimidad del Buen Samaritano.

198 Que nuestra Madre, María Santísima de Luján, que se ha quedado con nosotros y nos 199 acompaña por el camino de nuestra historia como signo de consuelo y de esperanza, 200 escuche nuestra plegaria de caminantes, nos conforte y nos anime a seguir el ejemplo de 201 Cristo, el que carga sobre sus hombros nuestra fragilidad.

202 Buenos Aires, 25 de mayo de 2003.

204 Jorge Mario Bergoglio s.j.

205 Arzobispo de Buenos Aires 


\section{Homilía de Tedeum del 25 de mayo de 2004}

Jesús fue a Nazaret, donde se había criado; el sábado entró como de costumbre en la sinagoga y se levantó para hacer la lectura. Le presentaron el libro del profeta Isaías y, abriéndolo, encontró el pasaje donde estaba escrito: "El Espiritu del Señor está sobre mí, porque me ha consagrado por la unción. El me envió a llevar la Buena Noticia a los pobres, a anunciar la liberación a los cautivos y la vista a los ciegos, a dar la libertad a los oprimidos y proclamar un año de gracia del Señor".Jesús cerró el Libro, lo devolvió al ayudante y se sentó. Todos en la sinagoga tenían los ojos fijos en él. Entonces comenzó a decirles: "Hoy se ha cumplido este pasaje de la Escritura que acaban de oír". Todos daban testimonio a favor de él y estaban llenos de admiración por las palabras de gracia que salían de su boca. Y decían: "¿No es éste el hijo de José?". Pero él les respondió: "Sin duda ustedes me citarán el refrán: 'Médico, cúrate a ti mismo'. Realiza también aquí, en tu patria, todo lo que hemos oído que sucedió en Cafarnaún". Después agregó: "Les aseguro que ningún profeta es bien recibido en su tierra. Yo les aseguro que había muchas viudas en Israel en el tiempo de Elías, cuando durante tres años y seis meses no hubo lluvia del cielo y el hambre azotó a todo el país. Sin embargo, a ninguna de ellas fue enviado Elías, sino a una viuda de Sarepta, en el país de Sidón. También había muchos leprosos en Israel, en el tiempo del profeta Eliseo, pero ninguno de ellos fue curado, sino Naamán, el sirio". Al oír estas palabras, todos los que estaban en la sinagoga se enfurecieron y, levantándose, lo empujaron fuera de la ciudad, hasta un lugar escarpado de la colina sobre la que se levantaba la ciudad, con intención de despeñarlo. Pero Jesús, pasando en medio de ellos, continuó su camino. Jesús bajó a Cafarnaún, ciudad de Galilea, y enseñaba los sábados. Y todos estaban asombrados de su enseñanza, porque hablaba con autoridad. (Lc. 4: 16-32)

1. En estos días finales del tiempo pascual, en vísperas de la venida del Espíritu Santo, nos reunimos para retornar a las fuentes del Mayo de los argentinos. Volvemos al núcleo histórico de nuestros comienzos, no para ejercitar nostalgias formales sino buscando la huella de la esperanza. Hacemos memoria del camino andado para abrir espacios al futuro. Como nos enseña nuestra fe: de la memoria de la plenitud se hace posible vislumbrar los nuevos caminos. Del paso fundante de Dios y de su contundente gracia salvadora en nuestra historia es posible recomenzar, inspirarse, fortalecerse, proyectarse. La víspera de Pentecostés, tiempo del Espíritu, reúne a los vapuleados creyentes de hoy, no menos que a los sacudidos y frágiles apóstoles de entonces, para recomenzar. La fragilidad de la barca no debe causar temores ni prevenciones, la inmensidad del mar de la vida y de la historia es suavizada por el viento, ese soplo de Dios que desde el primer día nos impulsa y conduce. Alguna verdadera, misteriosa e inclaudicable confianza nos llevó a los argentinos a congregarnos, tantas veces a lo largo de nuestra historia, en este solar de mayo, como en aquel año de 1810, buscando el viento que nos conduzca por buen camino.

2. También aquellos fieles que oían a Jesús en su Nazaret natal estaban esperanzados. Había respeto y admiración por la autoridad que emanaba de su persona y sus palabras parecían mover aires renovados en el alma del pueblo. La propuesta de aquel joven Rabbi era algo largamente esperado: una "Buena Noticia para los pobres", una manera nueva de "ver" la vida y la tan ansiada libertad. Esa buena nueva de Jesús es inclusiva. A los mismos que libera y sana les encomienda liberar y sanar a otros. Hablando con su pueblo, Jesús mismo siente la confirmación de que las palabras proféticas se cumplen en el mismo momento en que las pronuncia. Iluminado y ungido, habla movido por el Espíritu. El relato evangélico nos lo muestra a las claras: allí estaba el Espíritu, un tiempo nuevo de Dios, un viento que es seguro. Y la gente sentía lo mismo: hubo aplausos y gestos de admiración.

Sin embargo, el final del relato nos deja perplejos. Alguien deslizó sibilinamente "Pero, ¿no es éste el hijo de José" el carpintero? y entonces cambió el humor de los presentes: 
lo sacaron a empujones y lo llevaron a un barranco con la intención de despeñarlo o de apedrearlo. Pero "Jesús pasó por entre medio de ellos y siguió su camino", se fue a Cafarnaún, pueblo de Galilea, a predicar de nuevo al aire libre, entre la gente sencilla del pueblo fiel. Lo que al principio parecía el acontecimiento de una gran barca lanzada a los mares de la conquista de la libertad, se convierte en un ir a buscar la humilde barca de Simón, el pescador del lago de Genesaret: el Señor se escabulle y se pierde como uno más entre la multitud. Ni siquiera se comporta como un rebelde dispuesto a poner el pecho a las pedradas.

3. Jesús, fiel al estilo profético que acompañaba su paso entre los hombres, realiza gestos simbólicos, ¿qué significa este dejar Nazaret su "patria"? Me parece ver aquí una fuerte protesta contra los que se sienten tan incluidos que excluyen a los demás. Tan clarividentes se creen que se han vuelto ciegos, tan autosuficientes son en la administración de la ley que se han vuelto inicuos.

Por eso Jesús se aparta y elige el pequeño sendero, irse por entremedio de su pueblo, "la oscura senda" (de la que hablara Fray Luis De León), que es precisamente el camino de los pobres; el de los pobres de cualquier pobreza que signifique despojo al alma y, a la vez, confianza y entrega a los demás y a Dios. En efecto, el que sufre el despojo de sus bienes, de su salud, de pérdidas irreparables, de las seguridades del ego y -en esa pobreza- se deja conducir por la experiencia de lo sabio, de lo luminoso, del amor gratuito, solidario y desinteresado de los otros, conoce algo o mucho de la Buena Nueva.

Los argentinos hemos sufrido todas estas pobrezas, algunos las viven y testimonian desde años y décadas. Pues bien, hoy como en aquel tiempo, Jesús sigue escabullido entre los más pequeños y pobres de nuestro pueblo.

Pero, ¿por qué deja a aquellos exaltados solos con sus piedras y sus deseos de desbarrancar todo lo que no concuerde con sus ideas? ¿Qué les impide a estos transitar esta senda de la escucha de la Buena Nueva? Tal vez el tácito enfrentamiento, en sus vidas, entre sabiduría e ilustración. Lo sabio es añejamiento de vida donde campea la prudencia, la capacidad de comprensión, el sentido de pertenencia. Lo ilustrado, en cambio, puede correr el riesgo de dejarse empapar de ideologías -no de ideas- de prejuicios, de facciosidad. La impaciencia de las elites ilustradas no entiende el laborioso y cotidiano caminar de un pueblo, ni comprende el mensaje del sabio. $\mathrm{Y}$ en aquel entonces había también elites ilustradas que aislaban su conciencia de la marcha de su pueblo, que negociaban su pertenencia y su fe, también existían las izquierdas ateas y las derechas descreídas abroqueladas en sus seguridades marginales ajenas a todo sentir popular. Algo de aquella cerrazón emocional, de esas expectativas no colmadas las sintió Jesús como verdaderas cegueras del alma. Tal actitud parece evocar los reclamos histriónicos, inmediatistas; esas reacciones y posturas extremas o superficiales en las que solemos caer.

4. No pocas veces, el mundo mira asombrado un país como el nuestro, lleno de posibilidades, que se pierde en posturas y crisis emergentes y no profundiza en sus hendiduras sociales, culturales y espirituales, que no trata de comprender las causas, que se desentiende del futuro. Frente a esta realidad debemos quizá pedir luz acerca de la segunda promesa profética: ha venido a dar vista a los ciegos, y plantearnos el hecho de nuestra ceguera. 
Admitámoslo. Necesitamos que el Señor nos ilumine porque tantas veces parecemos cegados y vivimos de encandilamientos efímeros que nublan y opacan. Es como capricho del que no quiere saber nada con el resplandor que brota del silencioso pensar y hacer balance de nuestros aciertos y yerros. No buscamos la luz mansa que brota de la verdad, no apostamos a la espera laboriosa, que cuida el aceite y mantiene la lámpara encendida.

El fruto vano de la ceguera es la falsa ilusión. Todos ilusionamos una fuerza profética y mesiánica que nos libere, pero cuando el trayecto de la verdadera libertad comienza por la aceptación de nuestras pequeñeces y de nuestras dolorosas verdades, nos tapamos los ojos y llenamos nuestras manos con piedras intolerantes. Somos prontos para la intolerancia. Nos hallamos estancados en nuestros discursos y contradiscursos, dispuestos a acusar a los otros, antes que a revisar lo propio. El miedo ciego es reivindicador y lleva a menudo a despreciar lo distinto, a no ver lo complementario; a ridiculizar y censurar al que piensa diferente, lo cual es una nueva forma de presionar y lograr poder. No reconocer las virtudes y grandezas de los otros, por ejemplo, reduciéndolos a lo vulgar, es una estrategia común de la mediocridad cultural de nuestros tiempos. ¡Que no sobresalgan! ¿Que no nos desafien....a ver si todavía tenemos que salir de nuestro adormecimiento, de nuestra cómoda paz de los cementerios! ¡Pensar que es el hijo de José!, decían..., anticipo en palabras de lo que sucedería en los hechos; y Jesús ya recibía el primer piedrazo de nuestra vulgaridad.

La difamación y el chisme, la trasgresión con mucha propaganda, el negar los límites, bastardear o eliminar las instituciones, son parte de una larga lista de estratagemas con las que la mediocridad se encubre y protege, dispuesta a desbarrancar ciegamente todo lo que la amenace. Es la época del "pensamiento débil". Y si una palabra sabia asoma, es decir si alguien que encarna el desafío de la sublimidad aun a costa de no poder cumplir muchos de nuestros anhelos, entonces nuestra mediocridad no se para hasta despeñarlo. Despeñados mueren próceres, prohombres, artistas, científicos, o simplemente cualquiera que piense más allá del inconsciente discurso dominante. No los descubrimos sino tarde. Despreciamos al "hijo del carpintero"... Pero no hay empacho en poner en el candelero la luz fatua de cualquier perversión, refregada día y noche por la imagen y la abundante información; un embeleso de voiyeurismo donde todo está permitido, donde el goce marketinero de lo morboso parece atrapar los sentidos y los sumerge en la nada. Prohibido pensar y crear. Prohibido el arrojo, el heroísmo y la santidad. Para estos ciegos tampoco son bien vistos lo sugerente y lo sutil, la armonía propia de lo bello, porque implican el trabajo modesto y humilde del talento.

5. La vitalidad y creatividad de un pueblo, y de todo ser humano, sólo se da y se puede contemplar luego de un largo camino acompañado de limitaciones, de intentos y fracasos, de crisis y reconstrucción... Y el pecado mayor de todos los cultores de la ceguera es el vacío de identidad que producen, esa terrible insatisfacción que nos proyectan y no permiten que nos sintamos a gusto en nuestra propia patria. Se despoja lo identitativo profundo y se propone una identidad "artificial", "de cartón", maquillada, de utilería. Es la contraposición entre lo identitativo de un pueblo y esa otra identidad importada, construída a uso y conveniencia de sectores privados. Jesús, dejando a los ciegos, elige el sendero humilde que lo lleva al pueblo fiel, el que se admira con sencillez ante esa doctrina que devuelve la vista a los ciegos que desean ver. 
140 6. ¿Qué vemos cuando se nos permite abrir los ojos? Vemos a Dios escabullido en 141 medio de su pueblo, caminando con su pueblo.

142 Vemos a un Jesús con los pies en la tierra, cultivando corazones como buen Sembrador

143 (y cultivar es la raíz de cultura), elaborando la verdadera comida del espíritu, ésa que 144 cimienta la comunión entre los habitantes de la Nación. Se trata de esa comida 145 espiritual, ese pan que, partido, permite ver; el que se saborea acompañando a los que 146 sufren cotidianamente, sin pretender sacar provecho o rédito; el que abraza a todos aun 147 a los que no lo reconocen.

148 El que, con su misericordia, se hace cargo de miserias y maldades, sin adulaciones ni 149 justificativos demagógicos, sin conceder a modas y costumbres.

150 Es sabiduría: el pan que nos abre los ojos y nos previene de la ceguera de la 151 mediocridad, proponiéndonos una vida que tiende hacia lo mejor y no la ética del 152 minimalismo o el eticismo exquisito de laboratorio, a la vez es la Sabiduría que 153 comprende profundamente y perdona todo.

154 Es el pan que nos hace sentir el respaldo que da la sapiencial constancia de recorrer y de 155 tocar el dolor humano concreto, sin mediaciones ideológicas ni interpretaciones 156 evasivas o hechas para la opinión pública.

157 Y porque se da como Pan, es la Sabiduría que con su testimonio y su palabra sabe que el 158 alma de un pueblo crece cuando hay trabajo del espíritu en lo más profundo, sensible y 159 creativo. Ése es su incansable desafío educativo, lejos de la pura información 160 enciclopedista o tecnocrática, más lejos aún de la subordinación a esquemas de poder. 161 Porque su verdadero poder es el del amor infinito y confiado de Dios, que no se ata a 162 razas ni a formas culturales ni a sistemas, sino que les da su sentido y significado 163 último: ayudar a ser y disfrutar de la alegría de ser, que exige renuncia y se resiste a 164 quedar encerrado en los propios horizontes mezquinos.

165 7. La ceguera del alma nos impide ser libres. En el episodio evangélico de hoy, muchos 166 de los que anhelaban la libertad, al levantar sus piedras intolerantes, demostraban la 167 misma crueldad que el imperio invasor. Querían librarse del enemigo de afuera sin 168 aceptar al enemigo interior. Y sabemos que copiar el odio y la violencia del tirano y del 169 asesino es la mejor manera de ser su heredero. Por eso, cuando Jesús propone, siguiendo 170 a Isaías, la liberación de la cautividad y la opresión, podemos preguntarnos: ¿De qué 171 cautividad y de cuál opresión? Y responder: primero la de nosotros mismos: la de 172 nuestra desorientación e inmadurez, para poder reclamar la libertad de opresiones 173 externas. Si las cadenas fueran de hierro, si la presencia de ejércitos externos fuera 174 evidente, lo sería también la necesidad de libertad. Pero cuando la cautividad proviene 175 de nuestras sangrantes heridas y luchas internas, de la ambición compulsiva, de las 176 componendas de poder que absorben las instituciones, entonces ya estamos cautivos de 177 nosotros mismos. Una cautividad que se expresa -entre otras cosas- en la dinámica de la 178 exclusión. No sólo la exclusión que se hace a través de las estructuras injustas, sino 179 también las que potenciamos nosotros, esa otra forma de exclusión por medio de 180 actitudes: indiferencia, intolerancia, individualismo exacerbado, sectarismo. Excluimos 181 de la identidad y quedamos cautivos de la máscara; excluímos de la identidad y 182 resquebrajamos la pertenencia...porque "identificarse" supone "pertenecer". Sólo desde 183 la pertenencia a un pueblo podemos entender el hondo mensaje de su historia, los rasgos 
184 de su identidad. Toda otra maniobra de afuera es nada más que un eslabón de la cadena, 185 en todo caso hay un cambio de amos, pero el status es el mismo.

186 8. La propuesta es liberarnos de nuestra mediocridad, esa mediocridad que es el mejor 187 narcótico para esclavizar a los pueblos. No hacen falta ejércitos opresores. 188 Parafraseando a nuestro poema nacional podemos decir que un pueblo dividido y 189 desorientado ya está dominado.

190 Una confusa cultura mediática mediocrizada nos mantiene en la perplejidad del caos y 191 de la anomia, de la permanente confrontación interna y de "internas", distraídos por la 192 noticia espectacular para no ver nuestra incapacidad frente a los problemas cotidianos.

193 Es el mundo de los falsos modelos y de los libretos. La opresión más sutil es entonces la 194 opresión de la mentira y del ocultamiento,...eso sí; a base de mucha información, 195 información opaca y, por tal, equívoca.

196 Curiosamente tenemos más información que nunca y, sin embargo, no sabemos qué 197 pasa. Cercenada, deformada, reinterpretada, la sobreabundante información global 198 empacha el alma con datos e imágenes, pero no hay profundidad en el saber. Confunde 199 el realismo con el morbo manipulador, invasivo, para el que nadie está preparado pero 200 que, en la paralizante perplejidad, obtiene réditos de propaganda. Deja imágenes 201 descarnadas, sin esperanza.

202 9. Pero gracias a Dios, nuestro pueblo también conoce el camino humilde del machacar 203 diario, el mismo de tantos años de vida oculta. El de apostar al bien y sostener sin estar 204 seguros del resultado. Conoce el silencio dolorido y pacífico pero -a la vez- rebelde, de 205 muchos años de desencuentros, promesas falsas, violencias e injusticias expoliadoras. 206 Sin embargo, encara diariamente sus tareas, con mucho desgaste social y un tendal de 207 marginaciones. Año a año renueva su confiada espera marchando peregrino a tantos 208 lugares donde Dios y su Madre lo esperan para el diálogo reconfortante, fortalecedor.

209 Este pueblo no cree en las estratagemas mentirosas y mediocres. Tiene esperanzas pero 210 no se deja ilusionar con soluciones mágicas nacidas en oscuras componendas y 211 presiones del poder. No lo confunden los discursos; se va cansando de la narcosis del 212 vértigo, el consumismo, el exhibicionismo y los anuncios estridentes. Para su 213 conciencia colectiva- ésa que brota del alma profunda de nuestro pueblo- estas cosas 214 son sólo "piedrazos". Nuestro pueblo sabe, tiene alma, y porque podemos hablar del 215 alma de un pueblo, podemos hablar de una hermenéutica, de una manera de ver la 216 realidad, de una conciencia. Advierto en nuestro pueblo argentino una fuerte conciencia 217 de su dignidad. Es una conciencia histórica que se ha ido moldeando en hitos 218 significativos. Nuestro pueblo sabe que la única salida es el camino silencioso, pero 219 constante y firme. El de proyectos claros, previsibles, que exijan continuidad y 220 compromiso de todos los actores de la sociedad y con todos los argentinos. Nuestro 221 pueblo quiere vivir y realizar la convocatoria del Cristo que camina entre nosotros, 222 animando nuestros corazones, uno a uno, reavivando las reservas de nuestra memoria cultural. Nuestro pueblo sabe y quiere porque ama la Creación del Padre y lo comunitario, como lo hicieron y lo hacen nuestros aborígenes; porque se arroja y compromete con sus ideales, como nos lo legaron los españoles que poblaron nuestro suelo; porque es humilde, piadoso y festivo como nuestros criollos; porque es laborioso e incansable como nuestros mayores inmigrantes. 
228 10. Vimos al Señor proclamando su mensaje en medio de su pueblo. Observamos cómo

229 las elites ilustradas no toleran el paciente camino cotidiano de los humildes y sencillos

230 y, llevados de su histeria exquisita, procuran desbarrancar y apedrear. Señalamos los

231 valores de un pueblo con Dios metido en su humilde sendero. Recorrimos nuestro

232 camino histórico como pueblo y observamos nuestras contradicciones. Notamos la

233 necesidad de ser curados de nuestra ceguera y librados de la cautividad y la

234 opresión. La apelación sapiencial que hoy podemos hacer, inspirándonos en el

235 Evangelio es a todas luces muy clara: toda transformación profunda que se encamine

236 hacia la serenidad de espíritu, hacia la convivencia y hacia una mayor dignidad y

237 armonía en nuestra Patria, solamente puede lograrse desde nuestras raíces; apelando a la

238 conciencia que busca y se duele, que goza y se compromete con los otros, que acepta el

239 orden pacificador de la ley justa y la memoria de los logros colectivos que van

240 formando nuestro ser común. Apelando a la conciencia que no se pierde en la ceguera

241 de las contradicciones secundarias, sino que se concentra en los grandes desafíos, y que

242 además compromete sus recursos prioritarios para hacer de esto su proyecto educativo,

243 para todas las generaciones y sin límites.

244 La Palabra, como la historia, nos deja un código donde espejarnos. Pero, además, hay

245 también espejismos. Hoy como siempre los argentinos debemos optar. No hacerlo es ya

246 una opción, pero trágica. O elegimos el espejismo de la adhesión a la mediocridad que

247 nos enceguece y esclaviza o nos miramos en el espejo de nuestra historia, asumiendo

248 también todas sus oscuridades y antivalores, y adherimos de corazón a la grandeza de

249 aquellos que lo dejaron todo por la Patria, sin ver los resultados, de aquellos que

250 transitaron y transitan el camino humilde de nuestro pueblo, siguiendo las huellas de ese

251 Jesús que pasa en medio de los soberbios, los deja desconcertados en sus propias

252 contradicciones y busca el camino que exalta a los humildes, camino que lleva a la cruz,

253 en la que está crucificado nuestro pueblo, pero que es camino de esperanza cierta de

254 resurrección; esperanza de la que todavía ningún poder o ideología lo ha podido

255 despojar. 


\title{
1 Homilía de Tedeum 25 de mayo de $2005^{\mathrm{i}}$
}

\author{
Mi alma canta la grandeza del Señor... \\ (porque) elevó a los humildes... acordándose de su misericordia”" \\ (Lc. 1,48.52.54) \\ ¿Queridos hermanos y hermanas!
}

1. Estamos celebrando con acción de gracias el amanecer de nuestra Nación en esta gesta del pueblo de Buenos Aires, cuando reconoce que esta región del imperio español tiene el derecho a gobernarse a sí misma.

Como todo comienzo, fue modesto pero impredecible, ya que fue el inicio de un pueblo que sería la Nación Argentina. "Una Nación es fundamentalmente la comunidad de hombres convocados por diversos aspectos, pero, sobre todo, por el vínculo de la misma cultura" (1). Realidad "de orden principalmente espiritual: que impulsa a los hombres, iluminados por la verdad, a comunicarse entre sí los más diversos conocimientos; a defender sus derechos y cumplir sus deberes; a desear los bienes del espíritu; a disfrutar en común del justo placer de la belleza en todas sus manifestaciones; a sentirse inclinados continuamente a compartir con los demás lo mejor de sí mismos; a asimilar con afán, en provecho propio, los bienes espirituales del prójimo" (2).

2. Recuerdo cargado de gratuidad hacia los que lo gestaron, los conocidos y los desconocidos, necesario y vinculante acto de justicia hacia el pasado, que nos reencuentra con la identidad más original.

Escribía Eduardo Mallea: "Haberse originado es originarse constantemente, nacer es seguir naciendo, y si no sabemos cómo y para qué llevamos en nosotros tan constantes nacimientos, esta ignorancia adquirirá, bajo el aspecto de una vida que se perpetua, el valor de una muerte que se repite" (3).

O sea, recordar es necesario para seguir caminando, seguir naciendo en la vocación original de ser nación, en el esfuerzo cotidiano de cada ciudadano, en el insustituible compromiso de poner lo mejor de cada uno al servicio del bien común, con el sacrificio de todos, especialmente de quienes más saben, más tienen y más pueden. Como creyentes, agradeciendo a Dios la sabiduría y la fortaleza para esta aventura ciudadana.

3. También es digno de destacar que la Nación, por sus autoridades nacionales encabezadas por el Sr. Presidente de la República, eligiera el interior de la República para esta recordación llena de gratitud.

En la Madre de Ciudades, en Santiago del Estero, primer testimonio del encuentro de culturas del siglo XVI, en esta parte del continente sudamericano, hace 452 años.

Era el comienzo de la plasmación de la utopía de un "nuevo mundo", de la vocación del hombre de hacerse prójimo y vivir fraternalmente.

Fundar una ciudad es un proyecto de comunión y deseo de "convivir los hermanos unidos", como reza el salmo. Es rescatar del espacio natural un espacio reservado al hombre, espacio político (polis), en el cual se da sus leyes para la convivencia pacífica y constructiva, para que cada hombre y mujer, para que sus familias, tengan la oportunidad, el tiempo propicio para crecer no solo materialmente sino también espiritualmente. No es un proyecto mezquino el convivir, aunque intereses mezquinos y rivalidades lo puedan enredar, como toda obra humana. 
Porque la historia de la convivencia humana, lo sabemos, es historia de tensiones. Por ello, en aquellas tensiones originales, en esta región del Continente, en Santiago se levantaron las primeras voces en defensa de los derechos humanos no siempre respetados en los pueblos originales. Pastores y misioneros los reclamaron con su predicación comprometida contra la prepotencia que denegaba igualdad, justicia y trato fraterno.

Enseñanza que debemos recoger cada día a la hora de querer ser nación: solamente en el respeto del Derecho, expresado en leyes justas, puede construirse la convivencia social, que la defiendan de la arbitrariedad y del privilegio, con el olvido de los más pobres, débiles y sufrientes.

4. También nos digna esta presencia de la Nación en este día, en esta etapa de la historia de Santiago. Hoy gozamos del funcionamiento de las instituciones democráticas elegidas por el pueblo soberano y juez. Esto es un fruto madurado por el mismo pueblo santiagueño que se puso de pie para reclamar justicia, cansado de años de arbitrariedad. Este pueblo reclamó dignidad y entró en dialogo, que ayuda a superar la cultura de la confrontación, de la sospecha, de la dialéctica del amigo-enemigo; dialogo en el que no solo expresó inquietudes sino que también imaginó soluciones, como la necesaria reforma de la Constitución Provincial. Dialogo diversificado, creativo y creciente, que es muestra de una ciudadanía también creciente, que quiere hacerse cargo de la historia, para que nunca más nadie se enseñoree de nuestro pueblo.

Santiago no necesita tutores ni tiene dueños que le señalen arbitrariamente el derrotero de la historia, y menos que lo quieran imponer autoritariamente.

5. En este día tan especial para la Nación, ofrezcamos todos, sin excepción, nuestro compromiso sincero y concreto por seguir gestando una Nación libre y soberana, donde ninguno de sus hijos sea excluido; respetuosa del derecho y con la cordura del diálogo en la resolución de sus conflictos. Para ello los creyentes ponemos nuestra mirada en el Señor para decir: Jesucristo, Señor de la historia, te necesitamos.

Nos sentimos heridos y agobiados.

Precisamos tu alivio y fortaleza.

Queremos ser nación, una nación cuya identidad sea la pasión por la verdad y el compromiso por el bien común. Danos la valentía de la libertad de los hijos de Dios para amar a todos sin excluir a nadie, privilegiando a los pobres y perdonando a los que nos ofenden, aborreciendo el odio y construyendo la paz.

Concédenos la sabiduría del diálogo y la alegría de la esperanza que no defrauda. Tú nos convocas. Aquí estamos, Señor, cercanos a María, que desde Luján nos dice: ¡Argentina! ¡Canta y camina! Jesucristo, Señor de la historia, te necesitamos. Amén 


\section{Notas:}

99 (1) CEA, Iglesia y Comunidad Nacional, n. 77

100 (2) Juan XXIII, Pacem in terris, n.36

101 (3) Historia de una pasión argentina, Bs. As., Sudamericana, 1961, p. 21

102

103 Mons. Juan Carlos Maccarone, obispo de Santiago del Estero

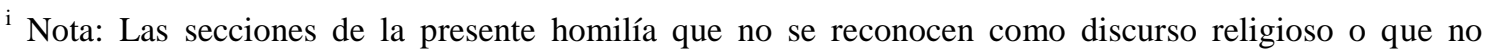
corresponden a ninguna etiqueta reconocida como parte del género homilía quedan expresadas en texto

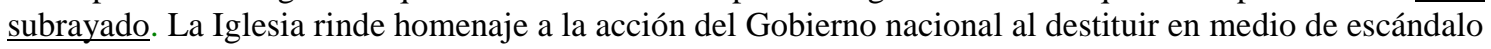
y acusaciones de corrupción y violación de los derechos humanos, a la Gobernadora, Nina Aragonés de Juárez, quien había asumido el poder después de que su esposo, Carlos Juárez, gobernara la provincia de Santiago del Estero por medio siglo.
} 


\section{Homilía para el Te Deum del 25 de mayo de 2006}

La fecha que hoy conmemoramos y por lo que estamos celebrando la Acción de Gracias al Señor llamada Te Deum (A ti Dios, primeras palabras del himno de Acción de gracias) es el puntapié inicial con el que la dirigencia criolla tomó las riendas del poder, poniendo así los cimientos de la organización democrática que con sus más y menos forjaron nuestra patria. Los personajes que intervinieron en esta primera semana de mayo de nuestra historia no tenían todo claro, ni la certeza de lo que vendría con el tiempo. Comienzan rompiendo los lazos jurídicos con la corona española, con la casa reinante, lo que conlleva un quebrantamiento de las leyes de la administración interna. "Todo, señala un autor, era una situación de hecho", por eso la Junta que asumió el gobierno invitó a los cabildos del interior a enviar sus representantes. De una y otra forma el pueblo participó y fue decidiendo su destino libre.

La historia de la patria como la historia de cualquier familia tiene sus momentos buenos y malos, por todos ellos hoy en nuestra Basílica Catedral nos reunimos para dar Gracias y para rezar por todos los que hacemos la patria.

Terminamos de escuchar en la primera lectura de San Pablo a Timoteo, 2, 1-4: "Ante todo recomiendo que se hagan plegarias, oraciones, súplicas y acciones de gracias por todos los hombres; por los gobernantes y por todos los constituidos en autoridad, para que podamos vivir una vida tranquila y apacible con toda piedad y dignidad. Esto es bueno y agradable a Dios, nuestro Salvador, que quiere que todos los hombres se salven y lleguen al conocimiento pleno de la verdad."

Santo Tomás de Aquino comentando este texto nos hace ver en otras estas seis cosas:

1) San Pablo nos enseña el valor de la oración en común: "Ante todo recomiendo que se hagan plegarias..." uno de los requisitos principales de la vida cristiana es la oración, que sirve para defenderse de los peligros, de las tentaciones y para crecer en el bien. "Mucho vale la oración perseverante del justo" (Santiago 5, 16).

2) Nos enseña que no debemos querer doblegar la voluntad de Dios, ya que el está siempre dispuesto a lo bueno: "Dios quiere que todos los hombres se salven y lleguen al conocimiento de la verdad." Lo que la oración ha de hacer, dice Santo Tomás, es procurar que nuestro corazón esté elevado a Dios, en unión con él. En la oración debemos encontrar lo que nos conviene.

3) Si bien no debemos querer doblegar la voluntad de Dios, debemos orar con fe, con seguridad, nos dice el apóstol Santiago en su carta. "Pidan con fe, sin sombra de duda." $(1,6)$. Nuestra oración debe ser confiada en todos los momentos de la historia y de nuestra vida, esto nos lleva a la esperanza, todavía estamos en tiempo Pascual, tiempo de la gran Esperanza: Jesucristo, nuestro salvador Resucitado.

4) Debemos rezar "por todos los hombres" Santo Tomás dice que la "oración es la intérprete de nuestro deseo" porque cuando rezamos pedimos lo que deseamos. Ahora bien, la caridad pide que deseemos el bien a todos cuantos ella 
encierra (es decir todos los hombres y mujeres) "El Padre nos amó y envió a su Hijo en rescate por todos", nos dice el Evangelio de Juan.

5) Debemos rezar por todos, pero especialmente por quienes tienen autoridad, como comencé diciendo el 25 de mayo de 1810 el Pueblo confió su autoridad a la junta para que está y las formas de gobierno que llegan a nuestros días nos gobiernen. Los que gobiernan en nombre del Pueblo deben especialmente recibir luz y guía de la oración (La Biblia nos enseña siempre esto: "Rogad por la vida de Nabucodonosor, rey de Babilionia, y por la vida de Baltasar, su hijo." Baruc 1, 2. San Pablo a los Romanos, dice: "Toda persona está sujeta a las potestades" Y san Pedro en su primera carta 2, 13: "Sean sumisos a toda humana criatura, y esto por respeto a Dios: ya sea el gobernante, o los que rigen las naciones, como puestos por Él.") el fin de la oración por los gobernantes la da San Pablo en las palabras: "para que podamos vivir una vida tranquila y apacible con toda piedad y dignidad." La oración y el buen ejemplo cristiano deben guiar la vida de la sociedad, la vida de cuantos cobija nuestra patria, nacidos aquí o no.

6) "Esto es bueno y agradable a Dios" Cuando una cosa es buena en sí, debemos hacerla, esa cosa buena es la oración, por todos, por la Patria en su día, por los que gobiernan. Orar dice Santo Tomás de Aquino es una obra de caridad, porque es agradable a los ojos de Dios, nada es bueno ante Dios si no es ofrecido en caridad.

El 25 de mayo de 1810 nuestro Pueblo decidió comenzar a ser un Pueblo independiente. Cada pueblo tiene el derecho a su propia tierra con su soberanía y su libertad. Esto lo han dicho siempre los papas a todos y para todos. No se pueden defender los propios y legítimos derechos pisoteando los de los demás. Por eso ante las discusiones y / o pretensiones por una misma tierra, los papas se han pronunciado a favor de que cada Estado goce de la misma libertad, soberanía y seguridad. Y esto se hace tendiendo puentes y no muros.

Hoy es el día de la Patria demos gracias a Dios por ella y aprendamos la lección de esta palabra de Dios que meditamos: aprender, en la caridad, a rezar siempre a Dios por todos, uniéndonos a Dios por medio de la oración confiada para obtener la paz y la quietud en los corazones de cada uno, argentinos por nacimiento o adopción, para que esa paz y quietud sea reflejada en nuestra sociedad. Esto hará una sociedad cada día mejor. Muchos de los problemas de hoy pueden tener su origen en el pasado, pero lo más importante es entender a dónde nos llevará la situación actual. Por eso a la gente le gustan las profecías y vaticinios, aunque la mayoría de las veces se trate de puras opiniones. La única profecía cierta es que Cristo es el sentido de toda la historia. En él debemos crecer como Patria.

Las Actas del Cabildo de Luján, nos recuerda Mons. Presas prueban que allí "el Grito de Mayo obtuvo el primer eco y fue celebrado con júbilo y fiestas ante la imagen de la Virgen Santísima." Una vez más pongámonos bajo el manto de nuestra Madre la Virgen y utilizando parte de una oración por los gobernantes de San Clemente Romano, mártir en el año 97 de nuestra era, le Pedimos a Dios: "Danos concordia y paz a nosotros y a todos los habitantes de la tierra, como la diste a nuestros padres cuando te invocaban santamente en la fe y en la verdad (1Tim 2, 7). Haznos estar bajo tu nombre omnipotente y lleno de fuerza... Señor lleva a buen fin los deseos según lo que es bueno 
87 y agradable en tu presencia... Tú sólo eres capaz de cumplir estos bienes y otros más 88 grandes, por eso nosotros te agradecemos por medio del gran Sacerdote y protector de 89 nuestras almas, Jesucristo por el cual ahora te damos gloria y alabanza, de generación en 90 generación y por los siglos de los siglos. Amén"

91 + Mons. Rubén H. Di Monte. Arzobispo de Mercedes-Luján

92 Juan Antonio Presas. Ir a Luján es un deber. Editorial Dunken. Buenos Aires 2004.

93 Págs. 33ss.

94 Ad Corinto. 60, 4-61. 


\section{Homilía de Tedeum del 25 de mayo de 2007}

2

3

4 Sr. Presidente de la Nación y Sra. de Kirchner

5 Sr. Gobernador de la Provincia de Mendoza y Sra. de Cobos

6 Sr. Vicepresidente de la Nación

7 Sres. Presidentes de ambas cámaras legislativas de la Nación

8 Sres. Gobernadores

9 Sr. Nuncio Apostólico y Decano del Cuerpo Diplomático, S.E.R. Mons. Adriano

10 Bernardini

11 Sres. Embajadores

12 Autoridades Nacionales, Provinciales y Municipales

13 Pueblo todo de la Patria

14

15

16

17

18

19

\section{Queridos hermanos y hermanas:}

Con cordial alegría la Provincia de Mendoza, sus autoridades y su pueblo, recibimos a las máximas autoridades nacionales para conmemorar, en la bonita tierra del sol y del buen vino, los acontecimientos del 25 de mayo de 1810 que dieron origen a nuestra historia como Nación independiente.

Comenzamos los festejos en esta histórica Basílica, que cobija a Nuestra Señora del Carmen de Cuyo, ante cuya Imagen el general José de San Martín confió al amparo de la Madre de Dios el Ejército Libertador, antes de iniciar el cruce de los Andes.(1) Rezamos para ello el solemne Te Deum, por este nuevo aniversario de la Patria.

A la Virgen Santísima imploro su asistencia para cumplir el alto honor de predicar la homilía y para interpretar cabalmente el sentir de los presentes y de los argentinos todos en esta ocasión privilegiada: ¡Ave María!

Este antiguo himno hunde sus raíces en una añeja tradición de la Iglesia y ha servido en los momentos significativos de la historia argentina para unir la entera comunidad en actitudes ennoblecedoras y dignificantes.

Más de 1600 años tiene este cántico. Mucho tiempo se creyó que fue compuesto por San Ambrosio de Milán para el bautismo de San Agustín. Estudios más precisos, del siglo XIX, lo atribuyen al obispo San Nicetas de Remesiana, en Serbia, hacia fines del siglo IV o principios del V, aunque algunos autores lo remontan hasta el año 252 y lo atribuyen a San Cipriano de Cartago(2). Utilizado en las solemnidades litúrgicas y en innumerables acontecimientos civiles fue compañero singular de la vida de la Iglesia y de los pueblos cristianos a lo largo de los siglos.

En nuestra historia, fueron memorables -entre muchos- antes de los sucesos de Mayo de 1810, los entonados la tarde del 14 de agosto de 1806, dando gracias al Señor por la Reconquista de Buenos Aires, y el proclamado el 19 de Julio de 1807 luego de la exitosa Defensa contra el invasor extranjero(3).

La Junta de Mayo, que asumió la soberanía del pueblo ante la invasión napoleónica, ordenó el Te Deum, con la mayor solemnidad posible, como uno de sus primeros actos de gobierno, lo cual se concretó en la Catedral de Buenos Aires, en ceremonia presidida por el Obispo Lué y Riega, y fue predicado por el sacerdote Doctor Diego Estanislao Zavaleta, el 30 de mayo de 1810(4). Pocos días después, el cabildo de Luján dispuso hacer rezar, el 17 de junio, un Te Deum por la instalación "del primer gobierno patrio".(5) 
Famosos fueron otros Te Deum conmemorativos del nacimiento de la Patria: el del

50 Pbro. Dr. Victorio de Achega, en 1813, en la Catedral de Buenos Aires; el del Deán

51 Funes, en la Catedral de Córdoba, el 25 de mayo de 1814; el de Fray Pantaleón García,

52 en la misma Catedral al año siguiente; el del Pbro. Dr. Ignacio de Castro Barros, en

53 Tucumán, el 25 de mayo de 1815. En mayo de 1816, en vísperas de la apertura de las

54 sesiones del Congreso de Tucumán “el Pbro. Manuel Acevedo pronunció el Te Deum”.

55 (6)

56 Y para detenernos en algunos de los más significativos luego de la declaración de

57 la Independencia, recordemos tan sólo tres: el que precede a las deliberaciones

58 constituyentes convocadas por Urquiza, en Santa Fe, en 1852(7); el que pronunció el

59 célebre orador de Constitución, Fray Mamerto Esquiú para estimular su jura, el 9 de

60 julio de 1853 en Catamarca(8); y el que conmemoró el primer centenario de la Patria, el

6125 de mayo de 1910 en la Iglesia Catedral de Buenos Aires.(9)

62 De este modo, este "cántico de alabanza y de acción de gracias que se eleva a

63 Aquel que, siendo eterno, nos acompaña en el tiempo sin abandonarnos nunca y que

64 siempre vela por la humanidad con la fidelidad de su amor misericordioso"(10), ha

65 marcado los hitos fundamentales de nuestra historia como Nación y ha expresado el

66 sentir común de los argentinos en momentos clave de nuestra vida política.

67 Enraizados en esta fecunda tradición, tan rica en su policromía de lugares y de

68 eventos significativos apenas esbozada, en Mendoza, hoy, en un año inmerso en la

69 dinámica de los tiempos electorales, nos presentamos ante Dios para rezar una vez más

70 como argentinos el solemne Te Deum. Compartimos así un momento profundamente

71 religioso ante Dios, de todos los argentinos, en nombre de todos los argentinos y para

72 beneficio de todos los argentinos.

75 valor?

76 Expresa la actitud más noble y bella que el hombre puede tener ante Dios, que la

77 criatura puede manifestar a su Creador, como se esclarece en su título más antiguo y sus

78 primeras palabras: ¡Te Deum laudamus! ¡A Ti, oh Dios, te alabamos!

79 Los hombres nos ponemos ante Dios en diversas ocasiones: a veces para pedirle o

80 suplicarle, por ejemplo, cuando la enfermedad, el sufrimiento o la muerte nos

81 amenazan; otras, para agradecerle, cuando hemos constatado su ayuda; o para pedirle

82 perdón, cuando tenemos la valentía de reconocer nuestros errores o miserias; también,

83 para ponerlo por testigo de nuestras buenas intenciones y propósitos, como el día en que

84 un ciudadano asume una responsabilidad pública. Son siempre momentos significativos

85 de nuestra existencia personal y social.

86 Pero la alabanza supera en mucho estos momentos. Porque pone en ejercicio la 87 actitud más plena y realizadora que puede vivenciar el hombre.

88 Una vez, un niño - que podía llamarse Eduardo María, o Néstor, o Cristina, o Julio, 89 ... o como cualquiera de nosotros-, en el catecismo, al recibir la respuesta a la pregunta 90 fundamental ¿para que hemos sido creados?, cuando su catequista le decía: "para 91 conocer, amar y servir a Dios en esta vida, y para alabarlo eternamente en el Cielo", 92 pensaba para sí: "¿Qué aburrido va a ser esto de alabar a Dios eternamente, sin hacer 93 otra cosa, por tiempos infinitos!"

94 Sólo cuando fue más grande, y tuvo la experiencia más consciente del amor, pudo 95 madurar aquella respuesta y percibir su sencilla profundidad y su riqueza.

96 En efecto, la experiencia del amor nos sirve para entender la alabanza. 
Sabemos bien que la felicidad plena no se obtiene por el dinero, el poder, la fama,

98 el placer o cualquiera de sus sustitutos. La felicidad auténtica se da en el amor, cuando

99 somos amados y cuando podemos amar, cuando nos realizamos en el amor y somos

100 felices por el amor.

101 Cuando un enamorado goza con la presencia de su amada, o la enamorada con la de

102 su amado, cuando ya no necesitan agradecerse mutuamente sus regalos o los dones que

103 intercambian, o sus cariños, sino que, en un salto cualitativo más excelso, brota del

104 corazón el piropo genuino, el elogio o la palabra apropiada -... y los que aman

105 encuentran las mejores expresiones -, y cuando el amado y la amada pueden decirse

106 mutuamente: "me alegro que tu seas", cuando la alegría profunda del corazón se hace

107 elogio simplemente por la existencia, la belleza o la bondad personal del otro tal como

108 es ... allí, entonces, empieza a gustarse lo que es la alabanza.

109 Cuando el hombre descubre al "Dios que es amor"(11) y puede alcanzar en su 110 relación con Él la correspondencia en el amor, la alabanza brota cristalina y pura, como 111 manantial o vertiente de alta montaña, en la sencillez del corazón limpio y humilde.

112 Como en Jesús, tal como nos lo ha presentado el hermoso Evangelio que escuchamos 113 hace instantes(12).

114 En este sentido, el Catecismo de la Iglesia Católica nos dice que "la oración de 115 alabanza, totalmente desinteresada, se dirige a Dios; canta para Él y le da gloria no sólo 116 por lo que ha hecho sino porque Él es"(13).

117 Por eso también San Agustín, en inmortales palabras, expresó al comienzo de sus 118 Confesiones: “ ... A pesar de todo, el hombre, pequeña parte de tu creación, quiere 119 alabarte. Tú mismo le incitas a ello, haciendo que encuentre sus delicias en tu alabanza, 120 porque nos has hecho ¡oh Señor! para Ti y nuestro corazón está inquieto mientras no 121 descansa en Ti”'(14).

Una característica singular del Te Deum es que, como la oración que nos enseñó Jesús, el Padre Nuestro, nos lleva a orar a Dios en plural, no en singular.

Expresa de este modo la pertenencia de cada uno a la familia de Dios, en la cual nuestra condición de hijos nos hermana a todos los hombres. Nos previene contra todo individualismo egoísta, encandilante y destructivo, y nos abre a una solidaridad corresponsable y enaltecedora.

Y al unirnos a la multitud de los apóstoles, profetas y mártires, nos invita a tomar conciencia de nuestra pertenencia a una historia común, en la cual cada uno, según su lugar, contribuye al bien de los demás y, desde su presente, se ancla en la memoria del pasado para construir el futuro. A los argentinos nos viene muy bien esta perspectiva abarcadora e integradora, para mirar los casi dos siglos de historia común que nos orientan esperanzados a celebrar el próximo bicentenario.

Además el Te Deum asocia a todos: laicos y religiosos, autoridades y pueblo, grandes y pequeños, ricos y pobres. Como una sinfonía que suma todas las notas de la escala. Como un coro que integra los diversos registros para lograr la más bella expresión. Esta unión armónica refleja, entre otras cosas, la legítima autonomía y la adecuada cooperación que la autoridad civil y la religiosa se deben mutuamente, para servir adecuada e integralmente a todo el hombre, a cada hombre y a todos los hombres.

Más aún, al asociarnos incluso a los mismos ángeles para aclamar a Dios con el

143 lleva a alturas maravillosas, como la música que exalta nuestro espíritu y da vida y 144 movimiento al ritmo del amor y la alabanza. 
146 Ahora bien, cuando el caminante eleva su mirada al cielo, o el montañista a la 147 cumbre lejana, sus ojos no sólo se deleitan con las bellezas del horizonte, sino que sus 148 pupilas se calibran más ajustadamente y pueden, por ello, conducir mejor sus pasos 149 sobre el sendero que pisan metro a metro para alcanzar la meta. De modo similar, 150 cuando el hombre se eleva en la alabanza a su Creador, su mirada se purifica y su 151 conciencia se ennoblece, para mejor guiar las opciones de su libertad en la construcción 152 de la historia cotidiana y llegar un día a la alabanza eterna del Cielo.

153 La conciencia es ese sagrario inviolable de cada persona donde el eco de la voz de 154 Dios se hace oír a cuantos quieren con rectitud usar una brújula fiel, que todo hombre 155 posee como clave de su dignidad y de su libertad, para ser felices y navegar sin perder el 156 rumbo en las tormentas y los avatares de la vida personal o social. Por eso, para quienes 157 creen en Dios, la fe ilumina su conciencia, y para quienes no tienen este don, su 158 conciencia recta les puede permitir, incluso, alcanzar a Dios.

159 El Te Deum bien vivido lleva a un rico intercambio entre Dios y la conciencia.

160 Puede, incluso, anticipar y preparar ese diálogo que la conciencia de cada uno tendrá 161 con Él al final de la propia existencia, cuando, luego de la muerte, sea ella nuestro 162 testigo ante su juicio justo y misericordioso.

163 De algún modo, el movimiento profundo que inspira el Te Deum hace eco de las 164 tablas de la ley que Moisés recibió en el Sinaí y que también se halla en la conciencia de 165 todo hombre.(15)

166 En efecto, en la primera de ellas estaban inscriptos los primeros tres mandamientos: 167 amar a Dios sobre todas las cosas, no tomar su santo nombre en vano, santificar las 168 fiestas. En la segunda de ellas, los demás: no matar, no fornicar, no robar, no mentir, 169 etc. Como gozne o bisagra, el mandamiento cuarto: "honrarás a tu padre y a tu madre". 170 ¡Justamente, el que funda el amor a la patria, la tierra o herencia de los padres!(16).

171 ¿No nos estará indicando este orden que para servir bien a la patria, como lo 172 hicieron nuestros próceres de Mayo, es necesario guardar las dos tablas del decálogo?

173 ¿No nos está diciendo que la fidelidad a Dios nos ayudará como hermanos, a erradicar 174 plenamente el crimen, la deshonestidad, la falsía y otros males, en la tierra que hemos 175 heredado? ¿No nos está mostrando que respetar la segunda tabla nos permitirá mirar a 176 Dios con serena confianza al terminar cada día y al llegar al atardecer de la vida, ante su 177 veredicto final?

178 No tengo duda de que ponernos con rectitud de conciencia ante Dios nos ayudará a 179 construir la Patria. No tengo duda de que construir la Patria con responsabilidad nos 180 prepara del mejor modo a cada uno para el encuentro definitivo con Dios. En ambas 181 direcciones nos ayudará, a todos los argentinos, rezar bien el Te Deum.

189 agradecer también muchas gracias particulares. La limitación del tiempo me ciñe, en 190 esta ocasión, a centrarme sólo en una.

191 Para octubre de este año está convocada la sexta elección presidencial consecutiva 192 desde 1983. A lo largo de nuestra historia, los desencuentros entre los argentinos 
impidieron, muchas veces -en vocablos de Cornelio Saavedra- que fuera el pueblo el que confiriera la autoridad y mando(17), y frenaron -en palabras del Santo Padre Benedicto XVI-nuestra fidelidad a la democracia.(18)

Cuarenta y tres años trascurrieron desde Mayo de 1810 hasta que logramos darnos, en Mayo de 1853, una Constitución que alcanzó vigencia y aceptación. La sustancial mejora del régimen electoral establecida en 1912, que nos alejaba del fraude, sólo permitió la realización de tres elecciones presidenciales consecutivas; y de 1930 a 1983, sólo dos presidentes concluyeron el mandato para el que fueron elegidos.(19)

Estimo, pues, oportuno dar gracias a Dios por estar a las puertas de nuevas elecciones en el ejercicio de nuestra democracia, y que, con los logros y las dificultades que hemos experimentado en estos años, consolidemos la vida sana de la República como un anhelo común.

Y no viene mal recordar a este respecto que recientemente, nuestro actual Sumo Pontífice, instaba a "la fidelidad a la democracia, ya que es la única que puede garantizar la igualdad y los derechos de todos. En efecto, se da una especie de dependencia recíproca entre democracia y justicia, que impulsa a todos a comprometerse de modo responsable para que se salvaguarde el derecho de cada uno, especialmente de los débiles o marginados. La justicia es el banco de prueba de una auténtica democracia. Dicho esto, no hay que olvidar que la búsqueda de la verdad constituye al mismo tiempo la condición de posibilidad de una democracia real y no aparente: "Una democracia sin valores se convierte con facilidad en un totalitarismo visible o encubierto, como demuestra la historia" (Centesimus annus, 46). De aquí la invitación a trabajar para que aumente el consenso en torno a un marco de referencias comunes. De lo contrario, el llamamiento a la democracia corre el riesgo de ser una mera formalidad de procedimiento, que perpetúa las diferencias y acentúa los problemas"..(20)

Por último, para terminar, señalemos también que, en el Te Deum, la alabanza lleva a la súplica.

Es lo normal, en la comunión de amor y de confianza que crea la alabanza. Por eso también es bueno que como argentinos, en este día, supliquemos a Dios por nuestra Patria.

Recientemente los obispos argentinos, reunidos en Asamblea Plenaria, han manifestado algunos desafíos prioritarios para afrontar en este año electoral(21). Propongo que los hagamos este día objeto de petición, como lo presentaremos en la oración de los fieles a continuación.

Queridos hermanos y hermanas: Solo me resta invitarlos a hacer nuestro el Te Deum que el coro, en la versión americana de Doménico Zipoli(22), entonará seguidamente.

Unamos en oración nuestros corazones a la belleza de su canto, para que, al ponernos ante Dios, la alabanza nos haga crecer a todos en el amor, ilumine nuestras conciencias y nos disponga a servir mejor a la patria en este nuevo aniversario.

$$
\text { ¡Viva la Patria! }
$$

Amén.

\section{Homilía de monseñor Eduardo María Taussig, obispo de San Rafael, en el Te Deum del 25 de Mayo de 2007(Basílica San Francisco de Asís - Mendoza)}


243 (1) Fue el 5 de enero de 1817, cuando el General San Martín le entregó su bastón de mando, nombrándola Generala del Ejército. Cfr. José Pacífico Otero, Historia del Libertador Don José de San Martín, Sopena, Buenos Aires, 1949, $2^{\mathrm{a}}$ ed., tomo I, pág. 577ss.

(2) Cfr. The Catholic Encyclopedia, voz "Te Deum", en On line Edition Copyright (c) 1999 by Kevin Knight. (Traducido por Beatriz N. Prestamo). También en The Oxford Dictionary of the Christian Church, Edited by F. L. CROSS and E. A. LIVINGSTONE, Oxford University Press, 1988, 2a ed., voz "Niceta", en pág. 969; y voz "Te Deum", en pág. 1343.

(3) Rezar el Te Deum de la Reconquista fue la primera disposición del Cabildo Abierto del 14 de agosto de 1806. Cfr. Vicente Sierra, Historia de la Argentina, Unión de Editores Latinos, Buenos Aires, 1960, tomo IV, pág. 156. Sobre el Te Deum de la Defensa, que predicó el Pbro. Dr. Joaquín Ruiz, cfr. Vicente Sierra, o. C., tomo IV, pág. 223. También cfr. Cayetano Bruno, Historia de la Iglesia en la Argentina, Don Bosco, Buenos Aires, 1971, vol. VII (1800-1812), pág. 115.

(4) Cfr. Cayetano Bruno, Historia de la Iglesia en Argentina, Buenos Aires, Don Bosco, 1971, vol. VII (18001812), págs. 276-278.

257 (5) Cfr. Vicente Sierra, Historia de la Argentina, Garriga Argentina S.A., Buenos Aires, 1962 , tomo V, pág. 61.

(6) Cfr. J. C. Zuretti, Nueva historia eclesiástica argentina, Buenos Aires, Itinerarium, 1972, pág. 187.

(7) "El 20 de noviembre de 1852, Urquiza decretó la instalación solemne del Congreso General Constituyente de las Provincias de la Confederación Argentina en la ciudad de Santa Fe, previo un solemne Te Deum en la Iglesia matriz de dicha ciudad" (Reg. Of. de la República Argentina, tomo III, pág. 49, no 3038). Cfr. Antonio Sagarna, "La organización nacional. La Constitución de 1853", en: Academia Nacional de la Historia, Historia de la Nación Argentina, "La confederación y Buenos Aires, hasta la organización definitiva de la Nación en 1862", ANH, Buenos Aires, 1946, vol. VIII, pág. 211.

(8) Cfr. el texto del discurso Laetamur de gloria vestra, en Fray Mamerto Esquiú - La vida y la obra - Cinco sermones célebres, Buenos Aires, 1958, págs. 17-26. El Eco de Córdoba, año XXI, 31-III-1883, publicó la historia de este sermón de 1853, relatada por el mismo Esquiú. Cfr. también Horacio M. Sánchez de Loria Parodi, Las ideas político jurídicas de Fray Mamerto Esquiú, Educa, Buenos Aires, 2002 , pág. 50. Es interesante que en la reciente Convención Nacional Constituyente de 1994, cuando resolvió sesionar bajo la advocación de Fray Mamerto Esquiú al aprobar los proyectos presentados por los convencionales catamarqueños, se recuerda que el Sermón de la Constitución fue pronunciado luego del Te Deum: cfr. Convención Nacional Constituyente, 16a Reunión - 3a Sesión Ordinaria (Continuación), 25 de julio de 1994, pág. 1950 y ss.

(9) Al que asistió no sólo el presidente de la Nación, sino también el de nuestra nación hermana de Chile y la Infanta Isabel de España en representación de nuestra madre Patria, además de una gran cantidad de delegaciones civiles y eclesiásticas extranjeras, y al que se sumaron los celebrados en otras capitales de provincia y en innumerables templos del país. Cfr. Efeméride del 25 de mayo de 1910, Revista Eclesiástica del Arzobispado de Buenos Aires, Año X, 1910, págs. 654-655. Cfr. también: Programa de las fiestas religiosas con que la Iglesia argentina puede asociarse a la celebración del Centenario de Mayo (Buenos Aires, febrero 17, 1910, M. Ezcurra, R. P. Carranza, D. Figueroa), Revista Eclesiástica del Arzobispado de Buenos Aires, Año X, 1910, págs. 274-275; Circular al clero (abril 1910) REABA, Año X, 1910, págs. 464465; "Nota de la Comisión del Centenario pro festejos religiosos al Prelado, 11 de julio 1910", REABA Año X, 1910, pág. 728). Cfr. Nota del Arzobispo de Buenos Aires, Mons. Mariano Antonio Espinosa al Intendente Municipal de la Capital Federal, Dr. J. Manuel Güiraldes (15 de julio de 1910) en respuesta a la suya del 9 de junio (Cfr. Revista Eclesiástica del Arzobispado de Buenos Aires, año X, 1910, pág. 603), con la reseña de los principales actos y ceremonias religiosas que en los diversos templos de esta capital se han celebrado para conmemorar el primer centenario de nuestra independencia. "En este breve cuadro podrá verse el entusiasmo con que el Clero se ha asociado a los festejos con que el Gobierno y pueblo han conmemorado la gran efeméride nacional" (cfr. "La Iglesia en el Centenario", REABA, Año X, 1910, pág. 729ss).

(10) Cfr. S.S. Benedicto XVI, Te Deum, 31-XII-2005. En los puntos suspensivos se omite lo siguiente: "porque es un deber nuestro, además de una necesidad del corazón, alabar y dar gracias".

(11) Como lo ha presentado de modo tan sublime S.S. Benedicto XVI en su Encíclica programática Deus Caritas est, del 25 de diciembre de 2005.

(12) El Evangelio proclamado en la celebración fue San Mateo 11,25-27: "En esa oportunidad Jesús dijo: iTe alabo, Padre, Señor del Cielo y de la tierra, por haber ocultado estas cosas a los sabios y a los prudentes y haberlas revelado a los pequeños. Si, Padre, porque así lo has querido ..."

(13) Cfr. Catecismo de la Iglesia Católica, núm. 2649.

300 (15) Dice San Pablo: "Cuando los paganos, que no tienen la Ley, guiados por la naturaleza, cumplen las prescripciones de la Ley, aunque no tengan la Ley, ellos son ley para sí mismos, y demuestran que lo que ordena la Ley está inscrito en sus corazones. Así lo prueba el testimonio de su propia conciencia, que unas veces los acusa y otras los disculpa, hasta el Día en que Dios juzgará las intenciones ocultas de los hombres por medio de Cristo Jesús, conforme a la Buena Noticia que yo predico". Cfr. Rom. 2, 14-16. 
(16) Cfr. Catecismo de la Iglesia Católica, ns. 2197-2199.

(17) La frase "...no quede duda de que el pueblo es el que confiere la autoridad o mando", fue pronunciada por Cornelio Saavedra en su voto del Cabildo Abierto del 22 de mayo de 1810: cfr. Senado de la Nación, Biblioteca de Mayo. Colección de Obras y Documentos para la Historia Argentina. Antecedentes Documentos Políticos y Legislativos, Tomo XVIII, pág. 16.080, Buenos Aires, 1966; tomado de Archivo General de la Nación, Acuerdos del extinguido Cabildo de Buenos Aires, serie IV, libros LXV, LXVI y LXVII, años 1810 y 1811, págs. 114-148. Es muestra clara de la inspiración en el pensamiento de Francisco Suárez, S.J., por parte de Saavedra y los demás hombres de Mayo: cfr. Guillermo Furlong, S.J., Francisco Suárez fue el filósofo de la Revolución Argentina de 1810, en Atilio Dell'Oro Maini y otros, Presencia y Sugestión del Filósofo Francisco Suárez - Su Influencia en la Revolución de Mayo, págs. 75 a 112, Editorial Guillermo Kraft Limitada, Buenos Aires, 1959. Cfr. también C. A. Floria - C. G. García Belsunce, Historia de los Argentinos, Buenos Aires, Larousse, 1992, pág. 302.

En nuestro tiempo, Juan Pablo II expresó en su encíclica programática, en 1978: "El sentido esencial del Estado como comunidad política, consiste en el hecho de que la sociedad y quien la compone, el pueblo, es soberano de su propia suerte. En este sentido no llega a realizarse si, en vez del ejercicio del poder mediante la participación moral de la sociedad o del pueblo, asistimos a la imposición del poder por parte de un determinado grupo a todos los demás miembros de la sociedad". Cfr. Redemptor Hominis, núm. 17 (recomendamos leer todo el número para apreciar la trascendencia de esta afirmación en nuestro tiempo).

(18) Expresión de Benedicto XVI, citada enseguida: cfr. nota 18.

(19) En efecto, entre 1930 y 1983, sólo los presidentes Agustín P. Justo y Juan Domingo Perón concluyeron su mandato constitucional (1932-1938 y 1946-1952). No así los gobiernos que los sucedieron: Roberto Ortiz Ramón Castillo (1938-1943) y el segundo de Juan D. Perón. Tampoco los gobiernos de Arturo Frondizi (1958-1962), Arturo Illia (1963-1966), ni, finalmente, los gobiernos justicialistas elegidos en 1973: Héctor Cámpora - Juan D. Perón - María Estela Martínez de Perón (1973-1976).

(20) Cfr. Benedicto XVI, Discurso a las Asociaciones Cristianas de Trabajadores Italianos (ACLI), 27 de enero de 2006.

(21) Cfr. Exhortación pastoral de la Conferencia Episcopal Argentina, dada en Pilar el 28 de abril de 2007, al término de la 93.a Asamblea Las súplicas que siguen son tomadas literalmente de esta exhortación pastoral: - "Preservemos la vida ... don de Dios y el primero de los derechos humanos ... desde el momento de la concepción y cuidemos su existencia y dignidad hasta su fin natural; - la familia, fundada en el matrimonio entre varón y mujer, se fortalezca como célula básica de la sociedad y sea la primera responsable de la educación de los hijos; - el bien común prime por sobre los bienes particulares y sectoriales, fortalezca los tres poderes del Estado, cuya autonomía se hace imprescindible para el ejercicio de la democracia, y se afiance por la sanción de leyes justas y por su acatamiento; - la inclusión de todos los ciudadanos permita a todos la participación en los bienes espirituales, culturales y $\quad$ materiales; - el verdadero federalismo contribuya al fortalecimiento institucional de las Provincias, con su necesaria y justa autonomía respecto del poder central - la sociedad crezca en su capacidad de diálogo y en su habilidad para gestar consensos que se traduzcan en políticas de Estado, que orienten hacia un proyecto común de Nación. - la fragmentación y enfrentamientos, que se manifiestan tanto en la impunidad como en desencuentros y resentimientos, den paso a las condiciones para establecer una paz verdadera con la restauración de la justicia, la reconciliación y el perdón ".

(22) Doménico Zípoli, músico toscano fallecido en 1726 en la Estancia Jesuítica de Santa Catalina, en Córdoba, provincia en la que pasó los últimos nueve años de su vida, como novicio de la Compañía de Jesús y componiendo música para su utilización en las misiones. La calidad de las obras que ejecutaban y componían los indígenas de las reducciones es testimonio elocuente de la dignificación que importó para esos pueblos su cristianización. El Te Deum forma parte del repositorio del Archivo Musical de Chiquitos, donde se encuentra registrado con el número 174. Recordemos que Chiquitos, en el actual oriente boliviano, formó parte del Virreinato del Río de la Plata y envió representantes al Congreso de Tucumán. Cfr. La Nuova Enciclopedia della Musica, Garzanti, Milan, 1986, pág. 794; cfr. también Catálogo del archivo musical de Chiquitos, hecho por Leonardo Waisman y Bernardo Illari, 1989.

\section{ORACIÓN POR LA PATRIA}

Jesucristo, Señor de la historia, te necesitamos.

Nos sentimos heridos y agobiados.

Precisamos tu alivio y fortaleza.

Queremos ser nación,

una nación cuya identidad

sea la pasión por la verdad

y el compromiso por el bien común.

Danos la valentía de la libertad de los hijos de Dios

para amar a todos sin excluir a nadie, privilegiando a los pobres

y perdonando a los que nos ofende, 
374

375

376

377

378

379

380

381

382

383 aborreciendo el odio y construyendo la paz.

Concédenos la sabiduría del diálogo

y la alegría de la esperanza que no defrauda.

Tú nos convocas. Aquí estamos, Señor,

cercanos a María, que desde Luján nos dice:

iArgentina! iCanta y camina!

Jesucristo, Señor de la historia, te necesitamos.

Amén .

Conferencia Episcopal Argentina 


\section{Homilía Tedeum 25 de mayo de 2008}

2

3

4

5

6

7

8

Como una respuesta brotada desde lo profundo del corazón a la Palabra de Dios que nos fue proclamada, el pueblo argentino, en este día en el que celebra el $198^{\circ}$ aniversario de la Revolución de Mayo, se "acuerda del largo camino que el Señor Dios nos ha hecho recorrer en la historia".

Se trata de un recuerdo cargado de gratitud y de responsabilidad. De gratitud por la rica herencia que nos legaron los mayores a lo largo de estas casi veinte décadas; de responsabilidad porque el presente nos exige actuar de tal manera que, aprendiendo de los aciertos y errores del pasado enmendemos estos y profundicemos aquellos para poder pergeñar un futuro que ofrezca horizontes a las generaciones que nos han de suceder.

La Providencia ha querido que Salta fuera la sede de la celebración nacional presidida por la Excelentísima Señora Presidenta de la Nación, por el gabinete que la acompaña en su gobierno, por representantes de los poderes legislativo y judicial y por el cuerpo diplomático acreditado en nuestra patria.

En el horizonte de nuestras vidas de argentinos ya despunta la celebración de las fiestas del Bicentenario; acercándonos a ellas, nos sentimos felices porque, desde esta Provincia podemos decir, con humilde convicción, algunos pensamientos que surgen de cara a un nuevo siglo de vida argentina.*

Esta casa guarda la imagen bendita del Señor del Milagro, imagen que viene animando la oración por la patria rezada por tantos argentinos desde hace ya casi siete años. Aquí se nos ofrece un clima familiar en el que quisiera testimoniar una herencia y dirigir un pedido a todos mis hermanos argentinos.

\section{I}

La herencia la recojo de la historia de nuestra provincia. Salta quedó marcada por su amor a la patria desde los inicios de ésta. Baste recordar lo decisivo de aquella batalla conducida por el General Manuel Belgrano el 20 de febrero de 1813 en la consolidación de nuestra independencia. Este pueblo ha madurado en cada generación su conciencia de civilidad alimentado por muchos testimonios de servicio, de desinterés, de proyección. Creo no equivocarme si destaco, espigando en su historia, tres datos que están grabados en el alma de esta provincia y que son: el mensaje del Milagro, el legado de Güemes y el servicio de Facundo de Zuviría.

El Mensaje del Milagro: La historia de Salta se acuna en él. Desde la fundación de esta ciudad en 1.582, primero fue promesa, luego encuentro, después olvido, luego una historia de comunión profunda que culmina en 1.844 cuando el Pueblo hace un pacto con el Señor. Desde entonces el pueblo lo renueva cada año en una primavera pascual.

La profunda experiencia del encuentro con Cristo es para cada salteño y para el pueblo, una experiencia de dignidad que se afirma y de libertad que se recrea. Como el Pueblo de Israel reconoce en el Pacto del Sinaí el nacimiento de su condición de pueblo libre, así el pueblo de Salta, al reconocer que sólo Dios es su Señor, se sabe un pueblo libre y por ello un pueblo digno. Es que la dimensión religiosa de la persona es la base de su dignidad y la custodia de su libertad. Nunca Argentina tuvo miedo a Dios, fuente 
82

de toda razón y justicia y, en esta hora es muy bueno que nos presentemos ante El para alabarlo. "Señor, Dios eterno, alegres te cantamos, a ti nuestra alabanza, a ti, Padre del cielo, te aclama la creación. Postrados ante ti los ángeles te adoran y cantan sin cesar: Santo, santo, santo, Dios del universo; llenos están los cielos y la tierra de tu gloria".

El legado de Güemes. La figura del General Martín Miguel de Güemes es para los salteños un llamado a la entrega por la patria en la fortaleza hasta el heroísmo. Es digno de destacar cómo su acción de defensa de la patria fue acordada con San Martín y Belgrano en un plan estratégico al que fue fiel hasta la muerte porque la patria se lo pedía. Este profundo amor a la tierra que nos vio nacer constituye un aporte al modo de ser del hombre del interior. Hay un estilo generoso, cordial, respetuoso, digno, acogedor, fiel a la palabra dada, que se resume en la palabra gaucho y que cualifica al hombre y a la mujer del interior argentino. Estos valores, que están en la base de la cultura nacional profunda llaman a que los tengamos en cuenta a la hora de pensar nuestra identidad.

El servicio de Facundo de Zuviría. A este ilustre salteño le correspondió presidir el Congreso Constituyente de 1.853 que consagró nuestra Constitución Nacional dando origen al estado organizado que consolidó el crecimiento y la evolución de la Nación. Su figura invita a recrear nuestra fidelidad a la ley y a las instituciones de la patria. Es bueno recordarlo en este año del vigésimo quinto aniversario del regreso a la democracia en la Argentina, convencidos que, como nos enseña la Iglesia, " una auténtica democracia no es sólo el resultado de un respeto formal de las reglas, sino que es el fruto de la aceptación convencida de los valores que inspiran los procedimientos democráticos: la dignidad de toda persona humana, el respeto de los derechos del hombre, la asunción del bien común como fin y criterio regulador de la vida política. Si no existe un consenso general sobre estos valores, se pierde el significado de la democracia y se compromete su estabilidad" (1)

\section{II}

Esta herencia que es viva en el corazón del pueblo, me impulsa a pedirles a todos los argentinos tres compromisos, que los obispos miembros de la Conferencia Episcopal propusimos a todo el pueblo de la patria en el andar de estos años nuestros:

1. Trabajemos por continuar construyendo la Nación que queremos. "Sabemos que una Nación es una comunidad de personas que comparten muchos bienes, pero, sobre todo, una historia, una cultura y un destino común. Por ello debemos volver a la raíz del amor que teje la convivencia social, entendida como un llamado de Dios" (2). Elijamos nuevamente ser argentinos, desarrollemos los valores indispensables de la vida social. "Sólo buenos ciudadanos, que obren con inteligencia, amor y responsabilidad, pueden edificar una sociedad y un estado más justos y solidarios" (3) . Renovemos el esfuerzo por cancelar cada día la deuda social que grava sobre nosotros y nos impele a hacernos cargo sobre todo de los más pobres. Desde esta Salta quisiera invitar a que todos incorporemos verdaderamente en nuestro corazón de argentinos a los aborígenes como hermanos. 
2. Renovemos nuestro esfuerzo por consolidar el sistema democrático desde el respeto a la constitución y a las instituciones de la patria. Cuando el respeto a la ley constituye un bien adquirido cada ciudadano puede sentirse libre y proyectarse dignamente. Lo contrario pone a la nación en un camino involutivo hacia la ley de la selva. ¿Será capaz nuestra generación de avanzar desde la "viveza criolla" hacia la nobleza que compromete? Es preciso continuar trabajando para elevar la calidad de la educación basándola en los inclaudicables valores puestos por Dios en el corazón del hombre. Animémonos a crecer en la honestidad, en la austeridad, en la responsabilidad por el bien común, en la solidaridad y en el espíritu de sacrificio, en la cultura de la familia, de la vida y del trabajo.

3. Apostemos con audacia creativa y confianza renovada a la amistad social y al diálogo como camino para construir la comunidad nacional. El espíritu amplio e incluyente que caracteriza a nuestra patria se plasmó entre otras expresiones en la voluntad de promulgar nuestra constitución para "nosotros, para nuestra posteridad y para todos los hombres del mundo que quieran habitar el suelo argentino". Ese espíritu fraterno hoy nos compromete a recrear los vínculos entre todos los habitantes de esta tierra y nos ilumina para mirar al otro como hermano. Nunca unos contra otros. El diálogo es un instrumento eficaz para convertir la crisis en oportunidad. La fatiga que acompaña su ejercicio no es infecunda ni irrelevante; sabernos encontrar, escuchar y hablar hasta ponernos en el lugar del otro es garantía para avanzar socialmente. Reafirmemos nuestra convicción de que "una sociedad no crece necesariamente cuando lo hace su economía, sino sobre todo cuando madura en su capacidad de diálogo y en su habilidad para gestar consensos que se traduzcan en políticas de estado que orienten hacia un proyecto común de Nación" (4). Avancemos en la construcción de una Patria de hermanos. No neguemos a nuestros niños y a nuestros jóvenes esta señal de esperanza.

Hemos escuchado a Jesús en el Evangelio ofrecerse como Pan vivo bajado del cielo. Hoy la Iglesia católica celebra agradecida en su liturgia este don del Señor hecho pan que perpetúa en la Eucaristía su voluntad de entregarse por nosotros y desde dentro de nosotros darse como el pan, fruto de la tierra y del trabajo del hombre. Para los cristianos es un desafío a servir a todo hombre, como el Señor. "Oh Cristo, tú eres el Rey de la Gloria, tú el Hijo y Palabra del Padre, Tú el rey de toda la creación...Salva a tu pueblo y bendice a tu heredad... Que tu misericordia, Señor, venga sobre nosotros como lo esperamos de ti".

Por último, Señora Presidenta, permítame encomendarla a la protección de la Santísima Virgen, Mujer y Madre, hija de Israel, amada por los musulmanes, venerada por los cristianos como Madre de Dios y madre nuestra: Que Ella, honrada aquí como Virgen del Milagro, la acompañe en esta hora en la que le toca a usted aportar desde el $\underline{\text { lugar de presidenta, lo mejor del genio femenino a la historia de nuestra amada nación. }}{ }^{*}$ Notas:

(1) COMPENDIO DE DOCTRINA SOCIAL DE LA IGLESIA -a partir de ahora CDSI-, No 407.

(2) CEA, La Nación que queremos, 28 de septiembre del 2002, No 5.

(3) Id. 6

(4) CEA, El Compromiso ciudadano y las próximas elecciones, Pilar, 28 de abril de 2007.

\footnotetext{
* Nota: Las secciones de la presente homilía que no se reconocen como discurso religioso o que no corresponden a ninguna etiqueta reconocida como parte del género homilía quedan expresadas en texto subrayado. Elogio al poder político, mención de temas que escapan a la celebración en sí.
} 
140

141 Homilía pronunciada en el Tedeum del 25 de mayo de 2008 por Mons. Mario Antonio 142 Cargnello, arzobispo de Salta, en la iglesia catedral de la ciudad de Salta. 


\title{
1 Homilía Tedeum 25 de mayo de 2009
}

2

3

4

5

6

7

8

\author{
Señora Presidenta de la Nación \\ Señor Gobernador de la provincia de Misiones \\ Señor Intendente de la ciudad de Puerto Iguazú \\ Señores miembros de los Poderes Ejecutivo, Legislativo y Judicial \\ Señores Jefes de las Fuerzas Armadas y de Seguridad \\ Señor Nuncio Apostólico \\ Señores miembros del Cuerpo Diplomático en la Argentina \\ Señores representantes de Instituciones \\ Hermanos y hermanas*
}

La Iglesia católica estuvo comprometida con todos los hechos que significaron el nacimiento de nuestra patria. Incluso antes de la emancipación de España, los valores cristianos impregnaron su vida pública (1), su cultura y sus tradiciones.

La Iglesia, desde los primeros siglos, da gracias a Dios por las bendiciones y beneficios recibidos, por medio de una oración llamada Te Deum. Se trata de un antiguo himno de alabanza que comienza con estas palabras: "Te Deum Laudamos", que significa: "A ti, oh Dios, te alabamos".

Hoy se han reunido aquí las más altas autoridades del país, acompañadas por el cuerpo diplomático de naciones hermanas, ministros y representantes de otros credos y el pueblo de Iguazú. Desde esta casa de oración, desde otras catedrales a lo ancho y largo del país y desde los hogares, nos unimos todos los que creemos en Dios y tenemos una visión trascendente de la vida para dar gracias a Dios, para presentarle nuestra realidad, nuestras necesidades. A Él confiamos nuestro futuro y le pedimos que nos bendiga para que sepamos encontrar los caminos que hagan grande a nuestra patria.

Nos hemos reunido para rezar por la Argentina y por todos los que en ella habitan. San Pablo en su primera carta a Timoteo enseñaba el valor de la oración en común cuando afirmaba: "Ante todo te recomiendo que se hagan peticiones, oraciones, súplicas y acciones de gracias por todos los hombres, por los soberanos y por todas las autoridades para que podamos disfrutar de paz y de tranquilidad" (2). La oración es la prenda de esperanza que elevamos a Dios en todo momento de nuestra historia y de nuestra vida, ya que sabemos que Él nunca abandona a los que en Él se confían. Entonces, hoy nuevamente nos confiamos a Cristo, Señor de nuestra historia y de nuestra vida común, para que nos haga crecer como pueblo, como habitantes, como ciudadanos, como nación.

Esta acción de gracias tiene como marco el tiempo de Pascua, tiempo que siempre es una llamada a renacer de lo alto, de mirar el futuro poniéndonos en las manos de Cristo, muerto y resucitado. La Pascua es tiempo de esperanza y de renovación desde el gozo de Cristo resucitado que nos impulsa a renovar nuestra vocación personal y también nuestra vocación como sociedad. Pascua nos llama a ser profundamente ciudadanos del

\footnotetext{
* Nota: Las secciones de la presente homilía que no se reconocen como discurso religioso o que no corresponden a ninguna

etiqueta reconocida como parte del género homilía quedan expresadas en texto color verde. Elogio al poder político, mención de temas que escapan a la celebración en sí.
} 
cielo pero también ciudadanos de esta tierra, ciudadanos constructores de un nuevo y renovado vínculo social que se encamine al bien común, a la justicia y a la paz que sea capaz de reconstruir con amor y esperanza tanto el orden político como el orden social.

Los obispos argentinos queremos situarnos en la línea de Aparecida que nos llama a ser discípulos y misioneros de Jesucristo en este tiempo de la historia. Somos conscientes de que el mandato de la caridad que nuestro Señor nos manda vivir, alcanza y abraza a todas las dimensiones de la existencia, a todas las personas, a todos los ambientes y a todos los pueblos (3) y nuestra Nación Argentina no escapa a este mandato.

Hoy rememoramos y festejamos un nuevo aniversario del nacimiento de nuestra patria. Fiesta situada providencialmente este año entre la Ascensión del Señor y Pentecostés y a poco tiempo de elecciones nacionales de legisladores. Entonces es bueno dar gracias a Dios por la democracia que entre todos debemos construir y mejorar cada día. Y por eso es bueno reunirse en la iglesia y en todas las comunidades cristianas y que todos los que creemos en Dios agradezcamos juntos el regalo de una patria con una democracia estable que pretende forjar un bien común que pueda beneficiar a todos los hombres y a todos los sectores de la sociedad.

Los inicios de nuestra patria estuvieron signados por valores cristianos y católicos que impregnaron su vida pública y le dieron forma. Es bueno respetar y honrar los orígenes de nuestra cultura siendo fieles a la propia identidad. La patria nació con el sello de Dios y es bueno renovar esta instancia providencial. Esto es justamente lo que pretendemos hacer en cada celebración de una fecha patria. Necesitamos mirar hacia el futuro con esperanza haciendo pie en nuestro presente pero sin olvidar el camino recorrido por los hombres de nuestra patria, sin olvidar la propia historia, nuestras raíces, nuestra cultura.

Jesús, verdadero Dios y verdadero hombre, tuvo una profunda experiencia de amor a su patria, la tierra de sus antepasados. Jesús amaba profundamente a su patria y a su cultura y anhelaba para ella lo mejor. Dice la Escritura que Jesús al contemplar a Jerusalén y sabiendo lo que había de venir, lloró por ella (4). Así también todos los que estamos aquí rezando anhelamos un futuro mejor para nuestra patria. Un futuro en el que haya lugar para la fe en Dios, para la educación, la salud, la inclusión de sus habitantes, en el que se pueda trabajar más y mejor y en el que sean importantes los derechos y los deberes de los ciudadanos.

Quiera Dios que el proyecto de vida político, económico y social que seamos capaces de delinear nos lleve a fortalecer nuestra joven democracia. Que sepamos encontrar las respuestas adecuadas para salir de la profunda crisis moral -que es la raíz de muchos males culturales y sociales presentes en este mundo globalizado- que hoy nos afecta también a nosotros. No obstante la crisis moral global que nos incluye, nuestra mirada es esperanzada y esperanzadora. Creemos estar ante una oportunidad única. Podemos aprovecharla, privilegiando la construcción del bien común, o malgastarla con nuestros intereses egoístas y posturas intransigentes que nos fragmentan y dividen (5).

Por eso debe ser exigencia para todos nosotros: obispos, gobernantes y miembros de la comunidad con alguna responsabilidad pública el sentirnos responsables por el bien general superando las diferencias que nos enfrentan, buscando la reconciliación y aportando todas nuestras energías para "construir el bien común, el bien sectorial y el 
96 bien personal, buscando una fórmula de convivencia y desarrollo de la pluralidad dentro

97 de la unidad de objetivos fundamentales» (6).

98

99 Pidamos a Dios en este día de alabanza con sinceridad de corazón que nos haga 100 ciudadanos de esta tierra pero también ciudadanos del cielo, para que la fe, la esperanza

101 y el amor contenidos en los Evangelios abra en nuestros corazones un camino y una luz 102 nueva y esperanzadora que nos lleve a privilegiar la construcción del bien común de 103 nuestra patria (7).

104

105 Que María, madre del Verbo Eterno y Madre de Jesús de Nazaret nos ayude en este 106 camino de construir nuestro destino de patria y de nación.

107

\section{REFERENCIAS}

109

110 HB: Hacia el Bicentenario en justicia y solidaridad. CEA 96 Asamblea Plenaria de 111 Obispos

112 (1) HB número 9

113 (2) 1 Tim. 2,1-2

114 (3) HB número 1

115 (4) Cfr. Lc. 19,41

116 (5) HB número 12

117 (6) HB número 13

118 (7) HB número 12

119

120 Homilía de monseñor Marcelo Raúl Martorell, obispo de Puerto Iguazú con motivo de 121 conmemorarse la fiesta patria del 25 de mayo (25 de mayo de 2009) 


\section{Homilía Tedeum 25 de mayo de 2010 Luján}

3 Señora Presidenta de la Nación Dra. Cristina Fernández de Kirchner,

4 Excelentísimos Señores Presidentes de países amigos,

5 Su Excelencia Reverendísima Señor Nuncio Apostólico, Enviado Extraordinario de Su

6 Santidad Benedicto XVI en Misión Especial para participar en los Actos Centrales de la

7 Conmemoración de la Revolución de Mayo,

8 Queridos hermanos en el Señor.

9 Al comenzar esta reflexión con ocasión del acontecimiento histórico para nuestra patria

10 que conmemora los 200 años de su nacimiento, entre este 25 de mayo de 2010 y el 9 de

11 julio de 2016, quiero dar un saludo especial a todos los presentes y a aquellos que nos

12 siguen por cadena nacional, de parte de mis hermanos obispos, que desde todas las

13 catedrales de la Argentina, dan gracias a Dios por este aniversario.

14 Llegamos con gratitud y emoción a este templo, cobijo maternal de todos los argentinos 15 para celebrar el solemne Te Deum.

16 Queremos ver nuestra historia desde la fe, con sus luces y sus sombras, sus angustias y 17 esperanzas. Mientras sufrimos y nos alegramos, permanecemos en el amor de Cristo, 18 mirando nuestro mundo...(1)

19 El magno aniversario que nos convoca no nos impide estar preocupados por algunos 20 signos de deterioro de nuestro acervo cultural, heredado de los padres de la Patria, que 21 han hecho de nuestro pueblo ciudadanos convencidos de aquellos valores que dignifican la persona humana. Toda legislación, presente o futura, deberá promover la defensa de la vida, la familia y el bien común. No son estos aspectos conflictivos los que nos ocupan y hoy reclaman nuestra atención, sino aportar desde nuestra identidad y, ante los desafíos de este nuevo siglo, algunas líneas para proyectar el futuro con dignidad. Buscando iluminar la celebración del Bicentenario como oportunidad de crecimiento, plantearé cuatro dimensiones: memoria, identidad, reconciliación y desafíos.

\section{Memoria}

Hoy llegamos para rezar, para unirnos en esta oración privilegiada de alabanza que ha acompañado la vida de la iglesia y de los pueblos cristianos desde hace mas de 1600 años - esta es la antigüedad que tiene la oración del Te Deum- . Nuestra Patria también ha recurrido a ella aquél 25 de mayo de 1810, donde los cabildantes profirieron el primer grito de libertad, que llegaría a su formalización y federalización cuando las Provincias Unidas de la América del Sud se reunieran en San Miguel de Tucumán para proclamar la Independencia el 9 de julio de 1816.

Un dato que quiero destacar es que a los pocos días de constituida la Junta de mayo, la cual asumiera la soberanía correspondiente al pueblo por la ausencia del rey de España, tomado prisionero por las tropas napoleónicas, también el cabildo de Luján, precisamente el 17 de junio, mandó oficiar un Te Deum, ante esta misma imagen de Nuestra Señora, por la instalación del primer gobierno patrio (2) y hoy aquí, dos siglos después, a Ella nos volvemos a confiar. mezquindades y, bajo este punto de vista decimos que El ha conducido la historia. Nuestro Dios, "fuente de toda razón y justicia", como expresa el preámbulo de nuestra constitución, nos ha ayudado paternalmente a caminar, a progresar, a organizarnos, a 
superar conflictos, a abrazar los ideales democráticos, a recibir en nuestro suelo a todos los "hombres de buena voluntad", a cultivar el espíritu de tolerancia, a promover los amplios y variados caminos de la promoción humana.

Por tanto, damos gracias a Dios por la vida de todos nuestros hermanos que habitan este bendito suelo. Riquezas humanas en las diversas razas, desde los aborígenes hasta las diferentes corrientes migratorias. Y gracias también por las riquezas naturales con que hemos sido beneficiados por el Creador en nuestro vasto territorio.

\section{Identidad}

Los obispos argentinos decíamos en 2008 “Desde los inicios de nuestra comunidad nacional, aun antes de la emancipación, los valores cristianos impregnaron la vida pública. Esos valores se unieron a la sabiduría de los pueblos originarios y se enriquecieron con las sucesivas inmigraciones. Así se formó la compleja cultura que nos caracteriza.(...) En nuestra cultura prevalecen valores fundamentales como la fe, la amistad, el amor por la vida, la búsqueda del respeto a la dignidad del varón y la mujer, el espíritu de libertad, la solidaridad, el interés por los pertinentes reclamos ante la justicia, la educación de los hijos, el aprecio por la familia, el amor a la tierra, la sensibilidad hacia el medio ambiente, y ese ingenio popular que no baja los brazos para resolver solidariamente las situaciones duras de la vida cotidiana. Estos valores tienen su origen en Dios y son fundamentos sólidos y verdaderos sobre los cuales podemos avanzar hacia un nuevo proyecto de Nación, que haga posible un justo y solidario desarrollo de la Argentina. (3)

Los mencionados valores, que cimientan nuestra identidad han sido heroicamente vividos por quienes nos dieron independencia y libertad y trazaron sendas para hacer grande y noble nuestra nación. Como ejemplo baste mencionar a dos de nuestros mayores próceres como lo son el General Manuel Belgrano, de profundas convicciones cristianas, el cual pasara en septiembre de 1810 por este santuario y mandase celebrar una misa solemne en honor de la Virgen pidiendo la protección del Señor ante las campañas emprendidas. También el libertador don José de San Martín, desde el año 1813 fue acompañado hasta el final de sus batallas en 1823, por un relicario de Nuestra Señora de Luján.

La posibilidad de convivir en paz aborígenes, mestizos, e inmigrantes que habitan nuestro querido suelo y, hoy conforman la rica amalgama que nos identifica, también la hemos de colocar entre los agradecimientos. Se logró así una cultura, entendiendo por ella el modo de vida de un pueblo, abarcando todos los aspectos: los valores que lo animan y los desvalores que lo debilitan (4).

\section{Reconciliación}

En este momento crucial debemos estar empeñados por defender a cualquier costo el bien común y la unidad nacional.

Si somos humildes, hemos de hacer nuestra súplica de perdón al Padre de todos por los errores cometidos, por tantos egoísmos que nos llevaron a tremendas luchas fratricidas, desde los inicios de nuestra nacionalidad. Convencidos de la fragilidad de la condición humana, no nos excluimos, como Iglesia de las miserias, aunque la fe en Cristo nos anima y nos hace misericordiosos, ya que el perdón que ofrecemos al prójimo nos obtiene el perdón de Dios (5).

Esa misma fe en Cristo, Señor del mundo y de la historia, nos anima en la esperanza de lograr acá, en este mundo, una mayor transparencia de su luz: suplicamos por una justicia más efectiva, por una mejor y más equitativa distribución de la riqueza, por una mayor independencia de los poderes republicanos. Es una tarea que hacemos todos, 
contando con la imprescindible ayuda del Señor. Decíamos los obispos en marzo de este año: "La Patria es un don que hemos recibido, la Nación una tarea que nos convoca y compromete nuestro esfuerzo. Asumir esta misión con espíritu fraterno y solidario es el mejor modo de celebrar el Bicentenario de nuestra Patria" (6).

\section{Desafíos}

La historia es maestra de la vida decía Cicerón. Aprendamos de nuestras crisis, hagamos de nuestros desencuentros una oportunidad de crecimiento. De nada sirve llorar sobre las cenizas. Nunca ha ayudado la falta de esperanza. Solo se puede crecer en la comunión y el amor recíproco.

Debemos afirmar, que el bicentenario es un desafío insoslayable para la democracia argentina. El bicentenario, interpela, interroga, reclama soluciones, estimula a elaborar proyectos políticos, a presentar propuestas sociales y culturales, a mejorar la calidad de nuestras instituciones. Acá se pone en juego nuestra capacidad de ser Nación, que como rezamos en la conocida oración por la Patria, "una Nación cuya identidad sea la pasión por la verdad y el compromiso por el bien común."

Estamos ante una oportunidad única, ya sea a nivel mundial, donde la llamada globalización nos desafía a no perder nuestra identidad ni replegarnos sobre nosotros mismos. Se trata de enriquecernos dándonos. También es una ocasión propicia y hasta necesaria para una mayor integración al continente, a la América latina que conforman nuestros hermanos más cercanos: la patria grande soñada por San Martín y por Bolívar. Como argentinos y argentinas nos debemos un mayor desarrollo federal, sano y armónico. Llevamos transitados el mayor período en régimen democrático de nuestra historia y son apenas 27 años. Hemos de promover, como dice el papa Benedicto "una mayor fidelidad a la democracia, ya que es la única que puede garantizar la igualdad y los derechos de todos" (7). Se trata, explica más adelante en el mismo discurso, de una democracia con valores, es decir que busque la verdad y se pruebe en la justicia. El desafío de una educación para todos y que, como decía el gran educador de la juventud San Juan Bosco tenga por finalidad lograr "honestos ciudadanos y buenos cristianos". Otro desafío impostergable será saldar nuestra deuda con los pueblos originarios. Ambas tareas nos permitirán construir nuestro futuro en paz y prosperidad. Nos debemos un diálogo magnánimo y sereno, que significa abrirnos camino a través de la palabra y para eso debemos escucharnos con respeto y fortalecer el consenso sobre referencias comunes y constantes, más allá de partidismos e intereses personales. No será tarea fácil incluir a todos, promover la igualdad y el desarrollo social, sin "sobrantes" como dice el documento de Aparecida, aunque también sabemos que sin la presencia y ayuda divina esto es imposible, ya que la mayor pobreza es la de no reconocer la presencia del Misterio de Dios y de su amor en la vida del hombre (8). Al concluir, queridos hermanos, permítanme dirigir mi oración al Señor por intercesión de su Santísima Madre:

En el bicentenario que comenzamos a celebrar nos ponemos una vez en tus manos María de Luján, para que nos alcances de tu Hijo Jesús la fortaleza y la sabiduría que nos encaminen decididamente hacia la Patria de hermanos que soñamos.

Por eso te pedimos nos concedas Señor:

Humildad para poder servirte en los pobres.

Esperanza para superar las dificultades.

Paciencia para saber construir con generosidad y alegría.

Hambre y sed de justicia para trabajar por un mundo nuevo.

Misericordia para sabernos perdonados. 
142 Un corazón puro para descubrirte en todos.

143 Ser artesanos de la paz en cada día de nuestra vida.

144 En una palabra, no avergonzarnos nunca de creer en Ti y vivir con coherencia el

145 Evangelio.

146 Jesucristo Señor de la historia, te necesitamos. Sé nuestro Pastor y guíanos siempre.

147 Amén.

148 Notas:

149 (1) V Conferencia Episcopal Latinoamericana, Documento de Aparecida, Buenos Aires, $150 \quad 2007, \mathrm{n}^{\circ} 22$

151 (2) Vicente Sierra, Historia de la Argentina, Buenos Aires, 1962, tomo V, pg. 61.

152 (3) Conferencia Episcopal Argentina, Hacia un bicentenario en justicia y solidaridad,

$15396^{\circ}$ Asamblea Plenaria, noviembre de 2008, $\mathrm{n}^{\circ} 9-10$.

154 (4) III Conferencia Episcopal Latinoamericana, Documento de Puebla, Buenos Aires, $1551979, \mathrm{n}^{\circ} 387$

156 (5) Cfr. Padre Nuestro.

157 (6) Conferencia Episcopal Argentina, $155^{\circ}$ Reunión Comisión Permanente, 10 de marzo 158 de $2010, \mathrm{n}^{\circ} 4$

159 (7) Cfr. Benedicto XVI, Discurso a las asociaciones cristianas de trabajadores italianos, 16027 de enero de 2006.

161 (8) V Conferencia Episcopal Latinoamericana, Documento de Aparecida, Buenos Aires, $1622007, \mathrm{n}^{\circ} 405$.

163 Mensaje de monseñor Agustín Radrizzani, arzobispo de Mercedes-Luján en el Te Deum 164 por el Bicentenario (25 de mayo de 2010) 